\author{
Universidade de São Paulo \\ Instituto de Física \\ Instituto de Química \\ Instituto de Biociências \\ Faculdade de Educação
}

\title{
PROQUIM em ação: ressignificando o conceito de transformação no Ensino Médio
}

\author{
Michele Marcelo Silva Bortolai
}

Orientador: $\operatorname{Prof}^{\mathrm{a}} \mathrm{Dr}^{\mathrm{a}}$ Daisy de Brito Rezende

Dissertação de mestrado apresentada aos Instituto de Física, ao Instituto de Química, ao Instituo de Biociências e a Faculdade de Educação da Universidade de São Paulo, para a obtenção do título de Mestre em Ensino de Ciências. 
MICHELE MARCELO SILVA BORTOLAI

\section{PROQUIM em ação: ressignificando o conceito de transformação no Ensino Médio}

Dissertação de Mestrado apresentada aos Institutos de Física, Química, Biociências e à Faculdade de Educação da Universidade de São Paulo, para a obtenção do título de Mestre em Ensino de Ciências.

Área de concentração: Ensino de Química

Orientador: $\operatorname{Prof}^{\mathrm{a}} \operatorname{Dr}^{\mathrm{a}}$ Daisy de Brito Rezende

São Paulo

2010 
Autorizo a reprodução e divulgação total ou parcial deste trabalho, por qualquer meio convencional ou eletrônico, para fins de estudo e pesquisa, desde que citada a fonte.

\section{FICHA CATALOGRÁFICA \\ Preparada pelo Serviço de Biblioteca e Informação do Instituto de Física da Universidade de São Paulo}

Bortolai, Michele Marcelo Silva

Proquim em ação: ressignificando o conceito de transformação no Ensino Médio - São Paulo, 2009.

Dissertação (Mestrado) - Universidade de São Paulo. Faculdade de Educação, Instituto de Física, Instituto de Química e Instituto de Biociências

Orientador: Profa. Dra. Daisy de Brito Rezende

Área de Concentração: Ensino de Química

Unitermos: 1. Química - Estudo e ensino; 2. Ensino e aprendizagem; 3. Química - Conceitos; 4. Construção do conhecimento.

USP/IF/SBI-090/2009 
Nome: BORTOLAI, Michele Marcelo Silva

Título: PROQUIM em ação: ressignificando o conceito de transformação no Ensino Médio.

Dissertação de Mestrado apresentada aos Institutos de Física, Química, Biociências e à Faculdade de Educação da Universidade de São Paulo, para a obtenção do título de Mestre em Ensino de Ciências.

Aprovado em: $\quad 04$ de março de 2010.

\section{Banca Examinadora}

Prof. Dr. Flavio Antonio Maximiano

Profa. Dra. Glaucia Maria da Silva

Profa. Dra. Daisy de Brito Rezende
Instituição: Universidade de São Paulo

Instituição: Universidade de São Paulo

Instituição: Universidade de São Paulo 
À minha família, com amor, admiração e gratidão por sua compreensão, carinho, presença e incansável apoio ao longo do período de elaboração deste trabalho. 


\section{AGRADECIMENTOS}

Ao meu esposo Geraldo que, com muito carinho e dedicação, muito me ensinou, contribuindo para meu crescimento científico e intelectual.

À Prof ${ }^{\mathrm{a}}$. Dr ${ }^{\mathrm{a}}$. Daisy de Brito Rezende, pela atenção e apoio durante o processo de definição e orientação de meu trabalho.

Aos alunos da Escola Estadual Professora Irene Branco da Silva, pela contribuição à realização desta pesquisa.

À minha amiga Mari Inês Tavares pela ajuda e paciência em ler meus textos e corrigilos. 


\section{RESUMO}

\section{BORTOLAI, M. M. S. PROQUIM em ação: ressignificando o conceito de transformação no Ensino Médio. 2010. 272 p. Dissertação (Mestrado) - Universidade de São Paulo. 2010.}

Esta Dissertação tem por objetivo analisar a ressignificação do conceito de transformação presente na estrutura cognitiva dos educandos de primeiro ano de Ensino Médio, de uma escola da rede pública estadual da cidade de São Paulo, sendo 53 alunos do ano de 2006 e 83 alunos do ano de 2007. Para tanto, o elemento norteador das atividades propostas para coleta de dados, foi o material instrucional intitulado PROQUIM, desenvolvido na década de 1980, conforme as teorias construtivistas. $\mathrm{O}$ mesmo foi utilizado porque promove a construção do conhecimento a partir de atividades desenvolvidas individual e coletivamente, possibilitando ao professor a mediação entre o conhecimento já instituído e a construção do conhecimento escolar, onde é sabido da existência de relações colaborativas entre educandos e educadores. Assim, para atingir o objetivo proposto nesta investigação de abordagem qualitativa, a pesquisadora observou por meio do método dialético que as relações dialógicas mantidas entre educandos e educadores influenciaram os processos de ensino e aprendizagem, facilitando a inclusão de novos atributos ao conceito que estava sendo referenciado, promovendo assim, o desenvolvimento de ações mais reflexivas para a resolução de situações propostas. Deste modo, as atividades que foram sendo apresentadas aos alunos partiram da existência de um conhecimento mais abrangente, para o estabelecimento de conceitos mais específicos. Portanto, estes adolescentes foram expostos a conflitos cognitivos, em suas zonas de desenvolvimento proximal, estabelecendo uma relação colaborativa entre seus pares e a professora na procura pela construção do conceito verdadeiro. A formação do conceito na estrutura cognitiva passa por diversas etapas até o estabelecimento de sua concepção, ou seja, quando o conceito ainda não está estabilizado no pensamento, o sujeito procura observar, macroscopicamente, as características do objeto sob estudo para depois poder atribuir-lhe características mais específicas. Com efeito, estes conflitos cognitivos permitiram que a pesquisadora observasse as mensagens dos educandos, que expressavam suas concepções a respeito do conceito de transformação e sua crescente modificação através das relações colaborativas ocasionadas pela busca do conhecimento.

Desta análise conclui-se que parte dos educandos conseguiu estabelecer relações distinguíveis entre os aspectos dos sistemas sob processo de transformação, antes e após a modificação ter-se sucedido. Outra parte dos educandos demonstrou a necessidade de outros contextos de aprendizagem, a fim de favorecer o estabelecimento em suas estruturas cognitivas, do conceito de transformação dos materiais.

Palavras-chave: ensino e aprendizagem, conceitos, transformação. 


\begin{abstract}
BORTOLAI, M. M. S. PROQUIM in action: giving new meaning to the concept of transformation in high school. 2010. 272 p. Thesis (MA) - University of Sao Paulo. 2010.

This thesis aims to analyze the reclassification of the concept of this processing in the cognitive structure of students of first year of high school, a public school in the state of São Paulo, with 53 students in 2006 and 83 students from years 2007. To this end, the guiding element of the proposed activities for data collection, was the instructional material titled PROQUIM, developed in the 1980s, as constructivist theories. It was used because it promotes the construction of knowledge from activities carried out collectively and individually, allowing the teacher to mediate between the knowledge already established and the construction of school knowledge, which is known of the existence of collaborative relationships between educators and students. So to achieve this goal, this research a qualitative approach, the researcher observed through the dialectical method that kept the dialogical relations between educators and influence the processes of teaching and learning by facilitating the inclusion of new attributes to the concept that was being referenced thus promoting the development of more reflexive actions to resolve situations proposed. Thus, activities that were being presented to students from the existence of a more comprehensive, for the establishment of more specific concepts. Therefore, these adolescents were exposed to cognitive conflicts in their zones of proximal development, establishing a collaborative relationship between peers and the teacher in finding the true construction of the concept. The formation of the concept in cognitive structure goes through several stages until the establishment of its design, ie, when the concept is not yet stable in thought, the subject tries to observe macroscopically, the characteristics of the object under study to be allowed to assign specific characteristics. Indeed, these cognitive conflicts enabled the researcher observed the students' messages, expressing their views about the concept of transformation and change through its growing collaborative relationships caused by the pursuit of knowledge.
\end{abstract}

From this analysis it appears that some of the students managed to establish relations between distinguishable aspects of systems in the transformation process, before and after the change have been successful. Another part of the students demonstrated the need for other learning contexts to promote the establishment of cognitive structures, the concept of transformation of materials.

Keywords: teaching and learning, concepts, transformation. 


\section{LISTA DE FIGURAS}

Figura 3.1 Apresentação dos conceitos introduzidos pelo PROQUIM 64

Figura 4.1 Mapa da disposição física do laboratório de Química 78

$\begin{array}{lll}\text { Figura 4.2 Vista frontal } 1 \text { do laboratório } & 79\end{array}$

$\begin{array}{lll}\text { Figura 4.3 Vista frontal } 2 \text { do laboratório } & 79\end{array}$

Figura 4.4 Vista das bancadas do laboratório $\quad 80$

Figura 4.5 Momento de interação professora-aluno $\quad 81$

Figura 4.6 Momento de interação aluno-aluno $\quad 81$

Figura 4.7 Categorias e Subcategorias para análise da formação do conceito de transformação

Figura 4.8 Subcategorias de análise das proposições dos alunos para a categoria amontoados sincréticos, no âmbito macroscópico das observações.

Figura 5.1 Conceitos a serem ressignificados na estrutura cognitiva dos educandos, partindo de um conceito mais abrangente para um conceito mais específico.

$\begin{array}{lll}\text { Figura 5.2 Evocações referentes a refrigerante e cerveja } & 104\end{array}$

$\begin{array}{lll}\text { Figura 5.3 Evocação referente a unhas } & 105\end{array}$

Figura 5.4 Evocações referentes a milho de pipoca 105

$\begin{array}{lll}\text { Figura 5.5 Evocações referentes a gelatina } & 106\end{array}$

$\begin{array}{lll}\text { Figura 5.6 } & \text { Evocações referentes a ar } & 107\end{array}$

$\begin{array}{lll}\text { Figura 5.7 Evocações referentes a fezes e urina } & 107\end{array}$

$\begin{array}{lll}\text { Figura 5.8 } & \text { Evocações referentes a leite e queijo } & 108\end{array}$

Figura 5.9 Evocações referentes ao processo de desenvolvimento das plantas 109

Figura 5.10 Evocações referentes ao processo de fermentação 110

Figura 5.11 Evocações referentes a café e leite, água e suco em pó, barro + água e detergente ou sabão em pó

Figura 5.12 Evocações referentes a sol e dia

Figura 5.13 Evocações referentes a dentes e café 112

Figura 5.14 Evocações referentes a decomposição 114

Figura 5.15 Algumas justificativas de reconhecimento da reação química, mencionadas por alunos do ano letivo de $2006 \quad 118$

Figura 5.16 Algumas justificativas de reconhecimento da reação química classificadas na subcategoria "Conceitos Potenciais" 
Figura 5.17 Exemplos de respostas classificadas na categoria Amontoados Sincréticos

Figura 5.18 Outros exemplos de justificativas classificadas na categoria Amontoados Sincréticos

Figura 5.19 Exemplos de respostas classificadas na categoria Pensamento Conceitual

Figura 5.20 Tabela Individual do aluno Alex_2006

Figura 5.21 Tabela Individual do aluno Carlos_2007

Figura 5.22 Tabela Individual da aluna Elena_2007

Figura 5.23 Resposta do aluno Alex_2006 para a terceira atividade

Figura 5.24 Resposta do aluno Carlos_2007 para a terceira e quarta atividades

Figura 5.25 Resposta da aluna Elena_2007 para a terceira e quarta atividades 


\section{LISTA DE QUADROS}

Quadro 3.1 Habilidades a serem desenvolvidas pelos alunos através das situações de aprendizagem apresentadas pelo PROQUIM (1986) 73 e pelo CADERNO DO PROFESSOR - PCN (2008)

Quadro 4.1 Questionário enviado aos idealizadores e escritores do PROQUIM. 


\section{LISTA DE TABELAS}

Tabela 2.1 Fases de ordenação do pensamento para formação de conceitos, conforme proposto por VIGOTSKI (2005)

Tabela 3.1 Fases de estudo do capítulo 1 do PROQUIM

Tabela 3.2 Fases de estudo do capítulo 2 do PROQUIM

Tabela 3.3

Organização de conceitos introduzidos pelo PROQUIM (1986) e pelo Caderno do Professor - PCN (2008)

Tabela 4.1 Atividades selecionadas como fonte de coleta de dados

Tabela 4.2 Atividades solicitadas para observação de concepções prévias

Tabela 5.1

Tabela 5.2

Tabela 5.3

Tabela 5.4

Tabela 5.5

Tabela 5.6

Tabela 5.7

Tabela 5.8

Quantidade de evocações construídas individualmente nos anos de 2006 e 2007

Quantidade de evocações apresentadas coletivamente pelas turmas participantes da pesquisa.

Etapas de formação do conceito de transformação, utilizando sistemas apresentados nas Tabelas Individuais na primeira e segunda atividades.

Comparação entre os dados coletados nas Tabelas Individual e Coletiva dos alunos do ano de 2006

Comparação entre os dados coletados nas Tabelas Individual e Coletiva dos alunos do ano de 2007.

Etapas de formação do conceito de transformação para a terceira atividade

Etapas de formação do conceito de transformação para a quarta atividade

Comparação entre as etapas de formação do conceito de transformação e as atividades propostas para análise 


\section{SUMÁRIO}

1 CONTEXTO E OBJETIVO DA PESQUISA 15

1.1 O contexto da realização desta pesquisa científica 16

$\begin{array}{lll}1.2 & \text { Objetivos } & 18\end{array}$

2 AS RELAÇÕES COLABORATIVAS E O PROCESSO DE CONSTRUÇÃO DO CONHECIMENTO ESCOLAR

Vigotski e a dimensão cognitiva do desenvolvimento humano no espaço da educação escolar

A zona de desenvolvimento proximal como instrumento de construção do

2.2 pensamento: o uso de símbolos e a prática da ação colaborativa durante as etapas da formação de conceitos

2.3 A prática da ação colaborativa na construção do conhecimento escolar durante o processo de formação dos conceitos.

O conhecimento Químico no contexto da educação escolar: a

2.4 experimentação como motivadora ao desenvolvimento de conceitos científicos

A socialização do saber e o desenvolvimento intelectual dos sujeitos

2.5 envolvidos nos processos de ensino e aprendizagem: o professor e o cotidiano escolar para a construção do conhecimento científico

3 O PROQUIM COMO MATERIAL INSTRUCIONAL

3.1 O PROQUIM e a Teoria da Aprendizagem Significativa de David Ausubel 56

3.2 Descrição do Material instrucional $\quad 61$

3.3 O PROQUIM e a Proposta Curricular para o ensino de Química no Estado de São Paulo em 2008

4 METODOLOGIA $\quad 75$

4.1 Caracterização da pesquisa $\quad 76$

4.1.1 Abordagem 76

4.1.2 Público-alvo 76

4.1.3 O método e a caracterização do ambiente de pesquisa 77

4.1.4 O material didático $\quad 82$

4.2 Coleta de dados $\quad 83$

4.2.1 As aulas de Química e as atividades selecionadas como fonte de dados $\quad 84$

4.2.1.1 Aplicação: $1^{\underline{a}}$ e $2^{\underline{a}}$ atividades selecionadas como fonte de coleta dados 86 
4.2.1.2 Aplicação: $3^{\mathrm{a}}$ e $4^{\mathrm{a}}$ atividades selecionadas como fonte de coleta dados

4.2.2 Questionamentos aos escritores do material instrucional 89

$\begin{array}{lll}4.3 & \text { Análise de dados } & 89\end{array}$

$5 \quad$ RESULTADOS E DISCUSSÃO $\quad 94$

5.1 Análise dos dados referentes à ressignificação do conceito de 95

5.1.1 Análise da primeira e segunda atividades 97

$\begin{array}{lll}\text { 5.1.2. } & \text { Análise da terceira atividade } & 117\end{array}$

$\begin{array}{lll}\text { 5.1.3 } & \text { Análise da quarta atividade } & 121\end{array}$

5.2 Comparação entre as etapas de formação do conceito de transformação nas 126

5.3 Análise dos dados apresentados por três estudantes participantes da $\quad 130$ pesquisa

5.3.1 Análise da primeira atividade realizada por Alex_2006, Carlos_2007 e Elena_2007

5.3.2 Análise da terceira atividade realizada por Alex_2006, Carlos_2007 e Elena_2007

5.3.3 Análise da quarta atividade realizada por Alex_2006, Carlos_2007 e Elena_2007

6 CONCLUSÕES

6.1 Conclusões 141

REFERÊNCIAS $\quad 144$

$\begin{array}{ll}\text { ANEXOS } & 158\end{array}$ 


\section{Capítulo 1}

\section{Contexto e Objetivo da Pesquisa}

“(...) a interação do agente e do fenômeno social é permeada por um emaranhado de conceitos e significados construídos socialmente (...)" (sILVA et al., 2005, p. 70) 


\subsection{O contexto da realização desta pesquisa científica}

Quando iniciei o curso de Pós Graduação em Ensino de Ciências na Universidade de São Paulo, no ano de 2006, me senti muito constrangida em falar sobre minhas dificuldades, enquanto professora, perante os outros colegas que cursavam o mesmo curso que eu. Entretanto, logo percebi que muitos compartilhavam da mesma angústia e enfrentavam os mesmos problemas encontrados por mim no ambiente escolar.

Minha inquietação se estabelecia em torno do desinteresse de meus alunos, quanto à aprendizagem de Química. Os alunos a que me refiro eram todos de Ensino Médio de uma escola pública Estadual da região leste da cidade de São Paulo, escola na qual sou professora efetiva desde o ano de 2005. Apesar de minha efetivação como professora nesse sistema de ensino ter ocorrido nessa época, eu já era professora dessa área desde 1993.

Minha proposta inicial era trabalhar com a construção de um material didático inovador para o ensino de Química e mais apropriado à realidade desses educandos, que têm apenas duas aulas semanais desta disciplina, o que em minha opinião é insuficiente para a construção de um conhecimento realmente significativo.

Foi nesse momento que conheci minha orientadora e perguntei sobre seu interesse em orientar meus trabalhos de pesquisa nesta Universidade. Nessa entrevista inicial, a Profa. Dra. Daisy de Brito Rezende me apresentou um material instrucional de nome PROQUIM $^{1}$, que vinha ao encontro de minhas expectativas para com a melhoria do ensino de Química, pois apresenta o conteúdo articulado a procedimentos experimentais, o que poderia ser mais um facilitador da construção do próprio conhecimento, pois contextualiza o conteúdo ao cotidiano dos educandos.

Como o tempo para o prosseguimento da pesquisa investigativa é um tempo limitado resolvemos, então, aplicar somente o capítulo 1 do material para os alunos de $1^{\circ}$ ano do Ensino Médio, visto que o conteúdo ali apresentado vai ao encontro das atuais Propostas Curriculares para o Ensino de Química do Estado de São Paulo (BRASIL, 1999).

Diante do proposto no PROQUIM ${ }^{2}$ e a atual visão de ensino de Química brasileiro, que procura articular "(...) teoria e prática (...)" (TREVISAN \& MARTINS, 2006, p. 4) resolvemos,

\footnotetext{
${ }^{1}$ Equipe de colaboradores do PROQUIM: Antonieta Bianchi Mazon, Daisy de Brito Rezende, Lilavate Izapovits Romanelli, Maria Eunice Ribeiro Marcondes, Maria Helena Roxo Beltran, Nelson Orlando Beltran, Roseli Pacheco Schenetzler.

${ }^{2} \mathrm{O}$ capítulo 3 se refere aos princípios metodológicos e conteúdo curricular do material instrucional.
} 
então, audaciosamente, investir em uma proposta inovadora para mim, que estava acostumada com uma aula sem a aplicação de procedimentos experimentais, como meio de observação e ressignificação do conhecimento ao mesmo tempo que, coletiva, também singular.

Antes de iniciar a utilização do material, percebia que meus alunos não tinham interesse em participar de minhas aulas. Talvez, por essas não apresentarem processos que lhes permitissem lidar com o que fosse novo e significativo, ou por eu mesma perceber e deixar transparecer que já não estava mais satisfeita com a aula desinteressante que vinha oferecendo. Assim, comecei a pesquisar e notei que a educação vem sofrendo mudanças significativas em sua concepção e métodos, de maneira que se tem almejado, no âmbito acadêmico, buscar alternativas para um modelo de educação que se desenvolva de forma a superar as características tradicionais que marcaram o ensino nas últimas décadas (PONTES, et al., 2008; TREVISAN \& MARTINS, 2006).

Ao tomar contato com os autores que fundamentaram minha pesquisa, observei que todos encaminhavam suas reflexões a partir de uma linha de pensamento que aponta em direção a uma concepção de educação que pressupõe a prática da ação colaborativa entre professores e educandos. Dessa ação, se realizaria a construção coletiva do conhecimento e desenvolvimento da linguagem, utilizada por ambos os sujeitos do processo de ensino e aprendizagem.

Também, a prática de procedimentos experimentais, como meio que permite aos educandos observar o acontecimento dos fenômenos, é defendida pelos autores presentes nesta Dissertação, pois compartilham da idéia de que quando se pode construir o conhecimento, a partir do que the é comum, torna-se mais fácil para os alunos ressignificarem o que já conhecem, ampliando o repertório de informações peculiares a cada um. Assim, o PROQUIM - material instrucional desenvolvido conforme a teoria construtivista - compôs a orientação para o desenvolvimento desta investigação, na qual a prática docente da professora-pesquisadora se referenciou na teoria sócio-construtivista para orientar a busca de informações que servirão para responder as questões investigativas aqui propostas.

O PROQUIM apresenta um rol de atividades que estimulam o processo investigativo motivando os educandos a construírem o próprio conhecimento. O PROQUIM também apresenta questões que exigem a formação de novos conceitos através da mobilização das informações que os alunos já possuem. Esses conceitos irão adquirir novos significados porque outros atributos lhe serão conferidos, ressignificando a cada momento o signo já presente no curso de suas operações mentais. Para tanto, é importante considerar a 
relevância da relação entre professores e alunos com o conteúdo a ser apreendido, que neste caso apóia-se em uma metodologia de construção coletiva do conhecimento por meio da colaboração entre os pares, sendo este "(...) um fator importante para o surgimento do pensamento intelectual (VIGOTSKI, 2005, p. 73)”.

Logo, proponho-me a analisar a ressignificação de um conceito proveniente do saber comum, e que está presente na estrutura cognitiva dos educandos, público-alvo desta pesquisa. O conceito a que me refiro é o de transformação e que será analisado a partir de expressões presentes em atividades procedentes do PROQUIM, as quais se desenvolveram de forma individual e também coletiva, em um ambiente escolar adequado à realização de experimentos.

\subsection{Objetivo}

O objetivo desta pesquisa é observar se os processos de ensino e aprendizagem de conceitos químicos influenciam a ressignificação do conceito de transformação. Para tanto, pretende-se analisar a modificação das concepções dos educandos acerca dos processos de transformações dos materiais. Assim, de um modo geral, procuramos responder às seguintes questões:

1. Situações de aprendizagem realizadas mediante relações colaborativas facilitam a ressignificação do conceito de transformação?

2. É possível reconhecer a modificação na concepção do conceito de transformação para transformação química a partir de atividades existentes no PROQUIM e realizadas colaborativamente?

Deste modo, para responder a estas questões a Dissertação está dividida em seis capítulos, que nortearão o desenvolvimento e análise dos dados obtidos no processo investigativo realizado com alunos de primeiro ano do Ensino Médio.

No Capítulo 1, está descrito os motivos que levaram a pesquisadora a desenvolver este projeto de pesquisa e o ambiente no qual ele foi realizado.

O Capítulo 2 relata as etapas de formação de conceitos na estrutura cognitiva dos adolescentes quando são expostos a conflitos cognitivos em sua zona de desenvolvimento proximal. Apresenta, também, as características peculiares aos adolescentes quando se reportam ao relacionamento existente entre educandos e educadores em um processo 
colaborativo de construção de conhecimento. Neste mesmo capítulo nos reportamos à vários autores que realizaram processos investigativos com educandos e educadores da Educação Básica. A maioria dos relatos encontrados apresenta aspectos que levam os alunos a se interessarem pelo conhecimento de conceitos científicos e os relacionarem com o seu cotidiano. Também neste capítulo está descrito os motivos do crescente desinteresse de alguns educandos pelo aprendizado escolar.

A descrição do material instrucional está contida no Capítulo 3. Nele procuramos apresentar a teoria construtivista que embasou a construção do PROQUIM, as atividades que serviram como norte para a realização desta Dissertação e os conteúdos que se esperam que sejam desenvolvidos com os alunos, para a formação de conceitos que envolvem processos de reações químicas.

A metodologia que orientou os caminhos a serem percorridos pela pesquisadora está apresentada no Capítulo 4. Neste capítulo procuramos salientar algumas características do ambiente de realização da pesquisa e dos sujeitos envolvidos no processo. Delineamos, também, o conceito que está sendo estudado e as etapas que permeiam a formação deste conceito na estrutura cognitiva dos educandos. Para tanto, categorias e subcategorias de análise foram escolhidas conforme os estudos realizados por VIGOTSKI (2005). Das mensagens expressas pelos educandos, durante a realização das atividades sugeridas, no material instrucional, obtivemos dados para unitarização e posterior análise, segundo proposto por BARDIN (2006).

A análise dos dados encontrados para responder às perguntas que originaram a presente investigação está tratada no Capítulo 5. Foram observadas, nesta análise, as expressões dos educandos relacionando os aspectos macroscópicos dos materiais em sistemas sob estudo de transformação. Observamos que parte dos educandos identifica aspectos distinguíveis dos materiais antes e após o processo de modificação dos materiais e outros apenas listam as características de um produto já finalizado. Também a partir de atividades propostas no material instrucional e selecionadas para obtenção de dados, analisamos as etapas de formação do conceito de transformação e notamos a progressiva diferenciação na estrutura cognitiva de alguns educandos.

Concluímos, então, como apresentado no Capítulo 6, que parte dos educandos conseguiu ressignificar o conceito de transformação, porém ainda se faz necessário um maior comprometimento dos educadores, em geral, com o desenvolvimento de atividades que preconizem a construção de conceitos científicos. Deste modo, podemos dizer que a ação colaborativa existente entre a educadora e os educandos e entre os próprios educandos promoveu a construção significativa do conhecimento. 


\title{
Capítulo 2
}

\section{As relações colaborativas e o}

\author{
processo de construção do \\ conhecimento escolar
}

“Os novos desafios a serem enfrentados pelo Ensino Médio precisam ser compreendidos identificando-se suas verdadeiras causas, propondo-se medidas que não sejam ideológicas, populistas, demagógicas ou clientelistas" (SILVA et al., 2005) 


\subsection{Vigotski e a dimensão cognitiva do desenvolvimento humano no espaço da educação escolar}

O desenvolvimento humano inicia-se muito tempo antes do educando começar a freqüentar o espaço educacional, sendo que desde o início de sua vida mantém relações de sociabilidade para se comunicar com seus semelhantes. ELEUTÉRIO (2006, p. 23) afirma que “(...) a criança é um ser social, mas que depende da interação com o meio para se desenvolver. Pois se isolarmos uma criança impedindo que ela interaja ou seja estimulada, conseqüentemente terá seu desenvolvimento emocional e afetivo comprometido."

Dessa forma, como afirma VIGOTSKI (2005), inicialmente a criança utiliza-se da linguagem apenas para se comunicar com aqueles com quem convive e, conforme a criança vai se desenvolvendo, a linguagem verbal passa a ser utilizada para expressar o seu pensamento, que é o resultado das interações que os indivíduos mantêm entre suas habilidades cognitivas e o meio no qual se desenvolvem.

A partir dessas interações com o meio, os indivíduos começam a se desenvolver intelectualmente, principalmente no ambiente escolar, que até há pouco, era tido como espaço onde o aluno era um receptor passivo, que nada sabe, sendo o ensino centrado no professor e nos conteúdos por ele transmitidos, de forma descontextualizada com a realidade e pouco aproveitável ou significativo (LABURÚ \& CARVALHO, 2005; PELIZZARI et al., 2002; SLOMP \& FISCHER, 2006).

Essa realidade começou a se transformar com a participação crescente e ativa da sociedade que, a partir das mudanças pertinentes ao seu desenvolvimento, passou a exigir de seus cidadãos, cada vez mais, atitudes críticas e reflexivas a serem desenvolvidas a partir da relação professor-aluno-escola, pois como expressam BARBOSA-LIMA et al. (2006, p. 237), “(...) escola é o espaço onde se constrói comunitariamente o conhecimento (...)”.

MAGALHÃES (2003) relata em suas pesquisas que o conhecimento não é imutável e, portanto, está em constante processo de modificação. Nesse caso, o diálogo facilita a construção de significados comuns, o que seria impossível numa organização escolar que promove a aprendizagem individualizada. Esse autor também comenta que o importante e mais valorizado nos métodos educacionais que estão sendo propostos hoje em dia é ensinar os educandos a "aprender a aprender", incentivando-os a construírem o próprio conhecimento, pois como o mundo está em constante processo de transformação, muito do que é aprendido na escola acaba se perdendo rapidamente. 
Desse modo, quando o aluno é estimulado a construir seu próprio conhecimento, acaba por encontrar significação no seu aprendizado, o que pode levar à diminuição na desmotivação e desinteresse pela escola, pois ele percebe que seus saberes, desenvolvidos também em ambientes distintos da escola, estão sendo levados em consideração por seus professores. Assim, a relação educativa está vinculada à atuação dos seres humanos ao se relacionarem uns com os outros para a construção coletiva do conhecimento (MOSQUERA \& STOBÄUS, 2006; PEREIRA et al., 2007; RIBEIRO \& JUTRAS, 2006).

Quando se pensa na construção coletiva do conhecimento, em um ambiente institucionalizado, chamado pela sociedade de ESCOLA ${ }^{3}$, é preciso considerar os aspectos relevantes ao relacionamento humano, a fim de diminuir as dificuldades de aprendizagem que muitas vezes podem surgir devido ao não ajustamento entre professores e alunos, que são os sujeitos do processo educacional, visto que, quando os alunos rejeitam o professor e a disciplina por ele ministrada, perdem o interesse em freqüentar a escola, o que contribui para o aumento de suas limitações na trajetória escolar (SILVA et al., 2005).

Essas limitações podem estar relacionadas ao ensino fragmentado (SILVA et al., 2005) e autoritário ainda presentes em escolas brasileiras, que adotam uma educação baseada em práticas pedagógicas mecanizadas em que o aluno age apenas como espectador passivo inserido em "(...) um ensino assentado no escute, leia, decore e repita" (BEHRENS, 1999 , p. 384). Conseqüentemente, o fracasso escolar se torna cada vez maior nas escolas públicas, que são freqüentadas, quase que somente, por alunos pertencentes à classe menos favorecida socialmente (GAMA et al., 1991).

Em vista disso, as atuais propostas de ensino visam estimular as interações sociais e o desenvolvimento cognitivo dos educandos e educadores, que interagem de forma satisfatória quando os conteúdos curriculares estão relacionados às potencialidades dos envolvidos nos processos de ensino e aprendizagem. Isto ocorre porque no uso de sua estrutura cognitiva, os indivíduos articulam uma variada seqüência de eventos para promoverem a ampliação do que já conhecem adicionado ao que pretendem conhecer. Esta apreensão ocorre de forma singular para cada um que participa do processo de aprendizagem, que se dá durante toda a vida através do uso de significados relevantes para si (TAVARES, 2004).

\footnotetext{
${ }^{3}$ A escola (no sentido da skholé grega) é a partir de então a instituição e o lugar por excelência onde se visa a que possam ser transmitidos e apropriados, não quaisquer saberes e práticas, mas prioritariamente determinados saberes e determinadas práticas que, ao mesmo tempo, requerem e permitem um trabalho e uma postura de objetivação, de distanciamento do mundo (pelo menos de certos objetos do mundo), da linguagem e da experiência que temos com ela, trabalho e postura que fazem deles objeto de estranheza ou de inquietude, de questionamento, de reflexão, de análise e de saber e que, no mesmo movimento, constituem o sujeito como foco de suas atividades (ROCHEX, 2006, p. 648).
} 
A partir dessa realidade, observa-se que o diálogo é empregado não somente como meio de comunicação, mas também como meio facilitador do relacionamento com o saber instituído, diminuindo assim as defasagens intelectuais dos educandos (ROCHEX, 2006).

Muitas vezes, o fato dos alunos não apresentarem o hábito da reflexão crítica presente no processo dialógico revela-se claramente em dificuldades na aprendizagem escolar e acaba se tornando mais um fator para sua desmotivação, pois não conseguem compreender com clareza as atividades propostas por seus professores. Corroboram esse pensamento NEHRING et al. (2002), ao citarem em suas pesquisas que muitos alunos se vêem desmotivados quando percebem que os exercícios escolares estão sendo abordados sem vínculo algum com o que lhes é interessante, ou seja, sem relação nenhuma com o contexto que lhes é significativo.

Portanto, a descontextualização entre o conteúdo apresentado e o conhecimento que está à volta dos educandos, bem como a falta do hábito da leitura e da escrita, se tornam os principais motivos para os alunos não demonstrarem interesse e compromisso com a própria aprendizagem (DINIZ, 2007). Esse fato se confirma ao encontrarem-se alunos com baixo rendimento escolar e que apresentam deficiência nas reflexões sobre suas ações, não reconhecendo suas próprias dificuldades e a qual estratégia deveriam recorrer para poder superá-las.

RIBEIRO (2003, p. 110 e 115), diz que “(...) o conhecimento que o aluno possui sobre o que sabe e o que desconhece acerca do seu conhecimento é fundamental para utilização de estratégias de estudo e, conseqüentemente, para melhoria do desempenho escolar (...)". A melhoria no seu desempenho está relacionada com o anseio que o aluno possui para com o seu aprendizado e ao ambiente no qual está inserido, o que requer um "(...) envolvimento ativo do aprendiz na construção do próprio conhecimento, reconhecendo e representando situações através de repertório de estratégias suscetíveis de se poderem aplicar (...)”. Desse modo, se os alunos freqüentarem um ambiente afetuoso e agradável, participarão com maior dedicação das atividades propostas e contribuirão ainda mais para o atendimento dos objetivos educacionais.

Assim, é fundamental valorizar o ensino de Química no cotidiano escolar, pois ele envolve o desenvolvimento do pensar e agir de forma reflexiva, oferecendo aos alunos instrumentos para o desenvolvimento de suas habilidades e "(...) isto significa ajudar o aluno a aprender, observar, elaborar hipóteses, obter dados, aplicar o conhecimento às novas situações, planejar e realizar investigações (...)" (MIGLIATO FILHO, 2005, p. 24), vinculando o sucesso escolar à motivação para estudar Química e outras disciplinas do currículo escolar. 
Por fim, SCHNETZLER (2004, p. 49), ao se referir ao conhecimento Químico construído no ambiente socializador de idéias e conceitos, diz que:

“(...) é nesta instituição social chamada escola que, por meio da mediação docente, os alunos poderão ter acesso a e se apropriar de conhecimentos historicamente construídos pela cultura humana - conhecimentos científicos/químicos - que lhes permitem outras leituras críticas do mundo no qual estão inseridos."

Pode-se dizer, então, que é na escola que se encontra o comprometimento com a produção coletiva do conhecimento e é nela que o aluno se desenvolve intelectualmente, construindo um aprendizado que lhe permitirá interferir criticamente na sociedade, dispondo de estratégias e habilidades que foi adquirindo ao longo de seu desenvolvimento.

O desenvolvimento do homem como ser social requer o controle de seu comportamento através de processos estabelecidos a partir das impressões que advêm do mundo exterior à escola, o que o coloca em contato com uma cultura historicamente estabelecida, como resultado das relações que se mantêm através do processo dialógico. Nesse caso, cabe ao professor o despertar do interesse do aluno, vinculando sempre a aprendizagem, advinda da construção de significados, a um trabalho ativo e dinâmico.

Assim, a escola se torna responsável pelo desenvolvimento intelectual do educando ao despertar seu interesse pela elaboração do próprio conhecimento e quando promove mediações deste com o meio social para a ressignificação do conhecimento, integrando no mesmo ambiente educador e educandos com objetivos em comum. Nessa perspectiva é que se desperta a consciência cidadã do educando, utilizando-se da palavra como elemento essencial de garantia de possibilidades de troca de experiências (BARBOSA-LIMA et al., 2006), ou ainda "(...) é nesse sentido que o educador precisa considerar que a fala é um instrumento para comunicar as novas formas de relacionamento, experiências e conhecimentos dos indivíduos entre si (...)" (SLOMP \& FISCHER, 2006, p. 102). Portanto, “(...) é necessário fazer acontecer nas escolas (...) a cultura viva, diversificada e criativa que representa o conjunto de formas de pensar, agir e sentir dos alunos (...)" (SLOMP \& FISCHER, 2006, p. 100).

CASTILHO et al. (1999, p. 16), em seus apontamentos, ao considerarem a palavra escrita ou falada como forma principal de comunicação entre os sujeitos, dizem que "(...) a linguagem usada é um fator essencial, uma vez que pode representar e desenvolver concepções diversas, e, quem sabe, reforçar concepções distorcidas (...)". Isso deve levar professores, escolas, familiares e todos que fazem parte da formação do educando a reverem suas posturas frente aos acontecimentos, pois seus discursos podem influenciar a 
formação dos educandos que, futuramente, se utilizarão de seus exemplos para conceber suas próprias convicções frente a uma sociedade em constante processo de transformação.

A influência de indivíduos mais experientes leva os educandos a se relacionarem com seus semelhantes através de uma linguagem culturalmente construída "(...) como sistema simbólico básico de todos os grupos humanos (...)" que, para Vigotski “(...) fornece a mediação entre o sujeito e o objeto do conhecimento" (OLIVEIRA, 1992, p. 80).

As palavras nesse sistema simbólico de comunicação têm, para Vigotski, um significado que se formou no processo de desenvolvimento compartilhado por todas as pessoas que as utilizam, porém fazendo um sentido individual para cada um. Assim, ao se considerarem as relações que os indivíduos mantêm entre si e o alcance que suas experiências pessoais proporcionam no desenvolvimento da cultura, é necessário, também, observar que a “(...) construção de sujeitos absolutamente únicos, com trajetórias pessoais singulares e experiências particulares em sua relação com o mundo e, fundamentalmente, com as outras pessoas (...)" se dá não somente através da interação com os indivíduos, mas também através das "(...) possibilidades intelectuais de cada um (...)" (DANTAS, 1992, p. 96; OLIVEIRA, 1992, p. 80).

É importante ter em mente que o indivíduo já vem para a escola com uma gama de conhecimentos a serem considerados em sua autoconstrução e na reunião dos diferenciados pontos de vista necessários à ação coletiva do ser humano ao articular-se com o outro, em um ambiente onde se criam novos conhecimentos e onde se cria uma cultura diversificada (SLOMP \& FISCHER, 2006; VEIGA \& WEIDUSCHAT, 2004). Portanto, a linguagem utilizada deve envolver os alunos em um sistema que permita ao professor se comunicar através do compartilhamento de informações, tendo por meta a apresentação dos conteúdos escolares de acordo com a realidade do educando, considerando seus saberes e relacionando-os com os objetivos dos conteúdos estabelecidos como necessários de serem aprendidos.

Para VEIGA \& WEIDUSCHAT (2004, p. 22), “(...) com esse tipo de proposta educacional, a escola entende que da mesma forma que os estudantes aprendem a somar, a conhecer a natureza e a se apropriar da escrita, é fundamental para suas vidas que se conheçam e conheçam seus colegas (...)". Corroboram essa discussão LA TAILLE et al. (1992), ao escreverem sobre a teoria do desenvolvimento humano. Estes autores mencionam, em seus estudos, que os alunos, através do contato com pessoas mais experientes, ressignificam o conhecimento através das reinterpretações de informações apresentadas pela sociedade e o interiorizam quando se torna verdadeiro para si, passando a utilizá-lo como instrumentos de ação para modificar o mundo em que vivem. 
VIGOTSKI (2005), em sua teoria, discute essa mesma relação homem/mundo e a influência que suas ações podem causar ao desenvolvimento cultural. Para ele, cada grupo social possui suas especificidades, que foram sendo construídas historicamente, partindo do percurso individual de cada um e das ações dos outros sobre o indivíduo. Assim, ele afirma que o conhecimento do homem modifica a sociedade e a sociedade modifica as ações do homem sobre ela mesma, ou seja, o conhecimento construído cotidianamente modifica o conhecimento científico e vice-versa, o que pode ser percebido pela linguagem utilizada pelos alunos quando da interação com seus pares ou com pessoas mais experientes.

Os processos de ensino e aprendizagem se influenciam reciprocamente pela relação interpessoal do professor-aluno-escola, considerando que esta última deve possuir um ambiente agradável para o desenvolvimento intelectual, tanto do educando como do educador, pois numa relação dialógica, tanto o processo de ensino como o de aprendizagem ocorrem concomitantemente.

Os alunos ao encontrarem um ambiente harmonioso e um professor interessado no que faz, motiva seus alunos a procurarem um significado na aprendizagem. Esse fato fica claro quando alunos repetem e interiorizam as ações de seus professores e se apropriam da linguagem utilizada pelos mesmos (OLIVEIRA, 1992). Contudo, o professor precisa considerar que o aluno vem para a escola com saberes previamente estabelecidos em sua estrutura cognitiva e que muitas de suas ações - do professor - irão influenciar o seu desenvolvimento intelectual - do educando - pois este vê no professor um exemplo a ser seguido. Ao mesmo tempo, os alunos interiorizam as falas e ações de pessoas mais experientes, por acreditarem que elas têm um saber culturalmente aprimorado.

Os educandos procuram na escola e nos professores fatores motivacionais para despertar-Ihe o interesse pelo saber, sendo que a escola possui características próprias e é o único ambiente que coloca em contato cotidiano pessoas com conhecimentos e saberes próximos, diferentemente de qualquer outro lugar que se considere culturalmente desenvolvido. É nesse mesmo ambiente que professor e aluno se encontram para compartilhar a construção do conhecimento.

Assim, PELIZZARI et al. (2002, p. 40) sugerem que os alunos realizem aprendizagens por si sós, em que o aprender a aprender implica em sua participação ativa na aquisição de conhecimentos para sua própria reelaboração pessoal, vinculando e ampliando o que já sabem com os novos conhecimentos adquiridos.

MOLL (1996), esclarece que o papel da escola e, por conseguinte, do adulto, não é o de fornecer o caminho pronto que os alunos devem seguir para seu pleno desenvolvimento, 
mas sim, ter por objetivo torná-los suficientemente atentos para reorganizarem seus conhecimentos e experiências para utilização em situações novas e concretas de comunicação com o mundo.

É nesse contexto que a relação predominante no ambiente escolar é a existente entre professores e alunos e esta deve estabelecer-se através de uma linguagem que facilite a relação de proximidade de ambos os sujeitos dos processos de ensino e aprendizagem, em um ambiente em que o professor tenha reais condições de assistir seus alunos na zona de desenvolvimento proximal. MOLL (1996, p. 14) afirma que "(...) a zona de desenvolvimento proximal (...) integra dinamicamente o indivíduo e o ambiente social (...)" de maneira que este se torne capaz de resolver um conflito que anteriormente não era capaz de resolver sozinho.

O contexto social no qual os educandos estão interagindo, no caso a escola, promove, através das ações dos professores, a criação de zonas de desenvolvimento proximal, na qual os alunos possuem informações diversificadas para executarem as atividades propostas. Porém, nela ainda estão presentes informações desordenadas que precisam do auxílio de pessoas mais experientes que ajudem na organização e desenvolvimento do pensamento (SHAFFER, 2005). Assim, o papel da escola se torna de grande importância ao gerar situações que coloquem os alunos em colaboração com seus semelhantes, através do diálogo e ensino interativos. Nesse conjunto, os indivíduos empregam a comunicação e o uso das palavras como formas de aprimoramento da linguagem simbólica para a formação de conceitos.

A escola também é responsável por criar situações para o domínio e o manejo consciente dos usos desses instrumentos culturais de comunicação, auxiliando o desenvolvimento intelectual dos educandos e integrando-os ao ambiente, pois, como afirma DANTAS (1992), a linguagem é capaz de conduzir e alimentar o pensamento.

Em vista disso, conclui-se que, ao longo do desenvolvimento do intelecto, o ser humano se torna capaz de utilizar a linguagem e adaptá-la às suas condições pessoais, adquirindo um sentido próprio e intransferível, cuja compreensão apenas é idiossincrática. Assim, a linguagem como instrumento de construção do pensamento, adquire aspectos e significados a serem compartilhados nos mais variados contextos de aprendizagem. 


\subsection{A zona de desenvolvimento proximal como instrumento de construção do pensamento: o uso de símbolos e a prática da ação colaborativa durante as etapas da formação de conceitos}

VIGOTSKI (2005) e seus colaboradores, em seus estudos, concluíram que a formação de conceitos se inicia na mais tenra infância, porém o amadurecimento do intelecto somente se configura na adolescência. Entre a infância e a adolescência o sujeito se desenvolve intelectualmente a partir das experiências vividas e do contato com seus semelhantes. Esse contato com as experiências alheias permite que o intelecto passe por um desenvolvimento gradual.

As operações mentais do educando atingirão seu pleno amadurecimento no momento em que o repertório de informações, presentes em sua estrutura cognitiva for suficiente para enfrentar o conflito surgido em sua zona de desenvolvimento proximal. Esse repertório de informações é representado no uso de signos, ou palavras, “(...) como meio pelo qual conduzimos as nossas operações mentais, controlamos o seu curso e as canalizamos em direção à solução do problema que enfrentamos (VIGOTSKI, 2005, p. 73)".

Segundo VIGOTSKI (2005, p. 74-101), a formação de um conceito se inicia na infância, sincretismo, a partir de um aglomerado de informações e imagens impostas a um mesmo signo, relacionáveis entre si apenas na percepção das crianças (organização do campo visual), porém em constante processo de transformação, por não apresentarem um elo concreto e serem criados ao acaso (tentativa e erro), ou mesmo por elementos que são tirados dos grupos já organizados sincreticamente, sem nenhum critério de escolha, por meio de uma operação que se processa em duas etapas, uma de construção desses grupos e a seguinte de desconstrução desse mesmo grupo.

$\mathrm{Na}$ fase seguinte, as crianças já tentam dar significados às palavras por meio de uma complexa e ordenada seqüência de elementos (pensamento por complexos), estabelecendo relações que realmente existem entre os objetos, distanciando-se, então, do sincretismo e aproximando-se do pensamento objetivo, contudo ainda sem refletir sobre essas relações como no pensamento conceitual, mas afastando-se das relações que mantinham entre suas percepções e aproximando-se das reais propriedades concernentes a esses objetos.

No pensamento por complexos, os elos estabelecidos entre os signos possuem uma unidade lógica fundamentada por fatos concretos que podem variar entre si, através de semelhança, contraste ou pela proximidade no espaço, ao nível da percepção (associativo). 
Em outra etapa, semelhante ao estágio associativo (coleções), pode haver a combinação de objetos em grupos que se assemelham por características que os tornam diferentes de outros objetos e são complementares entre si, como cor, forma, tamanho, formando coleções associativas, observadas na experiência prática.

O complexo em cadeia (p. 79) - “(...) junção dinâmica e consecutiva de elos isolados numa única corrente, com a transmissão de significado de um elo para o outro (...)" - se dá quando a criança tem um critério para selecionar os atributos dos objetos que se assemelham para formar o grupo que está organizando e, em seguida, através da inserção de um novo elemento, os critérios de seleção dos objetos se modificam, variando, então, o vínculo entre os objetos desse grupo.

O quarto estágio da segunda fase é denominado por Vigotski de complexo difuso, sendo assim denominado por reunir os objetos concretos através de conexões dispersas, agrupando-os de maneira ilimitada, gerando elos conectivos difusos ao longo das associações que o sujeito coordena em suas operações mentais, para reunir os objetos em determinado conjunto.

No quinto e último estágio do pensamento por complexos, a criança já é capaz de fazer generalizações do significado das palavras a partir do repertório de informações aprioristicamente apresentadas, “(...) se orientando por uma semelhança concreta visível, formando um complexo associativo (...)" (p. 83), semelhante à formação de conceitos realizada pelos adultos (pseudoconceito), porém diferente do conceito propriamente dito.

O pseudoconceito possui, em suas definições, concepções espontâneas criadas pelas crianças que, se por um lado carregam um sentido próprio, por outro se relacionam e se completam com os conceitos partilhados pelo contexto social. Assim, o conceito real possui significados construídos pelos adultos e intermediados pela linguagem do meio ambiente, pré-determinando o caminho que as crianças deverão seguir para fazer suas próprias generalizações e atribuir sentido ao conceito que se assemelhe ao estabelecido pelos adultos.

Entretanto, quando as crianças significam signos ao criarem suas primeiras palavras para poderem se comunicar, ocorre uma mistura das formas de pensamentos que refletem as características diversas dos objetos, associando-se em um mesmo grupo por relações perceptíveis macroscopicamente. Nessa fase intermediária as crianças relacionam fatos, características e imagens atribuindo os mais variados significados às palavras. Assim, uma palavra pode admitir várias definições diferentes, porém relacionadas entre si através de 
algum atributo em comum, ou seja, algum elo associativo, mas podendo passar por infinitas alterações. VIGOTSKI (2005, p. 87), as chama de complexo associativo e imagem sincrética.

No estudo do pensamento por complexos, ainda na fase associativa, há um aglomerado de signos e imagens designados para a mesma palavra, com vários atributos semelhantes unidos através de algum elo associativo. Contudo, ao mesmo tempo em que a imagem que diferencia a palavra vai desaparecendo da memória da criança o pseudoconceito vai se formando pelo estabelecimento de relações que vão se ordenando, porém, promovendo generalizações deficientes em abstrações. A abstração é uma característica encontrada na terceira fase da formação de conceitos.

A terceira fase de ordenação do pensamento para a formação de conceitos é dividida em dois estágios denominados conceitos abstratos e potenciais.

No estágio designado conceitos abstratos propõem-se o agrupamento dos objetos não pela observação do concreto, mas através da unificação dos elementos pela abstração e isolamento de dados estáveis, pela sua síntese e análise (VIGOTSKI, 2005), a partir de um grau máximo de semelhança. Ao mesmo tempo em que os grupos são criados a partir da semelhança, estes são excluídos do mesmo grupo pelas diferenças próprias a cada objeto.

No estágio conceitos potenciais os grupos são gerados a partir de um único atributo perceptível (impressões) ou quando estão voltados para a mesma ação (função semelhante).

"Somente o domínio da abstração, combinado com pensamento por
complexos em sua fase mais avançada, permite à criança progredir até a
formação dos conceitos verdadeiros. Um conceito só aparece quando os
traços abstraídos são sintetizados novamente, e a síntese abstrata daí
resultante torna-se o principal instrumento do pensamento." (VIGOTSKI, 2005,
p. 98)

No desenvolvimento dos processos intelectuais dos adolescentes, cada vez mais as formas de pensamento encontradas na infância, no início da apropriação da linguagem, vão se desvanecendo e dando lugar ao pensamento conceitual. Nos adolescentes, essa forma de pensamento se encontra em constante manifestação, principalmente quando se utilizam de conceitos recentemente adquiridos em uma situação concreta. Contudo, ao se depararem com uma situação que esteja contextualizada em âmbito diferente ao qual se deu a construção de determinado conceito, há demonstração de dificuldades na transposição de noções recém-construídas para essa situação específica. Em vista disso, de forma dialética, ele recorre a sua forma primitiva de pensamento. 
Os adolescentes, ao construírem seu pensamento em situações pragmáticas e na medida em que necessitam aplicar suas idéias, caracterizadas de forma abstrata, encontram-se em situação conflitante que se resolve ao buscarem noções adquiridas em uma dada situação original de construção de pensamento. Em outras palavras, os pensamentos, primitivo e por complexos, coexistem na mesma realidade na fase adolescente. A Tabela 2.1 apresenta a ordenação básica do desenvolvimento das operações intelectuais, para a formação de conceitos desde a infância até a adolescência.

Tabela 2.1 - Fases de ordenação do pensamento para formação de conceitos, conforme proposto por VIGOTSKI (2005)

\begin{tabular}{|c|c|c|c|}
\hline \multirow{12}{*}{ 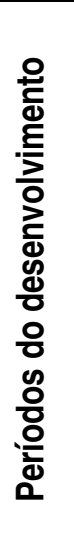 } & & Fases & Estágios \\
\hline & \multirow{11}{*}{ 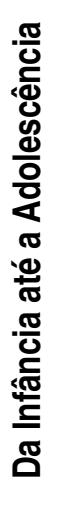 } & \multirow{3}{*}{$1^{a}-$ Sincretismo } & Tentativa e erro \\
\hline & & & Organização do campo visual \\
\hline & & & Aglomeração e desaglomeração $0^{4}$ \\
\hline & & \multirow{5}{*}{$\begin{array}{c}2^{a}-\text { Pensamento por } \\
\text { complexos }\end{array}$} & Associativo \\
\hline & & & Coleções \\
\hline & & & Cadeia \\
\hline & & & Complexo difuso \\
\hline & & & Pseudoconceito \\
\hline & & Intermediária ${ }^{5}$ & Complexo associativo e imagem sincrética: participação \\
\hline & & \multirow{2}{*}{$3^{a}-$ Pensamento conceitual } & Conceitos abstratos \\
\hline & & & Conceitos potenciais \\
\hline
\end{tabular}

A formação propriamente dita do conceito ocorre quando os educandos entram na adolescência. Nesse período, os sujeitos são capazes de compreender os objetivos de uma atividade e de executá-la da mesma forma que um adulto para alcançar a finalidade proposta. Porém, a diferença entre o pensamento do adolescente e do adulto é o procedimento que utilizam para atingir o objetivo (VIGOTSKI, 2005).

“(...) a formação de conceitos é um processo criativo, e não um processo mecânico e passivo; que um conceito surge e se configura no curso de uma operação complexa, voltada para a solução de algum problema; e que só a presença de condições externas favoráveis a uma ligação mecânica entre a palavra e o objeto não é suficiente para a criação de um conceito (VIGOTSKI, 2005, p. 67)."

Para formar um conceito o indivíduo mobiliza suas funções psíquicas superiores, através das quais utiliza signos que servirão como meio para construir o conhecimento. Segundo VIGOTSKI (2005), o signo mediador dessas funções mentais são as palavras que, após a interiorização de seu significado, tornam-se símbolos.

\footnotetext{
${ }^{4}$ A classificação do terceiro estágio da fase do sincretismo foi assim chamada a fim de facilitar a análise dos dados coletados durante a pesquisa.

${ }^{5}$ A fase intermediária foi assim chamada por apresentar características mistas do primeiro e do segundo estágios do desenvolvimento do pensamento das crianças.
} 
Quando se induz uma perturbação na estrutura mental de um sujeito, seus conhecimentos prévios são disponibilizados, porém nem sempre esses conceitos já estão formalizados, ou seja, pode não haver ainda um símbolo que sirva como elo para compor o conceito necessário à aprendizagem, tornando-se essencial o contato com o grupo no qual ele está incluído para que adquira o conhecimento necessário à resolução do problema apresentado.

Ao manter contato com uma pessoa que possui maior conhecimento e experiência, em determinada atividade, ocorre uma interação em que há a assistência e a transferência de informações (MOLL, 1996, p. 181). O individuo mais experiente media as ações do outro e compartilha com ele seus conhecimentos, difundindo assim o percurso realizado, para que ele possa desenvolver suas próprias capacidades.

No caso dos alunos interagirem com o grupo do qual fazem parte, ou seja, com companheiros mais experientes ou capazes de solucionar com maior precisão determinadas situações, pode ocorrer uma apropriação da linguagem utilizada como meio facilitador da aprendizagem, mesmo que de forma inconsciente, para a construção do próprio conhecimento. Portanto, através dessa interação criam-se zonas de desenvolvimento proximal que, para VIGOTSKI (1991, p. 97), existem a partir da distância entre o nível de desenvolvimento real, "(...) que se costuma determinar através da solução independente de problemas (...)" e o nível de desenvolvimento potencial “(...) determinado através da solução de problemas sob a orientação de um adulto ou em colaboração com companheiros mais capazes."

Essa distância entre o desenvolvimento real e o desenvolvimento potencial manifestase pelos conceitos que já estão devidamente amadurecidos e aqueles que estão por amadurecer e que dependerão do desenvolvimento mental do educando para constituição de um sentido próprio, mesmo que utilizado por imitação em uma atividade sob orientação de uma pessoa mais experiente. Como diz VIGOTSKI (1991, p. 99), “(...) o aprendizado humano pressupõe uma natureza social específica e um processo através do qual crianças penetram na vida intelectual daquelas que as cercam." Nesse sentido, compete ao professor promover atividades de aprendizagem de acordo com o desenvolvimento intelectual dos educandos e com o contexto social no qual eles estão inseridos, fomentando processos investigativos que os levem a se interessarem pela aprendizagem de novos conceitos.

A gênese de novos conceitos na estrutura cognitiva dos educandos, não é de fácil constituição, mesmo quando os sujeitos do processo de construção do conhecimento estão inseridos no ambiente formal de ensino. Todavia, a comunidade escolar atua ampliando a intercomunicação de informações com o objetivo de facilitar a ressignificação do 
conhecimento, considerando as experiências individuais dos educandos e seu desenvolvimento a partir da interação com meio do qual fazem parte.

As funções psicológicas superiores se desenvolvem “(...) por meio da imersão cultural nas práticas das sociedades, pela aquisição dos símbolos e instrumentos tecnológicos da sociedade e pela educação em todas as suas formas (MOLL, 1996, p. 3)".

Os símbolos a que MOLL (1996) se refere são os que se desenvolvem em situações concretas de aprendizagem. Para tanto, é fundamental a cooperação entre professores e alunos, pois eles constituem o centro do processo educacional. Conseqüentemente, a ação colaborativa que norteia a construção do conhecimento escolarizado deve pautar-se em uma linguagem que permita ao professor auxiliar na formação de um aluno mais crítico e conhecedor da importância da leitura e da escrita como meios indissociáveis de desenvolvimento da ciência e melhoria da aprendizagem química (FLOR, 2008).

Para que o símbolo consiga representar a formação do conceito desejado, as palavras utilizadas na fala cotidiana desenvolvem-se tanto no diálogo fora da escola como no discurso escolarizado, envolvendo tanto conceitos constituídos no dia-a-dia quanto os científicos, tornando as palavras proferidas objetos de estudo. Essas palavras vão adquirindo novos significados a partir do momento que os envolvidos na construção do pensamento influenciam as representações de cada um, ou seja, o diálogo existente entre os participantes dos processos de ensino e aprendizagem permite um acesso às experiências do outro e ao seu compartilhamento com seus semelhantes.

Esse compartilhamento de conhecimentos e valores favorece a constituição comunitária do conhecimento, a partir de relatos de experiências individuais para posterior utilização dessas informações em situações propostas para o desenvolvimento intelectual do educando. Desse modo, considera-se que o desenvolvimento da estrutura cognitiva dos participantes do processo educacional não é estático e sim uma construção dinâmica em constante adaptação às necessidades que a sociedade solicita de seus membros culturalmente envolvidos em sua transformação. Portanto, para que ocorra o desenvolvimento cognitivo dos alunos, é importante priorizar as informações que eles trazem do universo exterior às paredes da escola, pois, é no contato com o meio, que suas experiências serão valorizadas (CIRINO, 2006).

Para que os alunos possam se desenvolver intelectualmente a fim de transformar a realidade da sociedade da qual são participantes ativos, é conveniente que saibam empregar as informações que adquiriram dentro da escola em situações que demandem a adaptação do conhecimento construído em sua estrutura mental para a resolução do 
problema apresentado. Assim, como a sociedade é flexível às adaptações do mundo globalizado, também o é a rede de significações estabelecida coletivamente no ambiente escolar. Portanto, o aluno estabelece conexões entre o conhecimento constituído a partir de suas experiências no dia-a-dia, adaptando-o às informações que lhe são apresentadas no ambiente formal da sala de aula, através de um currículo determinado pelo contexto da sociedade em transformação.

JUNIOR et al. (2008), ao escreverem um artigo em que relatam uma pesquisa com abordagem investigativa qualitativa, realizada com 21 alunos (primeira etapa) e 20 alunos (segunda etapa), de um curso pré-vestibular da cidade de Araraquara (SP), todos provenientes de escolas públicas e pertencentes a famílias com baixa renda, teve por objetivo discutir estratégias de resolução de problemas.

Tanto na primeira, como na segunda etapa, o professor-pesquisador observou que aproximadamente $80 \%$ dos alunos conseguiram realizar a atividade proposta sem o auxílio do professor, contando apenas com informações presentes na situação-problema e outras apresentadas em aulas anteriores, porém sem serem discutidas naquele momento. Já $20 \%$ dos alunos (04 alunos) necessitaram de maiores informações, fornecidas pelo professor, para encerrar a atividade. Destaca-se que, nas duas situações, todos os alunos articularam estratégias a partir de seus conhecimentos para a resolução do problema.

Em ambos os casos, o pesquisador notou que a prática da ação colaborativa entre os pares é imprescindível, ou seja, o diálogo favorece a reelaboração de estratégias e conceitos pré-existentes na estrutura cognitiva de cada um, por meio do pensamento crítico e reflexivo necessário nos processos investigativos e utilizado para a construção significativa de conceitos científicos.

\footnotetext{
"Atividades de exposição e debate dos resultados experimentais constituem-se numa forma promissora de validação pessoal e social do conhecimento engendrado em sala de aula, sendo uma maneira de tornar tais conhecimentos mais significativos pessoalmente". (JUNIOR et al., 2008, p. 90)
}

Ao integrar os conhecimentos existentes dentro e fora da escola, geralmente se promove um diálogo entre os envolvidos em situações de socialização, podendo-se adotar princípios de ensino existentes no ambiente não-escolarizado para melhorar a qualidade do ensino no ambiente escolar. GALVÃO (2008, p. 86) corrobora esse pensamento argumentando que quando ocorre a “(...) interação do conhecimento formal, o pensamento se apropria das diferenciações já feitas pela cultura, as quais contribuem para a realização das diferenciações que devem ser realizadas pelo próprio indivíduo." 
Adotando-se esse tipo de estratégia, as experiências cotidianas dos alunos se tornam presentes no ambiente da sala de aula facilitando o ajustamento dos conceitos científicos até tornarem-se de uso cotidiano. Do mesmo modo, ao se relacionarem os conceitos do diaa-dia à aprendizagem escolar, se estão criando zonas de desenvolvimento proximal, em que os educandos são estimulados a mobilizar determinadas competências já pré-existentes em sua estrutura cognitiva para a resolução de alguma atividade proposta. Assim, o envolvimento em uma atividade só terá sentido quando atingir a zona de desenvolvimento real do educando.

Em conclusão, a formação dos conceitos na estrutura cognitiva dos educandos está em constante processo de adaptação, ora utilizando-se de pensamento associativo por semelhanças, ora abstraindo essas semelhanças para simbolizar um signo que será empregado no desenvolvimento da linguagem. Tais características se evidenciam no ambiente escolar quando os professores se utilizam de conhecimentos químicos na contextualização do conhecimento cotidiano, para o desenvolvimento da linguagem científica.

\subsection{A prática da ação colaborativa na construção do conhecimento escolar durante o processo de formação dos conceitos.}

A construção do conhecimento passa por reestruturações constantemente mediadas pelo conhecimento científico tornando-se de uso rotineiro na vida dos educandos. Isso ocorre quando os alunos internalizam conceitos e atribui-Ihes sentido próprio. Sendo assim, a mediação feita pelo professor durante os processos de ensino e aprendizagem precisa contemplar o pressuposto de que os educandos, quando começam a freqüentar a escola já trazem consigo um conhecimento adquirido pelo convívio com seus semelhantes.

MOLL (1996) cita que os conceitos cotidianos permeiam o desenvolvimento dos conceitos científicos, dando sentido à concepções já existentes na estrutura cognitiva dos indivíduos. VIGOTSKI (2005) observa em seus estudos que, para os educandos, os conceitos científicos são concepções não-espontâneas, ou seja, são conceitos utilizados formalmente para a construção do conhecimento escolar, embora ainda não sejam aplicados pelos alunos à resolução de atividades em que haja necessidade desse repertório de informações. Isso porque esses conceitos não tem sentido para eles.

CARVALHO (2004) admite que em um contexto dialógico de ensino e aprendizagem, compete ao professor organizar o ambiente e as atividades escolares de forma adequada à 
realidade do alunado, com a finalidade de que eles atinjam os objetivos propostos. Entretanto, a ação do professor pode não ser significativa para o aluno se este não estiver em um ambiente apropriado ou se sua estrutura cognitiva não estiver amadurecida o suficiente para mobilizar as competências necessárias para formar determinados conceitos.

"(...) o aprendizado desperta vários processos internos de desenvolvimento,
que são capazes de operar somente quando a criança interage com
pessoas em seu ambiente e quando em cooperação com seus
companheiros." (VIGOTSKI, 1991, p. 101)

Quando os alunos estão envolvidos na construção de seu conhecimento podem surgir concepções alternativas às já existentes, oportunizando o desenvolvimento de explicações a partir de suas perspectivas. Para tanto, as observações dos educandos devem ser confrontadas ao conhecimento já existente e estabelecido socialmente, a fim de se tornar significativo e, assim, facilitar a percepção de novos atributos a serem inseridos à situações de aprendizagem existentes em diferentes contextos (CYRINO \& TORALLES-PEREIRA, 2004; PACHECO, 1997).

Nessa perspectiva, o ensino de novos conteúdos deve permitir que o aluno se desafie a avançar nos seus conhecimentos apoiando-se em uma estrutura cognitiva já existente, o que exige do professor, como tarefa inicial, verificar o que o aluno sabe para relacionar os novos conteúdos à experiência do estudante, provocando seu raciocínio e gerando conflitos cognitivos. Desse modo, o professor revê sua postura para o exercício de um trabalho reflexivo que, freqüentemente, o coloca diante de situações imprevistas, novas e desconhecidas, exigindo que o processo dialógico de construção do conhecimento seja realizado tanto pelo educador quanto pelo educando.

Em vista disso, as atividades investigativas desenvolvidas em laboratório devem suscitar o trabalho em grupo com o propósito de acrescentar habilidades relacionais entre os adolescentes, também por meio da escola. Contudo, MOREIRA (1990) afirma que a percepção do professor para o evento que ocorre no laboratório pode não ser a mesma do aluno, pois a estrutura cognitiva do educando pode não estar preparada para tanto. Logo, o professor, mediador dos processos de ensino e aprendizagem, deve estruturar e selecionar gradativamente os atributos dos problemas apresentados, sendo que "(...) a promoção constante de conflitos cognitivos pode inibir a participação e, em alguns casos, aumentar a atitude negativa para o estudo das ciências (...)" (SILVA \& NÚÑ̃EZ, 2002, p. 1201).

Desse modo, atividades que integram professores e alunos na reelaboração de um conhecimento, possibilitam que os processos de ensino e aprendizagem, mediados através de diferentes recursos estratégicos, sejam reestruturados constantemente pelos integrantes 
da ação educacional, modificando o conhecimento sistematizado (ALMEIDA, 2003; JONASSEN, 1996; SILVA \& NÚÑEZ, 2002).

Assim sendo, quando o professor está interessado na aprendizagem dos educandos, suas ações se tornam mais importantes do que a mera transmissão de conhecimentos e comprovação de uma teoria, possibilitando que os alunos interpretem e aprendam para a percepção dos fenômenos que os rodeiam.

Essas ações podem ser promovidas a fim de estimular a participação do aluno, despertando sua curiosidade e possibilitando ao professor a apresentação de uma aula experimental em meio a uma aula diversificada através da utilização de diferentes recursos estratégicos, como, por exemplo, a apresentação de uma aula experimental durante uma aula que seria meramente expositiva (CARVALHO \& MION, 2004; GALIAZZI \& GONÇALVES, 2004).

"(...) a atividade experimental de demonstração, partilhada por toda classe, sob a orientação do professor em um processo interativo que possa simular a experiência vivencial enriquecedora e fortalecedora dos conceitos espontâneos, pode oferecer também os mesmos elementos cognitivos que dão força e riqueza aos conceitos científicos." (GASPAR et al., 2005, p. 2)

Não obstante, tanto professores como alunos expressam que a diversificação e a criatividade, nas atividades a serem desenvolvidas no âmbito da sala de aula, são a melhor forma de conservar a motivação e o encantamento pela educação (CARDOSO \& COLINVAUX, 1999).

O relacionamento existente entre professores e alunos deve pautar-se no respeito ao próximo e na consideração aos seus saber prévios. Logo, para intervir no cotidiano é fundamental que os alunos possuam um repertório de informações significativas, advindas da construção do conhecimento escolar, para que possam atuar no dia-a-dia da sociedade, por meio de uma linguagem adequada ao conhecimento construído. Portanto, o professor é o responsável pela mediação entre o aprender e o ensinar e o aluno é o sujeito do processo educacional, ambos envolvidos em ações para o desenvolvimento da linguagem científica.

Nesse contexto, as ações empreendidas por alunos e professores durante o progresso de uma atividade envolvem o aprimoramento da linguagem utilizada, pois é através dela que se expressam as hipóteses acerca dos conceitos científicos. Nesse caso, os signos empregados para expressão do conhecimento construído abrangem o uso da escrita para posterior verbalização das idéias acerca do conceito objeto de estudo. Logo, aplicar processos investigativos como alternativos aos procedimentos metodológicos tradicionais, pode ser uma opção para alcançar melhorias no ensino de Química nas escolas brasileiras. 
A motivação para a aprendizagem Química seria facilmente estabelecida no ambiente educacional se o conhecimento escolar estiver interligado ao conhecimento cotidiano (SCHNETZLER, 2004). Porém, sabe-se que na realidade isto não ocorre em todos os momentos, levando professores e alunos a estabelecerem uma relação com o processo educacional apenas pela realização de provas e atividades avaliativas vinculadas aos conteúdos escolares, porque não conseguem encontrar nenhum tipo de relação entre o conhecimento cotidiano e o conhecimento escolar.

A ligação do professor é mais próxima ao objeto que ele pretende que os alunos conheçam, portanto, ele deve planejar atividades que envolvam estratégias que estimulem o aprendizado e o convívio social, favorecendo que todos atuem como alunos e professores. Nessa educação mais inclusiva, o professor torna-se o mediador das interações entre os alunos e o objeto sob estudo. Desse modo, os alunos podem tornar-se co-educadores em salas de aula, gerando comportamentos que se desenvolvem no contato com seus pares, em busca dos mesmos fins (DEL PRETTE et al., 1998; MOSQUEIRA \& STÖBAUS, 2006; RIBEIRO \& JUTRAS, 2006).

Para o professor, ensinar é uma ação intencional para produzir aprendizagens, dinâmica e continuamente, com o objetivo de melhoria da qualidade da educação. Em vista disso, com a finalidade de originar ações auto-avaliativas em seus alunos, cabe ao professor informar-lhes sobre seus êxitos e fracassos, fomentando o pensamento reflexivo, 0 desenvolvimento de capacidades e a motivação para o compartilhamento, com o professor, da responsabilidade pela aprendizagem escolar.

GALÃo et al. (2003) sustentam a opinião de que a melhoria da educação e da relação colaborativa no ambiente escolar se dá a partir de um ensino contextualizado e apropriado à realidade dos educandos e validam essa afirmativa em trabalho experimental realizado com alunos de Ensino Médio da cidade de Rolândia, no Paraná. Para tanto, empregaram como norte de seus estudos um tema motivador que refletisse a realidade vivida pelos educandos e que fosse de fácil compreensão por ser um assunto comum a todos, abordando o tema em aulas expositivas e dialogadas pelo grupo. Assim, ao utilizarem um conceito de uso cotidiano durante a investigação perceberam que, entre outras impressões, a atividade experimental despertou o interesse dos alunos; a interdisciplinaridade estava relacionada nas atividades dos alunos e foi percebida quando avaliada pelos professores e as atividades experimentais são eficazes no desenvolvimento de trabalhos escolares que se utilizam de um tema motivador para ensinar conceitos químicos relacionados a conceitos cotidianos.

Por fim, como enfatizam OLIVEIRA \& CARVALHO (2005, p. 347) “(...) os conhecimentos não aparecem estanques e isolados (...)" eles devem ser construídos a partir da relação 
professor-aluno e aluno-aluno, vinculando o respeito entre ambos ao diálogo existente entre as partes, para que o processo de ensino e aprendizagem resulte em uma passagem realmente significativa na vida escolar do educando. Portanto, como afirmam VASCONCELOS et al. (2005), “(...) é preciso respeitar o outro no seu modo de ser e assim garantir um bom relacionamento, possibilitando um clima de confiança (...)", cabendo ao professor utilizar-se competentemente desse bom relacionamento para orientar a construção do conhecimento, aproveitando-se das experiências provenientes do senso comum para poder contextualizálas para a aprendizagem científica.

BULWIK (2004) compartilha do mesmo pensamento ao articular o processo educativo à autonomia do aluno, revelando que a experiência profissional do professor é tão importante no processo avaliativo quanto na organização pedagógica de atividades que suscitem responsabilidades por parte dos alunos e harmonia no relacionamento entre ambos.

Professores e alunos, ao se relacionarem harmoniosamente, transferem um ao outro o desejo de alcançar o saber, movidos pela curiosidade de obterem conhecimentos como recursos estratégicos para resolução de determinadas situações que se apresentarem em suas vidas, pois além de conhecerem a si próprios também passam a reconhecer mais facilmente as características típicas do meio em que vivem (SILVA \& NÚÑEZ, 2002).

O professor que realiza com prazer e amor suas atividades profissionais contribui para a construção de uma sociedade do conhecimento mas, para isso, "(...) é necessário que as aprendizagens não sejam excessivamente simples, o que provocaria frustração ou rejeição (...)" (PELIZZARI et al., 2002, p. 40) aos conteúdos escolares, por parte dos educandos.

"(...) O próprio educador é uma ferramenta do saber do aluno. Se ele for
apaixonado pela sua área do conhecimento e for capaz de encantar, o aluno
poderá, talvez, perceber que existe algo pelo qual alguém de fato se
interessou e que talvez possa valer a pena seguir no mesmo caminho. Mas
se essa não for a realidade vivida pelo professor todo seu corpo estará
dizendo o contrário e o aluno provavelmente terá aquele conhecimento
como algo apenas a ser cumprido, porque a mente humana é capaz de
fazer leituras bastante profundas dos detalhes aparentemente
insignificantes, mas que certamente têm um grande poder de semear
profundos significados (...)" (PELIzZARI et al., 2002, p. 41)."

Portanto, o professor deve ser capaz de promover o aprofundamento dos conhecimentos científicos e das transformações advindas do processo de globalização através de ações reflexivas e interativas, porém, se esta prática for apenas de memorização e não de construção significativa do conhecimento, perde-se completamente o sentido de troca de experiências vividas. Desse modo, a integração entre os pares origina uma aprendizagem dita colaborativa, pois prevê um aprendizado em que os participantes interagem em um processo dialógico baseado nas competências e habilidades dos sujeitos 
mais experientes, influenciando a ressignificação da linguagem utilizada pelos sujeitos menos experientes (GEROSA et al., 2003).

Conseqüentemente, a aprendizagem colaborativa deve ocorrer em um ambiente adequado ao trabalho coletivo, em que os sujeitos participantes dos processos de ensino e aprendizagem colaboram para o desenvolvimento significativo da sociedade. Assim, o desenvolvimento intelectual do educando acontece no momento em que a aprendizagem adquire um sentido, ou seja, os educandos encontram nos educadores prazer em realizar suas atividades, motivando-os à construção do conhecimento científico.

PEREIRA et al. (2007), RIBEIRO \& JUTRAS (2006) e VEIGA \& WEIDUSCHAT (2004) identificaram em seus trabalhos que as ações dos professores interferem nos resultados de aprendizagem obtidos pelos alunos, onde o pensar e o sentir são ações indissociáveis do vínculo existente entre professores e alunos na relação educativa. Os resultados desses trabalhos mostram que as ações dos professores e sua capacidade de desenvolverem estratégias pedagógicas dinâmicas e criativas podem interferir positivamente na aprendizagem escolar, porque estimulam a criação de um clima de compreensão, confiança, respeito e motivação, proporcionando aos alunos uma participação efetiva nas atividades propostas.

Em relato feito por professoras (CASTILHO et al., 1999, p. 15), a respeito de suas práticas em sala de aula, elas mencionaram que planejavam suas atividades de maneira mais objetiva e adequada a realidade de seus alunos, seguindo exemplos de professores que haviam marcado positivamente suas vidas:

“(...) procurávamos implementar, em nossas aulas, atividades mais interessantes e diversificadas, usando recursos didáticos variados como, por exemplo, demonstrações experimentais, vídeos, aulas mais dialogadas, trabalhos em grupos menores, etc (...)".

Uma pesquisa qualitativa abordando a influência do professor no processo de ensino aprendizagem, realizada com 24 alunos do $3^{\circ}$ ano do ensino médio com faixa etária entre 16 e 50 anos, em uma escola pública estadual de um bairro de Cascavel, Paraná (PEREIRA et al. 2007, p. 9) e a Dissertação de Mestrado de ULLER (2006, p. 68 e 78), que se refere a uma pesquisa também de abordagem qualitativa e interpretativa realizada com 15 alunos de uma escola pública e 42 alunos de uma escola particular do município de Ponta Grossa, Paraná, apresentam falas de alguns alunos sobre suas experiências escolares. Essas falas mostram como as relações educativas estabelecidas entre professores e alunos podem interferir no aspecto cognitivo dos educandos, destacando o papel de alguns educadores que se preocupam com seus alunos e consideram que estes não são desprovidos de sentimentos. Por exemplo: 
"Foi muito bom ter ganho aquela caixa de chocolate, pois me entusiasmei e até hoje minhas notas de Química são muito boas. Valeu a pena o incentivo da professora." (ULLER, 2006, p. 68)

"(...) como é bom termos professores que amam o que fazem, pois nos fazem amar o que eles amam." (ULLER, 2006, p. 78)

"A primeira vez que tive problemas foi no ano de 2006 com uma professora dessa escola, desde que aconteceu o fato não consigo mais aprender a matéria, tenho dificuldade, criou uma barreira, fico tensa na aula dessa professora." (PEREIRA et al., 2007, p. 9) ${ }^{8}$

"Quando a gente tem uma boa relação com o professor a aprendizagem também é boa, mas uma vez não gostei do jeito que a professora dava aula, e por isso não aprendi nada o ano inteiro". (PEREIRA et al., 2007, p. 9) ${ }^{8}$

Em suas considerações, VEIGA \& WEIDUSCHAT (2004) e do mesmo modo ULLER (2006), admitem que, para uma aprendizagem realmente expressiva, a construção do conhecimento está intimamente relacionada à cognição e ao relacionamento dos alunos com o seu grupo, sendo o educador o grande responsável nesse processo de inter-relação, considerando que o aluno traz alguma coisa de si mesmo para o ambiente escolar, pois “(...) não são como uma tábula rasa ou um recipiente vazio que o professor deve preencher (...)" (PELIZZARI et al., 2002, p. 41).

Os alunos devem manifestar suas opiniões sem medo de serem ignorados pelo professor, pois é na consideração às diferenças dos educandos que se concretiza a aprendizagem e se conquista o respeito dos alunos. Nesse contexto, a atitude do professor contribui, facilitando ou criando uma barreira à aprendizagem. O professor, "(...) líder e organizador do coletivo (...)" (GIORDAN, 1999, p. 10), precisa que os alunos estejam do seu lado, pois, se estiverem contra, essa hostilidade será um obstáculo a qualquer conteúdo a ser interiorizado (PEREIRA et al., 2007).

\footnotetext{
${ }^{6}$ Relato de um aluno com dificuldades e desinteresse pela disciplina de Química. A professora ao ver sua apatia o desafiou a ter bons resultados na avaliação. $O$ aluno atingiu a meta estabelecida e a professora cumpriu sua promessa deixando o aluno muito entusiasmado com o fato.

${ }^{7}$ Relato de uma aluna que descobriu o verdadeiro sentido da história através da atuação em sala de aula da professora desta disciplina.

${ }^{8}$ Relato de duas alunas ao responderem uma questão sobre sua trajetória escolar e se houve algum fato marcante em sua relação com sua professora de Química que poderia ter influenciado sua aprendizagem.
} 


\subsection{O conhecimento Químico no contexto da educação escolar: a experimentação como motivadora ao desenvolvimento de conceitos científicos}

$\mathrm{Na}$ interação dos aspectos cognitivos e relacionais é que os educandos se comunicam com o meio exterior ao ambiente escolar e percebem o interesse do educador pela aprendizagem de seus alunos, sabendo ouvi-los e auxiliá-los na busca por novas descobertas e pelo desejo de continuidade da aprendizagem, comprometendo-se com a formação de indivíduos com valores que contribuam para a transformação da sociedade (ELEUTÉRIO, 2006, PEREIRA et al., 2007 e RIBEIRO, 2003).

Desse modo, percebe-se que as pessoas libertam suas potencialidades e conseguem articulá-las com o meio em que vivem quando são capazes de se relacionarem autonomamente com seus semelhantes, respeitando suas crenças e valores. Portanto, ao se conectar com o mundo de forma a apropriar-se das informações nele presentes, o ser humano é capaz de transformar-se para melhor se adaptar, captando e apreendendo as diversidades do mundo no qual vive e interage com seus semelhantes. Assim, diversas metodologias de ensino têm sido empregadas a fim de favorecer um aprendizado significativo ao mesmo tempo em que proporcionam a capacitação dos professores através de atividades mediadas pelo diálogo com seus pares (WEIGERT et al., 2005).

RIBEIRO et al. (2003), em investigação realizada com 245 alunos do $3^{\circ}$ ano do Ensino Médio da cidade de Montes Claros, Minas Gerais (amostra casual de 58 alunos, sendo 33 da rede pública e 25 da rede particular), apresentam a opinião desses alunos sobre a motivação para aprendizagem química, propiciada por aulas práticas. Como exemplos, para nortear melhorias no ensino de Química, destacaram fatores como: aumento no número de atividades experimentais, a fim de integrar o conhecimento escolar com o conhecimento cotidiano e professores pacientes e incentivadores.

Esses autores acreditam que o aprendizado deve estar relacionado ao cotidiano para não se transformar em algo desgastante. Enfatizaram, também, que mesmo sem esses educandos entenderem o significado da Química eles a consideram muito importante na promoção de avanços e transformações das condições de vida dos homens. Também observaram, em suas investigações, que as aulas laboratoriais auxiliam no entendimento do conhecimento científico, entretanto, quando são realizadas em grandes grupos e somente como está prescrito em um roteiro deixam os alunos insatisfeitos. Dos resultados obtidos nesse estudo, identificaram que: 
1-a disciplina que os alunos da rede pública mais gostam é Biologia (26\%) e as que menos gostam são da área de exatas; já na rede particular a disciplina de maior preferência é Química (42\%) e a que menos apreciam é Geografia (5\%);

2-de um modo geral, os alunos gostam de estudar Química (59,1\% da rede pública e 90,5\% da rede particular de ensino), justificando-se, para tanto, com a didática que o professor utiliza em suas aulas;

3-todos os alunos afirmaram que participar de uma aula prática pode ajudar na compreensão do conteúdo.

Observa-se, nesse estudo, que a maioria dos alunos da rede particular gosta mais de estudar Química do que os alunos da rede pública. Isso pode estar relacionado com o fato de que os educandos da rede particular tiveram aulas experimentais, o que não ocorreu com os alunos da rede pública. Entretanto, é satisfatória a porcentagem de alunos encontrada na rede pública que gostam de estudar Química, pois esses alunos já conseguem perceber a importância da Química na sociedade (RIBEIRO et al., 2003). Estes alunos também apresentam outros fatores que justificam o seu prazer pela aprendizagem Química, sendo eles:

aulas interessantes: $57,1 \%$ na rede particular e 31,8\% na rede pública;

professores compromissados: $28,6 \%$ na rede particular e $22,7 \%$ na rede pública;

matéria fácil: 4,8\% na rede particular e 4,5\% na rede pública.

Assim, RIBEIRO et al. (2003) concluíram que a aula experimental é um fator motivacional para a aprendizagem Química, auxiliando na compreensão dos conteúdos escolares.

CARDOSO \& COLINVAUX (2000) em estudo semelhante ao de RIBEIRO et al. (2003), apresentam resultados obtidos em questionamento feito a 157 alunos (56 alunos de $8^{\underline{a}}$ série do Ensino Fundamental e 101 alunos de 3o ano de Ensino Médio, provenientes de escolas públicas e privadas), procurando identificar a relação motivacional desses alunos para a aprendizagem química. Esses autores mencionam que alguns alunos relacionam a Química somente a uma profissão e deixam de percebê-la como um corpo de conhecimentos necessários à construção de uma visão de mundo ou mesmo à compreensão das novas tecnologias que estão sendo desenvolvidas.

A pesquisa de CARDOSO \& COLINVAUX (2000) corrobora as idéias apresentadas por RIBEIRO et al. (2003), e da qual selecionamos as seguintes informações: 
Capítulo 2 - As relações colaborativas e o processo de construção do conhecimento escolar

- 72\% dos alunos afirmam gostar de estudar Química. Esse universo de alunos pesquisados se justificou através das relações que "(...) a Química mantém com os fenômenos da natureza e o cotidiano (56\%)", por ser a Química “(...) fonte de conhecimentos que exige raciocínio, compreensão e pouca memorização (18\%)", as “(...) aulas práticas são de fácil assimilação (10\%)" e o “(...) conhecimento químico é útil em suas vidas e futuras profissões (16\%)".

- os outros $25 \%$ dos alunos entrevistados que disseram não gostar de estudar Química e se justificaram afirmando que "(...) ela é apresentada com uma quantidade excessiva de assuntos ensinados de maneira confusa e abstrata (53\%)"; outros disseram que "(...) não se interessam porque já sabem o suficiente e quando necessário recorrem a revistas especializadas e que esta área de conhecimento não será útil em sua futura profissão (17\%); também alegaram "(...) dificuldades em entender e assimilar os conceitos químicos (22\%) e por fim “(...) os conhecimentos químicos são difíceis de entender, apesar de serem úteis e importantes (8\%).

Nas análises feitas por CARDOSO \& COLINVAUX (2000) e RIBEIRO et al. (2003), a maior parte dos alunos afirmam gostar de estudar Química, considerando a aula prática e a presença em sala de aula de um professor interessado, os motivos pelos quais se interessam pela aprendizagem dos conteúdos apresentados. Para eles, o estudo da Química é indispensável para a vida, pois é fonte de conhecimentos que exige raciocínio, compreensão, pouca memorização, e por estar acompanhada de aulas práticas, facilitam a assimilação de conceitos.

Em pesquisa realizada por ROSA \& SCHNETZLER (1998), quanto às concepções alternativas de educandos do Ensino Médio sobre transformações químicas, as autoras constataram que o estudo da Química, quando praticado através de processos experimentais, proporciona melhorias nos processos de ensino e aprendizagem facilitando a formação de conceitos científicos. PACHECO (1997) complementa essa idéia afirmando que “(...) deve-se dar ao aluno a oportunidade de expressar suas concepções dos fenômenos de forma direta, experimental, ou de forma indireta, através de registros desses fenômenos (...)."

GIORDAN (1999, p. 10) cita em suas pesquisas relatos de alunos e professores que “(...) atribuem à experimentação um caráter motivador, lúdico e vinculado aos sentidos, aumentando a capacidade de aprendizado, pois funciona como meio de envolver o aluno nos temas em pauta (...)". Esses fatores implicam um maior envolvimento dos alunos nas aulas de Química, por apresentarem-se de maneira dinâmica, criativa e contextualizada, explorando as potencialidades dos indivíduos envolvidos na aprendizagem científica. Os 
processos investigativos, quando aplicados como estratégias facilitadoras da aprendizagem, requerem o exercício da criatividade para a solução das situações apresentadas, levando os estudantes a se interessarem pelo ensino contextualizado. Como conseqüência dessa prática, o aluno utiliza-se de uma linguagem recentemente constituída em sua estrutura cognitiva, a qual vai se ampliando pelo seu envolvimento em atividades experimentais empregadas com a finalidade de construção coletiva do conhecimento.

CARDOSO \& COLINVAUX (1999) e GALIAZZI \& GONÇALVES (2004) afirmam que, ao integrar o cotidiano ao conhecimento escolar, os alunos desenvolvem seus primeiros conhecimentos científicos favorecendo o desenvolvimento da linguagem e facilitando a compreensão dos fenômenos que nos rodeiam. Desse modo, o educador deve utilizar-se do trabalho experimental para contextualizar situações que sejam familiares aos educandos. Essa estratégia pedagógica envolve a construção de argumentos favorecidos pelo diálogo, em discussões em grupo e no coletivo da sala de aula. Nesse contexto, cada um tem um papel fundamental para a aprendizagem, questionando os entendimentos sobre a experimentação para enriquecer suas próprias teorias.

CALDAS \& HÜBNER (2001) ratificam esses argumentos em pesquisa realizada com 75 participantes, sendo 50 alunos e 25 professores de Educação Infantil e Ensino Fundamental de uma escola particular, de alto padrão, localizada na cidade de São Paulo. Nessa pesquisa, esses autores identificaram que o interesse e a motivação dos alunos pelo aprender na escola diminuem gradativamente com o avançar nas séries escolares.

O motivo descrito pelos autores, para o crescente desinteresse pelo aprendizado, pode estar relacionado ao fato dos educadores não apresentarem atividades motivadoras e desafiadoras para a conquista do novo e à falta de subsídios que cercam os educandos, dificultando seu processo de interação com o aprender, tornando a construção de novos conhecimentos algo exaustivo. Nessa mesma pesquisa, os autores se deparam com as seguintes situações de envolvimento com a aprendizagem escolar:

$80 \%$ dos alunos de Educação Infantil a consideram como muito legal e os $20 \%$ restante a consideram apenas como legal. Os professores das séries iniciais da escolarização corroboram dessa mesma visão, ao indicarem que $100 \%$ de seus alunos gostam muito da aprendizagem que ocorre na escola.

já $80 \%$ dos alunos da série final do Ensino Fundamental consideram este tipo de aprendizagem como legal, $10 \%$ como muito legal e $10 \%$ como pouco legal. Esse fato indica que alguns alunos, apesar de seu desencantamento, ainda gostam das aprendizagens realizadas no âmbito escolar. Contudo, os professores participantes dessa pesquisa e que ministram aulas nessa mesma etapa de ensino da Educação 
Básica, acreditam que $80 \%$ desses alunos consideram pouco legal a aprendizagem nesse espaço educacional.

Esses resultados vêm ao encontro às conclusões de CARDOSO \& COLINVAUX (1999) e RIBEIRO et al. (2003), que apontam o relacionamento entre professores e alunos em um ambiente agradável e interessante como fator determinante da motivação e interesse pelo aprender na escola. Esses trabalhos mostram que grande parte dos alunos gosta mais de uma disciplina ou menos de outra, por causa do professor.

Em vista disso, o professor deve adotar uma postura na qual trace um trajeto epistemológico que se inicie do próximo para o remoto e do concreto para o abstrato. Logo, a construção de conceitos deve pautar-se, em parte, nas observações que os alunos fazem no âmbito macroscópico, para depois articularem suas concepções a conceitos menos inclusivos e nas relações que conseguem estabelecer entre os saberes pré-estabelecidos em suas mentes e os que vierem a se estabelecer através do contato com os outros.

Conforme afirmações de SILVA \& NÚÑEZ (2002), o trabalho experimental pode promover a ressignificação de conceitos por converter-se numa atividade cognoscitiva criadora, investigativa e produtiva, mobilizando conhecimentos e habilidades nos alunos que vão se enredando gradativamente.

KRASILCHIK (1987), em estudos realizados na década de 1980, identificou alguns problemas relacionados ao Ensino de Ciências e que, mais de 20 anos depois, ainda se encontram presentes nas escolas brasileiras. O mesmo foi relatado em artigo escrito por SCHNETZLER (2004). Dentre os diversos fatores apresentados, têm-se:

a memorização de fatos como fórmulas, nomes, descrições de fenômenos;

falta de vínculo com a realidade dos alunos, tornando o ensino irrelevante e sem significado por estar descontextualizado;

inadequação das atividades propostas devido ao desajustamento com o desenvolvimento intelectual dos educandos;

passividade dos alunos em aulas ministradas de forma expositiva e autoritária, descaracterizando a importância da atividade dos alunos na busca pela formação de novas idéias.

Assim sendo, para que a escola se torne interessante e transforme os alunos em cidadãos reflexivos e atuantes na sociedade, é fundamental que o ambiente da sala de aula seja intelectualmente ativo e cooperativo, por meio de estratégias de ensino pautadas em suas capacidades cognitivas, como o diálogo e o relacionamento com seus semelhantes. 


\subsection{A socialização do saber e o desenvolvimento intelectual dos sujeitos envolvidos nos processos de ensino e aprendizagem: o professor e 0 cotidiano escolar para a construção do conhecimento científico}

O conhecimento se transforma cotidianamente, pois a todo o momento o ser humano relaciona-se com seus semelhantes e suas experiências passam pelas mais variadas formas de pensamento e, no processo de construção coletiva do conhecimento, suas operações mentais se adaptam à nova realidade integrando os novos conhecimentos aos já pré-existentes, ocasionando um acréscimo ao seu repertório de informações.

CUEVAS et al. (2004), relatam em pesquisa realizada com alunos de Ensino Médio, que a ação mediadora do professor pode influenciar diretamente a aprendizagem dos educandos, visto que, quando o professor realiza um processo investigativo sobre concepções alternativas de seus alunos o faz com o objetivo de identificar suas idéias prévias a respeito do conceito que será abordado.

A partir dessa identificação o educador poderá organizar sua aula de forma a colaborar com a ressignificação das concepções presentes na estrutura cognitiva dos educandos. Dessa forma, a ação colaborativa do professor, no processo de formação de conceitos, pode contribuir para melhorias nos processos de ensino e aprendizagem.

FERREIRA \& SANTOS (2008) concordam com o relato de CUEVAS et al. (2004), ao mencionarem em seus estudos que a mediação do professor, exercida no processo colaborativo de construção do conhecimento, possibilita ao aluno a aquisição de competências que mobilizam suas funções cognitivas superiores. Essas funções cognitivas se expressam em atividades que requerem a interação entre alunos e professores a fim de contribuírem para o aprendizado de seus pares a partir do compartilhamento de suas experiências com o grupo.

\footnotetext{
"O professor deve ser o articulador desses processos de compartilhamento e síntese do conhecimento, criando situações colaborativas favoráveis, propiciando aos alunos possibilidades múltiplas e multiformes de atuarem de forma crítica e imaginativa, estimulando-os na resolução de problemas, na superação de conflitos cognitivos e no processo criativo." (FERREIRA \& SANTOS, 2008, p. 289)
}

Em vista disso, compreende-se que a ação socializante da escola, para construção coletiva do conhecimento, objetiva o desenvolvimento intelectual dos indivíduos e o seu aprimoramento nas relações intercomunicativas e colaborativas, existentes não só nos ambientes escolares como também fora deles, primando pela superação de desafios e conflitos encontrados na trajetória da aprendizagem significativa. 
RAMOS (2007, p. 1) participa desse pensamento ao escrever que “(...) a colaboração é uma ação social, na qual pessoas compartilham objetivos e aprendem juntas visando superar desafios e construir conhecimentos". BATISTA (2006, p. 4) corrobora o pensamento de RAMOS (2007) ao dizer que "(...) a colaboração se dá na interação, ao mesmo tempo em que a interação se dá na colaboração, no acoplamento estrutural entre sujeitos, e não no aglomerado de pessoas que trabalham individualmente."

Com a intenção de refletir sobre as formas de colaboração, no processo de aprendizagem de alunos do Ensino Fundamental, RAMOS (2007) realizou uma pesquisa qualitativa com 43 alunos de oitava série de uma escola pública estadual de Florianópolis, Santa Catarina. Nessa pesquisa, a autora observou que $89,06 \%$ dos alunos dessa escola preferem realizar seus trabalhos escolares em grupo e em sala de aula.

As justificativas apresentadas pelos alunos destacam o favorecimento das relações sociais para a aprendizagem escolar, sendo que o convívio com o grupo pode auxiliar na aprendizagem de conteúdos, porque alguns alunos sentem maiores dificuldades em compreender os objetivos para a realização das atividades propostas. Assim, eles acreditam que as relações colaborativas com parceiros mais experientes podem facilitar a compreensão dos meios de desenvolvimento das tarefas.

\begin{abstract}
"As atividades colaborativas estruturam as relações sociais e os papéis dos sujeitos no processo educativo, pois os alunos passam a ser responsáveis pela organização do trabalho, buscam fontes alternativas de pesquisas e têm o foco nas contribuições dos integrantes do grupo. O professor, por sua vez, passa a ser fundamental no planejamento da atividade e na concepção da proposta, pois durante o desenvolvimento da atividade orienta os alunos e os auxilia na resolução de suas dúvidas." (RAMOS, 2007, p. 6)
\end{abstract}

Contudo, RAMOS (2007, p. 6) ressalta que nas atividades em grupo em que ocorre a divisão de trabalho observa-se que o aluno com dificuldades de aprendizagem "(...) acaba ficando alheio ao processo, ou sendo responsável por fazer atividades que exigem pouca capacidade de argumentação teórica (...)". Assim, no processo de formação de conceitos os alunos que têm baixo desenvolvimento intelectual ficam limitados a executar tarefas mais simples, não ocorrendo a Zona de Desenvolvimento Proximal, porque não passam por conflitos cognitivos e ficam encarregados de executar apenas atividades para as quais já construíram significado, em que não se exige colaboração entre os pares para sua execução.

De acordo com RAMOS (2007, p. 6), “(..) a zona de desenvolvimento proximal não ocorre, pois o aluno não é desafiado a se superar, a aprender ou a aprimorar novas habilidades e construir novos conhecimentos." 
LIMA et al. (2007, p. 129) divergem desse tipo de divisão do trabalho em grupo, pois afirmam que em um processo de aprendizagem colaborativa "(...) cada aluno do grupo é responsável não somente por aprender o que está sendo ensinado, mas também por ajudar o seu colega, criando uma atmosfera de realização (...)". Cada um vem para o grupo com diferentes habilidades que precisam ser consideradas durante a formação dos grupos, através da comunicação e percepção de conflitos que podem interferir na interação entre os alunos. Desse modo, cabe ao professor perceber quais são as peculiaridades de seus alunos, organizando-os de forma a motivá-los à construção coletiva do aprendizado.

Nesse contexto, as experiências cotidianas dos envolvidos no processo ensinoaprendizagem para a formação de conceitos, no universo escolarizado, devem ser valorizadas, pois dessa forma se institui um conhecimento acessível aos estudantes e adaptado aos conteúdos escolares (SCHAFFER, 2007, p. 21).

No constante processo de adaptação ao meio, observa-se que o saber construído também se modifica, ampliando o repertório de informações decorrentes da evolução da sociedade. Essa amplitude de informações culturalmente estabelecidas entre os indivíduos se inicia muito antes dos educandos começarem a freqüentar o ambiente escolar, entretanto, é nesse meio que o conhecimento se desenvolverá para mediar a transformação da sociedade.

NEHRING et al. (2002) comentam que, muitas vezes, os conteúdos escolares desvinculados da realidade dos educandos são apresentados pelos professores de forma fragmentada, como se o conhecimento científico transmitido aos alunos no ambiente escolar não apresentasse interpretações do mundo real. De tal modo que “(...) ensinar Ciências se configuraria como um processo no qual a exposição dos alunos a situações de conflito seria o caminho para possibilitar a superação das concepções prévias e construção de conceitos científicos (...)" (MACHADO, 2004, p. 28).

O alcance desses conhecimentos ocorre, como dizem COSTA \& MOREIRA (2001), através de resolução de problemas, permitindo que os educandos se envolvam na readequação das concepções prévias presentes em sua estrutura cognitiva para consolidar a aprendizagem de conceitos científicos. Para GEHLEN et al. (2008, p. 67) quando se trazem, para dentro da escola “(...) situações contextuais e complexas, problematizando-as, fica evidente a necessidade de novos conhecimentos, o que cria um ambiente favorável à abordagem e significação dos conceitos científicos. 
Portanto, articular os conteúdos escolares com atividades relacionadas à resolução de problemas significativos impulsiona o desenvolvimento intelectual dos educandos, por meio de uma linguagem construída continuamente no contato com o meio social.

A linguagem adquirida pelos educandos no espaço da educação escolar e desenvolvida através da interação com seus semelhantes como meio de comunicação, permite que os alunos apropriem-se de conhecimentos que poderão facilitar o seu desenvolvimento cognitivo pela formação de conceitos mais amplos, que abarquem tantas informações que lhes permitam caminhar por entre as dificuldades e conflitos presentes no processo educacional.

A transformação do intelecto ocorre pelos usos que se faz da linguagem, a qual é indispensável à formação de conceitos que vão se formando a partir do conhecimento cotidiano até se tornarem significativos e estabelecidos culturalmente, devido à necessidade de sua utilização pela sociedade.

Então, a partir do momento que os conceitos científicos se tornam significativos também para os educandos, é porque já apresentam sentido para cada um. Nesse caso, a escola, como integradora e facilitadora da construção do conhecimento científico de seus alunos, inicialmente por meio de conceitos cotidianos alternativos, espontâneos, ou préconceitos (NÉBIAS, 1999) deve ser mais do que uma mera transmissora de informações, portanto, deve considerar os saberes prévios dos envolvidos na transformação da sociedade, desenvolvendo nos educandos e educadores competências e habilidades necessárias para o seu convívio no mundo globalizado.

Partilham desse pensamento SCHMIDT et al. (1998, p. 16), ao escreverem sobre a prática pedagógica de professores reflexivos e seu processo de formação profissional e atuação no ambiente escolar.

"A vida hoje na escola, na sala de aula, tem que ser muito mais do que a
transmissão de um conteúdo sistematizado do saber. Deve, com certeza,
incluir a aquisição de hábitos e habilidades e a formação de uma atitude
correta frente ao próprio conhecimento, uma vez que o aluno deverá ser
capaz de ampliá-lo e reconstruí-lo quando necessário, além de aplicá-lo em
situações próprias do seu contexto de vida. Sendo assim, é preciso que o
professor enfrente o desafio de compreender os tempos novos para abarcar
os anseios das novas gerações e auscultar os rumos do futuro."

A prática de ensino investigativa proporciona ao professor a observação das concepções prévias dos educandos contextualizando o conteúdo a ser ensinado, porém como dizem ROSA et al. (2001, p. 39), “(...) é importante não perder de vista a abordagem de saberes científicos (...)" para que as aulas não fiquem somente na discussão do conhecimento oriundo do senso comum. Assim, o planejamento das aulas permite que o 
professor organize o grupo de alunos de forma a promover a colaboração entre eles por meio do diálogo, pois numa aula colaborativa a integração é relevante para o desenvolvimento da linguagem científica.

\begin{abstract}
“(...) as mudanças previstas por um trabalho colaborativo têm poucas chances de se consolidar, se não ocorrer o compartilhamento dos problemas e se não nos dispusermos a experimentar mudanças reais em nossas práticas escolares. Ou ainda, se não acreditarmos e aceitarmos o processo de desenvolvimento profissional através da problematização de conceitos científicos e tecnológicos, assumindo-os como fundamentais." (ABEGG \& BASTOS, 2005, p. 5).
\end{abstract}

Ao planejar suas aulas, o professor prevê o conteúdo a ser trabalhado, porém é no cotidiano da sala de aula que realmente poderá observar e refletir sobre o melhor meio para auxiliar seus alunos em seu desenvolvimento intelectual. Assim, a prática reflexiva empregada nas aulas de Química proporciona uma constante readequação da metodologia utilizada pelo professor, conforme as reais condições materiais emergentes na ação educativa (ABEGG \& BASTOS, 2005). Assim sendo, o educador pode planejar ou até mesmo replanejar suas aulas a partir da realidade concernente a vida dos educandos e do mundo que os cerca.

Logo, o importante no contexto educacional é instrumentalizar os educandos através da complementação de seu repertório de informações, ensinando-os a pensar e não somente a reproduzir mecanicamente o conhecimento oferecido pela sociedade, tornando a educação uma ferramenta de construção de instrumentos para a resolução de problemas, a partir do convívio com outras pessoas.

Nas pesquisas exploradas para construção desta argumentação, observa-se a importância que deve ser impressa ao conhecimento que os alunos trazem de suas vidas para o ambiente escolar e a importância de se estabelecer um processo de aprendizagem que se constrói “(...) através de interações complexas e dinâmicas, articuladas pelo professor, que abrangem mediações e trocas sócio-culturais diversificadas, nos contextos de dentro e fora da escola" (KINALSKI \& ZANON, 1997, p. 15).

Por conseguinte, ensino investigativo e colaborativo, pautado em atividades experimentais que motivam os alunos à aprendizagem científica (KRASILCHIK, 1987; TITONI \& DEL PINO, 2008), não se restringe a temáticas do cotidiano, mas envolve dinâmicas que relacionam "(...) o cotidiano com as ciências, na potencialização de aprendizagens relevantes (...)" (KINALSKI \& ZANON, 1997, p. 16).

GOMES (1998) encontrou resultados semelhantes aos de TITONI \& DEL PINO (2008) e ROSA et al. (2001), ao realizar sua pesquisa em aulas de Química para alunos de um curso 
profissionalizante, em Belo Horizonte, Minas Gerais. Em sua investigação, considerou a relevância das idéias prévias dos educandos e sua participação ativa na ressignificação de conceitos, ao relatar em um artigo suas reflexões enquanto professor.

Suas observações, realizadas a partir de atividades investigativas, colaborativas e relacionadas ao cotidiano dos alunos, versaram a respeito de concepções desses educandos sobre a validade de se estudar Química. As propriedades específicas e transformações dos materiais (no âmbito macroscópico) foram os eixos norteadores do curso que ministrou. Das considerações dos alunos sobre a relevância de estudar Química (p. 15), ressaltamos as elencadas na seqüência:

•"(...) oportunidade de aprenderem assuntos cobrados no vestibular (...)";

•"(...) formalidade burocrática (...)”;

- "(...) cada disciplina estudada pode contribuir para a formação de um profissional mais completo, uma das exigências atuais do mercado de trabalho (...)"

Ao observar essas considerações, GOMES (1998, p. 18) percebeu a necessidade de reavaliar sua prática, bem como a relevância dos conteúdos abordados, a partir da “(...) construção de propostas e de práticas que sejam mais reflexivas, interativas, críticas e conscientes, efetivamente capazes de contribuir para a melhoria da formação escolar".

KINALSKI \& ZANON (1997), ao realizarem uma atividade investigativa com 22 alunos de oitava série de uma escola localizada em ljuí, no Rio Grande do Sul, propuseram o tema "leite" para suscitar concepções sobre materiais e substâncias. Para tanto, fizeram aos alunos questões como, "O leite é uma substância pura, ou é uma mistura de substâncias? Por quê?", "O que você entende por substância?", "De que é constituído o leite?”, "O que existe no leite?". Como exemplos das observações das autoras para essas questões têmse: "Os alunos envolveram-se intensamente, mostrando-se atentos, questionadores, com dúvidas, interessados em obter informações, colaborando ativamente nos procedimentos, atentos em comentar/entender os processos envolvidos em cada passo" (p. 17) ${ }^{9}$.

As respostas fornecidas pelos alunos participantes da pesquisa foram: "O leite não é uma substância única, sua aparência pode ser uniforme, mas é constituído por várias substâncias" (p. 18); "Eu aprendi várias coisas sobre o leite, como por exemplo, que o leite não é uma substância pura, ele é uma mistura, composta por nutrientes como gordura, água e açúcar, assim podemos separar essas substâncias que o compõem" (p. 18); "Estas análises do leite me fizeram pensar no quanto ainda tenho de aprender sobre o mundo que nos cerca, e do que, e como, a matéria é composta, e que talvez pudéssemos modificar a

${ }^{9}$ Observação das autoras KINALSKI, A.C. \& ZANON, L. B. (1997). 
matéria das coisas e criar novos conceitos de alimentação e alimentos a respeito do que uma experiência prática pode desencadear na mente de uma aluna, o fato é que a complexidade da matéria é por sua própria natureza complexa." (p. 18).

As autoras observaram que os alunos recorreram a conhecimentos desenvolvidos em anos anteriores para responderem a essas questões. Após essa constatação, procedeu-se a uma série de experimentos a fim de que os alunos pudessem observar os vários componentes presentes no leite e as condições que favorecem a produção de seus derivados, o que os levou a se envolverem mais nas atividades, criando concepções próprias sobre transformações químicas, substâncias, misturas e seus processos de separação e rendimento na produção do queijo.

Enfim, conseguiu-se que os alunos se interessassem pela aprendizagem química, através da motivação encontrada em procedimentos experimentais que levam educandos e educadores a se manifestarem através de discussões e questionamentos em uma aula mais dinâmica e interativa, que conduz à articulação dos conhecimentos químicos ao cotidiano dos alunos (KINALSKI \& ZANON, 1997).

BORTOLAI \& REZENDE (2006), ao realizarem pesquisa de cunho investigativo, com alunos de Ensino Médio, sobre a identificação de evidências em sistemas em transformação, chegaram à conclusões semelhantes às de KINALSKI \& ZANON (1997), ao perceberem que o grupo de alunos participantes de sua pesquisa também estava se utilizando de conhecimentos construídos em anos anteriores para justificar 0 reconhecimento dos sistemas em transformação. Entretanto, BORTOLAI \& REZENDE (2006) acreditam que isso significa que "(...) os alunos estão sendo capazes de abstrair, elaborando e propondo soluções(...)", porém apresentando confusões entre termos como "puro" e "natural", o que revelou que a maioria ainda não tinha construído o conceito de substância.

TITONI \& DEL PINO (2008), a exemplo de GOMES (1998), KINALSKI \& ZANON (1997) e outros, utilizaram-se de um tema motivador em aulas experimentais para a contextualização e construção de conceitos científicos.

Nessa pesquisa, os conceitos abordados foram solubilidade e substâncias polares e apolares. A pesquisa foi realizada com 33 alunos de $2^{\underline{a}}$ série de Ensino Médio, no município de Santa Rosa do Sul, Santa Catarina. A metodologia de análise empregou pré e pós-testes perante a atividade experimental de verificação de teor de álcool na gasolina, a fim de averiguar as idéias prévias dos educandos. TITONI \& DEL PINO (2008) perceberam que esse tipo de estratégia de natureza investigativa possibilitou: 
- aprendizagens mais significativas e completas comparadas com as idéias prévias dos alunos;

- ampla abordagem e discussão de conceitos como: concentração em porcentagem de volume, densidade, solubilidade, misturas, polaridade, petróleo;

- que os estudantes reestruturassem suas compreensões sobre os fenômenos em estudo, bem como, a utilização de argumentos fundamentados em conceitos estruturantes do conhecimento químico;

- trabalhar, em sala de aula, conhecimentos socialmente relevantes, que possam se integrar à vida do aluno, a fim de que ele possa estabelecer ligações com outros campos do conhecimento;

- aumento da participação e interesse dos alunos, gerando uma oportunidade dos mesmos melhorarem a formação em relação a sua cidadania, pela oportunidade de trabalhar temas inseridos no seu cotidiano.

Para encerrar essa investigação, os autores aplicaram questionário avaliativo das situações didáticas aos alunos, os quais expressaram sua satisfação com as seguintes falas: "(...) as aulas práticas favoreceram nosso conhecimento, foram bastante construtivas (...)"; "(...) a gente aprendeu realizando experimentos e também pesquisando (...)"; "(...) com as experiências aprendemos muito, era uma aula diferente, nós os alunos fazíamos a experiência (...)"; "(...) as atividades em grupo sempre favorecem a aprendizagem individual. O compartilhamento de idéias foi bastante interessante (...)”; "(..) As pesquisas realizadas ampliaram nosso conhecimento e empregamos grande importância a elas (...)"; "(...) ampliou o nosso conhecimento, pois nós aprendemos muito com os experimentos e os pós-testes. Assim nós discutimos sobre os assuntos da experiência transmitindo o conhecimento um para o outro (...)"; "(...) é completamente mais fácil trabalhar em equipe do que individualmente, pois podemos compartilhar o conhecimento com os outros membros do grupo (...)" (TITONI \& DEL PINO, 2008, p. 9 e 10).

Por fim, os autores aqui citados concordam sobre a relevância do trabalho experimental como mais uma estratégia facilitadora da construção do conhecimento, levando o aluno a expandir seu raciocínio e utilizar-se de seu repertório de signos, até que possua atributos o suficiente para se tornar um símbolo a ser aproveitado, significativamente, como mais um instrumento de linguagem que possibilita a comunicação entre os indivíduos participantes da sociedade como um todo. 


\section{Capítulo 3}

\section{O PROQUIM como}

\section{Material Instrucional}

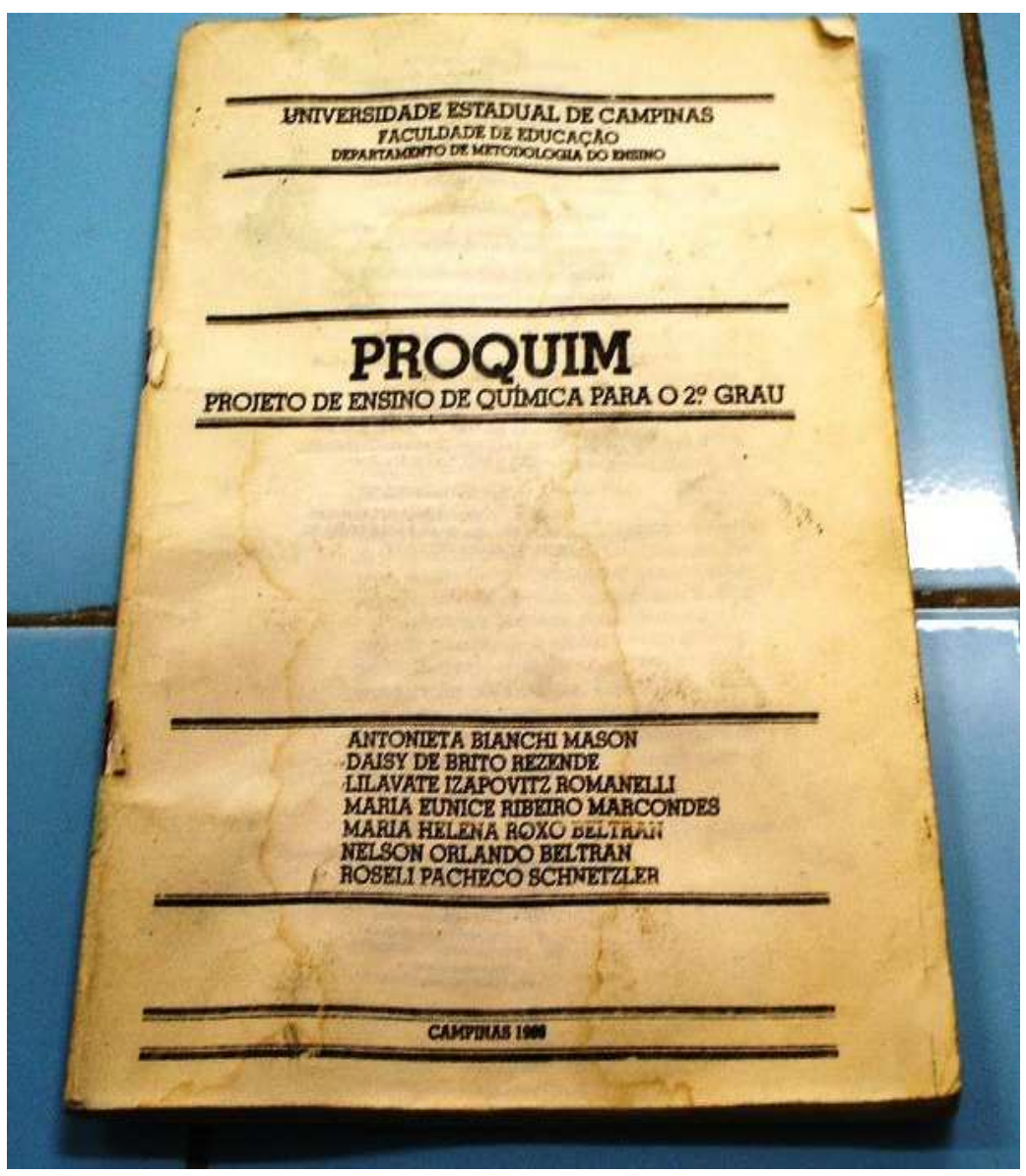




\subsection{O PROQUIM e a Teoria da Aprendizagem Significativa de David Ausubel}

O PROQUIM: Projeto de Ensino de Química para o $2^{\circ}$ grau (MAZON et al., 1986) ${ }^{10}$ é um material didático que foi desenvolvido na década de 1980, com apoio de Instituições governamentais (BELTRAN, 1987), tendo por objetivo o desenvolvimento de projetos de melhoria na qualidade do ensino de Ciências e Matemática (SANTOS, 2006).

Com o propósito de ser mais uma opção ao ensino de Química MARCONDES ${ }^{11}$ (2008), afirma que o PROQUIM possui “(...) características diferentes dos materiais tradicionais e está voltado para uma aprendizagem mais significativa por priorizar a formação de conceitos pelos alunos e desenvolver habilidades cognitivas de ordens superiores à memorização, oferecendo ao professor do Ensino Médio uma alternativa ao processo educativo (...)".

O uso de materiais instrucionais alternativos aos tradicionais se deve ao fato de estes se utilizarem de atividades memorísticas que, ao longo do tempo, se perdem em nossa memória. Desse modo, a escola precisou se adaptar e a aprendizagem de fatos e dados passou a ser complementada, com o ensino de conceitos mais complexos, que demandam maior reflexão para a reelaboração do conhecimento já existente.

Na década de 1980 a Proposta Curricular para o Ensino de Química no Estado de São Paulo preconizava a introdução de aulas práticas em meio a aulas expositivas, com o objetivo de colocar o aluno em contato com a realidade, contextualizando o ensino de Química na escola pública (SICCA, 1993).

Nesse período, no qual se insere a elaboração do PROQUIM, a Proposta Curricular para o Ensino de Química no $2^{\circ}$ grau, publicada pela SE/CENP, indicava os procedimentos experimentais como “(...) um momento de reelaboração do conhecimento (...)"(SICCA, 1993, p. 587) a fim de facilitar a construção de significados pelos educandos, pois como afirmam HAMBURGER \& LIMA (1988) o conhecimento não é algo fechado em si mesmo, ele deve ser construído pelo aluno através de aprendizagens mais significativas.

A aprendizagem significativa acontece quando novas informações são atribuídas a um conhecimento já existente e quando facilitado pela interação dos aprendizes com um

\footnotetext{
${ }^{10}$ Equipe de colaboradores do PROQUIM: Antonieta Bianchi Mazon, Daisy de Brito Rezende, Lilavate Izapovits Romanelli, Maria Eunice Ribeiro Marcondes, Maria Helena Roxo Beltran, Nelson Orlando Beltran, Roseli Pacheco Schenetzler.

${ }_{11}$ Questionário respondido por Maria Eunice Ribeiro Marcondes, constante do anexo A1 na página 159.
} 
material instrucional potencialmente significativo integrado a idéias relevantes existentes na estrutura cognitiva dos educandos (AUSUBEL, 2000).

Esse Projeto de Ensino de Química segue a metodologia de construção do conhecimento por descoberta dirigida ${ }^{12}$ (PELIZZARI et al., 2002, p. 39) que, segundo ROMANELI ${ }^{13}$ (2008), "(...) favorece o trabalho em grupo, superando o ensino tradicional, que massacra os alunos com um excesso de conceitos prontos e desprovidos de significados para a vida do aluno (...)". Segundo AUSUBEL (2000, p. 5) quando o aprendiz descobre o conteúdo que the está sendo apresentado ele cria “(...) proposições que representem soluções para os problemas suscitados, ou passos sucessivos para a resolução dos mesmos.

A visão construtivista (cognitivista) do trabalho em grupo, priorizado nas atividades propostas pelo PROQUIM, tem como premissa a forma como "(...) o conhecimento humano é construído (...)", através de uma aprendizagem significativa que envolve o desenvolvimento da estrutura cognitiva a partir daquilo que o aprendiz já sabe (MOREIRA, 1990, p. 50).

Dentro dessa visão cognitivista da construção do conhecimento, tanto a linguagem utilizada pelo professor como a empregada no material potencialmente significativo se tornam um facilitador da aprendizagem significativa. É através da linguagem apresentada que os aprendizes tomam contato com novas palavras e acabam por significá-las dandoIhes um sentido próprio e não meramente uma verbalização vazia.

MOREIRA (1990), ao historiar sobre a Teoria Construtivista da Aprendizagem Significativa $^{14}$ de David Ausubel, escreve que esse autor considera o aluno como centro do processo ensino-aprendizagem. Nesse caso, o professor deve propor-se a um trabalho criativo e preocupado não só com o "quê" ensinar, mas essencialmente, com o "por que" e o "como" o estudante aprende, na intenção de promover a integração dos conceitos através de diferentes processos mentais.

Na concepção construtivista de construção do conhecimento (MÜTZENBERG, 2005), sob a qual o material do PROQUIM foi organizado, o aluno possui autonomia para identificar

\footnotetext{
12 “(...) maneira como o aluno recebe os conteúdos que deve aprender: quanto mais se aproxima do pólo de aprendizagem por descoberta, mais esses conteúdos são recebidos de modo não completamente acabado e o aluno deve defini-los ou 'descobri-los' antes de assimilá-los." (PELIZZARI et al., p. 39, 2002).

${ }^{13}$ Questionário respondido por Lilavate Izapovitz Romanelli, constante do anexo A2 na página 161.

${ }^{14}$ “A aprendizagem é dita significativa quando uma nova informação (conceito, idéia, proposição) adquire significados para o aprendiz através de uma espécie de ancoragem em aspectos relevantes da estrutura cognitiva preexistente do indivíduo (...)" (MOREIRA, 1990, p. 68)
} 
suas dificuldades e desenvolver estratégias para reconhecer e decidir por si mesmo o melhor caminho para ultrapassá-las, cabendo ao professor “(...) otimizar o fluxo de informações durante o processo de ensino-aprendizagem" (SANTANA \& TEIXEIRA, 2005, p. $63)$.

\begin{abstract}
"Para aprender um conceito é necessário, então, estabelecer (...), relações significativas com outros conceitos. Quanto mais entrelaçada estiver a rede de conceitos que uma pessoa possui sobre uma área determinada, maior será a sua capacidade para estabelecer relações significativas e, portanto, para compreender os fatos próprios dessa área" (POZO, 2000, p. 22).
\end{abstract}

$\mathrm{Na}$ aprendizagem automática ${ }^{15}$ (MOREIRA, 1990, p. 66), exercida através de “(...) um ensino que incentiva a memorização, que não propicia situações de investigação, que não estimula a discussão e o confronto das idéias (...)" (BELTRAN, 1987, p. 27), é que alguns professores impõem seus significados e os alunos simulam adquiri-los passivamente. Entretanto, ao contrariar essa concepção memorística, o professor, ao ensinar, está em constante processo de construção de significados com seus alunos, permitindo que os mesmos sejam compartilhados e ressignificados por cada um com uma interpretação particular do que Ihes foi apresentado (TAVARES, 2004).

A aprendizagem automática, também chamada por POzO (2000, p. 31) de "aprendizagem memorística" é limitada por ser "(...) baseada na repetição e cópia literal da informação em nossa memória (...)". Essa técnica de ensino-aprendizagem utiliza-se de processos repetitivos das mensagens expressas nos materiais didáticos e não apresenta atividades para aprendizagem com significados para os aprendizes. A reprodução literal do material em estudo não constrói significativamente o conhecimento $e$, se os fatos memorizados não são utilizados com freqüência, acabam sendo esquecidos.

Contudo, os aprendizes, ao iniciarem uma nova aprendizagem, podem não possuir conhecimentos prévios referentes às mesmas, ou seja, pode inexistir o conceito subsunçor em sua estrutura cognitiva que servirá para ancoragem ao novo conceito. Assim, “(...) pode ser necessário aprender mecanicamente alguns conceitos relevantes, até que existam conhecimentos da nova área que sirvam de subsunçores para novas informações (...)" (MÜTZENBERG, 2005, p. 23).

Para que a construção do conhecimento se concretize de forma substantiva e não arbitrária (MAZON, 1989; PONTES NETO, 2006), deve ser criada uma situação de aprendizagem de maneira lógica e estruturada, assim, o encadeamento de idéias

\footnotetext{
15 "Aprendizagem sem atribuição de significados pessoais, sem relação com o conhecimento preexistente, é mecânica, não significativa." (MOREIRA, 1990, p. 68)
} 
apresentadas se conectará mais facilmente ao conhecimento já presente na estrutura cognitiva, entendida por Ausubel como uma estrutura hierárquica e organizada de conceitos.

Essa influência mútua ocorre entre os conceitos subsunçores ${ }^{16}$ e os atributos potencialmente significativos do novo objeto do conhecimento que se estuda os quais servem como âncoras ${ }^{17}$ para transformar, de modo particular, a capacidade da estrutura mental de cada ser humano que se utiliza dessa significação lógica para construção da própria aprendizagem (PONTES NETO, 2006 e SANTANA \& TEIXEIRA, 2005).

SCHNETZLER (1992) corrobora este pensamento ao escrever que a aprendizagem significativa se diferencia da aprendizagem mecânica por não ser oferecida ao aluno de forma arbitrária, desconsiderando seus conhecimentos anteriores, cabendo ao professor organizar os conteúdos de maneira coerente com as concepções dos aprendizes.

"As condições necessárias para que ocorra a aprendizagem significativa
são material potencialmente significativo e predisposição do aluno para
aprender de maneira significativa. Não adianta o aluno desejar a
aprendizagem significativa se o material não for relacionável com a
estrutura cognitiva existente, mas, por mais relacionável que seja o material,
a aprendizagem só será significativa se o aluno estiver disposto a relacioná-
lo de maneira significativa" (MÜTZENBERG, 2005, p. 23).

Assim, o PROQUIM - material instrucional utilizado nesta pesquisa como fonte de atividades para coleta de dados, foi desenvolvido a partir da consideração ao conhecimento prévio $^{18}$ do aluno, durante o processo de ensino-aprendizagem. Nesse material, o conhecimento se constrói a partir de um conceito mais abrangente, sendo, nesse caso, o conceito de transformação ${ }^{19}$, para o desenvolvimento de conceitos mais específicos, como os conceitos de transformações dos materiais, substância e mistura ${ }^{20}$, numa seqüência

\footnotetext{
${ }^{16}$ (...) aspectos relevantes da estrutura cognitiva que servem de ancoradouro para a nova informação são os chamados 'subsunçores' "(MOREIRA, 1990, p. 68).

17 "Na aprendizagem significativa há uma interação entre o novo conhecimento e o já existente na qual ambos se modificam. À medida que o conhecimento prévio serve de base para a atribuição de significados à nova informação ele também se modifica, i.e., os subsunçores vão adquirindo novos significados, se tornando mais diferenciados, mais estáveis." (MOREIRA, 1990, p. 68).

18 "(...) existência de conhecimento na estrutura cognitiva que possibilite a sua conexão com o novo conhecimento (...)" (TAVARES, 2004, p. 56)

19 "O reconhecimento de uma transformação pode ser feito através da comparação de algumas características do (s) material (is) antes e após a ocorrência da transformação que ocorre numa porção delimitada do sistema em estudo. A descrição do sistema antes da transformação define o estado inicial do sistema enquanto a descrição feita após a transformação define o estado final do sistema. Portanto, a comparação entre o estado inicial e final de um sistema fornece indicações que nos permitem reconhecer a ocorrência de transformações neste sistema." (PROQUIM, p. 5)

20 "As substâncias podem ser identificadas por suas propriedades características. A cor e o cheiro são propriedades que podem indicar qual é a substância em questão, porém não são suficientes para identificá-la ou distingui-la de uma mistura. Por outro lado, a determinação do ponto de ebulição de um material permite distinguir substância e mistura e possibilita a identificação de determinada substância. Além do ponto de ebulição, outras propriedades, como ponto de fusão, densidade e solubilidade, são utilizadas na identificação das substâncias por serem propriedades características,
} 
adequada de organização e apresentação dos conteúdos. PONTES NETO (2006, p. 119), ao escrever sobre a Teoria da Aprendizagem Significativa, relata que “(...) o material a ser aprendido dever ser suficientemente não arbitrário, isto é, deve possuir significação lógica para poder ser relacionado a idéias que estão dentro do domínio da capacidade humana de aprendizagem (...)."

“(...) Quando os subsunçores presentes na estrutura cognitiva de cada indivíduo são identificados pelo professor, inicia-se a instrução propriamente dita. O ponto de partida é a hierarquia conceitual, onde o assunto deverá ser trabalhado dos conceitos mais inclusivos e gerais, para os menos inclusivos (...)" (SANTANA \& TEIXEIRA, 2005, p. 64).

O conceito de transformação está presente como conceito mais inclusivo (AUSUBEL, 1982) e age como subsunçor para a ancoragem de novos conceitos (menos inclusivos), como substância e mistura. Portanto, quando o aluno aprende significativamente, a partir de sua interação com o grupo do qual faz parte, ele se utiliza dos atributos do conceito subsunçor para que o novo conhecimento adquira novos significados, “(...) se tornando cada vez mais elaborado, mais diferenciado, mais capaz de servir de ponte para atribuição de significados a novos conceitos (...)" (MOREIRA, 1990, p. 69).

Conseqüentemente, a resolução dos problemas propostos no material instrucional é facilitada pelas relações de similaridades e diferenças que os alunos são capazes de fazer entre idéias e conceitos, reorganizando progressivamente sua estrutura cognitiva pela diferenciação do conceito subsunçor (MOREIRA, 1990).

Conforme KASTRUP (2000) e PELIZZARI et al. (2002), o desenvolvimento cognitivo se estabelece a partir de um tempo cronológico de construção e transformação da estrutura cognitiva que "(...) é compreendida, fundamentalmente, como uma rede de conceitos organizados de modo hierárquico de acordo com o grau de abstração e de generalização (...)" (PELIZZARI et al., 2002, p. 38). Assim, desenvolver-se significa superar deficiências de conhecimento a partir de uma maneira própria de perceber, conhecer e sentir. Cada aluno irá progredir para construção do próprio conhecimento, a partir da valorização de idéias previamente estabelecidas em sua estrutura mental, permitindo-se descobrir e redescobrir outros conhecimentos, respeitando-se o tempo de cada um na percepção dos atributos dos problemas que se fizerem presentes.

Aprender, então, corresponde a um aprendizado que parte de uma idéia mais inclusiva que facilita a assimilação de informações menos inclusivas para construção de 
conhecimentos mais específicos com o qual o aprendente pode se confrontar (PONTES NETO, 2006; SANTANA \& TEIXEIRA, 2005).

Desse modo, no estudo das transformações dos materiais, um aluno que observa evidências durante um processo experimental e as relaciona a uma observação no âmbito macroscópico, enfatizando que as mesmas não são suficientes para afirmar que tenha ocorrido uma mudança no material (âmbito microscópico), está articulando aspectos observáveis (fenomenológico) dos materiais aos não observáveis. Portanto, os alunos são capazes de articular suas idéias com as do grupo ao qual pertencem, fazendo generalizações e encadeamentos de idéias mais gerais até atingir outras mais particulares (PONTES NETO, 2006; SANTANA \& TEIXEIRA, 2005; TAVARES, 2004). Este processo sob o qual o PROQUIM está estruturado é chamado, por AUSUBEL (1982), de reconciliação integrativa.

\subsection{Descrição do Material Instrucional}

Nas escolas, tem sido comum a observação de um Ensino de Ciências contrário às propostas construtivistas de construção do conhecimento, onde os professores se atêm à simples transmissão dos conteúdos científicos, por considerarem a Ciência como um corpo de conhecimentos prontos e acabados que os alunos apenas recebem de forma passiva, reproduzindo-os literal e arbitrariamente em avaliações (SCHNETZLER, 1992).

Nesse modelo de escola tradicionalista, não se considera que o aluno aprende por processos particulares, idiossincráticos, de construção do conhecimento, em que ele próprio atribui significados à nova aprendizagem ao relacioná-la às concepções já presentes em sua estrutura cognitiva. Assim, cabe ao professor descobrir inicialmente quais são os conhecimentos prévios dos alunos e relacioná-los ao material instrucional que será utilizado para estudo dos conteúdos programáticos.

O material escolhido para estudo nesta pesquisa foi desenvolvido de forma a estimular o processo investigativo (BELTRAN, 1987), em alunos e professores que o utilizarem. O emprego do PROQUIM, como material didático, auxilia na construção de conceitos químicos, possibilitando o desenvolvimento de habilidades investigativas, “(...) não para comprovar conteúdos anteriormente ensinados, mas sim solicitar que os alunos elaborem ou formulem conhecimentos a partir da observação, organização e interpretação de dados experimentais (...)" (MAZON, 1989, p. 6). Para tanto, o aluno é motivado a uma aprendizagem 
por métodos exploratórios para formulação de seus próprios julgamentos e hipóteses, partindo de uma dimensão macroscópica dos sistemas.

MAZON (1989, p. 8), em sua Dissertação de Mestrado descreve, conforme palavras expressas por SCHNETZLER ${ }^{21}$, os objetivos educacionais pretendidos pelo PROQUIM, sendo eles:

“(...) propiciar a ocorrência de aprendizagem significativa de tal forma que os alunos apliquem o conteúdo químico adquirido na resolução de problemas (...)";

“(...) propiciar o desenvolvimento de habilidades de investigação nos alunos através da realização de experiências, para coleta, organização e análise de dados experimentais, com vistas à elaboração de generalizações, isto é, conceitos, princípios e leis (...)."

Para organização do conteúdo programático desse material instrucional, seus autores propuseram um tema central, Reações Químicas (BELTRAN, 1987), em torno do qual sua abordagem metodológica facilitaria o ensino experimental associado à aprendizagem por descoberta dirigida, em que o aluno participa ativamente da construção do próprio conhecimento e o professor atua como mediador do processo de ensino-aprendizagem.

Nessa relação o material instrucional se apresenta como potencialmente significativo (AUSUBEL, 2000) a partir do instante em que o aluno se utiliza de conhecimentos adquiridos em outros momentos e os ressignifica através de atributos ancorados aos novos conceitos. É nessa interação do material instrucional com as novas aprendizagens a serem construídas pelos educandos que se insere a mediação exercida pelo professor, o qual deve provocar entre os educandos a ocorrência de conflitos cognitivos que lhes permitiram a troca de experiências no ambiente socializador da sala de aula (VIGOTSKI, 2005).

Em estudo semelhante MORAIS \& MATHEUS-VALLE (2009, p. 2) utilizaram as mesmas abordagens metodológicas. Empregaram um material considerado potencialmente significativo com alunos de primeiro ano de Ensino Médio para estudar Conceitos de Mecânica. Para tanto, inicialmente verificaram quais eram as concepções prévias dos educandos e, posteriormente, abordaram as aulas sobre o tema. Já “(..) a escolha pela teoria de Vygotsky se deu especialmente porque ela se fundamenta na idéia de que a aprendizagem ocorre principalmente pela interação social dos alunos entre si e desses com o professor no contexto em que estão inseridos, levando a interiorizar os significados".

Esse estudo foi realizado com cinqüenta e seis alunos de primeiro ano de Ensino Médio de uma escola pública da cidade de Viçosa em Minas Gerais, no ano de 2007. Dos

\footnotetext{
${ }^{21}$ Roseli Pacheco Schnetzler foi orientadora da Dissertação de Mestrado de Antonieta Bianchi Mazon e uma das autoras do PROQUIM.
} 
resultados obtidos com sua pesquisa, esses autores observaram que a maioria dos educandos utilizam-se de concepções espontâneas do conceito de dinâmica, ou seja, "(...) conceitos contrários aos aceitos cientificamente (...)" (MORAIS \& MATHEUS-VALLE, 2009, p. 4).

Como na abordagem apresentada na pesquisa por MORAIS \& MATHEUS-VALLE (2009), a utilização do PROQUIM, que é um material construído a partir de abordagens ausubelianas, se justifica por suscitar a resolução de atividades tanto em momentos individualizados como coletivos, promovendo discussões coletivas em que as idéias são compartilhadas e ambos os sujeitos do processo ensino e aprendizagem (professor e aluno) interagem para construção coletiva do conhecimento.

O PROQUIM é um material potencialmente significativo por apresentar o conteúdo com um significado lógico para os educandos e estar, ao mesmo tempo, relacionado ao cotidiano, o que acaba por acarretar uma predisposição ao aprendizado de conceitos científicos.

O aluno atua, nesse sentido, como principal sujeito na construção do conhecimento e o professor como facilitador desse processo, promovendo a interação do aluno com o material instrucional e o objeto sob estudo. Portanto, compete ao professor identificar quais são os conhecimentos prévios dos alunos, pois estes já vêm para a escola com idéias sobre fenômenos e conceitos científicos pré-estabelecidos e que, muitas vezes, podem acabar por comprometer a aprendizagem em sala de aula.

Isso se deve ao fato de, muitas vezes, o conhecimento já estabelecido na estrutura cognitiva do educando ser resistente a mudanças afetando sua participação ativa no processo, gerando dificuldades na aprendizagem de novos conceitos e ditando como será o percurso da aula (BELLO, 2004; SCHNETZLER, 1992).

A Figura 3.1 apresenta os conceitos introduzidos pelo PROQUIM, nos capítulos 1 e $2^{22}$. Ao conceito subsunçor transformação, mais abrangente, são ancorados diversos atributos até que se atinjam conceitos menos inclusivos, como os conceitos de substância e mistura.

\footnotetext{
${ }^{22}$ Os capítulos 1 e 2 do material instrucional utilizado nesta Dissertação como fonte para coletas de dados constam dos anexos B1 e B2, nas páginas 164 e 177, respectivamente.
} 


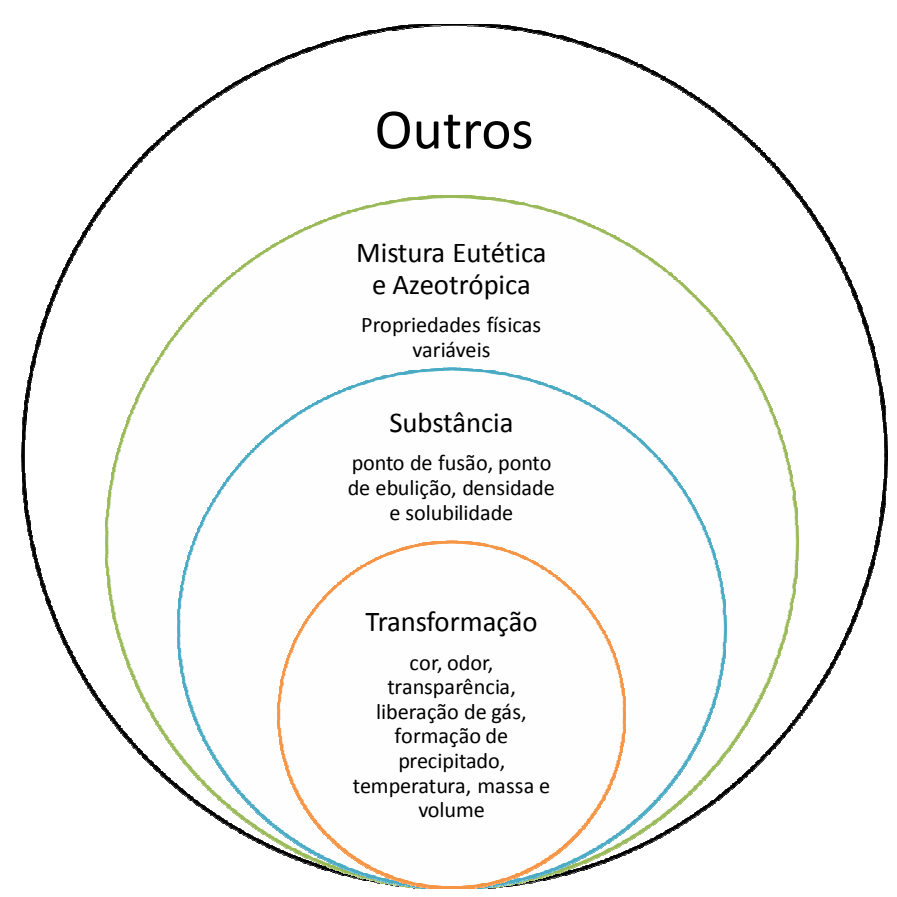

Figura 3.1. Apresentação dos conceitos introduzidos, inicialmente, pelo PROQUIM

Com a finalidade de contrapor o ensino tradicionalista e visando a aprendizagem significativa de conceitos químicos, por considerar o aluno um ser investigativo e em constante processo de renovação de sua estrutura cognitiva, é que utilizamos o PROQUIM. Nossa hipótese era a de que assim os aprendizes seriam motivados à aprendizagem científica pela utilização de um material que facilita o trabalho do professor, por introduzir os conteúdos hierarquicamente, sempre promovendo a articulação das ações do professor às concepções prévias dos alunos.

Assim, no primeiro capítulo do PROQUIM estuda-se "O que é uma reação química", ou seja, as formas como cada material pode sofrer diversas transformações, relacionandoas a algo perceptível ao âmbito macroscópico, como cor, odor, transparência, liberação de gás, formação de precipitado.

Os alunos são conduzidos a dois momentos distintos. Inicialmente, à construção de Tabelas Individuais, relacionando transformações que ocorrem em seu cotidiano, bem como suas formas de reconhecimento. Esse primeiro momento incide sobre a exploração das concepções prévias dos alunos, a respeito do conceito de transformação, ou seja, para a evocação do conceito subsunçor existente na estrutura cognitiva dos educandos.

As fases de estudos do capítulo 1 sucederam-se como apresentado na Tabela 3.1: 
Tabela 3.1- Fases de estudo do capítulo 1 do PROQUIM ${ }^{23}$

\begin{tabular}{|c|c|c|c|}
\hline Etapa & Atividade & Desenvolvimento & Objetivos \\
\hline Texto l-1 & $\begin{array}{l}\text { A Química é } \\
\text { velha? }\end{array}$ & Leitura de texto. & $\begin{array}{l}\text { Sensibilização dos alunos quanto a mudanças ocorridas em } \\
\text { tempos remotos e atuais }\end{array}$ \\
\hline \multirow{2}{*}{$\begin{array}{l}\text { Atividade l- } \\
1\end{array}$} & \multirow{2}{*}{$\begin{array}{l}\text { Observando } \\
\text { transformações }\end{array}$} & $\begin{array}{l}\text { Construção de tabelas } \\
\text { individuais }\end{array}$ & Listar transformações ocorridas no dia-a-dia \\
\hline & & Construção de tabelas coletivas & $\begin{array}{l}\text { Elencar os diversos tipos de transformações que ocorrem no dia- } \\
\text { a-dia e suas formas de reconhecimento }\end{array}$ \\
\hline Texto I-2 & $\begin{array}{l}\text { Reconhecendo } \\
\text { transformações }\end{array}$ & Leitura de texto & $\begin{array}{l}\text { Reconhecer um sistema e suas características antes e após sua } \\
\text { transformação }\end{array}$ \\
\hline \multirow{8}{*}{$\begin{array}{l}\text { Guia } \\
\text { Experimen- } \\
\text { tal l-1 }\end{array}$} & \multirow{8}{*}{$\begin{array}{l}\text { O que é uma } \\
\text { reação } \\
\text { química? }\end{array}$} & Introdução & $\begin{array}{l}\text { Apresentar aos alunos o que deverão observar durante } 0 \\
\text { procedimento experimental }\end{array}$ \\
\hline & & Material Necessário & $\begin{array}{l}\text { Informar aos alunos quais materiais serão necessários à } \\
\text { execução do procedimento experimental }\end{array}$ \\
\hline & & Procedimento & $\begin{array}{l}\text { Investigar as características do sistema em estudo antes e após a } \\
\text { transformação }\end{array}$ \\
\hline & & Tabela de dados & Sistematizar os dados observados \\
\hline & & Análise de dados & Diferenciar os aspectos macroscópicos das transformações \\
\hline & & Conclusões & $\begin{array}{l}\text { Aplicar os conhecimentos construídos em novas situações de } \\
\text { aprendizagem }\end{array}$ \\
\hline & & Exercícios & $\begin{array}{l}\text { Avaliar os conhecimentos desenvolvidos em novas situações de } \\
\text { aprendizagem }\end{array}$ \\
\hline & & Questões para discussão & Sintetizar com os alunos as situações observadas \\
\hline Texto I-3 & Síntese & Leitura de texto & $\begin{array}{l}\text { Concluir sobre aspectos observáveis no âmbito macroscópico e } \\
\text { inferir que também é necessária a observação microscópica dos } \\
\text { sistemas em estudo }\end{array}$ \\
\hline
\end{tabular}

Num segundo momento, as Tabelas são construídas coletivamente, após discussões mediadas pela professora, para que se esgotem todos os argumentos relacionados ao fato de ser uma transformação um processo dinâmico e não apenas um momento estanque. Assim, os alunos têm a oportunidade de expor suas idéias e também de relacioná-las às dos outros alunos participantes do grupo ao qual pertencem, ancorando, desta forma, novos atributos aos conceitos já presentes em sua estrutura cognitiva.

Desse modo, tanto o material utilizado como o professor, agem sobre o educando trazendo até ele experimentos que possibilitem construir conceitos de maneira individual e também coletiva. Simultaneamente, o educando também age sobre o material e sobre o professor trazendo suas experiências cotidianas, seu conhecimento e sua vivência que, em interação e inter-relação com o PROQUIM, possibilitam a construção do conhecimento.

Nessa apreciação, o aluno que aprendeu de forma significativa deve ser capaz de identificar qual é o sistema que está sendo analisado, bem como o estado inicial e final da transformação do material, percebendo as características antes e após o processo de mudança, capacitando-o a observar, distinguir e analisar as diferenças ocorridas no sistema em estudo. O material, que a priori parece desconhecido ao educando, torna-se familiar, permitindo que o aluno construa algo diferente de sua idéia prévia e também diferente do material, mas contendo ambos.

${ }^{23}$ Cf. nota 22 deste capítulo. 
A partir desse momento, o aluno é levado a trabalhar de forma cooperativa, pois grande parte das atividades é desenvolvida em grupo, como, por exemplo, o "Guia Experimental", etapa subseqüente à construção das tabelas, fazendo-se experimentos que demonstram a ocorrência de uma transformação e introduzindo a linguagem científica para um direcionamento do olhar do aluno sobre o processo.

Após os ensaios propostos, os alunos fazem uma análise dos dados coletados (momentos de atividades individualizadas), com o objetivo de adaptação aos novos conceitos que se apresentam para posterior aplicação nas situações-problema indicadas nas atividades intituladas "Conclusões" e "Exercícios", onde poderão desenvolver e aplicar os conhecimentos adquiridos anteriormente, através de seus conhecimentos prévios, relacionando-os à solução do problema atual.

Nas "Questões para Discussão", os alunos socializam suas idéias, com mediação da professora, de modo que todos têm oportunidade de refletir sobre o que fizeram até aquele momento e o quê os levou a chegar a determinadas constatações.

BELLO (2004, p. 210), em suas pesquisas, fala que “(..) as idéias prévias dos educandos surgem para formularem respostas a sua necessidade de interpretar os fenômenos naturais e conceitos científicos (...)", ou seja, é através de suas concepções prévias que os novos conhecimentos irão adquirir significados, pois o aluno estará apto a ressignificar o que já sabe através da retenção de novos atributos aos conceitos já estabelecidos em sua estrutura mental.

Para finalizar o capítulo I do PROQUIM, faz-se a leitura do texto "Síntese", que apresenta os conceitos abordados, evidenciando aspectos do âmbito macroscópico e problematizando sua abrangência como critério para decidir se determinados materiais sofreram ou não alterações em suas propriedades. Apenas a observação de evidências, não se é capaz de determinar alterações nas propriedades específicas dos materiais, então, para essa conclusão, é importante se realizar uma análise mais detalhada do sistema. Alterações nas propriedades específicas devem indicar se houve ou não formação de novos materiais, mas, em muitos casos, não se consegue decidir se houve ou não formação de um novo material. Conseqüentemente, é imprescindível o estudo de propriedades específicas dos materiais, como o ponto de ebulição e fusão, densidade e solubilidade, que definem se os sistemas sob estudo são substâncias puras ou misturas.

No Capítulo 2, o estudo do Ponto de Ebulição se dá pela observação de uma das propriedades mais indicadas para identificar substâncias líqüidas em um sistema, verificando seu Ponto de Ebulição, por aquecimento do líquido ou resfriamento do vapor 
(Ponto de Liquefação), até atingir temperatura constante. Para identificação de sólidos, o ideal é a determinação do Ponto de Fusão de sólidos ou por solidificação de líquidos (Ponto de Solidificação), até que a temperatura permaneça constante.

Também nesse capítulo estuda-se a identificação da densidade de alguns materiais, para os alunos poderem observar que as substâncias possuem densidades diferentes que também são específicas para cada uma. No caso das misturas que apresentam aspecto homogêneo (soluções), a identificação das substâncias presentes se torna ainda mais difícil, sendo preciso estabelecer processos de separação dos materiais para posterior identificação, através de constantes físicas, pois para misturas essas propriedades são variáveis, porque dependem de sua composição. As fases de estudo desse segundo capítulo sucederam-se como apresentado na Tabela 3.2:

Tabela 3.2 - Fases de estudo do capítulo 2 do PROQUIM ${ }^{24}$

\begin{tabular}{|c|c|c|c|}
\hline Etapa & $\begin{array}{l}\text { Propriedades } \\
\text { específicas }\end{array}$ & Desenvolvimento & Objetivos \\
\hline \multirow{8}{*}{ 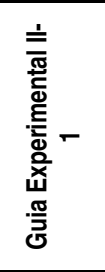 } & \multirow{8}{*}{ Ponto de ebulição } & Introdução & \multirow{8}{*}{$\begin{array}{l}\text { O estudo do ponto de ebulição tem por objetivo estudar uma } \\
\text { das propriedades específicas dos materiais, em sua passagem } \\
\text { do estado físico líquido para o gasoso, distinguindo líquidos } \\
\text { puros de soluções, por meio de aquecimento ou resfriamento, } \\
\text { até atingir temperatura constante, que é própria para cada } \\
\text { material. }\end{array}$} \\
\hline & & Material necessário & \\
\hline & & Procedimento & \\
\hline & & Tabela de dados & \\
\hline & & Análise de dados & \\
\hline & & Conclusões & \\
\hline & & Exercícios & \\
\hline & & Questões para discussão & \\
\hline \multirow{8}{*}{ 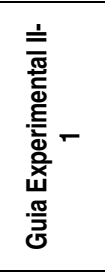 } & \multirow{8}{*}{ Ponto de fusão } & Introdução & \multirow{8}{*}{$\begin{array}{l}\text { O estudo do ponto de fusão tem por objetivo estudar uma das } \\
\text { propriedades específicas dos materiais, em sua passagem do } \\
\text { estado físico sólido para o líquido, identificando sólidos puros de } \\
\text { misturas, por meio de aquecimento ou resfriamento, até atingir } \\
\text { temperatura constante, que é própria para cada material. }\end{array}$} \\
\hline & & Material necessário & \\
\hline & & Procedimento & \\
\hline & & Tabela de dados & \\
\hline & & Análise de dados & \\
\hline & & Conclusões & \\
\hline & & Exercícios & \\
\hline & & Questões para discussão & \\
\hline \multirow{5}{*}{ 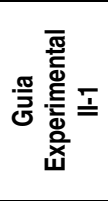 } & \multirow{5}{*}{ Densidade } & Introdução & \multirow{5}{*}{$\begin{array}{l}\text { O estudo da densidade dos materiais tem por objetivo estudar a } \\
\text { composição dos materiais que compõem uma mistura, } \\
\text { caracterizando as substâncias por diferenciá-las das misturas. }\end{array}$} \\
\hline & & Material necessário & \\
\hline & & $\begin{array}{l}\text { Procedimento, Análise de dados e } \\
\text { Conclusões Parte A e Parte B }\end{array}$ & \\
\hline & & Exercícios & \\
\hline & & Questões para discussão & \\
\hline \multirow{7}{*}{ 竞 } & \multirow{7}{*}{ Solubilidade } & Introdução & \multirow{7}{*}{$\begin{array}{l}\text { O estudo da solubilidade dos materiais tem por objetivo estudar } \\
\text { a dissolução de sólidos, de uma mistura, em água e outros } \\
\text { solventes, a fim de reconhecer esta substância por sua } \\
\text { propriedade específica. }\end{array}$} \\
\hline & & Material necessário & \\
\hline & & Procedimento Parte A e Parte B & \\
\hline & & Análise de dados & \\
\hline & & Conclusões & \\
\hline & & Exercícios & \\
\hline & & Questões para discussão & \\
\hline
\end{tabular}

Após os procedimentos experimentais para identificação das propriedades específicas dos materiais, os alunos analisam e comparam os dados obtidos e constroem gráficos que representam o comportamento dos materiais sob aquecimento, indicando os pontos que corresponderiam à ebulição ou fusão dos materiais. Posteriormente a essa análise, os alunos são apresentados a outra série de exercícios que lhes permitem aplicar os conhecimentos observados durante a realização dos experimentos com outras situações de

${ }^{24}$ Cf nota 22 deste capítulo. 
aprendizagem, para que possam construir conceitos mais específicos como de substância e mistura. Para finalizar essa atividade, os alunos discutem situações cotidianas, apresentadas de forma a mobilizar os conhecimentos construídos até o momento.

Nesse estudo os alunos poderão verificar algumas evidências da existência ou não de um ou mais materiais em um sistema, considerando a observação das propriedades específicas dos materiais e, assim, ressignificar os novos conceitos, sempre ancorando novos atributos ao conceito subsunçor já presente na estrutura cognitiva. Essa metodologia de ensino se identifica com a atual Proposta Curricular para o ensino de Química, implementada nas escolas públicas estaduais pelo governo de São Paulo (SÃO PAULO, 2008), sendo que uma dessas escolas foi o cenário para o estudo das atividades analisadas nesta pesquisa.

\subsection{O PROQUIM e a Proposta Curricular para o ensino de Química no Estado de São Paulo em 2008}

Visando a melhoria do ensino de Química no Brasil e a inserção dos cidadãos no mundo globalizado, tem-se instaurado no país diversas medidas de reforma na educação, como o aumento do número de vagas nas escolas, sistemas centralizados de avaliação e programas de formação continuada de docentes (ANDRADE et al., 2004 ${ }^{25}$; LOPES, 2002). Porém, a realidade que se observa nas escolas públicas brasileiras, em relação ao aprendizado de Química fragmentado e sem qualquer significação cultural (BRASIL ${ }^{26}, 1999$; SCHNETZLER, 2002), leva-nos a acreditar que tais medidas não têm surtido efeito significativo na formação dos educandos.

Atualmente, as tendências construtivistas presentes no PROQUIM e implícitas nos documentos oficiais que regem a organização dos conteúdos curriculares, envolvem o processo de ensino-aprendizagem na solução de problemas e em atividades investigativas que estimulam os alunos ao estudo das Ciências, elucidando suas concepções prévias sobre fenômenos e promovendo o desenvolvimento do raciocínio (KRASILCHIK, 2000).

Para tanto, observa-se, no material didático PROQUIM, relação com a Proposta Curricular do Estado de São Paulo para o ensino de Química (SÃO PAULO, 2008). Esse

\footnotetext{
${ }^{25}$ Centro de Gestão e Estudos Estratégicos - Ciência, Tecnologia e Inovação

${ }^{26}$ MINISTÉRIO DA EDUCAÇÃO. Parâmetros Curriculares Nacionais: ensino médio. Brasília: Ministério da Educação, 1999.
} 
material, apesar de ter sido desenvolvido na década de 1980, ainda sob a Lei de Diretrizes e Bases 5692/71 que visava à formação profissional do educando "(...) por meio de disciplinas preparatórias para o trabalho" (KRASILCHIK, 2000, p. 87), mantém afinidade com a atual proposta, que estimula os alunos a processos investigativos para construção do próprio conhecimento, pois, como afirmam COLL \& SOLÉ (2002, p. 22) “(...) essa construção pessoal deve ser orientada no sentido de aproximar-se do culturalmente estabelecido, compreendendo-o e podendo usá-lo de múltiplas e variadas formas".

Segundo a ex-secretária da Educação do Estado de São Paulo, Maria Helena Guimarães de Castro, a atual Proposta Curricular do Estado de São Paulo (SÃO PAULO, 2008, p. 5), propõe-se a “(...) organizar melhor o sistema educacional de São Paulo (...)", pois a Lei de Diretrizes e Bases 9394/96, que "dava autonomia às escolas para estabelecerem seus próprios projetos pedagógicos, apresentou-se ineficiente".

A recente Proposta Curricular (SÃO PAULO, 2008) tem em vista a melhoria da aprendizagem dos educandos, auxiliando $\mathrm{o}$ trabalho do educador $\mathrm{e}$ articulando os conteúdos programáticos ao cotidiano dos alunos, considerando seus conhecimentos acumulados.

Assim como no PROQUIM, a Proposta Curricular prioriza o progresso dos processos reflexivos nos alunos, através do desenvolvimento de competências e habilidades leitoras e escritoras. Para tanto, a Secretaria da Educação, com a cooperação de vários colaboradores, organizou o Caderno do Professor, que tem a finalidade de auxiliar o professor através da apresentação de diversas situações de aprendizagem, com sugestões e estratégias que estimulam o processo reflexivo promovido pelo exercício de atividades experimentais em grupo e trabalhos complementares.

FERREIRA \& DIAS (2002) e OLIVEIRA \& SANTOS (2005) comentam que a competência leitora é uma exigência da sociedade e o uso dessa habilidade insere os indivíduos no contexto cultural da sociedade, por meio de uma escola que estimula seus alunos a serem cidadãos críticos e reflexivos. Ler, então, é uma atividade que faz parte do cotidiano do ser humano, porém a simples leitura não confere significado culturalmente construído pelo educando. É necessário, portanto, que ao interagir com o material instrucional, PROQUIM, os alunos leiam e compreendam o significado das mensagens expressas em suas atividades; é através da aquisição do conhecimento construído pela interação entre o cotidiano, o material instrucional contextualizado, o professor compromissado e o grupo de alunos ao qual pertencem que eles se sentirão como sujeitos que aprendem e podem interferir significativamente no meio no qual estão incluídos. 
Nesse contexto, a ação dos professores merece grande destaque, devendo atuar não apenas como transmissores de conhecimentos e sim como facilitadores do processo de aprendizagem, por meio da contextualização dos conteúdos curriculares. O professor precisa ser um leitor apto às mudanças para poder influenciar o comportamento de seus alunos, no que se refere aos hábitos de leitura. OLIVEIRA \& SANTOS (2005, p. 119), em artigo escrito sobre a compreensão da leitura, afirmam que “(...) sendo um leitor hábil e apresentando excelência nos vários níveis e tipos de leitura, o docente-leitor poderá influenciar positivamente o comportamento do aluno-leitor (...)."

Indivíduos que desenvolvem habilidades de leitura e escrita são capazes de interferir na sociedade. Assim, quando os alunos aprendem a ler e escrever tem a possibilidade de seguir por diversos caminhos, ou seja, "(...) ao ler, o indivíduo constrói os seus próprios significados, elabora suas próprias questões e rejeita, confirma e/ou reelabora as suas próprias respostas. É ele quem inscreve ou reinscreve o significado do escrito a partir de sua própria história (...)" (FERREIRA \& DIAS, 2002, p. 40).

Tanto o PROQUIM (1986) como a Proposta Curricular para o Ensino de Química no Estado de São Paulo (SÃO PAULO, 2008) priorizam o desenvolvimento pessoal do educando, aspecto importante, pois a "(...) educação precisa estar a serviço desse desenvolvimento, que coincide com a construção da identidade, da autonomia e da liberdade (...)" (SÃo PAULO, 2008, p. 11).

“(...) O desenvolvimento pessoal é um processo de aprimoramento das capacidades de agir, pensar, atuar sobre o mundo e lidar com a influência do mundo sobre cada um, bem como atribuir significados e ser percebido e significado pelos outros, apreenderem a diversidade e ser compreendido por ela, situar-se e pertencer (...)". (SÃO PAULO, 2008, p. 11)

Essa idéia estava presente na reformulação da Proposta Curricular para o Ensino de Química - 2º grau (1986), a qual já apresentava o conteúdo de forma contextualizada à realidade do aluno (GANDOLFI \& ROSSI, 2008). Essa mesma preocupação encontra-se na organização dos conteúdos presentes no PROQUIM, o qual tem por objetivo o desenvolvimento do educando através de uma aprendizagem contextualizada ao seu cotidiano.

A Proposta Curricular (SÃO PAULO, 2008) articula o ensino da Química a aspectos relevantes de serem estudados para que os alunos possam estabelecer conexões entre seus conhecimentos e o mundo do qual fazem parte. Portanto, a Proposta Curricular para o ensino de Química (SÃO PAULO, 2008) alicerça o estudo dessa Ciência a partir da transformação dos materiais, suas propriedades e modelos explicativos. Assim, estudam-se, primeiramente, os aspectos macroscópicos dos materiais, contrariamente ao que ocorria na 
aprendizagem memorística de fórmulas e símbolos, que partia de explicações microscópicas do estudo de modelos atômicos e suas estruturas.

ROSA \& SCHNETZLER (1998) afirmam que o estudo do conceito de transformações químicas permite que os alunos exponham suas concepções a respeito do conceito, muitas vezes distantes do conhecimento científico, isso se dá porque o aluno carrega concepções de seu cotidiano para o ambiente escolar, onde a linguagem científica começa a ser estabelecida em sua estrutura cognitiva.

Então, a fim de comparar a atualização do PROQUIM, com a organização e seleção de conteúdos apresentados no Caderno do Professor - Proposta Curricular (SÃO PAULO, 2008), criamos a Tabela 3.3, que apresenta os conteúdos curriculares para o processo de ensino-aprendizagem de Química na $1^{\underline{a}}$ série do Ensino Médio, período que foi o foco de estudo para esta pesquisa. Ambos os materiais procuram valorizar as experiências prévias dos educandos, trazendo seus saberes para sala de aula, a fim de que possam ser vinculados ao conhecimento apresentado nas escolas.

Pode-se observar que as duas Propostas de ensino têm como eixo norteador dos conteúdos curriculares de Química, Reações Químicas, através do tema transformação dos materiais para o estudo dos alunos da 1ㄹ série do Ensino Médio. Em ambas as propostas percebe-se que há uma preocupação de cunho social, pois nota-se existência de textos contextualizados envolvendo os temas geradores em situações de aprendizagem, cujo objetivo fundamental é inserir o cidadão no mundo globalizado, formando-o para a vida (LOPES, 2002).

Os conteúdos escolares são, geralmente, influenciados pelo contexto social e conduzem ao desenvolvimento de determinadas habilidades, de acordo com o que se considera mais adequado à faixa etária daqueles educandos (CASTRO, 2001).

"Os conteúdos escolares constituem um reflexo e uma seleção (cujos critérios sempre são discutíveis e revisáveis) daqueles aspectos da cultura cuja aprendizagem considera-se que contribuirá para o desenvolvimento dos alunos em sua dupla dimensão de socialização - na medida em que os aproximam da cultura do seu meio social - e de individualização, na medida em que o aluno construirá com esses aspectos uma interpretação pessoal, única, na qual sua contribuição é decisiva (COLL \& SOLÉ, 2002, p. 22)". 
Tabela 3.3 - Organização de conceitos introduzidos pelo PROQUIM (1986) e pelo Caderno do Professor - Proposta Curricular (SÃO PAULO, 2008)

\begin{tabular}{|c|c|c|c|}
\hline \multicolumn{4}{|c|}{ Diferentes Propostas Curriculares para o ensino de Química } \\
\hline & PROQUIM (1986) & \multicolumn{2}{|c|}{$\begin{array}{l}\text { Caderno do Professor - Proposta Curricular (SÃO } \\
\text { PAULO, 2008) }\end{array}$} \\
\hline$\frac{\circ}{8}$ & Conteúdo & 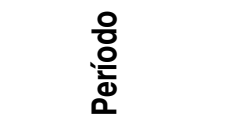 & Conteúdo \\
\hline \multirow{2}{*}{ 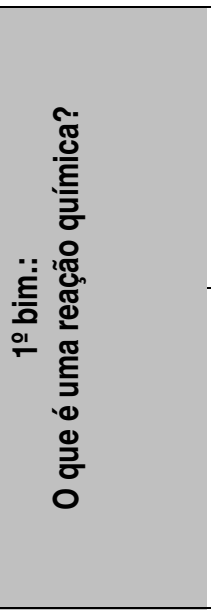 } & $\begin{array}{l}\text { Transformações químicas no dia-a- } \\
\text { dia: } \\
\text { a) observação; } \\
\text { b) reconhecimento; } \\
\text { c) comparação; } \\
\text { d) evidências; } \\
\text { e) sistemas: estados inicial e final }\end{array}$ & \multirow{2}{*}{ 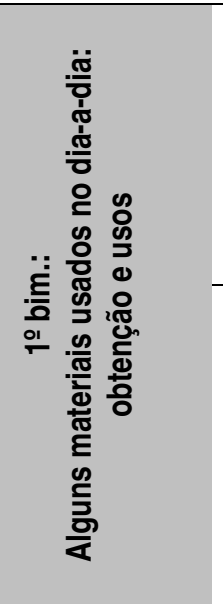 } & $\begin{array}{l}\text { Transformações químicas no dia-a-dia: } \\
\text { a) evidências; } \\
\text { b) tempo envolvido; } \\
\text { c) energia envolvida; } \\
\text { d) reversibilidade. }\end{array}$ \\
\hline & $\begin{array}{l}\text { Propriedades dos materiais: } \\
\text { a) calor; } \\
\text { b) massa; } \\
\text { c) volume; } \\
\text { d) dissolução; } \\
\text { e) estados físicos. }\end{array}$ & & $\begin{array}{l}\text { Reagentes, produtos e suas } \\
\text { propriedades: } \\
\text { a) caracterização de substâncias que } \\
\text { constituem os reagentes e produtos } \\
\text { das transformações em termos de suas } \\
\text { propriedades; } \\
\text { b) separação e identificação das } \\
\text { substâncias. }\end{array}$ \\
\hline 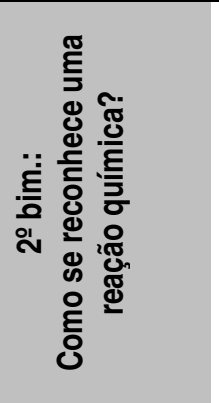 & $\begin{array}{l}\text { Estudo das propriedades dos } \\
\text { materiais: } \\
\text { a) ponto de ebulição; } \\
\text { b) ponto de fusão; } \\
\text { c) densidade; } \\
\text { d) solubilidade. }\end{array}$ & 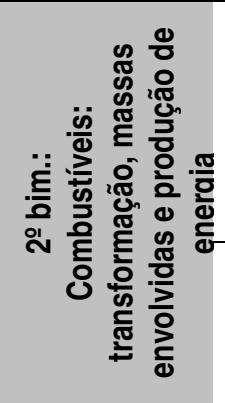 & $\begin{array}{l}\text { Reagentes, produtos e suas relações } \\
\text { em massa e calor: } \\
\text { a) reações de combustão; } \\
\text { b) aspectos quantitativos nas } \\
\text { transformações químicas; } \\
\text { c) poder calorífico dos combustíveis. } \\
\text { Primeiras idéias ou modelos sobre a } \\
\text { constituição da matéria: } \\
\text { a) modelo de Dalton sobre a } \\
\text { constituição da matéria. }\end{array}$ \\
\hline 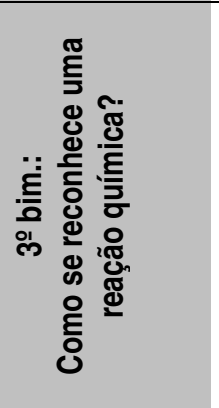 & $\begin{array}{l}\text { Fatos e explicações: } \\
\text { a) mudanças de estado físico; } \\
\text { b) uso de modelos: representação } \\
\text { macroscópica do que ocorre a nível } \\
\text { microscópico Processos de } \\
\text { separação das misturas: } \\
\text { a) decantação; } \\
\text { b) filtração; } \\
\text { c) destilação. }\end{array}$ & 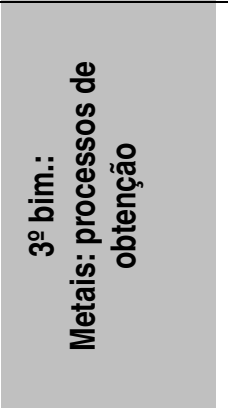 & $\begin{array}{l}\text { Representação de transformações } \\
\text { químicas: } \\
\text { a) processos de obtenção do ferro e do } \\
\text { cobre; } \\
\text { b) linguagem simbólica da Química; } \\
\text { c) Tabela Periódica; } \\
\text { d) balanceamento e interpretação das } \\
\text { transformações químicas; } \\
\text { e) equação química: relações entre } \\
\text { massa, número de partículas e energia. }\end{array}$ \\
\hline 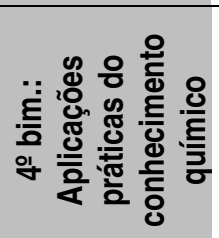 & $\begin{array}{l}\text { Representação macroscópica do } \\
\text { nível microscópico da matéria: o uso } \\
\text { de modelos. }\end{array}$ & 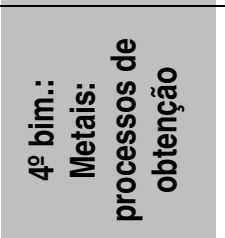 & $\begin{array}{l}\text { Relações quantitativas envolvidas na } \\
\text { transformação química: } \\
\text { a) estequiometria; } \\
\text { b) impactos ambientais na produção do } \\
\text { ferro e do cobre. }\end{array}$ \\
\hline
\end{tabular}

Assim, delimitamos no Quadro 3.1, algumas habilidades similares, entre O PROQUIM (1986) e o Caderno do Professor (SÃO PAULO, 2008), que se pretendem desenvolver para a formação de educandos da 1ª série do Ensino Médio, na disciplina de Química: 


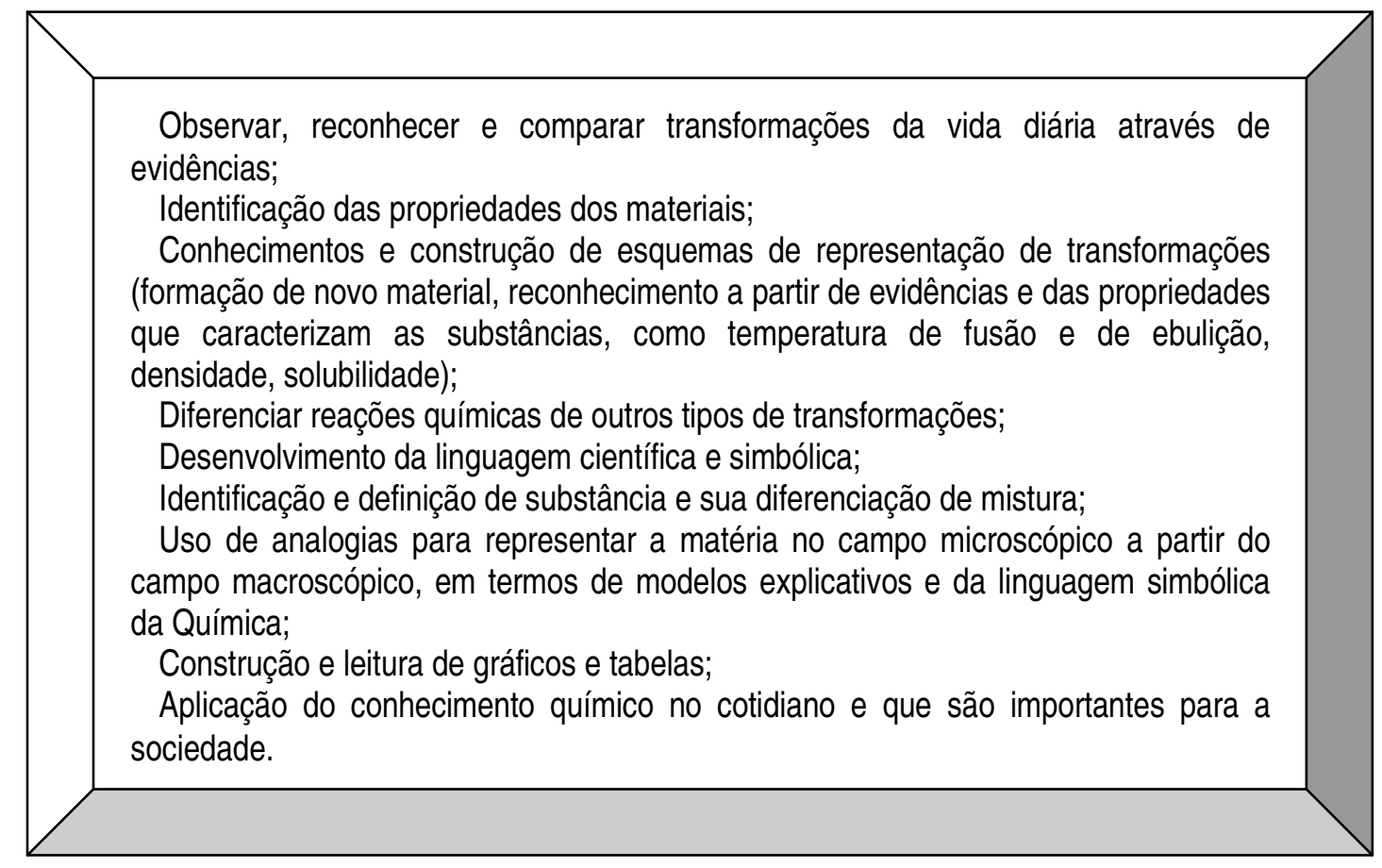

Quadro 3.1 - Habilidades a serem desenvolvidas pelos alunos através das situações de aprendizagem apresentadas pelo PROQUIM (1986) e pelo CADERNO DO PROFESSOR - Proposta Curricular (SÃO PAULO, 2008)

O desenvolvimento dessas habilidades permite que os alunos aprimorem suas estruturas cognitivas mentais superiores. Assim, poderão interferir significativamente na sociedade, pois a utilização de qualquer um desses materiais instrucionais facilita a reelaboração do conhecimento informal para o desenvolvimento do conhecimento científico pela aquisição da linguagem científica.

O PROQUIM, por ser um material que apresenta situações de aprendizagem a serem desenvolvidas individual e coletivamente, considerando os conhecimentos prévios dos alunos e sua interação com parceiros que possuem conhecimentos ou habilidades similares, explora as potencialidades para a construção do conhecimento científico por meio da ressignificação de conceitos em atividades para a construção coletiva do conhecimento.

Essa interação entre os pares chamada por Vigotski de aprendizagem colaborativa (MOLL, 1996) influencia a reorganização da estrutura cognitiva dos indivíduos pela ressignificação de conceitos e ativação da Zona de Desenvolvimento Proximal (VIGOTSKI, 1991).

O processo de aprendizagem colaborativa ativa a Zona de Desenvolvimento Proximal, durante a qual os alunos imitam gestos e falas de parceiros mais experientes, desenvolvendo suas potencialidades até que o conhecimento se torne real (significativo), ou 
seja, os domínios afetivo, cognitivo e motor estão interligados em uma unidade para o desenvolvimento intelectual do educando (sentido), onde o aprender a aprender é imprescindível para o estabelecimento e uso de uma linguagem mediada culturalmente.

Assim, como afirma OLIVEIRA (1992, p. 80), “(...) cultura é um palco de negociações onde seus membros estão em constante processo de recriação e reinterpretação de informações, conceitos e significados". Além disso, "(...) quando o indivíduo toma posse das formas de funcionamento psicológico dadas culturalmente, torna-as suas e as utiliza como instrumento pessoal de pensamento e ação no mundo." 


\section{Capítulo 4}

\section{Metodologia}

“A construção do novo é sempre insegura, exigindo ao máximo a criatividade, processo ao mesmo tempo rigoroso, prazeroso $e$ gratificante (MORAES \& GALIAZZI, 2006)" 


\subsection{Caracterização da pesquisa}

\subsubsection{Abordagem}

Esta pesquisa foi realizada na perspectiva de uma abordagem qualitativa (LAKATOS \& MARCONI, 1983) de investigação das concepções dos alunos acerca do conceito de transformação. Foram coletadas fotografias e material escrito elaborado de forma individual e em discussões coletivas sobre as atividades realizadas durante as aulas de Química desenvolvidas ao longo do ano letivo. Os dados foram obtidos destas fontes através de Análise de Conteúdo (BARDIN, 2006) ${ }^{27}$.

\subsubsection{Público-alvo}

Os grupos selecionados para esta pesquisa são alunos da 1aㅡ série do Ensino Médio, período julgado propício para o início de um trabalho que envolve processos reflexivos individuais e coletivos (LURIA, 2001; VIGOTSKI, 2005), em uma perspectiva sócio-construtivista (LABURÚ \& CARVALHO, 2005), uma vez que os alunos estão iniciando um novo ciclo de aprendizagem. VIGOTSKI (2005) afirma que é na fase da adolescência que se concretiza a formação de conceitos na estrutura cognitiva.

O público-alvo são alunos dos anos de 2006 - turmas A e B, totalizando 53 alunos e 2007 (83 alunos, distribuídos nas turmas A, B e C), de uma escola pública da rede estadual de São Paulo localizada no Bairro da Penha, na Zona Leste da cidade de São Paulo (SP), escola da qual a professora-pesquisadora é titular de cargo efetivo. As idades dos alunos variavam entre 14 e 17 anos.

\footnotetext{
27 “(...) um conjunto de técnicas de análise das comunicações visando obter, por procedimentos sistemáticos e objetivos de descrição do conteúdo das mensagens, indicadores (quantitativos ou não) que permitam a inferência de conhecimentos relativos às condições de produção/recepção (variáveis inferidas) destas mensagens" (BARDIN, 2006, p. 37).
} 


\subsubsection{O método e a caracterização do ambiente de pesquisa}

Pode-se compreender o processo de construção do conhecimento através do método dialético (LAKATOS \& MARCONI, 1983). Segundo o método dialético, em toda afirmação cabe uma negação, sendo que ambas se convertem para significar um novo conhecimento, que contem em si os atributos anteriores. Esse antagonismo presente na significação de um mesmo conceito pode levar a um conflito cognitivo conduzindo os educandos a ressignificações de conhecimentos já instituídos.

\footnotetext{
“(...) a contradição está presente em toda realidade: tudo tem relação com um todo que encerra, em si próprio, contradições. Nada é finito, mesmo que assim pareça: o quê se apresenta como finito é algo que irá se transformar, apresentando-se aos nossos olhos sob outro aspecto. Os contrários são verso e anverso de uma mesma realidade; portanto, ao mesmo tempo que se antagonizam, também se identificam. A dialética é a lógica do conflito, do movimento, da vida (LAKATOS \& MARCONI, 1983, p. 71)."
}

Durante as aulas, que se realizaram no laboratório de Química da escola (Figuras 4.1 a 4.4) com a finalidade de construir um saber socialmente compartilhado pelo grupo, adotaram-se metodologias de trabalho que não se ativessem à transmissão cultural (Figuras 4.5 e 4.6), criando uma situação favorável à implementação de um ambiente adequado ao estudo e à apropriação de conhecimentos científicos (NEHRING et al., 2002).

A partir do diálogo mantido entre os participantes favorecia-se o desenvolvimento de habilidades reflexivas sobre as ações desempenhadas durante as atividades sugeridas. Como mostrado na Figura 4.1, o espaço do laboratório e da sala de aula estavam conjugados em um mesmo ambiente.

O deslocamento dos alunos entre os dois prédios da escola, nos quais estudam, separadamente, os alunos de Ensino Fundamental I e Ensino Fundamental II e Médio, é dificultado no período noturno, horário no qual o prédio em que se localiza o laboratório de Química permanece fechado, por não haver alunos do Ensino Fundamental I na escola nesse período.

A participação de alunos do Ensino Médio noturno foi impossibilitada, restringindo a pesquisa aos alunos do período matutino (não havia Ensino Médio no período vespertino, nessa escola). A freqüência dos alunos nas aulas de Química em que se desenvolveram as atividades variou, chegando a participarem apenas $50 \%$ dos matriculados. 
Capítulo 4 - Metodologia

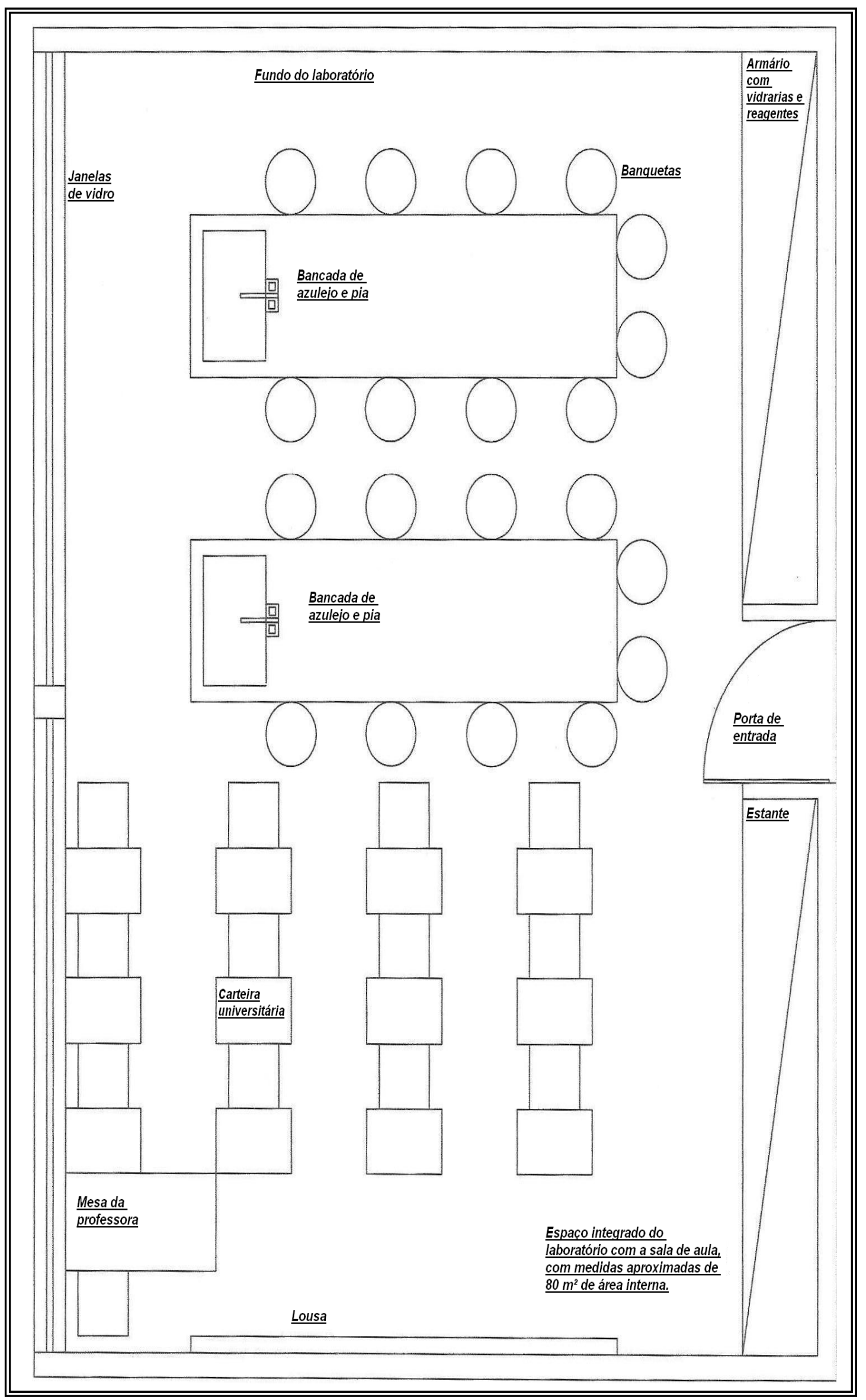

Figura 4.1. Mapa da disposição física do laboratório de Química. 
Nas Figuras 4.2 e 4.3, nota-se a existência de armários, bancadas, mapas, equipamentos de laboratório, reagentes, carteiras e lousa, em um ambiente arejado, espaçoso, bem iluminado, facilitando o acesso aos materiais que serão utilizados durante as aulas e experimentações.

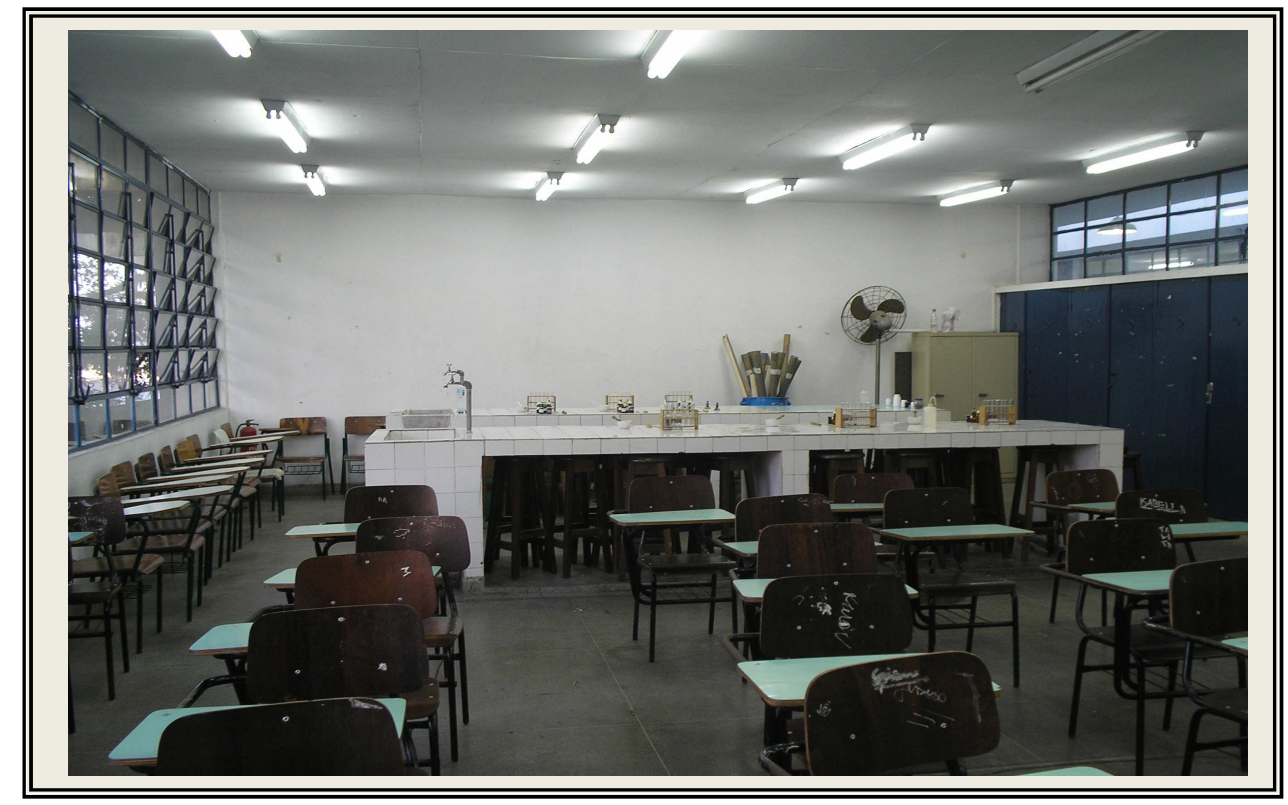

Figura 4.2. Vista frontal 1 do laboratório

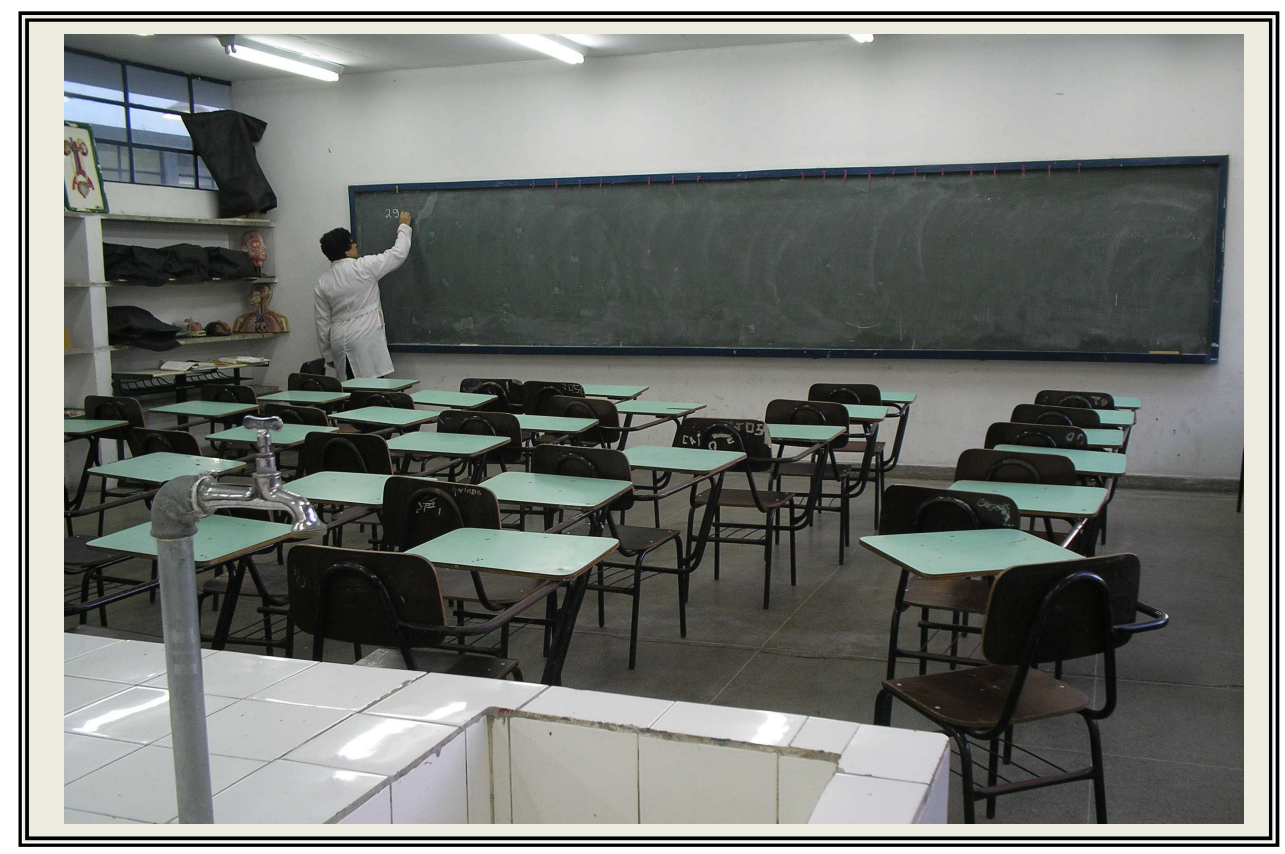

Figura 4.3. Vista frontal 2 do laboratório

Na Figura 4.4, observam-se, sobre as bancadas, os materiais que serão utilizados na atividade experimental "Investigação das características de um sistema em estudo antes e 
após a transformação" ${ }^{28}$. Destaca-se o tamanho das bancadas e sua proximidade com as janelas, como também a incidência de luminosidade e arejamento do espaço, o qual contém bancos para acomodação dos alunos, alocados sob as bancadas.

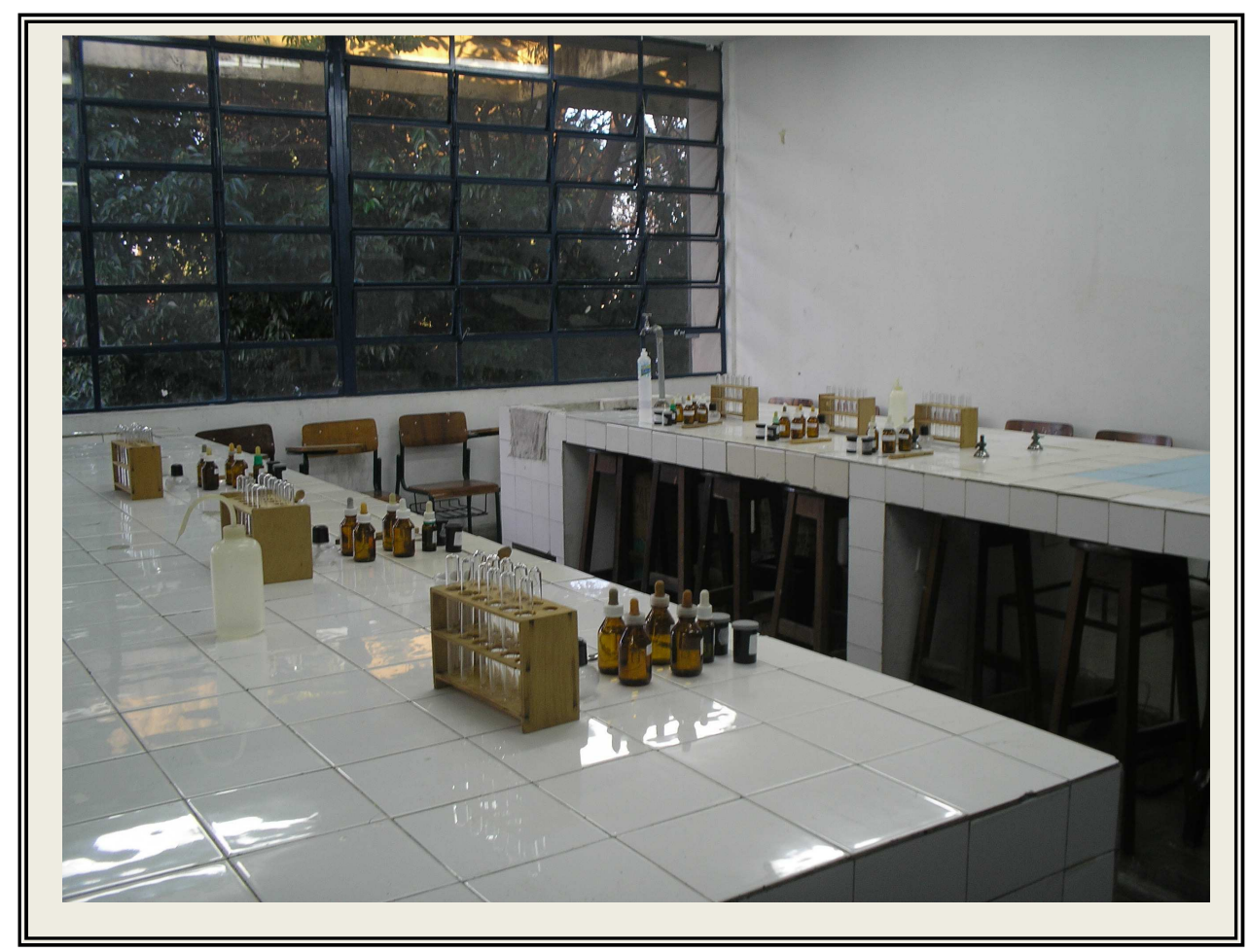

Figura 4.4. Vista das bancadas do laboratório

Ao observar as Figuras 4.1 a 4.4, nota-se que o laboratório é um ambiente adequado ao desenvolvimento da aprendizagem, promovida pelo “(...) estabelecimento de relações entre as características observáveis ou experimentalmente determináveis de um objeto sob estudo (...)" (LAKATOS \& MARCONI, 1983, p. 95).

A professora-pesquisadora, ao se defrontar com o espaço físico do laboratório da escola, conjugado com sala de aula e com equipamentos disponíveis para realização das atividades, percebeu que esse seria o ambiente adequado para realização deste trabalho de pesquisa (observar Figuras 4.1 a 4.6), pois o mesmo proporcionaria aos alunos momentos diferenciados daqueles a que estão acostumados em seu cotidiano escolar.

Para tanto, a intervenção da professora-pesquisadora na realidade da sala de aula requer um processo reflexivo para melhoria de suas práticas como docente num processo dialógico de construção do conhecimento. Assim, a professora-pesquisadora participa como co-protagonista empregando metodologias educacionais investigativas, em que os sujeitos participantes se expressam e se comunicam interferindo no cotidiano da sala de aula, rompendo com uma concepção de neutralidade e de controle das circunstâncias da

\footnotetext{
${ }^{28}$ Atividade constante do Capítulo 1 do PROQUIM, a qual se pode ler no anexo B1 na página 164.
} 
pesquisa, integrando-se ao coletivo da escola e promovendo seu próprio desenvolvimento profissional. Um momento de interação entre a professora-pesquisadora e os alunos e entre os próprios alunos está representado nas Figuras 4.5 e 4.6.

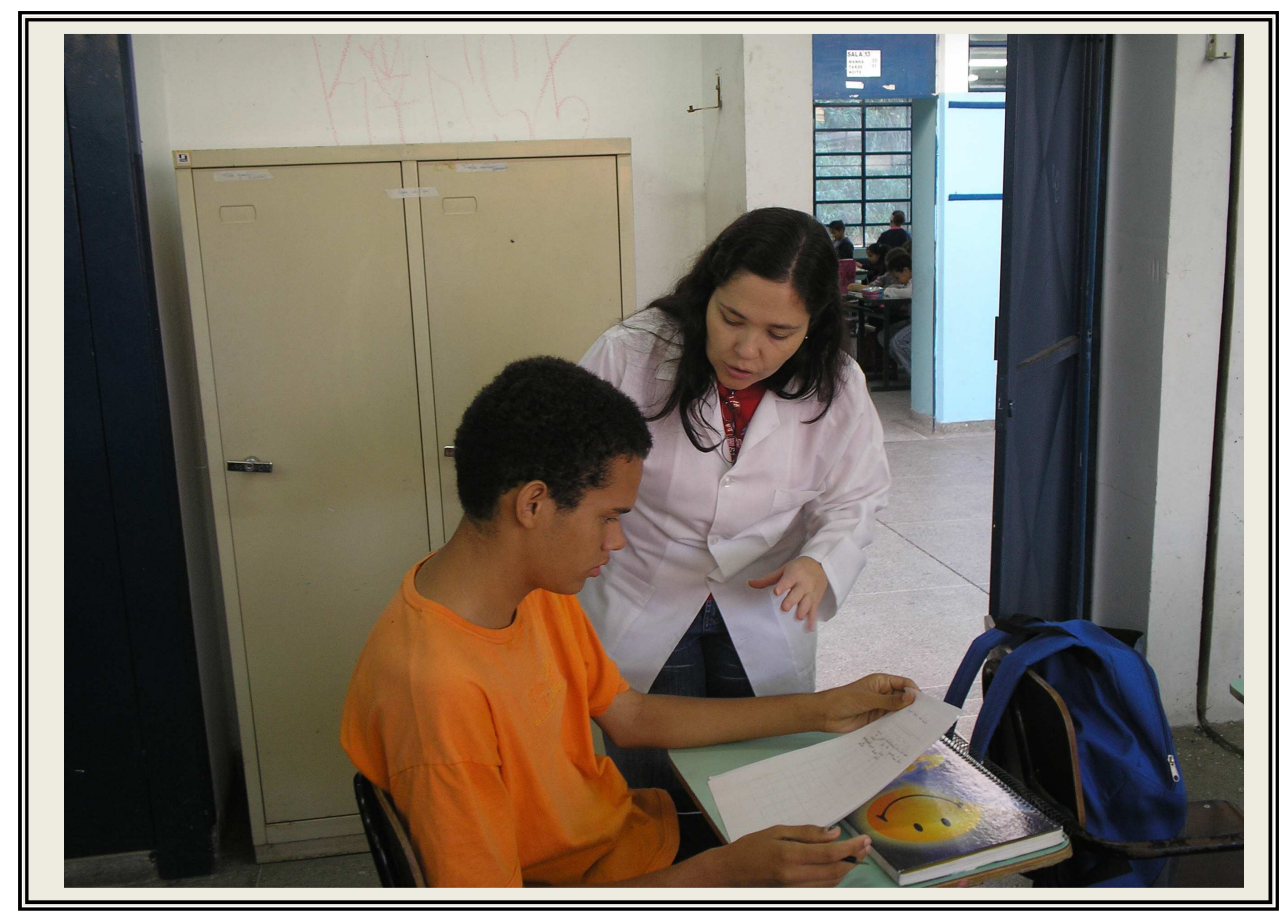

Figura 4.5. Momento de interação professora-aluno

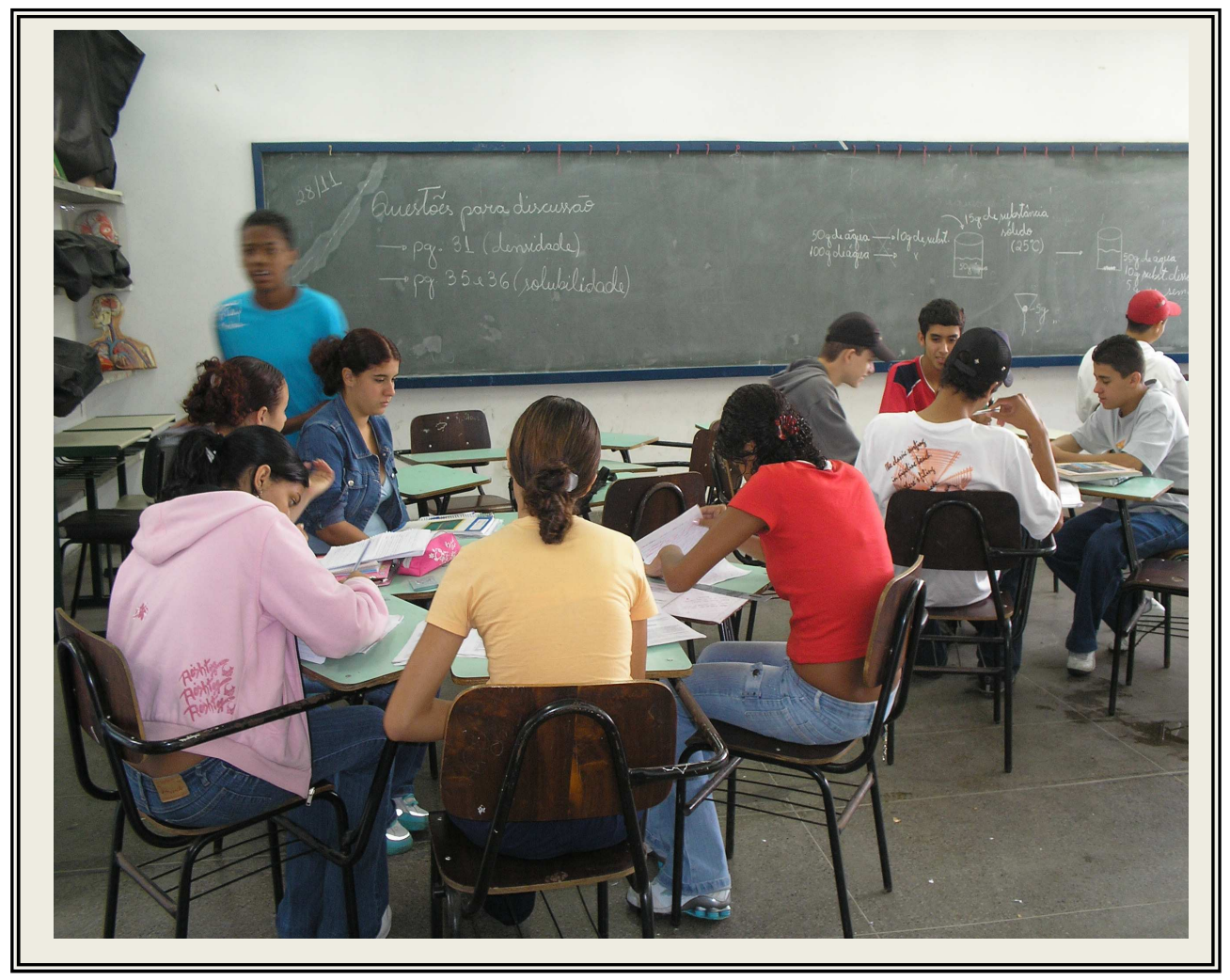

Figura 4.6. Momento de interação aluno-aluno 
A integração existente entre os grupos é beneficiada pela promoção do relacionamento professor-aluno e aluno-aluno, todos inseridos em um mesmo grupo de estudo em busca da construção de seus conhecimentos, confirmando as considerações de ROSA \& TOSTA (2005, p. 257):

“(...) o laboratório de Química configura-se claramente como o lugar que explica a existência social do químico e isso é corroborado também na escola, onde existe a necessidade de um espaço físico para a existência da Química".

“(...) essa complementaridade se dá no laboratório, na interação entre os pares, na socialização do conhecimento produzido. Essa é a face mais nítida da ciência Química, que produz um conhecimento que articula macro e micro, fenômeno e explicação, empírico e teórico (...)."

Essas autoras justificam o uso do laboratório para o ensino de Química não só pela percepção social do papel do químico na escola, mas também pela consideração da possibilidade de que a aprendizagem científica, feita através de articulações de conceitos científicos com a química que reconhecemos no cotidiano, possa ocorrer satisfatoriamente em diferentes ambientes da escola.

As atividades em laboratório desenvolvidas durante nosso estudo são adequadas à aprendizagem científica, porque foram conduzidas de forma a permitir a permanente socialização dos saberes construídos, favorecendo a interação dialógica entre os atores envolvidos nos processos de ensino e aprendizagem e não devido somente ao espaço físico disponível. De fato, MOREIRA (1980, p. 33) afirma que “(...) em um ambiente organizado social e culturalmente, no qual ações mudam constantemente, significados são adquiridos, trocados e compartilhados (...)".

Deste modo, como apresentado nas Figuras 4.1 a 4.6, houve possibilidade de se criar um ambiente escolar adequado para o desenvolvimento desta pesquisa, conjugando os aspectos físicos às interações sociais, contribuindo para a promoção da aprendizagem dos alunos.

\subsubsection{O material instrucional}

O material escolhido para o desenvolvimento do curso, o PROQUIM (MAZON et al., 1986), aborda conteúdos relativos às reações químicas. Sua concepção ausubeliana permite que os alunos expressem suas opiniões a partir das observações feitas e durante a 
ação reflexiva exercida em momentos de estudo, favorecendo a construção de conhecimentos através da interação dos alunos com o grupo do qual fazem parte.

Esse tipo de estratégia favorece a formação de novos conceitos, ou mesmo, a fixação de novas idéias, através de experimentações e discussões para a socialização das interpretações feitas, ou seja, "(...) se todas as coisas e idéias se movem, se transformam e se desenvolvem, significa que constituem processos (...)" (LAKATOS \& MARCONI, 1983, p. 74). RATNER (1995, p. 61) apóia essa afirmação ao dizer que “(...) a consciência só surge da luta por compreender, criar e transformar determinada realidade social (...)", podendo ser "(...) o pensamento estimulado por diversos tipos de linguagens (...)".

A concepção ausubeliana do PROQUIM favorece o envolvimento dos alunos com as atividades ali propostas. Esse fato ocorre devido ao material apresentar seu conteúdo articulado ao conhecimento já existente na estrutura cognitiva dos educandos.

Quando os educandos entram em contato com o material demonstram interesse em utilizá-lo, pois percebem que o conteúdo está ali apresentado de forma significativa considerando o que o aluno já conhece.

O conceitos estão organizados hierarquicamente no material instrucional, partindo de conceitos mais abrangentes, como o conceito de transformação para que os educandos, através de processos interativos de construção do conhecimento, possam se relacionar e compartilhar experiências com outras pessoas do grupo e, desse modo, ancorar um maior número de atributos ao conceito subsunçor, presente em sua estrutura cognitiva.

Os conflitos gerados na estrutura cognitiva dos educandos, sua zona de desenvolvimento proximal, pode facilitar a evolução do conceito de transformação para outros mais específicos, como o conceito de transformação química.

\subsection{Coleta de dados}

As atividades propostas no material utilizado foram realizadas em grupo ou individualmente e versavam sobre transformações dos materiais. Para o reconhecimento da formação de novos materiais, foram abordadas propriedades físicas (ponto de ebulição, ponto de fusão, densidade e solubilidade), que permitem a identificação de materiais e sua diferenciação entre substâncias e misturas. 
A resolução destas atividades foi escrita em material à parte para posterior entrega à professora-pesquisadora; os alunos participaram de discussões coletivas que foram registradas por escrito.

Todas as informações foram coletadas durante os anos letivos de 2006 e 2007 e das mensagens expressas pelos alunos, surgiram categorias e subcategorias, que foram interpretadas com base na análise de conteúdo proposta por BARDIN (2006), delineando a modificação do domínio da linguagem científica dos aprendizes, do início ao final dos trabalhos realizados.

BARDIN (2006, p. 93 e 96) afirma que ao se fazer uma pré-análise do material que será investigado, faz-se necessário escolher detalhadamente, através de procedimentos exploratórios, as atividades que possuam interligação com as hipóteses levantadas e que irão precisar as dimensões e direções de análise a que o trabalho se propõe. Assim, selecionamos algumas atividades a fim de analisar a modificação das concepções dos educandos acerca dos processos de transformações dos materiais.

As atividades que constam deste material instrucional contêm "palavras indutoras", que na acepção de BARDIN (2006, p. 48), servem como desencadeadoras das respostas dos alunos ("palavras induzidas"). As palavras indutoras não são utilizadas no sentido de que o aluno forneça respostas (palavras induzidas) retiradas literalmente do conteúdo do PROQUIM. Elas servem como ponto de partida para que o aluno busque em sua vivência e em sua visão de mundo um repertório que permita dar sentido ao que lhe é perguntado, formando, desse modo, seus conceitos quanto às propriedades particulares dos materiais, partindo de observações no âmbito macroscópico e relacionando-as a modelos no nível microscópico.

As atividades selecionadas para a investigação envolveram a construção do conceito de transformação, em que se partiu de representações amplas do conceito (inclusivas; AUSUBEL, 1982) para que, através da adição de novos atributos aos conceitos subsunçores, atinja-se novos significados, mais diferenciados, levando a uma conceituação cada vez mais elaborada.

\subsubsection{As aulas de Química e as atividades selecionadas como fonte de dados}

Inicialmente, os alunos foram convidados a participar de um projeto no qual suas atividades seriam utilizadas como fonte para coleta de dados da Dissertação de Mestrado 
de sua professora de Química. Prontamente, a maioria dos alunos julgou interessante o que estava sendo proposto, porém alguns resistiram a participar, principalmente quando lhes foi comunicado que teriam atividades a serem feitas individualmente, em suas casas.

Apesar do número de aulas de Química na rede pública estadual de São Paulo ser insuficiente para abarcar todo o conteúdo que é proposto pela Secretaria Estadual da Educação ${ }^{29}$, houve necessidade de se estabelecer um contrato didático, em que os alunos comprometeram-se a utilizar-se de seu tempo livre para dedicar-se ao estudo da Química, pois não estavam habituados a realizar atividades extra-classe. Outros fatores que limitaram algumas aulas:

aulas simples: insuficientes para a realização das atividades no mesmo dia;

horário das aulas coincidindo com o intervalo dos alunos do Ensino Fundamental I, ocasionando muito barulho no laboratório, que fica neste mesmo prédio, acima da cantina, e tem suas janelas voltadas para o pátio externo da escola; muitas vezes os alunos precisavam repetir o que diziam;

prédios do laboratório e sala de aula das outras disciplinas, distintos, uma vez que o laboratório se localiza em prédio diferente daquele em que eram ministradas as demais aulas do currículo;

vazamento em uma das pias e no telhado em dias de chuva, deixando o laboratório alagado.

Dentre as atividades sugeridas pelo PROQUIM e aplicadas aos alunos, algumas foram selecionadas para análise (Tabela 4.1), conforme o conceito que se queria observar.

Tabela 4.1 - Atividades selecionadas como fonte de coleta de dados

\begin{tabular}{|c|c|c|c|}
\hline & Atividades analisadas & Conceito & Objetivo \\
\hline $1 \underline{a}$ & $\begin{array}{l}\text { Construção de Tabelas individuais: } \\
\text { "citações de transformação" }\end{array}$ & Transformação & $\begin{array}{l}\text { Observar as concepções prévias dos } \\
\text { educandos acerca do conceito de } \\
\text { transformação }\end{array}$ \\
\hline 2a & $\begin{array}{l}\text { Construção de Tabelas coletivas: } \\
\text { "citações de transformação" }\end{array}$ & Transformação & $\begin{array}{l}\text { Observar a modificação na construção } \\
\text { do conceito de transformação após a } \\
\text { ação colaborativa da professora e dos } \\
\text { outros alunos }\end{array}$ \\
\hline $3 \underline{a}$ & $\begin{array}{l}\text { "Aqueceu-se um sólido vermelho num tudo } \\
\text { de ensaio. Depois de algum tempo de } \\
\text { aquecimento detectou-se a liberação de um } \\
\text { gás incolor e a formação de um líquido } \\
\text { prateado. Pergunta-se: Ocorreu reação } \\
\text { química? Qual é a evidência?" }\end{array}$ & $\begin{array}{l}\text { Transformação } \\
\text { química }\end{array}$ & $\begin{array}{l}\text { Observar as respostas dos alunos a } \\
\text { respeito do conceito de transformação } \\
\text { química após a ação colaborativa da } \\
\text { professora e dos outros alunos }\end{array}$ \\
\hline $4 \underline{a}$ & $\begin{array}{l}\text { "Quando se aquece a água há liberação de } \\
\text { um gás. Está ocorrendo uma reação química? } \\
\text { Explique sua resposta." }\end{array}$ & $\begin{array}{l}\text { Transformação } \\
\text { química }\end{array}$ & $\begin{array}{l}\text { Observar as respostas dos alunos a } \\
\text { respeito do conceito de transformação } \\
\text { química após a ação colaborativa da } \\
\text { professora e dos outros alunos }\end{array}$ \\
\hline
\end{tabular}

${ }^{29}$ Ver Tabela 3.3 no Capítulo 3 desta Dissertação, na página 72. 


\subsubsection{Aplicação: $1^{\mathrm{a}}$ e $2^{\mathrm{a}}$ atividades selecionadas como fonte de coleta dados}

Primeiramente, a professora-pesquisadora realizou a leitura de um texto intitulado " $A$ Química é Velha?" ${ }^{30}$, o qual fazia referência às transformações oriundas do cotidiano e sua relação com o meio. Essa fase foi ao encontro da contextualização do conteúdo que seria abordado logo na seqüência, antes dos alunos serem dirigidos a outras atividades.

Tabela 4.2 - Atividades solicitadas para observação de concepções prévias

\begin{tabular}{|c|c|c|c|}
\hline Atividade solicitada & Realização & Evocações & Aulas \\
\hline Leitura do Texto & Professora-pesquisadora & --.- & \multirow{3}{*}{02 aulas } \\
\hline $\begin{array}{l}1^{\text {a }} \text { atividade: Tabela } \\
\text { individual }\end{array}$ & 118 Alunos & 114 & \\
\hline $\begin{array}{l}2^{\mathrm{a}} \text { atividade: Tabela } \\
\text { coletiva }\end{array}$ & $\begin{array}{l}\text { Professora-pesquisadora e } \\
136 \text { alunos }\end{array}$ & 41 & \\
\hline
\end{tabular}

A professora-pesquisadora solicitou aos alunos que construíssem Tabelas Individuais que refletissem transformações de suas vidas diárias e que, dentre elas, destacassem apenas dez e as listassem em outra tabela apresentando em seu lado esquerdo a transformação abordada e do lado direito como eles reconheceram que realmente se tratava de uma transformação ${ }^{31}$.

Nesse momento os educandos ficaram confusos e percebemos que resolveram seguir o mesmo modelo de tabela apresentado no material instrucional. Enquanto construíam suas tabelas também consultavam seus colegas para saber o tipo de transformação estavam descrevendo e como estavam justificando o reconhecimento da transformação.

As transformações listadas resultaram em 34 diferentes evocações (citações de 35 alunos das duas turmas do ano de 2006) ) $^{32}$ e mais 80 diferentes evocações (citações de 83 alunos participantes das três turmas do ano de 2007) ${ }^{33}$.

Num segundo momento, em aulas simples e realizadas em outro dia, as tabelas foram construídas coletivamente ${ }^{34}$ em discussões mediadas pela professora-pesquisadora, para que os alunos pudessem expor idéias que suscitassem discussões relacionadas ao fato de que uma transformação é um processo dinâmico e, portanto, resulta em modificações nos

\footnotetext{
${ }^{30}$ Texto I-1 do capítulo 1 do PROQUIM, constante do anexo B1 na página 164.

${ }^{31}$ Atividade I-1 - capítulo 1 do PROQUIM, constante do anexo B1 na página 166.

${ }_{32}$ Tabela individual contendo evocações dos alunos do ano letivo de 2006, referentes a transformações de sistemas e constante do anexo C1, na página 199.

33 Tabela individual contendo evocações dos alunos do ano letivo de 2007, referentes a transformações de sistemas e constante do anexo C2, na página 201.

${ }^{34}$ Cf. nota 15 deste capítulo.
} 
Capítulo 4 - Metodologia

atributos dos sistemas. No ano de 2006 houve 53 participações e 16 diferentes proposições e, no ano de 2007, 83 participantes e 25 diferentes evocações, compondo um quadro geral de cada turma/série participante.

Para compor o quadro coletivo de cada turma os educandos foram colocando suas sugestões de transformação e como fizeram para reconhecê-las. A cada sistema mencionado pelos educandos surgia uma discussão, mediada pela professora, na busca por mais informações que pudessem esclarecer como se deu o reconhecimento do processo em transformação.

\subsubsection{Aplicação: $3^{\mathrm{a}}$ e $4^{\mathrm{a}}$ atividades selecionadas como fonte de coleta dados}

A $3^{\underline{a}}$ e $4^{\underline{a}}$ atividades selecionadas como fonte de coleta de dados foram respondidas pelos alunos somente após o desenvolvimento do Guia Experimental I-1 ${ }^{35}$ - "O que é uma reação química" - que solicitava aos estudantes a investigação de alguns sistemas com a finalidade de identificar propriedades que poderiam facilitar a identificação de formação de novos materiais. Para tanto, foram realizados onze procedimentos experimentais, listados em uma tabela de dados ${ }^{36}$ que requeriam observações referentes aos sistemas em estudo, suas características iniciais e finais e comparações entre elas.

Antes do início dos procedimentos experimentais, a professora-pesquisadora conversou com os alunos sobre as normas de segurança em um laboratório e demonstrou os experimentos 1 e 2 , porque os alunos apresentaram dificuldades em manusear materiais como tubos de ensaio, lamparinas e pinças.

Os alunos realizaram novamente os experimentos 1 e 2 e deram prosseguimento aos demais, com auxílio da professora-pesquisadora, que mediou as ações de alguns grupos que tiveram maiores dificuldades em lidar com os materiais e registrar suas observações.

\section{Ressalvas:}

os alunos ficaram ansiosos para "lidar com fogo" e realizar os experimentos;

os procedimentos experimentais foram desenvolvidos em três dias seguidos, porém em aulas não seqüenciadas;

\footnotetext{
${ }^{35}$ O Guia Experimental I-1 consta do Capítulo 1 do material instrucional, o qual encontra-se no anexo B1, na página 168.

${ }^{36}$ O Guia Experimental I-1 - IV - Tabela de dados - Capítulo 1 do material instrucional encontra-se no anexo B1, na página 171.
} 
os alunos procederam à análise de dados e propuseram conclusões na mesma aula;

os alunos tiveram dificuldades em compreender o significado de precipitado, solúvel, insolúvel, tema que acabou sendo discutido no mesmo momento com a turma, para que nenhuma dúvida prosseguisse para outras ocasiões;

a questão 2 das Conclusões $^{37}$, que se referia ao flash de máquinas fotográficas antigas, apresentou-se inadequada às concepções dos educandos;

os alunos ficaram curiosos para saber os nomes dos materiais que estavam utilizando;

a utilização da máquina fotográfica e do gravador inibiu a conduta de alguns alunos.

Os exercícios destacados para análise da construção do conceito de transformação foram:

"Aqueceu-se um sólido vermelho num tudo de ensaio. Depois de algum tempo de aquecimento detectou-se a liberação de um gás incolor e a formação de um líquido prateado. Pergunta-se: Ocorreu reação química? Qual é a evidência?"38

"Quando se aquece a água há liberação de um gás. Está ocorrendo uma reação química? Explique sua resposta."

Antes de responder aos exercícios propostos, a professora-pesquisadora e os alunos discutiram sobre as evidências que surgem quando um material passa por um processo de transformação e que estas não são garantia de que realmente tenha ocorrido uma reação química, caracterizada pela formação de novos materiais.

Em grupos organizados por afinidades entre os educandos, partiu-se para a resolução dos exercícios propostos ao final dos procedimentos experimentais. Deste modo, os alunos puderam expor suas idéias e ressignificar os conceitos pré-existente em sua estrutura cognitiva.

\footnotetext{
${ }^{37}$ Guia Experimental l-1 - VI - Conclusões - Capítulo 1 do material instrucional, encontra-se no anexo $B 1$, na página 173 .

${ }^{38}$ Guia Experimental I - 1 - VII - Exercícios - Capítulo 1 do material instrucional, encontra-se no anexo B1, na página 174.

${ }^{39}$ Cf. nota 38 deste capítulo.
} 


\subsubsection{Questionamentos aos escritores do material instrucional}

Durante a escrita desta pesquisa, vimos a importância de conhecer mais sobre a construção do material instrucional utilizado. Então, resolvemos questionar seus autores, solicitando que nos respondessem algumas questões referentes à sua construção ${ }^{40}$.

1. Como se formou o grupo que escreveu o PROQUIM?

2. O que levou o grupo a escrever o PROQUIM?

3. Com que intenção o PROQUIM foi escrito?

4. Quais foram as dificuldades encontradas ao escrevê-lo?

5. Quais foram as impressões encontradas após escrevê-lo?

6. Vocês encontraram dificuldades ou limitações ao aplicá-lo em sala de aula?

7. Entre vocês escritores e aplicadores do PROQUIM, qual era a condição social dos alunos onde se aplicava o material?

8. Vocês têm conhecimento de outros professores da rede pública ou particular de ensino que trabalharam ou ainda trabalham aplicando o PROQUIM?

9. Quais são os resultados obtidos por estes professores?

10. Por que o material não terminou de ser escrito e editado?

11. Vocês têm alguma mensagem para deixar aos professores que trabalham ou desejam trabalhar com este material?

Quadro 4.1 - Questionário enviado aos idealizadores e escritores do PROQUIM

Dessa forma, um dos capítulos desta Dissertação refere-se ao uso do PROQUIM como material instrucional potencialmente significativo e como fonte de investigação para posterior coleta de dados. Neste capítulo pode-se observar que o material propõe a construção coletiva do conhecimento e favorece momentos de interação entre a professora e os educandos com a finalidade de trocas de experiências provenientes dos conhecimentos prévios de cada um.

\subsection{Análise de dados}

Para análise do conteúdo expresso nas mensagens contidas nas atividades selecionadas para coleta de dados ${ }^{41}$, utilizaremos como referencial teórico, para "formação de conceitos", os escritos de VIGOTSKI (2005) e o descrito no material do PROQUIM ${ }^{42}$. A

\footnotetext{
${ }^{40}$ Os questionários foram enviados aos idealizadores do PROQUIM, por e-mail, e as cópias das entrevistas dos autores que as responderam constam dos anexos A1 e A2, nas páginas 159 e 161 , respectivamente.

${ }^{41}$ Conforme atividades apresentadas na Tabela 4.1.

${ }^{42}$ Projeto de ensino desenvolvido por professores de Química, na década de1980.
} 
análise da formação do conceito de transformação foi dividida em quatro categorias, sendo denominadas, respectivamente, "Amontoados Sincréticos", "Pensamento por Complexos", "Pensamento Conceitual" e "Outros".

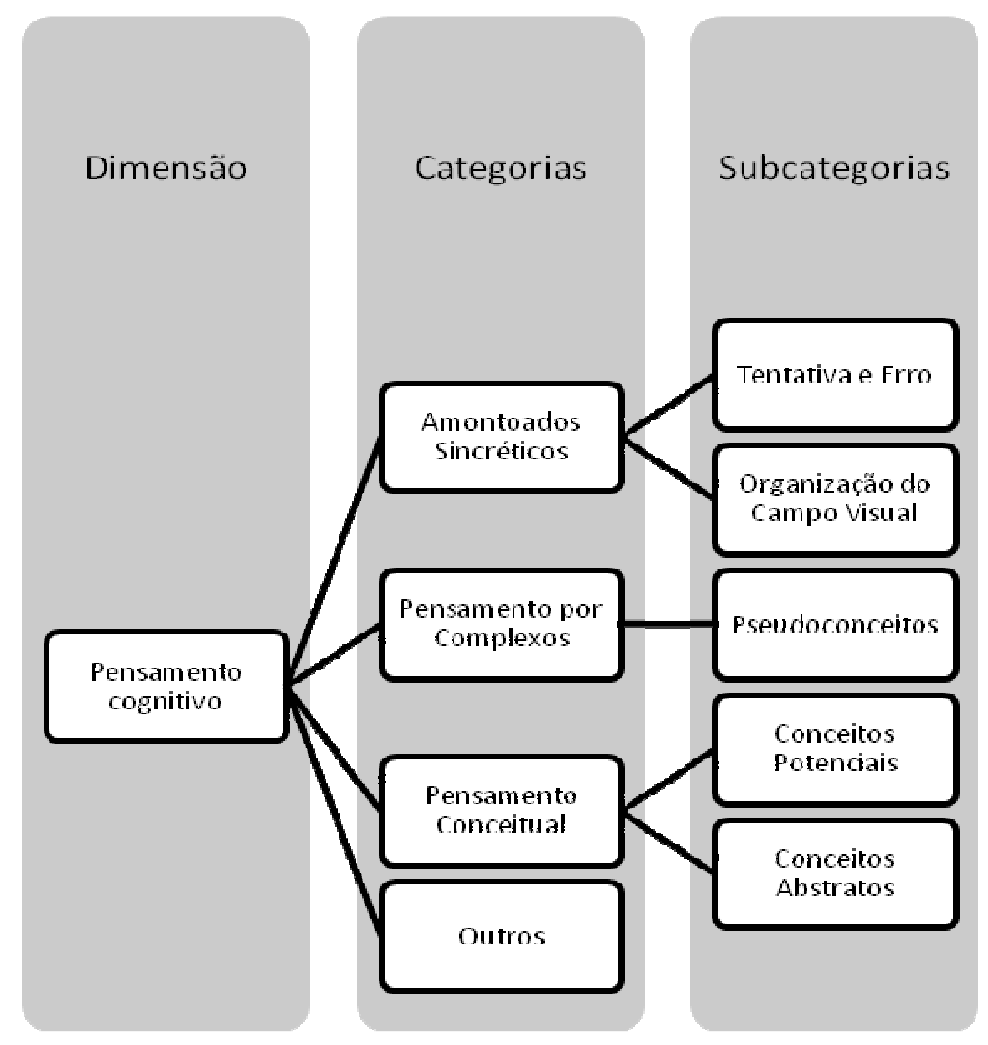

Figura 4.7 - Categorias e Subcategorias para análise da formação do conceito de transformação ${ }^{43}$

A categoria "Amontoados Sincréticos" encontra-se subdivida em duas subcategorias: "Tentativa e Erro" e "Organização do Campo Visual". Essa fase é caracterizada por um aglomerado de informações e imagens, detectadas pelos educandos apenas no campo sensorial (subcategoria "Organização do Campo Visual") ou por relações criadas ao acaso para poder organizar informações referentes aos sistemas em estudo (subcategoria "Tentativa e Erro").

$\mathrm{Na}$ segunda categoria, "Pensamento por Complexos", encontra-se a subcategoria "Pseudoconceito", no qual indicaremos as justificativas dos educandos para os sistemas em transformação que mais se aproximarem do pensamento objetivo, ou seja, será observada uma seqüência lógica de pensamento em que os alunos indicaram propriedades reais dos

${ }^{43}$ Diagrama elaborado conforme as etapas de formação de conceitos proposto por VIGOTSKI (2005). 
sistemas em análise. Nessa subcategoria ("Pseudoconceito"), os educandos já expressam suas observações de forma coerente e associam informações, criando vínculos entre suas percepções e as transformações que ocorrem nos sistemas.

A categoria "Pensamento Conceitual" apresenta as justificativas dos educandos que mais se aproximam da formação aceita para o conceito de transformação, reunindo as justificativas dos alunos em torno das expressões que mais se aproximam do seu significado. Esta categoria se subdivide em duas subcategorias, "Conceitos Potenciais" e "Conceitos Abstratos".

Na subcategoria "Conceitos Potenciais" estão elencadas as respostas dos educandos geradas por atributos perceptíveis e relacionáveis a uma transformação semelhante, ou seja, que pode ser observada no concreto.

Já na subcategoria "Conceitos Abstratos" estão agrupadas as respostas dos educandos que descrevem as peculiaridades dos sistemas em transformação, unificando suas justificativas de tal forma que se percebe a busca por atributos pertinentes a outros sistemas para justificarem suas respostas na situação determinada. Neste ponto, os educandos que tiverem justificativas de reconhecimento de transformações nos sistemas, classificáveis nesta categoria, serão capazes de relacionar, comparar e sintetizar suas observações e reuní-las para uso em situações diferentes das vivenciadas anteriormente.

A categoria "Outros" foi assim chamada para poder indicar as repostas dos educandos que não se relacionavam às atividades propostas para ressignificação do conceito de transformação.

A análise discutirá a construção do conceito de transformação, abordando as transformações dos materiais do ponto de vista macroscópico, ou seja, considerando as observações dos educandos quanto às evidências de transformação dos sistemas antes e após o processo em estudo. Evidentemente, se observáveis, essas evidências compreendem apenas o âmbito fenomenológico das observações, daí pôde-se criar as subcategorias dinâmico e estático ${ }^{44}$, como observado na Figura 4.8, para os sistemas propostos na categoria Amontoados Sincréticos.

Por dinâmico entendem-se os processos em que os alunos se referiram aos sistemas através de evidências observadas antes e após sua transformação ou quando citaram a evocação mencionando um processo de transformação. Na subcategoria estático foram

${ }^{44}$ Por dinâmico entende-se as características apresentadas pelo objeto sob estudo, antes e após a sua transformação. Por estático entende-se a referência a um processo em que não se reconhece o estado inicial e final da transformação. 
agrupadas as evocações que remetiam a um procedimento finalizado, ou seja, no qual não era possível identificar as etapas do processo de transformação no sistema proposto.

Para cada categoria, serão interpretadas evocações sugeridas pelos educandos na $1^{\underline{a}}$ e $2^{a}$ atividades selecionadas como fonte para coleta de dados, como também para as questões propostas após realização coletiva de procedimentos experimentais (3 $3^{\underline{a}}$ e $4^{\underline{a}}$ atividades), reunindo-se grupos de elementos comuns aos relatos feitos pelos alunos e percebidos pelos sentidos. A análise do conteúdo que aparece nas evocações "(...) pode realizar-se a partir das significações que a mensagem fornece (...)" (BARDIN, 2006, p. 129).

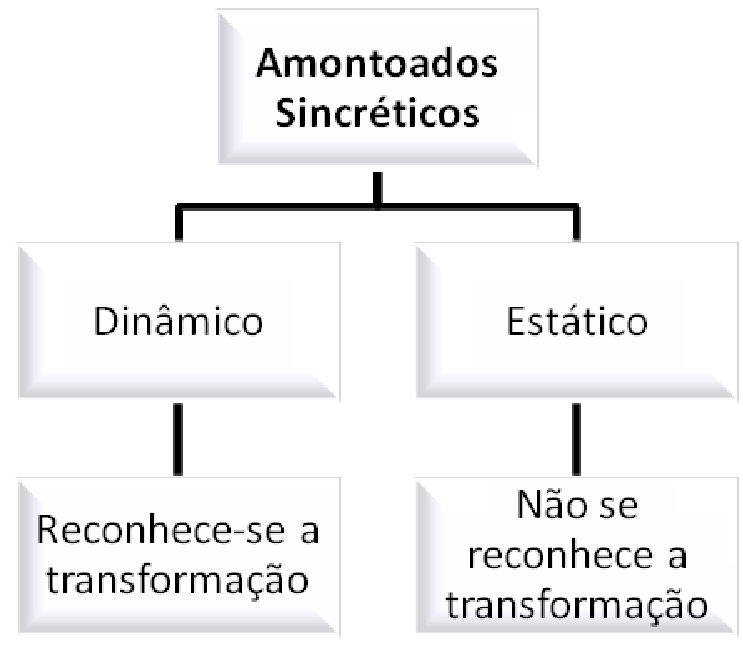

Figura 4.8. Subcategorias de análise das proposições dos alunos para a categoria amontoados sincréticos, no âmbito macroscópico das observações.

Ainda na análise da formação do conceito de transformação, conforme categorias e subcategoria apresentadas nas Figuras 4.7 e 4.8, serão analisadas as atividades indicadas na Tabela 4.1, por apresentarem o pensamento do aluno constituído a partir da interação entre o senso comum, concebido por meio da educação informal e o conhecimento escolar, construído a partir de um processo de ensino e aprendizagem cooperativo entre as pessoas participantes desse processo (VIGOTSKI, 2005).

Além dos dados analisados coletivamente nas atividades realizadas pelos educandos dos anos de 2006 e 2007, uma análise individualizada será promovida com atividades de cinco educandos, com o objetivo de observar a modificação das concepções prévias existentes na estrutura cognitiva dos mesmos. Para fins de análise o aluno do ano de 2006 será chamado de Alex_2006 e os alunos de 2007 serão chamados de Carlos_2007, e Elena_2007. Seus nomes foram modificados com a finalidade de preservar a identidade dos educandos. 
Como a 2a atividade analisada foi construída coletivamente, então, analisaremos para estes cinco educandos as atividades $1^{\underline{a}}, 3^{\underline{a}}$ e $4^{\underline{a}}$, e as categorias e subcategoria empregadas para análise serão as mesmas, ou seja, aquelas apresentadas nas Figuras 4.7 e 4.8.

GASPAR (1992), em artigo escrito a partir das indicações da teoria de Vigotski, discute a interação existente entre a educação formal e a informal, construídas, respectivamente, no ambiente escolar e fora dele. Segundo esse autor, a educação formal e a informal se interrelacionam por serem apresentadas aos educandos a partir de experiências que ocorrem no dia-a-dia, uma servindo à outra como fundamento essencial ao desenvolvimento de conceitos mais específicos, a partir das concepções espontâneas dos alunos, ou seja, a formação dos conceitos é um processo que se constitui de forma diferenciada para cada estudante, mediante seus próprios esforços mentais (VIGOTSKI, 2005), resultando em um aprendizado mais elaborado e significativo. 


\section{Capítulo 5}

\section{Resultados e Discussão}

“O professor deve estar atento à sua função primeira de saber apresentar condições favoráveis à apropriação, por parte do alunado, de conhecimentos acumulados e socialmente tidos como relevantes. São estes conhecimentos que servirão de instrumental para seu agir no mundo, para o pensar sobre si e sobre as coisas da sua vida." (VASCONCELOS et al., 2005, p. 6) 


\subsection{Análise dos dados referentes à ressignificação do conceito de transformação, conforme proposto por VIGOTSKI (2005)}

A análise sobre a ressignificação do conceito de transformação em educandos de primeiro ano de Ensino Médio dos anos de 2006 e 2007 se dará a partir da concepção prévia deste signo presente em suas estruturas cognitivas até a atribuição de um sentido peculiar para este. Ou seja, será verificado se houve ou não o desenvolvimento de um conhecimento significativo e sua modificação para um símbolo culturalmente estabelecido, através da construção coletiva do conhecimento, mediado pela professora de Química da Unidade Educacional.

"(...) o momento de maior significado no curso do desenvolvimento intelectual, que dá origem às formas puramente humanas de inteligência prática e abstrata, acontece quando a fala e a atividade prática, então duas linhas completamente independentes de desenvolvimento, convergem. (VIGOTSKI, 1991, p. 27)"

VIGOTSKI (1991), neste excerto, discute sobre o desenvolvimento intelectual dos seres humanos e a convergência de suas habilidades cognitivas no uso de instrumentos de representação da linguagem.

A linguagem utilizada pelos aprendizes concebe a expressão do pensamento por meio de ações que tendem a se integrar com o aprimoramento da inteligência, por meio de práticas colaborativas do pensar e do agir de cada um isoladamente ou como parte inserida no todo.

Com efeito, a prática de ações colaborativas no ambiente escolar e presentes nos processos de ensino e aprendizagem podem contribuir para que os educandos se apropriem de conceitos químicos, diferenciando seus atributos através de características que foram se inserindo em sua estrutura cognitiva e desenvolvendo a linguagem encontrada no meio social do qual estes alunos fazem parte.

Para observar se o desenvolvimento dos signos usados pelos educandos, durante as etapas de formação de conceitos químicos, encontrou significado no ambiente socializador existente no meio educacional, analisamos suas respostas em quatro atividades distintas e as comparamos com a síntese proposta ao final do Capítulo 1 do material instrucional do PROQUIM (MAZON et al., 1986, p. 5):

"O reconhecimento de uma transformação pode ser feito através da comparação de algumas características do(s) material(is) antes e após a ocorrência da transformação que ocorre numa porção delimitada do sistema em estudo. A descrição do sistema antes da transformação define o estado inicial do sistema enquanto a descrição feita após a transformação define 0 
estado final do sistema. Portanto, a comparação entre o estado inicial e final de um sistema fornece indicações que nos permitem reconhecer a ocorrência de transformações neste sistema."

Dentre as diversas atividades propostas aos educandos nos anos de 2006 e 2007, podem-se citar, além daquelas que procuram resgatar, as concepções espontâneas a respeito de transformação, por meio da construção de Tabelas Individuais e Coletivas, alguns procedimentos experimentais, análises dos dados coletados nesses procedimentos, as conclusões a que os alunos chegaram após as análises, exercícios para resolução de problemas fixando as idéias propostas e discussões gerais com a classe, tendo a professora como mediadora, a fim de ordenar as idéias apresentadas pelos alunos.

Todas as atividades desenvolvidas envolveram os alunos em novos conceitos ainda não assimilados como, por exemplo, sistemas em transformação e suas evidências, reações químicas, processos físicos.

A análise das atividades selecionadas como fonte de dados foi feita conforme proposto por VIGOTSKI (2005), no que diz respeito às etapas de formação de conceitos, de acordo com as categorias e subcategorias apresentadas ${ }^{45}$ nas Figuras 4.7 e 4.8.

$\mathrm{Na}$ Figura 5.1, apresentamos conceitos que podem ser ressignificados pelos educandos, a partir do estudo das transformações dos materiais, partindo-se de um conceito mais inclusivo para um menos inclusivo, ou seja, partindo de um conceito mais abrangente (transformação) para outros mais específicos, como o conceito de transformação química, que leva à construção de conceitos associados, como os de substância e mistura.

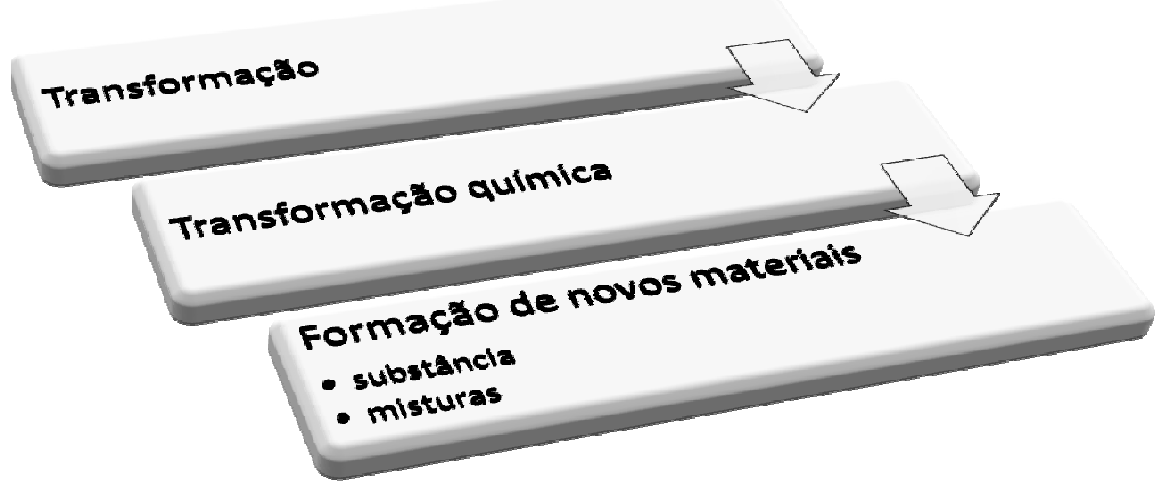

Figura 5.1. Conceitos a serem ressignificados na estrutura cognitiva dos educandos, partindo de um conceito mais abrangente para um conceito mais específico.

\footnotetext{
${ }^{45}$ As definições das categorias e subcategorias utilizadas para análise estão definidas no capítulo 4 Metodologia - desta Dissertação.
} 
O desenvolvimento de conceitos químicos possibilita a prática de uma ação reflexiva na busca pelo conhecimento, quando os conflitos gerados na estrutura cognitiva estão contextualizados com a realidade dos educandos. Conseqüentemente, o aprendizado advindo de atividades que requerem a constante ressignificação de conceitos, a partir dos conhecimentos prévios dos alunos, favorece a ampliação da linguagem utilizada para a construção significativa do saber.

Assim, as quatro atividades analisadas conforme se segue nos darão indícios se houve ou não desenvolvimento na estrutura cognitiva dos educandos, conforme a definição do conceito referenciado.

\subsubsection{Análise da primeira e segunda atividades}

A primeira atividade proposta no PROQUIM - "Relacione, individualmente, dez transformações e justifique como você pôde reconhecê-las" - tinha como objetivo fazer com que os alunos resgatassem suas percepções de mudanças presentes em seu dia-a-dia. Após a construção da Tabela Individual ${ }^{46}$, discutiu-se com os alunos sobre algumas evocações mencionadas nas Tabelas Individuais, com o objetivo de fazê-los perceber que as transformações são identificáveis pelas diferenças de características antes e após o processo.

A quantidade de evocações expressas pelos alunos de $1^{\text {a }}$ série do Ensino Médio para construção das Tabelas Individuais de transformações, nos anos de 2006 e 2007, está listada na Tabela 5.1.

Tabela 5.1 - Quantidade de evocações construídas individualmente nos anos de 2006 e 2007.

\begin{tabular}{lccc}
\hline Período letivo & $\mathbf{2 0 0 6}$ & $\mathbf{2 0 0 7}$ & Total \\
\hline Número de alunos & 35 & 83 & 118 \\
\hline Evocações & 34 & 80 & 114 \\
\hline
\end{tabular}

O total de evocações resultou em número de 114, para um total de 118 alunos participantes. Estes números representaram 30\% de evocações e de participantes para o ano de 2006 e $70 \%$ de evocações e participantes para o ano de 2007. A Tabela Individual

${ }^{46}$ Tabelas constantes dos anexos C1 e C2, nas páginas 199 e 201, respectivamente. 
do ano de $2006^{47}$ totaliza 35 participantes e 34 diferentes evocações; 27 evocações foram feitas pelos alunos da Turma A e 17 pelos alunos da Turma B. Já a Tabela Individual de $2007^{48}$ totaliza 83 alunos participantes e 80 diferentes evocações, sendo que 50 foram feitas pelos alunos da Turma A, 45 pela Turma B e 38 pela Turma C. Algumas evocações foram semelhantes para as duas turmas participantes de 2006 e para as três turmas participantes do ano de 2007.

Durante a construção individual dessas Tabelas a professora-pesquisadora percebeu que os educandos mostravam-se curiosos em saber o que os colegas estavam escrevendo. Acreditamos que este fato deve ter facilitado a interação entre os alunos desde a primeira atividade proposta em nossos estudos, como também evidencia porque alguns sistemas mencionados nas Tabelas individuais eram iguais para alguns alunos.

Após os alunos terem terminado a construção de suas Tabelas Individuais a professora-pesquisadora iniciou uma discussão com todo o grupo, durante a aula, solicitando que sugerissem dez sistemas para compor o quadro geral da classe.

A mediação exercida pela professora-pesquisadora e a socialização de idéias também participada pelos aprendizes, permitiu que conceitos fossem revistos e reelaborados, apresentando maiores informações para a construção das outras Tabelas ${ }^{49}$, que sumariam o quadro geral de cada classe, explicitando, com maior clareza as formas de reconhecimento dos sistemas em transformação.

A Tabela 5.2 apresenta o total das evocações listadas por todas as turmas participantes da pesquisa, para a construção das Tabelas Coletivas de transformações.

Tabela 5.2 - Quantidade de evocações apresentadas coletivamente pelas turmas participantes da pesquisa.

\begin{tabular}{|c|c|c|c|c|c|c|}
\hline Ano letivo & & & & 2007 & & Total \\
\hline Turmas & $1 \mathrm{~A}$ & $1 \mathrm{~B}$ & $1 \mathrm{~A}$ & $1 \mathrm{~B}$ & $1 \mathrm{C}$ & - \\
\hline Evocações & 9 & 10 & 9 & 10 & 10 & 41 \\
\hline$\%$ & 19 & 21 & 19 & 21 & 21 & - \\
\hline Alunos & 17 & 18 & 24 & 32 & 27 & 118 \\
\hline
\end{tabular}

Dos resultados obtidos a partir da construção das Tabelas Coletivas de 2006 e $2007^{50}$ obtiveram-se 16 diferentes evocações feitas pelos alunos do ano de 2006 e 25 diferentes evocações expressas pelos alunos do ano letivo de 2007.

\footnotetext{
47 Tabela constante do anexo C1, na página 199.

48 Tabela constante do anexo C2, na página 201.

${ }^{49}$ Tabelas constantes dos anexos C3 e C4, nas páginas 209 e 210, respectivamente.

${ }^{50}$ Cf. nota 49 deste Capítulo.
} 
Apesar do número de alunos participantes da pesquisa no ano de 2007 ter sido mais significativa que no ano de 2006, a quantidade de evocações diferentes em cada turma foi muito parecida.

Mediante as mensagens apresentadas pelos alunos durante a construção das Tabelas Individuais $^{51}$, pudemos analisar as etapas da formação do conceito de transformação e organizar os dados provenientes desta análise, em Tabelas que apresentam as concepções prévias dos educandos dos anos de 2006 e $2007^{52}$.

As categorias e subcategorias que representam estas etapas estão apresentadas na Tabela 5.3.

Tabela 5.3 - Etapas de formação do conceito de transformação, utilizando sistemas apresentados nas Tabelas Individuais na primeira e segunda atividades.

\begin{tabular}{llll}
\hline \multicolumn{1}{c}{ Categorias } & \multicolumn{1}{c}{ Subcategorias } & \multicolumn{2}{c}{$\begin{array}{c}\text { (\%) } \\
\text { ocorrência/ano }\end{array}$} \\
\cline { 2 - 4 } & & $\mathbf{2 0 0 6}$ & $\mathbf{2 0 0 7}$ \\
\hline \multirow{3}{*}{ Amontoados Sincréticos } & Tentativa e Erro & $29 \%$ & $44 \%$ \\
\cline { 2 - 4 } & Organização do Campo Visual & $44 \%$ & $14 \%$ \\
\cline { 2 - 5 } Pensamento por Complexos & TOTAL & $73 \%$ & $58 \%$ \\
\hline \multirow{2}{*}{ Pensamento Conceitual } & Pseudoconceito & $15 \%$ & $26 \%$ \\
\cline { 2 - 5 } & TOTAL & $15 \%$ & $26 \%$ \\
\hline Outros & Conceitos Potenciais & --- & $2,0 \%$ \\
\cline { 2 - 5 } & Conceitos Abstratos & --- & $2,5 \%$ \\
\cline { 2 - 5 } & TOTAL & $12 \%$ & $13,5 \%$ \\
\hline & & $100 \%$ & $100 \%$ \\
\hline
\end{tabular}

A primeira categoria, denominada "Amontoados Sincréticos", agrupa a maioria das justificativas de reconhecimento de transformação dos materiais, expressas pelos educandos, sendo $73 \%$ para o ano de 2006 e $58 \%$ para o ano de 2007 . Entre os educandos do ano de 2006, 44\% das explicações para justificar o reconhecimento de um processo em transformação são classificáveis na subcategoria "Organização do Campo Visual”. Já para os educandos do ano de 2007, a maioria das justificativas de reconhecimento de um sistema em transformação está agrupada na subcategoria "Tentativa e Erro" (44\%).

Na segunda categoria - "Pensamento por complexos" - observamos que $26 \%$ das explicações dos alunos de 2007 e 15\% dos alunos de 2006, significam o conceito de transformação conforme as características relacionáveis para a subcategoria "Pseudoconceito". Por fim, apenas 2,5\% das justificativas dos alunos de 2007 e nenhuma

${ }^{51}$ Cf. nota 46 deste Capítulo

${ }^{52}$ As Tabelas que originaram a Tabela 5.3 constam dos Anexos D1 e D2, nas páginas 212 e 216, respectivamente. 
dos alunos de 2006, estão na fase mais desenvolvida da formação dos conceitos, a categoria "Pensamento Conceitual". $\mathrm{Na}$ categoria "Outros" encontram-se $12 \%$ das justificativas de reconhecimento feitas pelos alunos de 2006 e 13,5\% dos alunos de 2007.

Podemos notar que, inicialmente, os alunos do ano de 2006, em sua maioria recorreram a imagens criadas em suas mentes para descrever os sistemas e justificar o reconhecimento do processo em transformação através da subcategoria "Organização do Campo Visual". Nesta subcategoria, estão agrupadas $44 \%$ das respostas dos alunos que empregaram suas percepções imediatas para justificar suas formas de reconhecimento dos sistemas em transformação.

Por exemplo, quinze justificativas encontradas neste conjunto relacionam o sistema a uma transformação, ou seja, quando os alunos justificam a percepção da mudança com a mensagem: “(...) mudança de cor, cor, fica transparente (...)”, podemos inferir que eles estão dizendo que antes o sistema possuía uma coloração, mas que não está da mesma forma após a transformação. Contudo, esta mensagem não deixa claro se o conceito está construído em sua estrutura cognitiva ou se apenas ele reconheceu a mudança de cor antes e após a transformação. ${ }^{53}$

Ainda neste mesmo conjunto de mensagens classificamos outras dez justificativas: “(...) consistência, muda a consistência, fica duro, crocante, endurecimento, fica murcho, estoura (...)". Estas justificativas, de forma semelhante, descrevem o processo em transformação apenas por aspectos visuais e táteis, ou seja, macroscopicamente. No entanto, não os comparam com os atributos do sistema antes e após a transformação. Os alunos percebem que ocorreu uma alteração em seu estado anterior, mas não manifestam suas observações a respeito das justificativas de transformações nos sistemas sugeridos. ${ }^{54}$

Já para o ano de 2007, 44\%das justificativas dos alunos para o reconhecimento dos sistemas em transformação são feitas por explicações criadas ao acaso, quando os alunos tentam explicar o que ocorre nos sistemas em processo, porém nem sempre conseguindo fazê-lo com êxito, ou seja, seus apontamentos se relacionam aos sistemas, mas, apesar disso, os educandos não reconhecem as características relacionáveis aos estados inicial e final dos processos, ou mesmo à comparação entre eles. Suas justificativas são classificáveis, na maioria, na subcategoria "Tentativa e Erro" ${ }^{\text {. N }}$. Nela encontramos mensagens como, por exemplo:

\footnotetext{
${ }^{53}$ Consultar Anexo D1, na página 212.

${ }^{54}$ Cf. nota 53 deste Capítulo.

${ }^{55}$ Consultar Anexo D2, na página 216.
} 
“(...) Alimentação inadequada, a rejeição do estômago, quando um alimento não cai bem, por comer algo gorduroso e pesado, embrulhamento no estômago ou dor de barriga (...)".

“(...) Ele penetra no óvulo e depois de nove meses nasce o bebê, o homem e a mulher têm relações e conforme o tempo passa a barriga da mulher cresce e nasce um bebê, os elementos se fundem, a barriga grande, ocorre a copulação entre o homem e a mulher, daí o espermatozóide fecunda o óvulo (...)"

“(..) O ser vivo estava parado (...) e se movimenta, se locomove, antes a pessoa era magra, fazendo exercícios físicos, emagrecer e se movimenta se locomove, antes a pessoa era magra, fazendo exercícios físicos, emagrecer, (...)"

Para estes educandos, este Amontoado Sincrético (VIGOTSKI, 2005, p. 75) de informações se insere no início das etapas de formação do conceito de transformação, ou seja, o desenvolvimento de seu pensamento durante a justificativa de reconhecimento da transformação dos sistemas é “(...) uma mera suposição ou tentativa (...)" de explicação dos fatos, que somente será substituída em sua mente quando novas propriedades relacionáveis a estes sistemas encontrarem um significado particular.

Ainda nesta análise, notamos que na segunda categoria ("Pensamento por Complexos") encontram-se $15 \%$ das justificativas de reconhecimento dos processos feitas pelos alunos do ano de 2006 e $26 \%$ dos alunos do ano de 2007, o que nos permite dizer que esse grupo de educandos já estabelece relações entre os sistemas em transformação e conseguem selecionar alguns de seus atributos de reconhecimento. Portanto, já são capazes de fazer generalizações a respeito do signo em construção, ou seja, suas concepções espontâneas emergem de sua estrutura cognitiva apresentando uma linguagem construída a partir de seu contato com o meio social. Por exemplo:

Para o ano de 2006:

Cinco justificativas: “(...) Água fervendo, gelo derretendo, chuva, água no congelador, em ambiente muito frio ela congela, o gelo em ambiente quente derrete(...)";

Duas justificativas: “(...) Combustão, Queimação do combustível (...)”.

Para o ano de 2007:

Oito justificativas: “(...) O alimento estava cru, mas após fritá-lo ele fica mais saboroso e dura mais, coloca para cozinhar duro e sai mole, quando cozinha ele fica mole, quando cozido ele se torna comestível, põe no fogo cru e sai cozida, antes de cozinhá-lo ele está cru, amolece na água quente, depois que põe o óleo ele frita (...)"; 
Cinco justificativas: “(...) Ela cresce se reproduz e morre, ao ela se abrir, se desenvolver, crescer, reproduzir, após um tempo a flor se transforma em fruto, nasce, cresce e morre, era semente e depois de um tempo ela se tornou uma planta, árvore (...)".

Nesta categoria a maioria das justificativas relaciona processos como ferver, derreter, congelar, queimar, cozinhar e fritar às causas factuais, como tempo e temperatura. Em outro grupo de justificativas, encontramos mensagens que relacionam o desenvolvimento de flores e frutos ao tempo. Isto revela que neste estágio os alunos descrevem a causa da transformação como uma conseqüência da ação do tempo ou da temperatura.

Segundo VIGOTSKI (2005), estes alunos estão agrupando os sistemas de acordo com atributos que os unem, em um complexo associativo coerente, porém sem refletir sobre suas relações. Entretanto, podemos concluir que estes atributos Ihes chamam atenção por possuírem alguma característica em comum.

Já na categoria "Pensamento Conceitual" se encontram 2,5\% das respostas dos alunos de 2007, sendo dividida nas subcategorias "Conceitos Potenciais" (2\%) e "Conceitos Abstratos" (0,5\%). Como exemplo para as justificativas classificáveis nesta categoria podese citar: "(...) antes era um pó que se dissolveu na água quente e foi refrigerado, ficando com uma consistência gelatinosa (...)". Aqui podemos observar a referência a um estado anterior do sistema, as condições para que se transformasse e as características distinguidas após a transformação já ocorrida. Na justificativa “(...) que o gás do fogão reage com o oxigênio do ar para produzir o calor que utilizamos para cozinhar (...)", nota-se a menção que estes alunos fazem ao processo de combustão para gerar o calor necessário ao cozimento de algum alimento. Assim, inferimos que a linguagem que o aluno utilizou para justificar o sistema em transformação relaciona-se a uma condição externa para que o material em estudo se modifique.

Ressaltamos que esses alunos encontram semelhanças entre os sistemas em transformação, conseqüentemente, conseguem se utilizar de conhecimentos adquiridos em outros momentos para dar significado ao símbolo em desenvolvimento. Deste modo, quando se referem a uma transformação, sintetizando informações em uma única mensagem, significa dizer que estão unindo atributos, ainda numa linguagem discreta e sem muitas descrições, porém em um nível máximo de semelhança.

Podemos, então, dizer que suas justificativas se enquadram na subcategoria "Conceitos Potenciais", pois estão voltadas para ações relacionáveis a cada sistema. De modo semelhante, em pesquisa realizada por KINALSKI \& ZANON (1997), com educandos de educação básica, a respeito de suas concepções sobre materiais e substâncias, notou-se 
que esses alunos também recorreram a conhecimentos elaborados em outros momentos para relatarem suas observações nas atividades propostas.

Outra importante mensagem encontrada nas atividades individuais destes alunos do ano de 2007 foi: “(...) a luz do sol é transformada em energia, por exemplo, a luz do sol passa por um tipo de material, similar ao vidro, podendo então aquecer a água, um cômodo, etc (...)". Neste caso, os alunos se utilizam de exemplos observados no dia-a-dia e procuram justificar o reconhecimento de transformação do sistema, através de uma linguagem mais rebuscada, ou seja, procuram explicar o processo que originou a transformação da energia solar em energia térmica, para que a mesma fosse empregada no aquecimento da água e outros ambientes, ou seja, relacionam a transformação e percebem sua aplicação em situações cotidianas. Contudo, compreendemos que este grupo de alunos ainda está construindo o conceito de transformação dos materiais, pois os atributos do conceito em estudo ainda precisam ser mais bem elaborados em sua estrutura cognitiva.

Durante o direcionamento das observações dos alunos acerca dos conceitos apresentados, esperava-se que aspectos macroscópicos dos materiais e suas propriedades físicas fossem identificados com maior facilidade, verificando se os novos conceitos foram devidamente interiorizados, explorando-se a diferenciação da linguagem utilizada ao início e ao fim do desenvolvimento das atividades apresentadas pelo PROQUIM.

Algumas transformações apresentadas pelos aprendizes nos dois períodos letivos se referem a um produto já finalizado (estático) e não à variação do sistema em estudo. Neste caso, percebe-se que os alunos não fazem distinção entre os estados inicial e final dos sistemas, estando suas justificativas de reconhecimento dos processos classificadas, em sua maioria, na categoria "Amontoados Sincréticos", tanto para o ano de 2006 como para o ano de 2007.

Este fato fica evidenciado quando muitos alunos do ano de 2006 e 2007 confundem um processo dinâmico com um sistema estático. Por exemplo, nas evocações 2, 20, 27 e 33 da Tabela Individual de $2006^{56}$, que se referem, respectivamente, a refrigerante e cerveja (48\% dos alunos da $1^{\underline{a}}$ série $\left.A\right)$, unhas ( $6 \%$ dos alunos da $1^{\text {a }}$ série $\left.B\right)$, milho de pipoca $(6 \%$

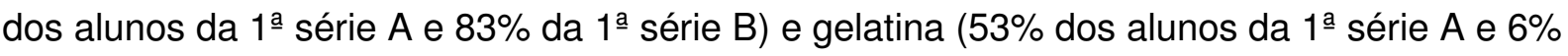
da $1^{\text {a }}$ série $\left.B\right)$.

As justificativas de reconhecimento da transformação desses sistemas não apresentam os aspectos particulares de cada evocação, em suas fases inicial e final, pois

${ }^{56}$ Cf. nota 47 deste capítulo. 
evidenciam, somente, a presença de materiais que o constituem. Citam também os processos de mudança sofridos pelos sistemas, sem mencionar suas peculiaridades.

No caso em que os alunos se referenciam a processos como "fermentação", "crescimento", "estoura" e "endurecimento" podemos inferir que eles reconhecem que os sistemas precisam passar por um procedimento de transformação de suas características iniciais para serem diferenciadas ao final de sua modificação, entretanto, percebemos que ainda não conseguem fazê-lo com clareza. Por exemplo, temos os sistemas apresentados nas Figuras 5.2 a 5.5 .

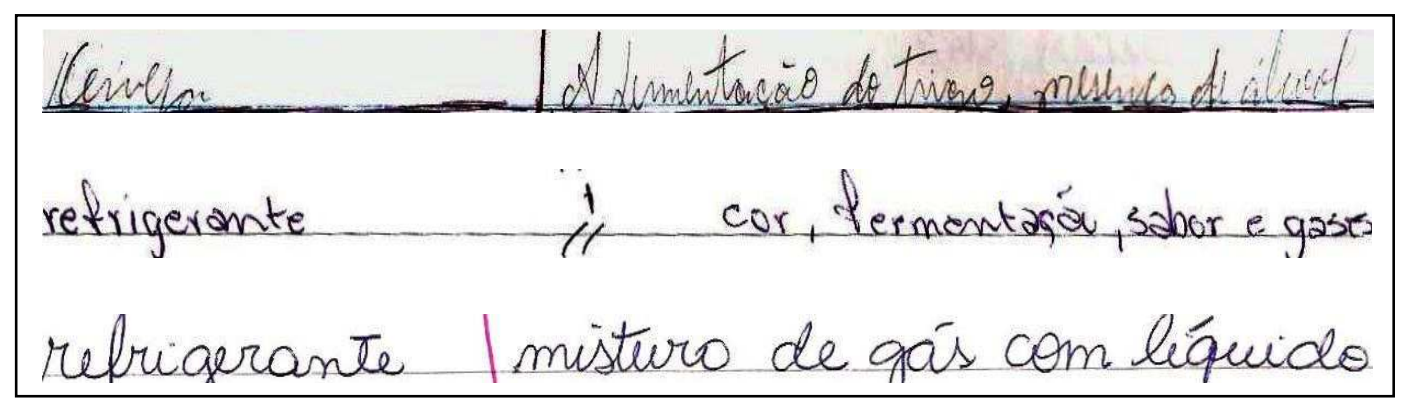

Figura 5.2. Evocações referentes a refrigerante e cerveja ${ }^{57}$

Nas evocações apresentadas na Figura 5.2, observamos justificativas de reconhecimento feitas pelos alunos aos sistemas "refrigerante e cerveja". As explicações dos educandos, para esses sistemas, referem-se a suas percepções no âmbito macroscópico, porém não se nota indicadores de um processo de transformação, pois os educandos mencionam termos como, cor, sabor, gases, perceptíveis pelos sentidos em um momento já finalizado, porém não citam as características desses sistemas antes da transformação.

De forma semelhante estão postas suas observações quando utilizam termos como presença de álcool ou mistura de gás com líquido, para justificar a menção a este sistema, porém, sem conseguir relacioná-lo a dinâmica de sua transformação. Portanto, no caso dos sistemas apresentados na Figura 5.2, podemos dizer que as concepções destes educandos para sistemas em transformação são agrupáveis na categoria Amontoados Sincréticos, onde as mensagens estão ali dispostas por serem relacionáveis por um aglomerado de informações desordenadas, perceptíveis por suas características finais e dos elementos que supostamente cada sistema contém.

No sistema apresentado na Figura 5.3, pode-se observar que este grupo de alunos identifica que o crescimento da unha demonstra sua modificação, mesmo sem mencionar

57 Tabelas individuais enfatizando as evocações referentes a refrigerante e cerveja, constam do anexo $\mathrm{E} 1$, nas página 226-228. 
características antes do crescimento ou o que levou a sua transformação. Deste modo, pode-se dizer que estes alunos estão admitindo que antes a unha era pequena, mas agora ela está maior.

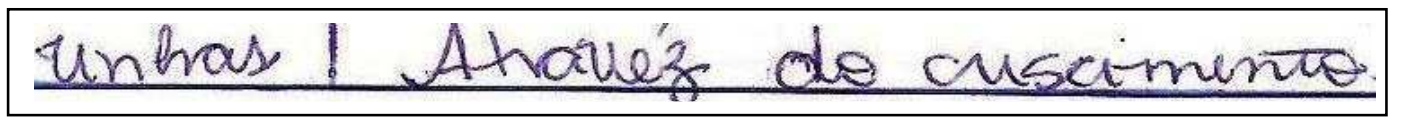

Figura 5.3. Evocação referente a unhas ${ }^{58}$

Contudo, apesar da justificativa de reconhecimento "através do crescimento", estar classificadas na categoria Pensamento por Complexos, é necessário enfatizar que, para o educando, não ficou claro o processo de transformação para este sistema, sendo que o contrário somente poderíamos afirmar se sua argumentação para o referido processo estivesse mais bem especificada, apresentando os atributos relacionáveis ao sistema.

As evocações apresentadas na Figura 5.4, referentes a milho de pipoca, descrevem em suas justificativas de transformação algumas observações feitas pelos educandos e relacionáveis a um processo dinâmico, porém sem apresentar as características do sistema antes da transformação. Termos como, muda de cor, fica macio e crocante, estoura, remetem a uma transformação, mas sem identificar suas características primeiras. Assim, apenas citar o processo "milho de pipoca" sem caracterizar suas características antes da transformação, indica que estes alunos não se apropriaram do conceito de transformação dos materiais.

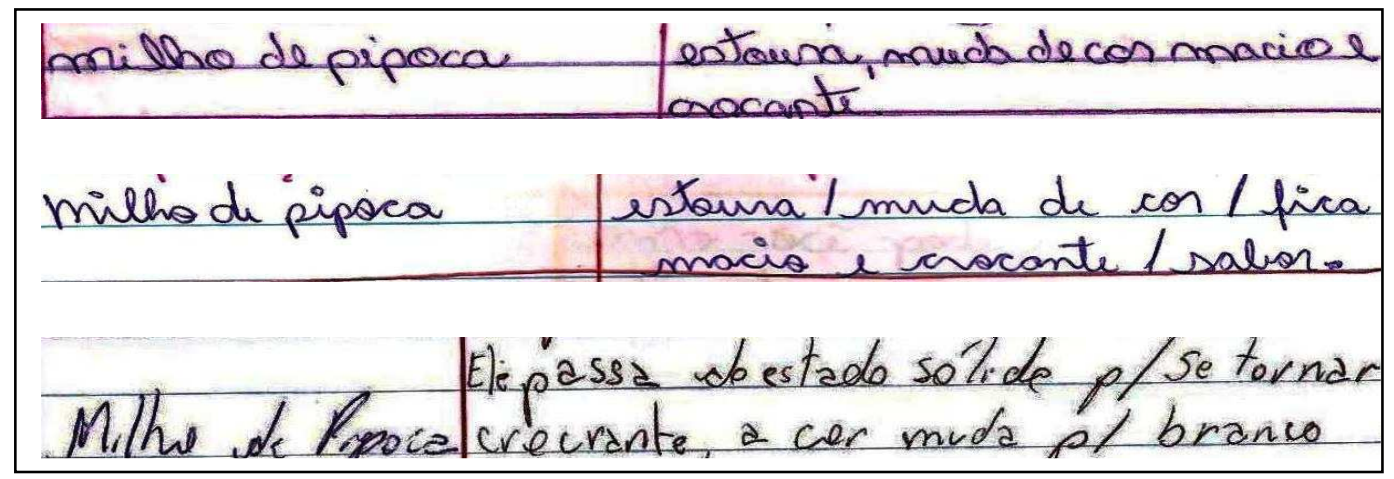

Figura 5.4. Evocações referentes a milho de pipoca ${ }^{59}$

No caso das evocações referentes a milho de pipoca, apesar dos alunos mencionarem o processo "estoura" e perceberem que houve mudança de cor, o conjunto de suas justificativas nos remetem a explicações criadas ao acaso. Assim, essas justificativas perceptíveis macroscopicamente, porém sem apresentar as características do sistema

\footnotetext{
${ }^{58}$ Tabela individual enfatizando a evocação referente a unhas, consta do anexo E2, na página 229.

${ }^{59}$ Tabelas individuais enfatizando as evocações referentes a milho de pipoca constam do anexo E3, nas páginas 230-232.
} 
antes e após a transformação também são classificáveis na categoria Amontoados Sincréticos.

De modo semelhante às explanações feitas anteriormente, o grupo de alunos que mencionou o sistema apresentado na Figura 5.5, "gelatina", não possui os atributos concernente a um processo em transformação, pois não apresenta características próprias do sistema antes e após sua transformação, sendo este sistema e o conjunto de suas justificativas também classificáveis na categoria Amontoados Sincréticos.

Este fato nos mostra que estes alunos fazem referências a aspectos perceptíveis macroscopicamente, porém sem identificar sua modificação ao longo da transformação. Eles apenas falam de observações feitas após o produto já estar finalizado, ou seja, percebem mudança na consistência do produto, citando a percepção da mudança pelo gosto, cor e endurecimento. Como em toda afirmação cabe uma negação, quando os alunos citam as justificativas de reconhecimento endurecimento, consistência, cor e gosto, estão admitindo que o gosto, a cor e a consistência se modificaram.

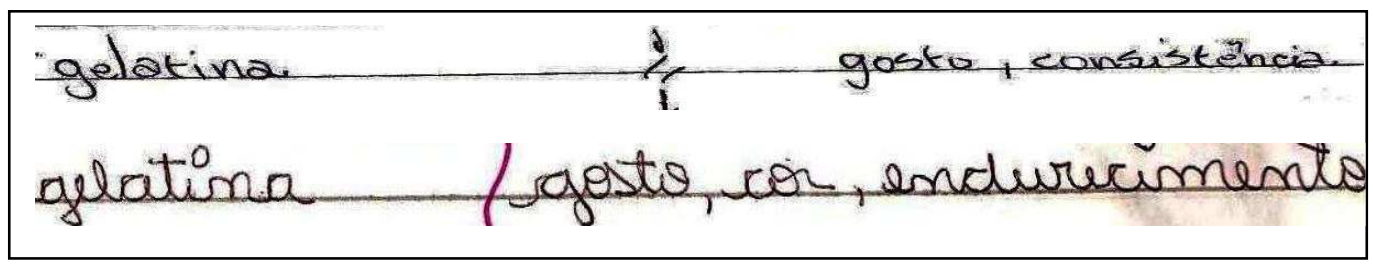

Figura 5.5. Evocações referentes a gelatina ${ }^{60}$

Em 2007, na Tabela Individual ${ }^{61}$, fato semelhante se caracteriza quando encontramos algumas evocações que também se referem a um produto já finalizado, como, por exemplo, a evocação 11 (fezes/urina, citado por 2\% dos alunos do 1A) e a evocação 55 (ar, mencionado por $4 \%$ dos alunos do $1 \mathrm{~B}$ ), ambas com suas justificativas de reconhecimento classificáveis na subcategoria Pseudoconceito e a evocação 17 (leite/queijo, mencionado por $4 \%$ dos alunos do $1 \mathrm{C}$ ), justificável por explicações classificadas na subcategoria Tentativa e Erro.

Confrontado ao mencionado pelos alunos de 2006, somente no caso da evocação 2 (refrigerante e cerveja) da Tabela Individual ${ }^{62}$, os alunos mencionam os produtos presentes na mistura e superficialmente falam de algumas características, sem reconhecê-las por um processo de mudança ou por ações e conseqüências ocorridas na transformação. Como no

60 Tabelas individuais evidenciando as evocações referentes a gelatina constam do anexo E4, nas páginas 233-234.

${ }^{61}$ Cf. nota 48 deste capítulo.

${ }^{62}$ Cf. nota 47 deste capítulo. 
caso da evocação 20, também da Tabela Individual de 2006, em que se reconhece a transformação pelo crescimento das unhas.

Também podemos perceber que, no caso da evocação 55 (ar - Figura 5.6) da Tabela Individual de 2007, quando os alunos se referem ao reconhecimento da transformação utilizando a expressão “(...) está poluído (...) agora é muito mais poluído (...)", deduzimos que anteriormente ele o admitia como puro e limpo, portanto, provavelmente ele está reconhecendo os atributos do processo antes e após sua transformação.

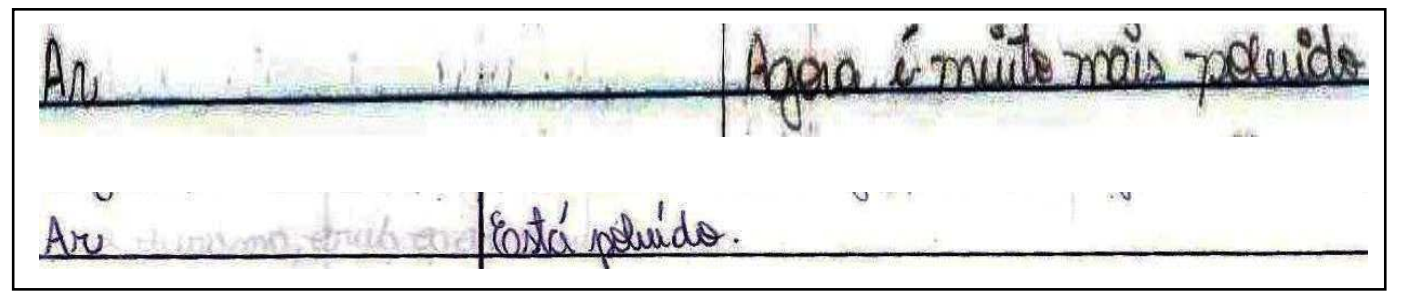

Figura 5.6. Evocações referentes a ar. $^{63}$

No caso dos sistemas apresentados nas Figuras 5.6, 5.7 e 5.9, apesar dos alunos descrevê-los já finalizados, sem delinear as etapas de sua transformação, podemos concluir, nestes casos, que os alunos se remetem a conseqüências dos processos. Deste modo, eles justificam o reconhecimento das transformações explicando que a finalização da transformação só ocorrerá mediante as ações exercidas inicialmente pelos sujeitos causadores da transformação.

Por exemplo, nas expressões apresentadas na Figura 5.8, se “(...) o leite ficar fora da geladeira ele coalha e fica azedo (...)" ou na Figura 5.7, a formação de fezes e urina depende do não aproveitamento de alimento e bebidas pelo organismo, daí “(...) o que não serve sai (...)", observa-se que os alunos imprimiram uma relação causal pela ação ou não do sujeito causador do sistema em transformação.

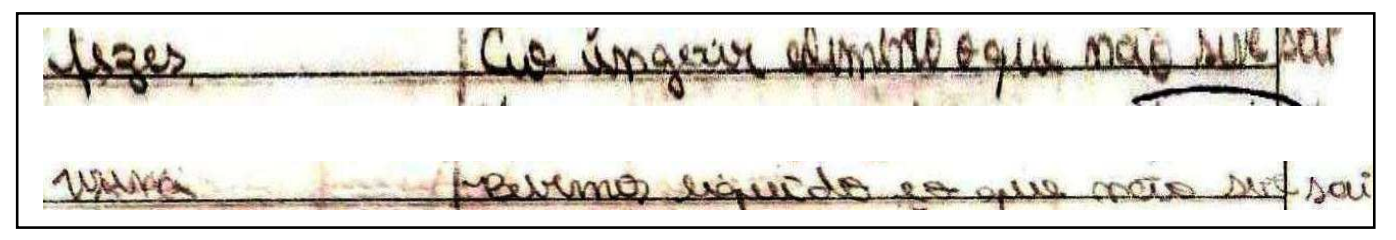

Figura 5.7. Evocações referentes a fezes e urina ${ }^{64}$

No caso dos sistemas apresentados na Figura 5.8, os alunos relacionam o fato do leite fica fora da geladeira com "azedar e coalhar", porém como não expressam o motivo pelo

\footnotetext{
${ }^{63}$ Tabelas individuais enfatizando as evocações referentes a ar constam do anexo E5, na página 235.

${ }^{64}$ Tabelas individuais enfatizando as evocações referentes a fezes e urina constam do anexo E6, na página 236.
} 
qual este fato ocorre, com também não falam de características do leite ou do processo de obtenção do queijo, este sistema fica agrupado na categoria "Amontoados Sincréticos".

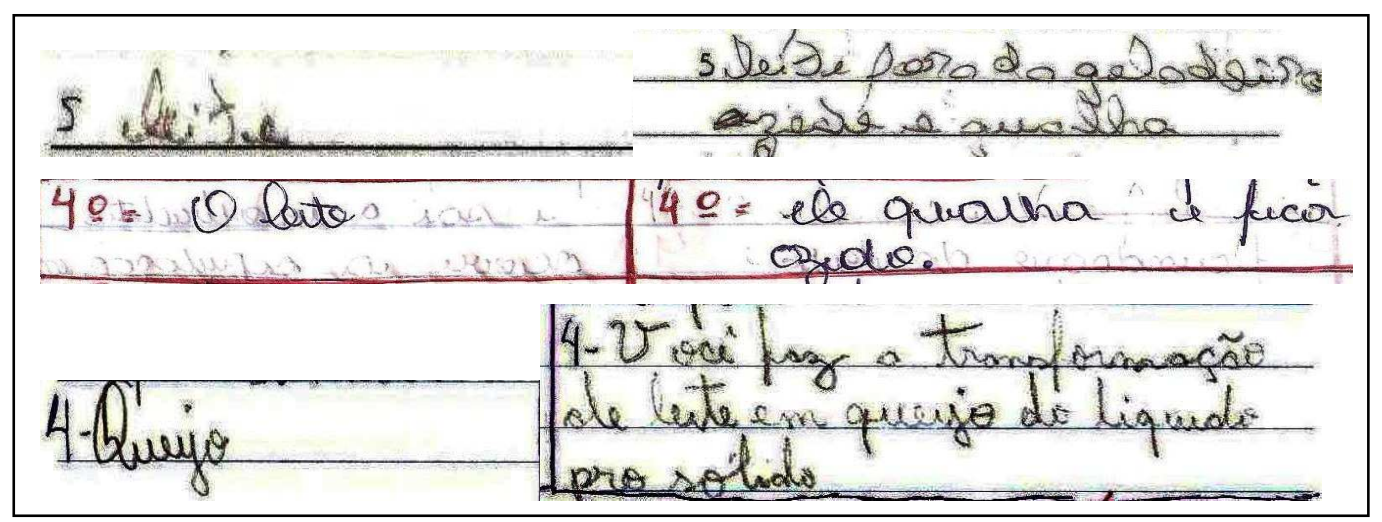

Figura 5.8. Evocações referentes a leite e queijo. ${ }^{65}$

$\mathrm{Na}$ maior parte dos casos, os alunos, acertadamente, considerando o contexto do questionamento, justificam o reconhecimento da transformação pela observação dos aspectos macroscópicos dos sistemas, tais como: cor, sabor, odor, consistência, proporção, estado físico, textura, formato e liberação de gases. Entretanto, a diferenciação entre as etapas da transformação de alguns sistemas não estão claramente evidenciadas, pelos educandos, se tornando necessária a retomada do conteúdo, pela professora, para ampliar os de atributos referentes ao conceito em processo de reelaboração.

Dentre as evocações feitas, por exemplo, a "fermentação de pães e bolos" (Figura 5.10), caracteriza um processo dinâmico por evidenciar uma transformação, como apontaram 59\% dos alunos da turma A e $100 \%$ dos alunos da turma B no ano de $2006^{66}$ e $15 \%$ dos alunos da turma $A, 5 \%$ da turma B e $6 \%$ da turma $C$ no ano de $2007^{67}$; ou mesmo o "desenvolvimento de plantas e sementes" (Figura 5.9), especificado por 76\% dos alunos da turma $A$ e $78 \%$ da turma $B$, do ano de 2006 e $9 \%$ dos alunos da turma $A, 25 \%$ dos alunos da turma B e 8\% dos alunos da turma C do ano de 2007.

No caso das evocações apresentadas na Figura 5.9, estes alunos estabelecem um motivo para a modificação do sistema, por exemplo, quando encontrarmos nas mensagens dos alunos expressões referentes a mudança de cor, mudança de sabor e mudança na consistência, eles estão relacionando essas mudanças ao desenvolvimento das plantas. Ou quando dizem que "(..) a planta nasce, cresce e morre (...)", podemos inferir que parte dos

65 Tabelas individuais evidenciando as evocações referentes a leite e queijo constam do anexo E7, nas páginas 237-239.

${ }^{66}$ Cf. nota 47 deste capítulo.

${ }^{67}$ Cf. nota 48 deste capítulo. 
alunos utilizou-se de expressões que exprimem uma causa para a conseqüência da transformação e que reconhecem as etapas da modificação desses sistemas.

Conseqüentemente, ao organizarem seu campo visual para encontrar características reconhecíveis nos sistemas antes e após o processo ou mesmo ao descrever as etapas de desenvolvimento das plantas, estão identificando atributos do sistema e os estão relacionando a causa de sua transformação. Daí a justificativa de reconhecimento ser classificáveis na categoria Pensamento por Complexos, ou seja, os alunos estão associando atributos para evidenciar características do sistema em estudo.

Nestes exemplos percebemos que alguns alunos estão estabelecendo relações entre os sistemas, distanciando-se das observações feitas ao acaso e aproximando-se do pensamento reflexivo, fundamentando suas justificativas de reconhecimento de mudanças através do que lhes é comum.

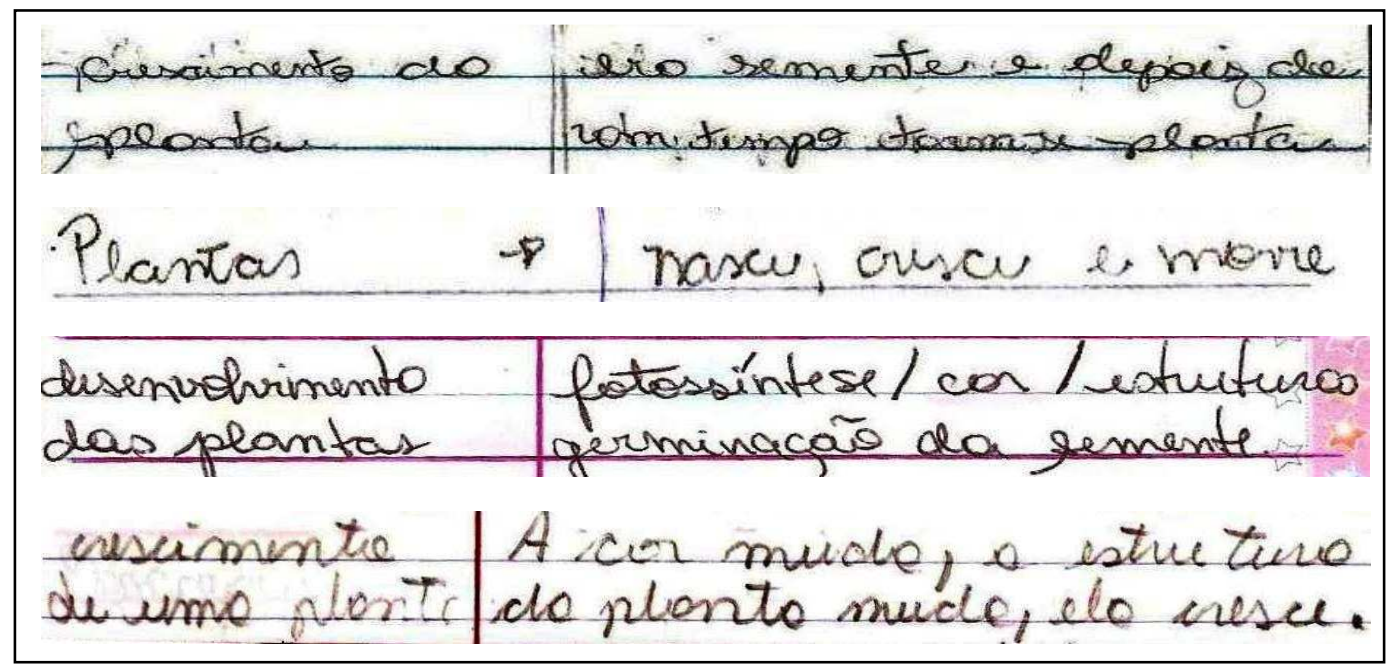

Figura 5.9. Evocações referentes ao processo de desenvolvimento das plantas. ${ }^{68}$

Já na Figura 5.10, encontra-se referência à necessidade de fermento e calor para que o pão ou o bolo cresçam. Em sua maioria, os alunos evidenciam características presentes no processo antes e após a transformação relacionando a mudança na consistência e na cor como predominantes na observação da mudança do sistema. Porém, articulam o crescimento, tanto do pão quanto do bolo, ao calor fornecido pelo aquecimento do forno, como fator determinável para a ocorrência ou não da transformação do sistema.

Apesar de este sistema ser identificado como dinâmico, na categoria "Amontoados Sincréticos", não podemos dizer que os alunos possuem atributos suficientes para ressignificar o conceito de transformação, pois não explicam com clareza a relação existente ${ }^{68}$ Tabelas individuais evidenciando as evocações referentes ao processo de desenvolvimento das plantas constam do anexo E8, nas páginas 240-243. 
entre a temperatura e o fermento para o processo de crescimento do pão e do bolo. Portanto, estes sistemas são agrupáveis nas subcategorias Tentativa e Erro e Organização do Campo Visual, e necessitam de novos atributos relacionáveis ao processo para facilitar a ressignificação do conceito de transformação.

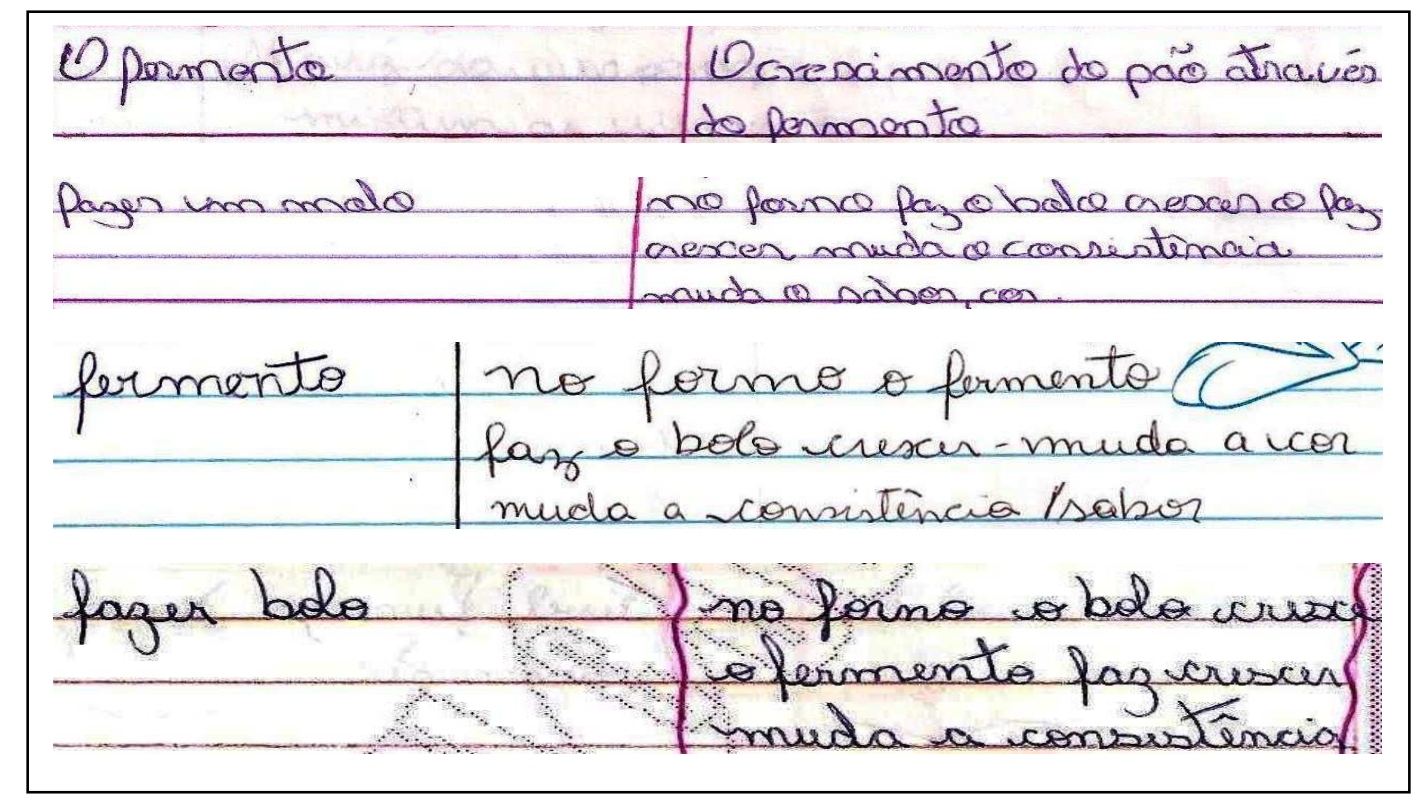

Figura 5.10. Evocações referentes ao processo de fermentação. ${ }^{69}$

Algumas transformações constantes da Tabela Individual de transformações do ano letivo de $2007^{70}$ são indicadas pelos alunos das três turmas sem demonstrar nenhum aspecto que demonstrasse que o processo está em desenvolvimento. Por exemplo, na Figura 5.11, que apresenta a evocação 10, café e leite, água e suco em pó, experimento químico, barro e água, detergente ou sabão em pó, (mencionadas por $3 \%$ dos alunos da $1^{\text {a }}$ série $A, 1 \%$ da $1^{\underline{a}}$ série $B$ e $4 \%$ da $1^{\text {a }}$ série $C$ ), não observamos referências as características dos sistemas antes e após sua transformação. As justificativas de reconhecimento para estes sistemas estão classificadas na categoria Amontoados Sincréticos, porque as mensagens que estão ali contidas não apresentam novos atributos para a construção do conceito de transformação.

Ou mesmo a evocação 38 (lua, sol, dia, mencionada por apenas $1 \%$ dos alunos das três turmas) - Figura 5.12 - com justificativas de reconhecimento dos sistemas em transformação classificáveis na categoria Amontoados Sincréticos, apresenta a transformação de um sistema já sucedida em outro momento (estático), porém nestes

${ }^{69}$ Tabelas individuais enfatizando as evocações referentes ao processo de fermentação constam do anexo E9, nas páginas 244-246.

${ }^{70}$ Cf. nota 48 deste capítulo 
casos as justificativas de reconhecimento apresentam a transformação como um processo dinâmico, propondo uma distinção entre os estados inicial e final dos sistemas.

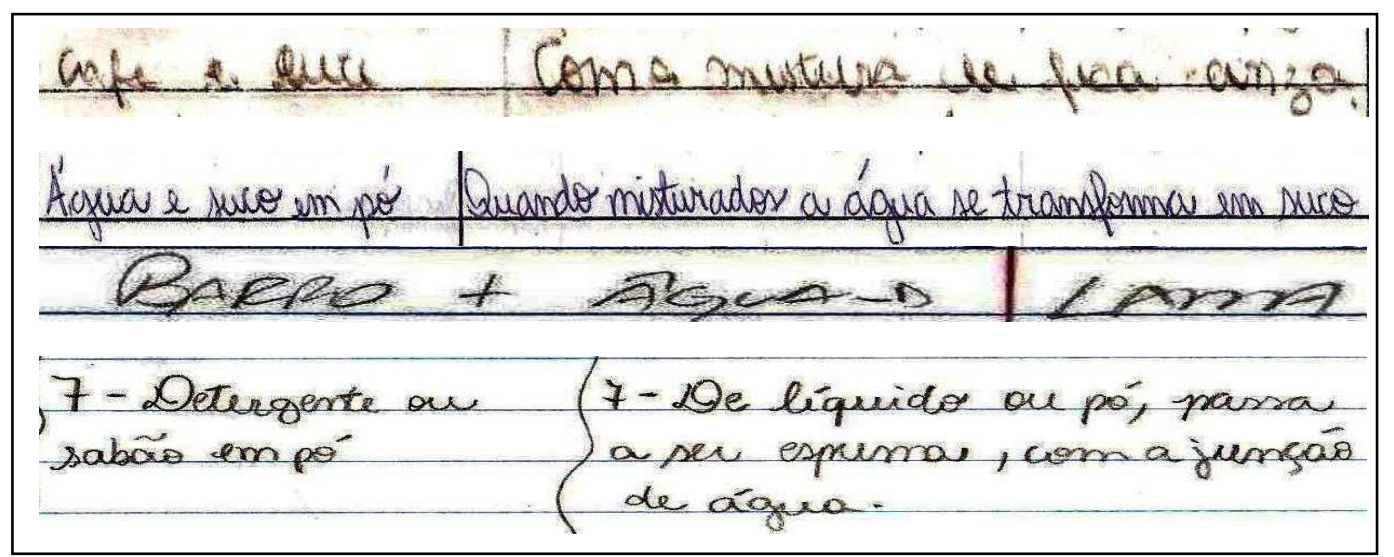

Figura 5.11. Evocações referentes a café e leite, água e suco em pó, barro + água e detergente ou sabão em pó ${ }^{71}$

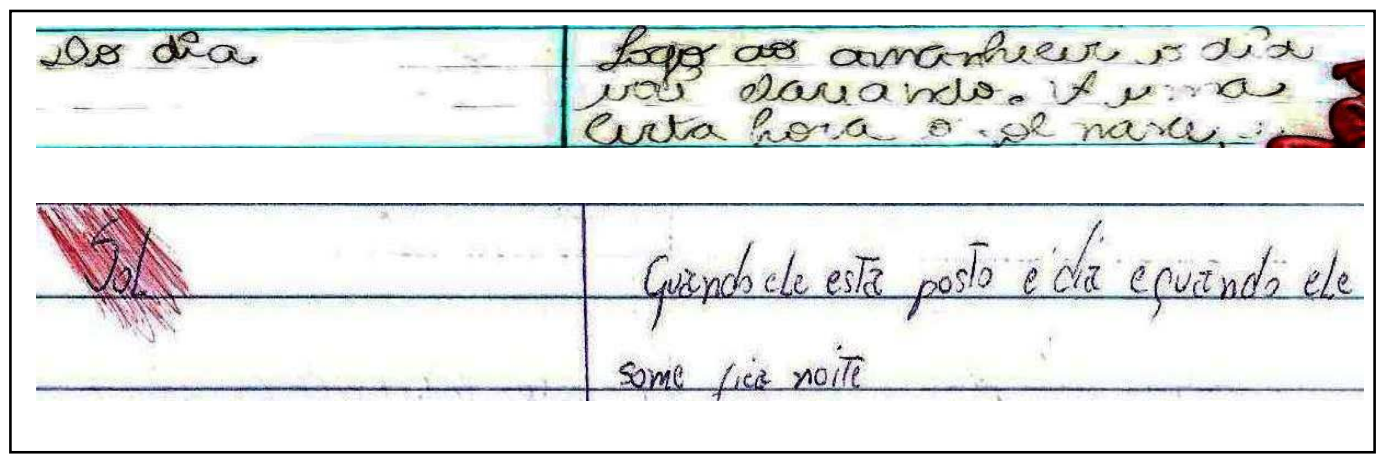

Figura 5.12. Evocações referentes a sol e $\mathrm{dia}^{72}$

No estudo de alguns outros casos, também apresentados pelos alunos das $1^{\text {as }}$ séries do ano de $2007^{73}$, como por exemplo, na Figura 5.13 as evocações 60 (os dentes) e 76 (café), descritos também por uma pequena parcela de alunos, não demonstram nitidamente um processo em mudança, porém, ao analisarmos suas justificativas de reconhecimento percebemos que são capazes de atribuir características distinguíveis para os estados inicial e final dos processos. Quando este grupo de educandos reconhece a mudança no sistema "café” se referenciando à interação entre os componentes “(...) pó + água quente (...)", estão indicando que o produto final só irá surgir se os mesmos estiverem em contato. O sistema identificado como "os dentes" apresenta como justificativa de transformação uma causa para a alteração, ou seja, quando os alunos se referem a ação de comer como implicação para os dentes estarem sujos, estão se referindo a observações que fazem para a nova

71 Tabelas individuais evidenciando as evocações referentes a café e leite, água e suco em pó, barro + água e detergente ou sabão em pó constam do anexo E10 nas páginas 247-248. 72 Tabelas individuais focando as evocações referentes a sol e dia constam do anexo E11, nas páginas 249-250.

${ }^{73}$ Cf. nota 48 deste capítulo 
aparência dos dentes, sendo este aspecto observável macroscopicamente para diferenciálos de sua condição inicial.

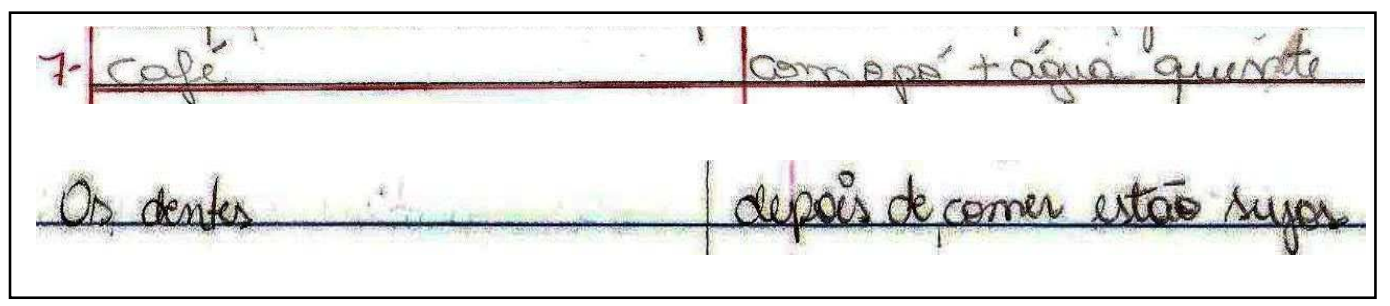

Figura 5.13. Evocações referentes a dentes e café ${ }^{74}$

Após a construção das Tabelas Individuais, discutiu-se em conjunto com os alunos, objetivando a interiorização de que “(...) um processo de transformação de materiais é dinâmico e que suas características devem ser evidenciadas antes e após o procedimento de transformação (...)", para posterior construção de Tabelas Coletivas com o grupo de alunos de cada turma. Essa discussão teve por objetivo a socialização das idéias prévias, presentes em suas estruturas cognitivas, “(...) considerando-se a participação efetiva do estudante no diálogo mediador da construção do conhecimento (...)" (BRASIL, 1999, p. 241).

A partir dessa discussão podemos observar, comparativamente, as justificativas de reconhecimento dos processos em transformação feitas pelos educandos do ano de 2006 , na Tabela Individual e Coletiva ${ }^{75}$. A Tabela 5.4 nos mostra que, apesar da discussão feita entre este grupo de alunos e a professora, a ressignificação do conceito de transformação dos materiais ainda precisa de novos atributos e maiores discussões para se tornar significativo.

Deve-se destacar que, para a construção das Tabelas Coletivas de transformações dos sistemas e suas justificativas de reconhecimento, os alunos ainda não haviam construído o conceito de transformação e os critérios que levam ao seu reconhecimento, sendo que o mesmo estava sendo construído coletivamente, naquele momento.

Durante o processo de socialização das evocações, feitas após a construção das Tabelas Individuais e suas justificativas de reconhecimento, é fundamental “(...) valorizar os saberes prévios dos alunos e seus saberes cotidianos (...)" (LOPES, 2002, p. 392), pois é a partir do que ele já conhece que será capaz de relacionar os saberes escolares às questões concretas da vida diária.

Nessa articulação de saberes construídos no ambiente escolar com o cotidiano é importante o reconhecimento e utilização de novas estratégias e a reelaboração de

${ }^{74}$ Tabelas individuais enfatizando as evocações referentes a dentes e café constam do anexo E12, na página 251.

${ }^{75}$ Cf. notas 53 e 55 deste Capítulo. 
conceitos por meio de ações colaborativas, destacando o conhecimento que o aluno traz consigo para o ambiente escolarizado, sendo que essa prática favorece o desenvolvimento do pensamento reflexivo, necessário à construção do conhecimento científico (JUNIOR, 2008; PELIZZARI et al., 2002; ULLER, 2006; VEIGA \& WEIDUSCHAT, 2004).

Tabela 5.4 - Comparação entre os dados coletados nas Tabelas Individual e Coletiva dos alunos do ano de 2006.

\begin{tabular}{|c|c|c|c|}
\hline \multirow{2}{*}{ Categorias } & \multirow{2}{*}{ Subcategorias } & \multicolumn{2}{|c|}{$\begin{array}{c}(\%) \text { de } \\
\text { ocorrência/2006 }\end{array}$} \\
\hline & & $\begin{array}{l}\text { Tabela } \\
\text { Individual }\end{array}$ & $\begin{array}{l}\text { Tabela } \\
\text { Coletiva }\end{array}$ \\
\hline \multirow{3}{*}{ Amontoados Sincréticos } & Tentativa e Erro & $29 \%$ & $46 \%$ \\
\hline & Organização do Campo Visual & $44 \%$ & $29 \%$ \\
\hline & TOTAL & $73 \%$ & $75 \%$ \\
\hline \multirow{2}{*}{ Pensamento por Complexos } & Pseudoconceito & $15 \%$ & $15 \%$ \\
\hline & TOTAL & $15 \%$ & $15 \%$ \\
\hline \multirow{3}{*}{ Pensamento Conceitual } & Conceitos Potenciais & -.- & $-\ldots$ \\
\hline & Conceitos Abstratos & --- & --- \\
\hline & TOTAL & --- & --- \\
\hline \multicolumn{2}{|l|}{ Outros } & $12 \%$ & $10 \%$ \\
\hline \multicolumn{2}{|c|}{ TOTAL } & $100 \%$ & $100 \%$ \\
\hline
\end{tabular}

Da análise das informações contidas na Tabela 5.4 podemos notar que a maioria das justificativas de reconhecimento dos processos, feitas pelos educandos de 2006, estão classificadas na categoria Amontoados Sincréticos (73\% na Tabela Individual e $75 \%$ na Tabela Coletiva).

A diferença existente entre as classificações das mensagens contidas nas duas Tabelas é que as justificativas de reconhecimento dos processos em transformações, contidos na Tabela Individual foram agrupadas, na maioria, na subcategoria Organização do Campo Visual e na Tabela Coletiva na subcategoria Tentativa e Erro. Nas categorias Pensamento por Complexos e Outros, praticamente não houve alteração. Desta forma, podemos inferir que a discussão realizada entre a professora-pesquisadora e o grupo de educandos do ano letivo de 2006 não foi suficiente para ampliar os atributos do conceito de transformação. Entretanto, pode-se notar que após a discussão os educandos estão tentando apresentar melhores argumentos em suas justificativas de reconhecimento, que anteriormente era feita, em grande parte, apenas com mensagens observadas pelo campo visual do reconhecimento, sem procurar atribuir-Ihes mais características.

Ao compararmos algumas evocações existentes nas Tabelas construídas Individual e Coletivamente, percebemos que os alunos se referem à mesma transformação de forma mais clara e objetiva nesta última, descrevendo o sistema em estudo com informações mais 
abrangentes. Por exemplo, na Tabela Individual do ano de $2006^{76}$, os alunos citam a evocação 11 (decomposição), sem mencionar claramente quais são as características que envolvem o processo, justificando-a apenas em “(...) presença de insetos e animais, odor, mudança de casca (...)", sendo que, para ocorrer mudança de casca, é necessário que o organismo esteja vivo e não em decomposição. Contudo, essa menção não pode ser considerada como um erro que irá prejudicar a formação do conceito de transformação, pois mesmo não pensando objetivamente sobre o processo de decomposição o aluno a percebe como um estado de mudança de um material. Assim, mesmo fora de contexto, a palavra está sendo utilizada de forma generalizada e aplica-se o mesmo critério de identificação de evidências de transformação.

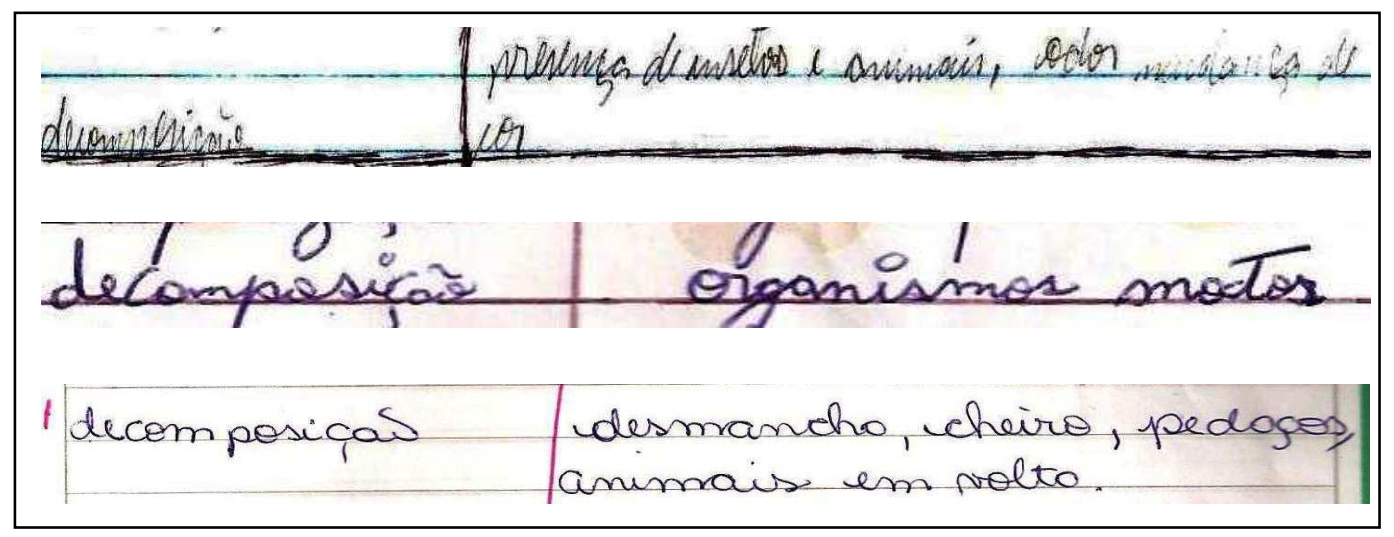

Figura 5.14. Evocações referentes a decomposição ${ }^{77}$

Já na construção da Tabela Coletiva de $2006^{78}$, ao mencionarem a mesma evocação, já o fazem de maneira mais específica, "decomposição de um organismo vivo", e a justificam em "(...) ficar fedido, cheiro, vermes, cor, urubus que ficam ao redor (...)". Daí pode-se inferir que o conceito foi diferenciado por parte dos alunos, por influência dos processos de mediação vivenciados quando da discussão coletiva sobre o conceito. Assim, percebemos que as concepções espontâneas dos alunos foram ressignificadas pela agregação de novos atributos ao conceito de transformação, através da aprendizagem colaborativa envolvendo o grupo de alunos e a professora.

Outra constatação a ser levada em consideração nesta discussão é que parte dos aprendizes se utilizam de seus conhecimentos advindos do cotidiano para se expressarem nas atividades solicitadas no ambiente escolar. Para tanto, eles se aproveitam das experiências relatadas pelos seus pares para construir o próprio conhecimento. Neste contexto, o diálogo mantido em sala de aula é essencial, considerando-se as intervenções

${ }^{76}$ Cf. nota 47 deste capítulo.

77 Tabelas individuais enfatizando as evocações referentes a decomposição constam do anexo E13, nas páginas 252-253.

${ }^{78}$ Tabela constante do anexo C3, na página 209. 
feitas pela professora como mais uma fonte de comunicação entre o objeto de estudo e a aprendizagem construída coletivamente.

Na evocação 9 (cerveja) da Tabela Coletiva do ano de $2006^{79}$, parte dos alunos não mencionam os estados inicial e final deste sistema. De maneira semelhante ao apresentado na Tabela Individual de transformações dos materiais do mesmo período letivo ${ }^{80}$, onde se tem a evocação 2 (refrigerante e cerveja). Este grupo de alunos indica somente os elementos que compõem o sistema e o nome do seu procedimento de obtenção. Portanto, podemos inferir que, neste caso, parte dos educandos não foi capaz de diferenciar os atributos do processo de transformação, sendo que esta evocação fica caracterizada como estática. Percebemos, então, que a discussão entre a professora-pesquisadora e o grupo de alunos, para este caso, não foi suficiente para contribuir à formação do conceito de transformação.

A Tabela 5.5 apresenta dados comparativos entre as evocações construídas individual e coletivamente, pelos educandos do ano de 2007. A partir destas informações podemos notar que diferentemente da Tabela Coletiva construída pelos alunos do ano de 2006, estes alunos já apresentam melhor argumentação quando justificam o reconhecimento dos processos. Este fato se evidencia quando percebemos que a quantidade de justificativas no âmbito da categoria Pensamento por Complexos aumenta de $26 \%$ na Tabela Individual para 48\%, na Tabela Coletiva ${ }^{81}$. Podemos, então, dizer que a mediação exercida pela professora-pesquisadora e pelo grupo de educandos, durante a discussão coletiva sobre o conceito em estudo foi significativa para a ressignificação do conceito de transformação.

Tabela 5.5 - Comparação entre os dados coletados nas Tabelas Individual e Coletiva dos alunos do ano de 2007.

\begin{tabular}{llll}
\hline \multirow{2}{*}{ Categorias } & \multicolumn{1}{c}{ Subcategorias } & \multicolumn{2}{c}{$\begin{array}{c}\text { (\%) de } \\
\text { ocorrência/2007 }\end{array}$} \\
\cline { 2 - 4 } & & $\begin{array}{l}\text { Tabela } \\
\text { Individual }\end{array}$ & $\begin{array}{l}\text { Tabela } \\
\text { Coletiva }\end{array}$ \\
\hline \multirow{3}{*}{ Amontoados Sincréticos } & Tentativa e Erro & $44 \%$ & $23 \%$ \\
\cline { 2 - 4 } & Organização do Campo Visual & $14 \%$ & $13 \%$ \\
\cline { 2 - 4 } & TOTAL & $58 \%$ & $36 \%$ \\
\hline \multirow{2}{*}{ Pensamento por Complexos } & Pseudoconceito & $26 \%$ & $48 \%$ \\
\cline { 2 - 4 } & TOTAL & $26 \%$ & $48 \%$ \\
\hline \multirow{2}{*}{ Pensamento Conceitual } & Conceitos Potenciais & $2,0 \%$ & --- \\
\cline { 2 - 4 } & Conceitos Abstratos & $0,5 \%$ & --- \\
\cline { 2 - 4 } & TOTAL & $2,5 \%$ & --- \\
\hline Outros & & $2,5 \% \%$ & $16 \%$ \\
\hline & TOTAL & $100 \%$ & $100 \%$ \\
\hline
\end{tabular}

\footnotetext{
${ }^{79}$ Cf. nota 78 deste capítulo.

${ }^{80}$ Cf. nota 47 deste capítulo

81 Tabelas constantes do Anexo D2, nas páginas 216-221.
} 
A Tabela Coletiva de transformações ${ }^{82}$, elaborada com os estudantes do ano de 2007, com a mediação da professora-pesquisadora, da mesma maneira que no ano anterior, descreve 25 evocações, sendo que todas elas demonstram um caráter dinâmico. Por exemplo, o primeiro sistema da Tabela Coletiva do ano de 2007, "Esquentar água para preparar o café/ colocar água no congelador, vai virar gelo, formação do gelo", apresenta como justificativas para sua transformação aspectos relacionáveis ao material antes e após a sua alteração.

Neste caso, quando os educandos dizem que perceberam a transformação através da "Presença de vapor; fervendo, antes a água estava numa temperatura ambiente e logo após ficou quente; a água era líquida e ficou sólida", estão demonstrando que identificaram mudanças no material e que a estão relacionando a uma causa, ou seja, a transformação do sistema só ocorreu devido à variação da temperatura.

Da mesma forma, as justificativas de reconhecimento da transformação dos outros sistemas constantes da Tabela Coletiva do ano de 2007 apresentam características próprias às mudanças ocorridas com os materiais em estudo. Daí a maioria das mensagens que expressam as justificativas de reconhecimento dos sistemas em transformação serem classificáveis na categoria Pensamento por Complexos.

Isto nos permite concluir que a discussão promovida sobre os atributos de um sistema em transformação foi significativa para estes alunos, ou seja, o diálogo mantido pelo grupo foi importante para a reelaboração do conceito de transformação, demonstrando que o discurso da professora-pesquisadora não se tornou uma verbalização vazia e influenciou na reelaboração do conceito.

Devemos considerar, então, a partir destas observações, que os alunos, em sua maioria, assimilaram o questionamento feito nestas atividades, individuais e coletivas e que suas concepções, a respeito do conceito transformação, estão em desenvolvimento e irão se estabelecer em suas estruturas cognitivas, por estarem construindo seu conhecimento escolar com base em seu conhecimento prévio.

VIGOTSKI (2005) afirma que a formação dos conceitos não ocorre isoladamente e sim a partir da experiência cotidiana dos educandos, seja no ambiente escolar ou fora dele. Assim, as palavras utilizadas pelos alunos podem expressar suas concepções espontâneas, construídas mediante seus próprios esforços mentais ou por influência de outros, sendo nesse caso chamadas de concepções não-espontâneas, porém que são essenciais para o

${ }^{82}$ Cf. nota 48 deste capítulo 
desenvolvimento do intelecto, por servirem como norteadoras para a gênese de novos conceitos e por se influenciarem mutuamente.

Por conseguinte, para responder as questões que delimitaram esta pesquisa "Situações de aprendizagem realizadas mediante relações colaborativas facilitam a ressignificação do conceito de transformação? É possível reconhecer a modificação na concepção do conceito de transformação para transformação química a partir de atividades existentes no PROQUIM e realizadas colaborativamente?" - analisaremos, também, as respostas dos educandos referentes a outras duas questões, presentes no PROQUIM, e que facilitam o processo de ressignificação do conceito de transformação pelos educandos.

\subsubsection{Análise da terceira atividade}

Apresentamos aos educandos a seguinte situação-problema: "Aqueceu-se um sólido vermelho num tudo de ensaio. Depois de algum tempo de aquecimento detectou-se a liberação de um gás incolor e a formação de um líquido prateado. Pergunta-se: Ocorreu reação química? Qual é a evidência?" Como resposta a esta indagação encontramos as mensagens expressas nas Tabelas organizadas para observação das etapas de formação do conceito de transformação em alunos dos anos letivos de 2006 e $2007^{83}$ e apresentamos esses dados na Tabela 5.6.

Tabela 5.6. Etapas de formação do conceito de transformação para a terceira atividade

\begin{tabular}{llll}
\hline \multicolumn{1}{c}{ Categorias } & \multicolumn{1}{c}{ Subcategorias } & \multicolumn{2}{c}{$\begin{array}{c}\text { (\%) de } \\
\text { ocorrência/ano }\end{array}$} \\
\cline { 2 - 4 } & & $\mathbf{2 0 0 6}$ & $\mathbf{2 0 0 7}$ \\
\hline \multirow{3}{*}{ Amontoados Sincréticos } & Tentativa e Erro & $9 \%$ & $30 \%$ \\
\cline { 2 - 4 } & Organização do Campo Visual & $18 \%$ & $25 \%$ \\
\cline { 2 - 4 } Pensamento por Complexos & TOTAL & $27 \%$ & $55 \%$ \\
\hline \multirow{2}{*}{ Pensamento Conceitual } & Pseudoconceito & $67 \%$ & $45 \%$ \\
\cline { 2 - 4 } & TOTAL & $67 \%$ & $45 \%$ \\
\hline Outros & Conceitos Potenciais & $2 \%$ & --- \\
\hline & Conceitos Abstratos & $2 \%$ & --- \\
\cline { 2 - 4 } & TOTAL & $4 \%$ & --- \\
\hline & & $2 \%$ & --- \\
\hline
\end{tabular}

$\mathrm{Na}$ análise da terceira atividade, selecionada como fonte de dados, pode-se observar uma grande diferença nos estágios de formação do conceito científico transformação, em comparação com a primeira e segunda atividades analisadas, pois os alunos dos anos

${ }^{83}$ Consultar Anexos D3 e D4 nas páginas 222 e 223, respectivamente. 
letivos de 2006 e 2007 estão apresentando, nestas atividades, uma linguagem mais específica para justificar o reconhecimento do sistema em transformação, ou seja, na primeira e segunda atividades suas justificativas de reconhecimento dos sistemas em transformação encontravam-se, em sua maioria, na categoria "Amontoados Sincréticos" (Tabela Individual: 44\% para o ano de 2006 na subcategoria Organização do Campo Visual e 44\% para o ano de 2007 na subcategoria Tentativa e Erro)

Na classificação das mensagens contidas nas Tabelas Coletivas, a maior parte das justificativas encontra-se classificada na subcategoria Tentativa e Erro (46\%, para o ano de 2006) e 48\% na subcategoria Pseudoconceito para o ano de 2007. Já para a terceira atividade a maior parte está caracterizada, para o ano de 2006 (67\%) e para o ano de 2007 (45\%) na subcategoria "Pseudoconceito". Para exemplificar as mensagens encontradas nesta atividade, observamos algumas respostas dos educandos para o reconhecimento de evidências em uma reação química na Figura 5.15.

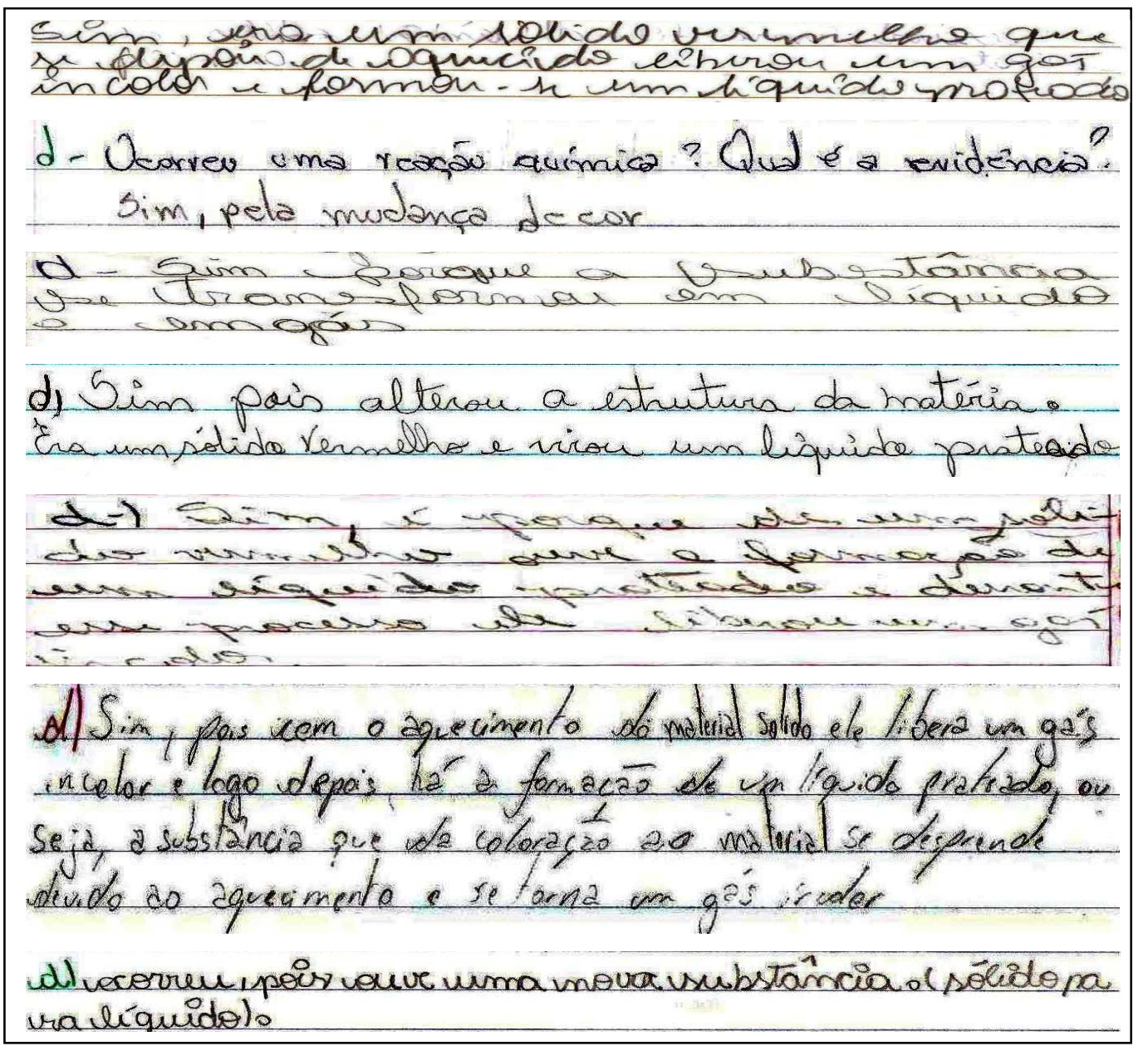

Figura 5.15. Algumas justificativas de reconhecimento da reação química, mencionadas por alunos do ano letivo de $2006^{84}$

${ }^{84}$ Consultar Anexo F1 nas páginas 254-258. 
Na subcategoria "Pseudoconceito" se enquadram 67\% das respostas efetuadas pelos alunos do ano letivo de $2006^{85}$, $18 \%$ são classificáveis na subcategoria "Organização do Campo Visual", 9\% na subcategoria Tentativa e Erro e igualmente classificadas nas categorias "Pensamento Conceitual" e "Outros" (2\%).

A subcategoria "Organização do Campo Visual" apresenta informações fornecidas pelos aprendizes, que utilizaram de conexões perceptuais para chegar à conclusão do reconhecimento da transformação do sistema, ou seja, "(...) se orientaram pela semelhança concreta visível (...)" (VIGOTSKI, 2005, p. 83) para chegar a uma resposta.

Por exemplo, quando dizem que houve reação química porque notam a mudança de cor, estão se orientando por uma observação perceptual para justificar a transformação. Ou quando deduzem que, pelo sistema ter mudado de estado físico e mudado de cor, admitem que ocorreu formação de novo material, e se referenciam a alteração na estrutura da matéria, estão criando explicações de forma ocasional sem poder fazer afirmações no âmbito macroscópico das observações, porque não possuem atributos suficientes para poder afirmar que tal situação tenha de fato ocorrido. Neste caso, as mensagens são classificáveis na subcategoria "Tentativa e Erro".

Quando estes educandos usam termos como “(...) formação de nova substância (...)” ou “(...) alteração na estrutura da matéria (...)", estão se utilizando de conceitos não espontâneos para tentar encontrar uma justificativa para a transformação do sistema. Isso se dá porque estão empregando palavras conhecidas em outros momentos ou que foram utilizadas por outras pessoas mais experientes.

Observamos também que, no exemplo “(...) com o aquecimento do material ele libera um gás incolor e logo depois há a formação de um líquido prateado, ou seja, a substância que dá coloração ao material se desprende devido ao aquecimento e se torna um gás incolor (...)", o aluno relata a mudança de estado físico do material e sua mudança de cor e os relaciona ao fato do material estar sob aquecimento, ou seja, a formação do líquido prateado se sucede à liberação do gás incolor. Entretanto, a afirmação de que há formação de novo material não pode ser entendida como uma concepção do educando, pois as evidências fornecidas durante o relato da questão não fornece informações suficientes para que se possa chegar a esta conclusão, daí a mensagem também ser classificável na subcategoria "Tentativa e Erro".

Exemplificando a linguagem utilizada pelos alunos do ano de 2007, para responder a mesma questão solicitada aos alunos do ano de 2006, resgatamos mensagens contidas em

${ }^{85}$ Consultar Anexo D3 na página 222. 
suas atividades ${ }^{86}$ e as evidenciamos na Figura 5.18. Ressaltamos que $45 \%$ das respostas deste grupo, se enquadram na subcategoria "Pseudoconceito", 30\% na subcategoria "Tentativa e Erro" e 25\% na subcategoria "Organização do Campo Visual".

De forma semelhante ao observado na Tabela 5.5, em que a maioria das repostas está classificada na subcategoria "Pseudoconceito" (48\%), encontramos as mensagens dos educandos nesta terceira atividade. Desta forma, podemos observar nos exemplos contidos na Figura 5.16, que as evidências ressaltadas no processo destacam mudanças no material, como a mudança de cor, perceptível pelo campo visual.

Os alunos relatam em sua resposta que antes o material era sólido e vermelho e que, após a transformação, tornou-se líquido, prateado e liberou gás (Pseudoconceito). Entretanto, não mencionam o fato de a transformação ter ocorrido devido ao aquecimento do sistema. Contudo, ressaltam características do material antes e após a sua transformação, mas suas argumentações para destacar a justificativa da reação química precisam de mais atributos, com o objetivo de que suas respostas possam ser classificáveis na esfera do "(...) pensamento perceptual (...)" (VIGOTSKI, 2005, p. 97).

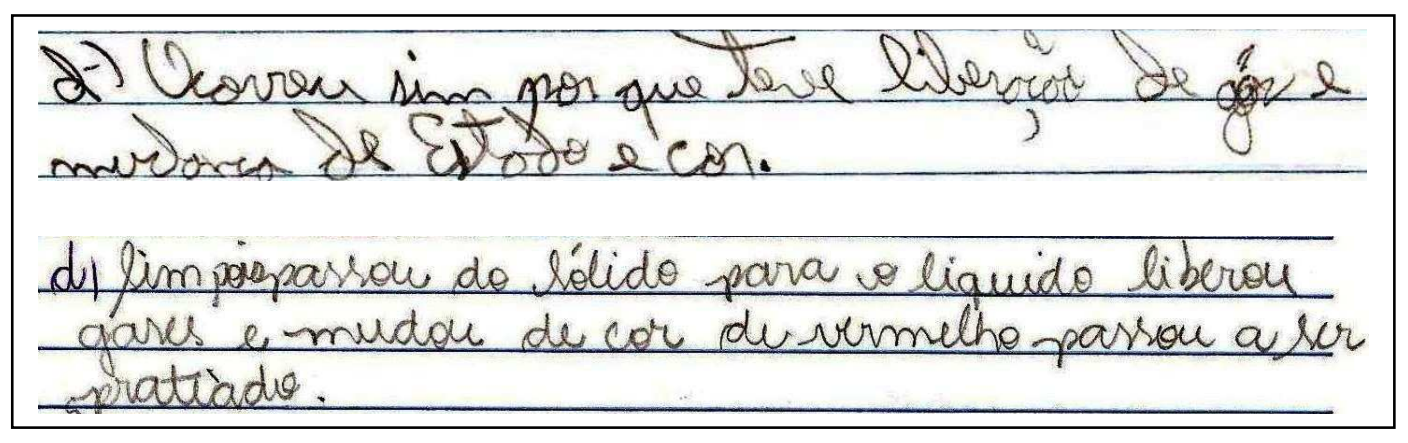

Figura 5.16. Algumas justificativas de reconhecimento da reação química classificadas na subcategoria "Pseudoconceito" ${ }^{87}$

Assim, podemos dizer que as discussões entre a professora-pesquisadora e os educandos não foi suficiente para que os mesmos formassem o conceito de transformação em suas estruturas cognitivas, porém foi importante para a percepção de alguns atributos em evidência. Neste caso, novas discussões que permitam que os educandos expressem suas concepções a respeito do conceito que se pretende ressignificar são importantes para que a professora-pesquisadora possa articular outras atividades que estejam de acordo com as necessidades particulares de cada turma.

\footnotetext{
${ }^{86}$ Consultar Anexo D4 na página 223.

${ }^{87}$ Cf. nota 86 deste capítulo.
} 


\subsubsection{Análise da quarta atividade}

Outra situação-problema proposta aos educandos dos anos de 2006 e 2007, com o objetivo de analisar a formação do conceito de transformação conforme as etapas propostas por VIGOTSKI (2005) foi apresentada com a pergunta: "Quando se aquece a água há liberação de um gás. Está ocorrendo uma reação química? Explique sua resposta".

As respostas dos alunos encontram-se listadas em Tabelas organizadas para observação das etapas de formação do conceito de transformação em alunos dos anos letivos de 2006 e 2007. Conforme a quarta atividade analisada ${ }^{88}$, os dados provenientes dessas mensagens estão presentes na Tabela 5.7.

Tabela 5.7. Etapas de formação do conceito de transformação para a quarta atividade

\begin{tabular}{llll}
\hline \multicolumn{1}{c}{ Categorias } & \multicolumn{1}{c}{ Subcategorias } & \multicolumn{2}{c}{$\begin{array}{c}(\%) \text { de } \\
\text { ocorrência/ano }\end{array}$} \\
\cline { 2 - 4 } & & $\mathbf{2 0 0 6}$ & $\mathbf{2 0 0 7}$ \\
\hline \multirow{3}{*}{ Amontoados Sincréticos } & Tentativa e Erro & $46 \%$ & $78 \%$ \\
\cline { 2 - 4 } & Organização do Campo Visual & --- & $4 \%$ \\
\cline { 2 - 4 } Pensamento por Complexos & TOTAL & $46 \%$ & $82 \%$ \\
\hline \multirow{2}{*}{ Pensamento Conceitual } & Pseudoconceito & $49 \%$ & $18 \%$ \\
\cline { 2 - 4 } & TOTAL & $49 \%$ & $18 \%$ \\
\hline Outros & Conceitos Potenciais & $2 \%$ & --- \\
\hline & Conceitos Abstratos & --- & -- \\
\hline & TOTAL & $2 \%$ & --- \\
\hline
\end{tabular}

Ao analisarmos os dados relativos às respostas dos alunos para a quarta atividade, grande parte destes alunos diz que nota a liberação de um gás durante o processo de aquecimento da água. Suas respostas encontram-se na maioria: 46\% para o ano de 2006 na categoria "Amontoados Sincréticos", 49\% na categoria "Pensamento por Complexos", $2 \%$ na categoria "Pensamento Conceitual" e $3 \%$ na categoria "Outros".

Na categoria "Amontoados Sincréticos" estão 82\% das respostas dos alunos de 2007 , sendo $78 \%$ na subcategoria "Tentativa e Erro" e 4\% na subcategoria "Organização do Campo Visual". Também se encontra $18 \%$ das respostas destes alunos na subcategoria "Pseudoconceito".

Quando estes dois grupos de alunos foram questionados sobre a ocorrência de reação química no processo de aquecimento da água, sugiram expressões como as mostradas nas Figuras 5.17 a 5.19 .

${ }^{88}$ Consultar Anexos D5 e D6 nas páginas 224 e 225, respectivamente. 
$\mathrm{Na}$ categoria, denominada por VIGOTSKI (2005) de "Amontoados Sincréticos", predominam aspectos perceptuais que os educandos utilizam para encontrar um significado para a transformação que está ocorrendo. Contudo, a agregação desordenada (NÉBIAS, 1999) de informações no pensamento dos educandos ainda não permitiu o amadurecimento de novos conceitos.

Podemos notar nas mensagens dos educandos dos dois períodos letivos, quando os alunos do ano de 2007 dizem que “(...) está havendo uma condensação, porque a água está aquecida (...)", relacionam o aquecimento da água a uma mudança, porém, a atribuição do nome condensação ao processo de aquecimento do líquido, demonstra que estão empregando o mesmo signo a processos diferenciados. Portanto, suas observações a respeito do processo de aquecimento da água estão agrupadas na subcategoria "Tentativa e Erro".

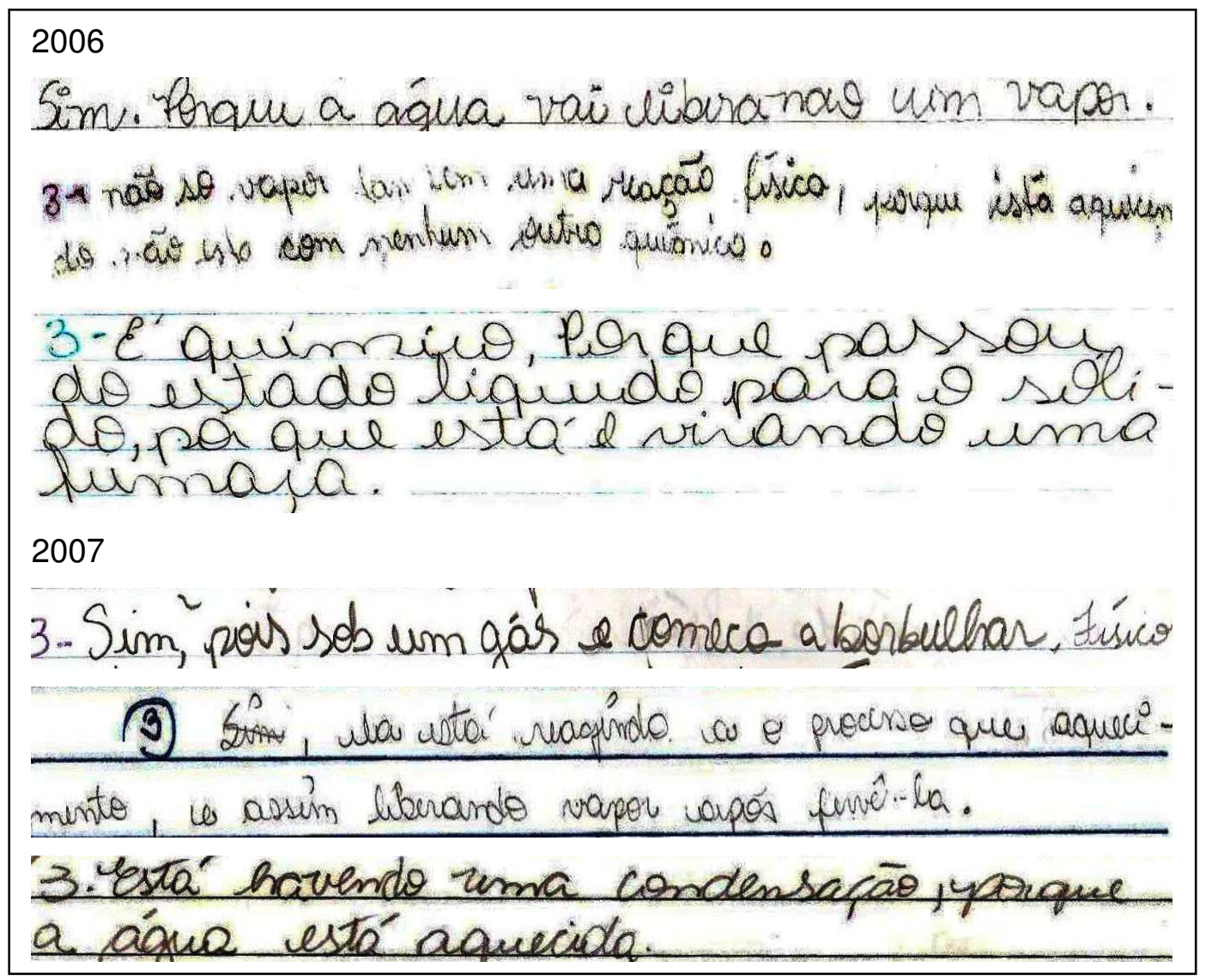

Figura 5.17. Exemplos de respostas classificadas na categoria Amontoados Sincréticos ${ }^{89}$

As expressões “(...) vai liberando um vapor (...)”, “(...) está virando fumaça (...)”, “(..) sobe um gás e começa a borbulhar (...)" ou “(...) liberando vapor após fervê-la (...)", confirmam que estes alunos estão utilizando palavras semelhantes para significar a situação

${ }^{89}$ Consultar Anexo G1 nas páginas 259-272. 
de aquecimento da água. Entretanto, o sentido real da palavra ainda não está desenvolvido, pois ora os alunos afirmam que ocorreu reação química, ora afirmam que está acontecendo a passagem da água do estado líquido para o gasoso. Enfim, observa-se que o conceito de transformação para estes alunos ainda não foi interiorizado.

A Figura 5.18 apresenta expressões dos educandos classificadas, também, na Categoria "Amontoados Sincréticos". Nela estão contidas mensagens classificáveis na subcategoria "Tentativa e Erro", na qual se encontra uma confusão de significados atribuídos a símbolos que estes educandos ainda não possuem atributos suficientes para caracterizá-los.

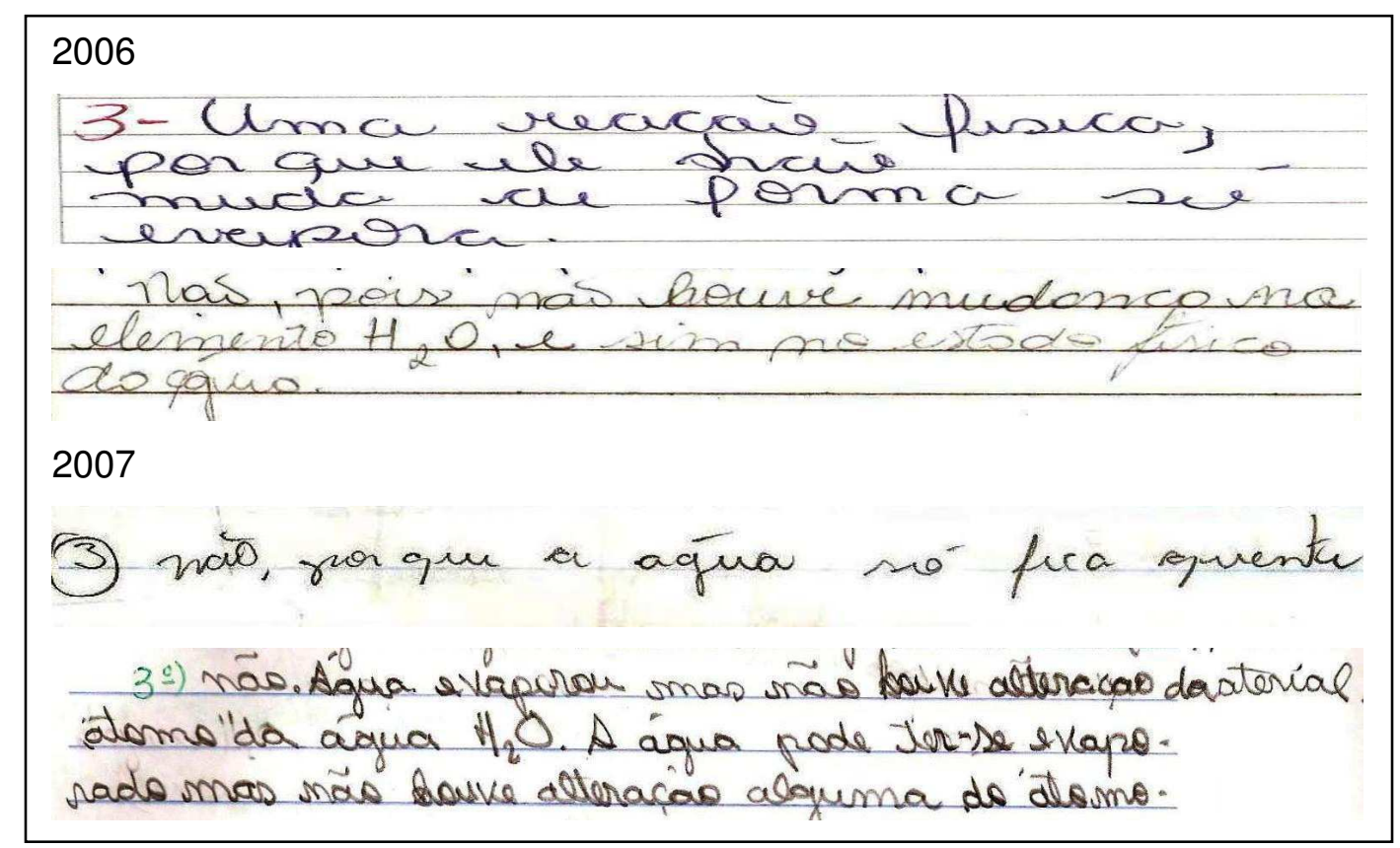

Figura 5.18. Outros exemplos de justificativas classificadas na categoria Amontoados Sincréticos ${ }^{90}$

Nos termos “(...) ele não muda de forma só evapora (...)”, “(...) não houve mudança do elemento $\mathrm{H}_{2} \mathrm{O}\left(\right.$...)" e “(...) não houve alteração do átomo da água $\mathrm{H}_{2} \mathrm{O}($...)", os alunos estão generalizando o significado de palavras como, elemento, átomo e forma para encontrar uma explicação para a transformação sofrida pelo sistema água. Mais exemplos destas mensagens se encontram dispostas na Figura 5.19.

Estes grupos de alunos possuem, em suas estruturas cognitivas, um amontoado de informações que foram se estabelecendo de forma casual e que agora estão sendo empregadas de forma arbitrária, pois estes educandos ainda não têm estes símbolos apreendidos significativamente para utilizá-los como justificativas de reconhecimento para estes processos.

${ }^{90}$ Cf. nota 88 deste capítulo 
Nas justificativas mencionadas por alunos do ano de 2006, “(...) ocorre uma liberação de gás, mas não é uma reação química, pois não alterou a estrutura da matéria, só mudou de estado físico. De líquido para gasoso (...)", podemos observar que não há o reconhecimento do estado inicial e final do sistema e os atributos originados por sua transformação, ou seja, os educandos não tem informações suficientes em sua estrutura cognitiva para afirmar que em decorrência da liberação de gás há mudança de estado físico.

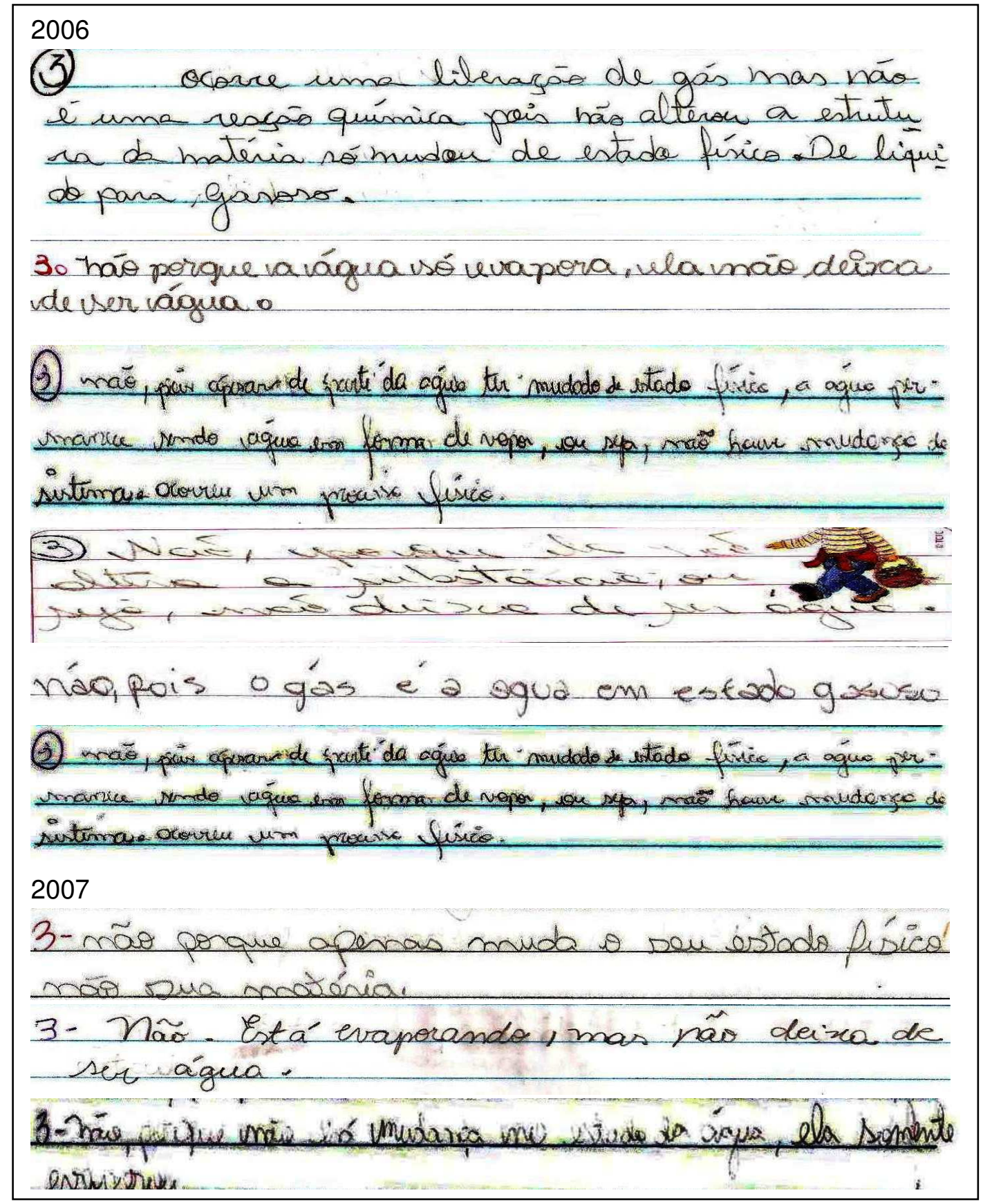

Figura 5.19. Exemplos de respostas classificadas na categoria Amontoados Sincréticos e Pensamento por Complexos. ${ }^{91}$

${ }^{91}$ Cf. nota 88 deste capítulo. 
Justificativas semelhantes se encontram nas mensagens "(...) apesar de parte da água ter mudado de estado físico, a água permanece sendo água em forma de vapor, ou seja, não houve mudança de sistema (...)" - alunos do ano de 2006; "(...) está evaporando, mas não deixa de ser água (...)" - alunos do ano de 2007 e "(...) porque a água só evapora, ela não deixa de ser água (...)" - alunos do ano de 2006. Os atributos em comum entre estes e os outros exemplos é a observação da transformação que ocorre no sistema água e a identificação do processo como evaporação.

Como notamos que estes educandos não são capazes de identificar as características do sistema antes e após a transformação e as causas que levaram a esta transformação, então, podemos inferir que em nenhum destes exemplos encontram-se expressões que se aproximam da formação do conceito, que segundo VIGOTSKI (2005) somente se constrói verdadeiramente na mente dos seres humanos a partir da adolescência.

"(...) Vygotsky conclui que a capacidade do adolescente de formar conceitos
antecede em muito sua capacidade de defini-los. Contudo, se
considerarmos as situações escolares, muitas vezes o aluno é capaz de
definir um objeto, quando sabemos que ainda não formou o conceito
(NÉBIAS, 1999, p. 135)."

Entretanto, este grupo de adolescentes está criando, ao acaso, justificativas para o reconhecimento das transformações dos sistemas, porém sem conseguir fazê-los com êxito. Assim, podemos dizer que, como a maioria dos alunos não construiu o conceito de transformação, também não são capazes de identificar as características particulares de cada sistema em processo, retornando o seu pensamento à um processo primitivo de tentativas aleatórias de explicação das mudanças.

Confirmamos o descrito por VIGOTSKI (2005) e NÉBIAS (1999), com as mensagens da Figura 5.19, que apresenta termos como, “(..) não alterou a estrutura da matéria, só mudou de estado físico (...)”, “(...) ela não deixa de ser água (...)”, “(..) a água permanece sendo água em forma de vapor (...)" e "(...) não altera a substância (...)". Estes termos evidenciam a dificuldade dos educandos em expressar verbalmente um conceito, ficando muito aquém de seu emprego em uma situação concreta, ou seja, estes termos estão sendo colocados a fim de enfatizar a mudança de estado físico e a não ocorrência de transformação química.

Este tipo de pensamento está baseado na procura de atributos em comuns, que possibilitem a generalização ou a diferenciação das peculiaridades pertinentes a cada sistema, para em seguida se formarem conceitos significativos em sua estrutura cognitiva.

Por meio da atividade mental, necessária para a abstração e formação do conceito, os educandos internalizam as propriedades de cada material em transformação para poderem, posteriormente, utilizar-se dos conceitos construídos em situações que se fizerem 
pertinentes. Dessa forma, os conceitos construídos por meio da aprendizagem escolar não serão somente utilizados para solucionar problemas existentes no meio acadêmico, mas também no uso em situações concretas, que extrapolem o cotidiano da sala de aula.

\subsection{Comparação entre as etapas de formação do conceito de transformação nas diferentes atividades propostas}

A Tabela 5.8 apresenta a comparação entre as etapas de formação do conceito de transformação, com dados provenientes das Tabelas 5.3 a 5.7, organizadas a partir das mensagens expressas nas quatro atividades selecionadas para análise do conceito proposto.

Tabela 5.8 - Comparação entre as etapas de formação do conceito de transformação e as atividades propostas para análise.

\begin{tabular}{|c|c|c|c|c|c|c|c|c|c|}
\hline \multirow{3}{*}{ Categorias } & \multirow{3}{*}{ Subcategorias } & \multicolumn{4}{|c|}{$1^{\mathrm{a}}$ e $2^{\mathrm{a}}$ atividades } & \multicolumn{2}{|c|}{$3^{a}$ atividade } & \multicolumn{2}{|c|}{ 4a atividade } \\
\hline & & \multicolumn{2}{|c|}{2006} & \multicolumn{2}{|c|}{2007} & \multirow[t]{2}{*}{2006} & \multirow[t]{2}{*}{2007} & \multirow[t]{2}{*}{2006} & \multirow[t]{2}{*}{2007} \\
\hline & & $\begin{array}{c}\text { Tabela } \\
\text { Individual }\end{array}$ & $\begin{array}{l}\text { Tabela } \\
\text { Coletiva }\end{array}$ & $\begin{array}{c}\text { Tabela } \\
\text { Individual }\end{array}$ & $\begin{array}{l}\text { Tabela } \\
\text { Coletiva }\end{array}$ & & & & \\
\hline \multirow[b]{2}{*}{$\begin{array}{l}\text { Amontoados } \\
\text { Sincréticos }\end{array}$} & Tentativa e erro & $29 \%$ & $46 \%$ & $44 \%$ & $23 \%$ & $9 \%$ & $30 \%$ & $46 \%$ & $78 \%$ \\
\hline & $\begin{array}{l}\text { Organização do } \\
\text { Campo Visual }\end{array}$ & $44 \%$ & $29 \%$ & $14 \%$ & $13 \%$ & $18 \%$ & $25 \%$ & --- & $4 \%$ \\
\hline TOTAL & & $73 \%$ & $75 \%$ & $58 \%$ & $36 \%$ & $27 \%$ & $55 \%$ & $46 \%$ & $82 \%$ \\
\hline $\begin{array}{l}\text { Pensamento } \\
\text { por } \\
\text { Complexos }\end{array}$ & Pseudoconceito & $15 \%$ & $15 \%$ & $26 \%$ & $48 \%$ & $67 \%$ & $45 \%$ & $49 \%$ & $18 \%$ \\
\hline TOTAL & & $15 \%$ & $15 \%$ & $26 \%$ & $48 \%$ & $67 \%$ & $45 \%$ & $49 \%$ & $18 \%$ \\
\hline \multirow{2}{*}{$\begin{array}{l}\text { Pensamento } \\
\text { Conceitual }\end{array}$} & $\begin{array}{l}\text { Conceitos } \\
\text { Potenciais }\end{array}$ & --- & --- & $2,0 \%$ & --- & $2 \%$ & --- & $2 \%$ & --- \\
\hline & $\begin{array}{l}\text { Conceitos } \\
\text { Abstratos }\end{array}$ & --- & --- & $0,5 \%$ & --- & $2 \%$ & --- & --- & --- \\
\hline TOTAL & & $-\cdots$ & $-\cdots$ & $2,5 \%$ & --- & $4 \%$ & $-\cdots$ & $2 \%$ & --- \\
\hline Outros & & $12 \%$ & $10 \%$ & $13,5 \%$ & $16 \%$ & $2 \%$ & --- & $3 \%$ & --- \\
\hline TOTAL & & $100 \%$ & $100 \%$ & $100 \%$ & $100 \%$ & $100 \%$ & $100 \%$ & $100 \%$ & $100 \%$ \\
\hline
\end{tabular}

Da comparação entre os dados obtidos a partir das quatro atividades, podemos observar que, de $73 \%$ das mensagens expressas pelos educandos do ano de 2006 na Tabela Individual e $75 \%$ na Tabela Coletiva, este número se reduziu para $27 \%$ e $46 \%$, respectivamente, na terceira e quarta atividades na categoria "Amontoados Sincréticos".

Este fato nos leva a corroborar o pensamento de ROSA e SCHNETZLER (1998), quando apontam para estudos feitos sobre as transformações químicas, para o fato de grande parte dos pesquisados observarem a transformação dos materiais apenas no campo 
fenomenológico, confundindo transformações químicas com mudança de estado físico ou pela observação de mudança de cor, forma ou estado.

$\mathrm{Na}$ comparação entre as quatro atividades destacadas para análise da construção do conceito de transformação dos materiais, podemos enfatizar informações, como:

a) A categoria "Outros" diminuiu consideravelmente em relação à primeira atividade analisada, ou seja, de 12\% e 10\% em 2006 e 13,5\% e 16\% em 2007, os dados ficaram praticamente nulos, em relação à terceira e quarta atividades;

b) $\mathrm{Na}$ categoria "Amontoados Sincréticos", a segunda atividade apresentou menor número de mensagens, sendo $27 \%$ para 2007 na Tabela coletiva e $36 \%$ na terceira atividade para o ano de 2006;

c) $\mathrm{Na}$ categoria "Pensamento por Complexos", a primeira e segunda atividades apresentaram menor número de mensagens (15\%) no ano de 2006, tanto na Tabela Individual como também na Coletiva e $18 \%$ para o ano de 2007, na quarta atividade;

d) Na categoria "Pensamento Conceitual", a primeira atividade não apresentou dados para o ano de 2006, e apenas 2,5\% para o ano de 2007 (na Tabela Individual); na terceira e quarta atividades não apresentou dados para o ano de 2007 e apenas para 2006, $4 \%$ na terceira atividade e $2 \%$ na quarta atividade;

e) $\mathrm{Na}$ primeira atividade, 44\% das mensagens do ano de 2006 encontram-se na subcategoria "Organização do Campo Visual" para a Tabela Individual, já na terceira atividade 67\% das respostas dos alunos de 2006 estão classificadas na subcategoria "Pseudoconceito" e na quarta atividade 49\% das respostas, desses mesmos educandos, estão nesta mesma subcategoria;

f) $\mathrm{Na}$ primeira atividade $44 \%$ das mensagens do ano de 2007 encontram-se na subcategoria "Tentativa e Erro", já na terceira atividade 45\% das respostas dos alunos de 2007 estão classificadas na subcategoria "Pseudoconceitos" e na quarta atividade localizam-se, 78\% das respostas dos educandos do ano de 2007 na subcategoria, "Tentativa e Erro";

Dados semelhantes foram encontrados em artigo escrito por OLIVEIRA et al. (2008), quando encontraram em seus estudos que $90 \%$ dos alunos de uma escola pública utilizamse de justificativas no campo macroscópico para exemplificar a transformação dos materiais. Neste caso, a professora da turma iniciou o estudo das transformações químicas com o auxílio de materiais que enfatizavam a aprendizagem no âmbito fenomenológico. 
Entretanto, ao observarmos a primeira, segunda, terceira e quarta atividades notamos que os alunos do ano de 2006 evoluíram conceitualmente, pois notamos que de 15\% das mensagens classificáveis na subcategoria "Pseudoconceito", na primeira atividade, passou para $67 \%$ e $49 \%$, respectivamente, na terceira e quarta atividades selecionadas para coleta de dados.

Contudo, para o ano de 2007, inicialmente $26 \%$ das mensagens encontram agrupadas na subcategoria "Pseudoconceito". Este número aumenta quando analisada a terceira atividade (45\%). Porém, ao observarmos a quarta atividade notamos que este número caiu para $18 \%$ na subcategoria "Pseudoconceito" e aumentou para $78 \%$ na subcategoria "Tentativa e Erro". Daí podermos inferir que parte destes educandos não evoluiu conceitualmente.

Nota-se, também um retorno do pensamento dos alunos a um nível descritivo mais primitivo (VIGOTSKI, 2005), para justificar o processo de transformação dos sistemas, pois o conflito cognitivo gerado na zona de desenvolvimento proximal destes educandos desencadeou a procura por justificativas para as transformações ocorridas, como apresentado na $4^{\underline{a}}$ atividade. Porém, as justificativas empregadas ainda não haviam sido interiorizadas pelos alunos, o que ocasionou a busca por informações que já possuíam para tentar justificar a transformação.

Podemos também ressaltar que as idéias prévias dos alunos estão presentes nas mensagens encontradas para as respostas aos questionamentos feitos e, portanto, deduzimos que seus conhecimentos provenientes do cotidiano estão influenciando seu aprendizado escolar devido à interrelação existente entre ambos.

Observamos algumas expressões em que os alunos colocam seu pensamento através de uma linguagem mais próxima e coerente com o significado do conceito de transformação, por exemplo, quando o aluno discute sobre a ocorrência ou não de reação química durante o aquecimento da água, em justificativa classificável na subcategoria "Conceito Potencial", "Não. Apesar de parte da água ter mudado de estado físico, a água permanece sendo água em forma de vapor, ou seja, não houve mudança de sistema”, ele reconhece mudanças nas características iniciais, porém, ao afirmar que não houve mudança no sistema demonstra que não compreendeu o processo.

Não podemos dizer que houve desenvolvimento na estrutura cognitiva de todos os alunos, pois eles ainda precisam de mais atributos, relacionáveis aos sistemas em processo, para poderem ressignificar o conceito de transformação. Um exemplo da necessidade de maiores atributos para poderem ressignificar o conceito de transformação se dá quando 
analisamos outra explicação do educando para o aquecimento da água, "Não. Está evaporando, mas não deixa de ser água", resposta agrupada na subcategoria "Pseudoconceito". Neste comentário, notamos que ele tenta explicar o que acontece quando se aquece o material presente no sistema, porém sua explicação não elucida as características iniciais e finais do material e também não relaciona a causa da evaporação, ele somente sabe que o material está evaporando, porém não estabelece justificativas para o fato.

Para justificar suas respostas, alguns alunos utilizaram-se de conhecimento adquiridos em outros momentos, ou seja, no seu dia-a-dia ou no contato com outras disciplinas do currículo escolar para organizarem suas respostas. De forma análoga, destaca-se a pesquisa com alunos de Ensino Médio, realizada por GALÃO et al. (2003), na qual se observou nas atividades dos educandos a presença de conhecimentos adquiridos de forma interdisciplinar, como também, a menção a conceitos científicos relacionados a conceitos provenientes de seu cotidiano.

Ao confrontarmos nossas observações com pesquisas realizadas por outros pesquisadores, notamos que a mediação exercida pelo professor é fundamental para o desenvolvimento intelectual dos educandos, como afirmam JUNIOR et al. (2008).

De modo semelhante, em pesquisas realizadas por PEREIRA et al. (2007) e ULLER (2006), ambas com alunos de Ensino Médio, observa-se que, em relatos desses educandos, a ação do professor pode influenciar a aprendizagem dos educandos, pois a relação educativa que mantêm entre si é uma ação indissociável dos processos de ensino e aprendizagem, mantidos no ambiente escolar, ou seja, as estratégias utilizadas pelo professor na dinâmica de uma aula, é fundamental para a criação de vínculos entre educandos e educador, podendo influenciar positivamente a aprendizagem escolar.

Observamos, nesta Dissertação, que a prática da ação colaborativa pode ter influenciado o conhecimento dos educandos, por exemplo, na terceira atividade selecionada para análise dos dados encontramos a justificativa de reconhecimento do sistema em transformação, classificável na subcategoria "Pseudoconceito", "Passou do sólido para o líquido, liberou gases e mudou de cor vermelho passou a ser prateado". Nesta explicação podemos dizer que o aluno reconhece um processo no sistema, observando características anteriores à mudança, como a variação da coloração, porém não elucida o que gerou esta modificação. Portanto, podemos inferir que este aluno não possui atributos suficientes para reelaborar sua concepção do conceito de transformação dos materiais. 
Admitimos, então, que o conhecimento que está sendo construído dentro do ambiente socializador da escola ganhou um significado para parte deste grupo de alunos que tinham um objetivo em comum, que era o de reconhecer as características iniciais e finais de sistemas em transformação, como também, a comparação entre eles. Neste caso, os alunos estiveram em contato com seus pares (colegas de classe) e com outra pessoa mais experiente (professora) nos processos de ensino e aprendizagem, numa relação dialógica em que os processos se influenciam reciprocamente na construção do conhecimento e no desenvolvimento intelectual, tanto do educando como do educador.

\subsection{Análise dos dados apresentados por três estudantes participantes da pesquisa}

A fim de reconhecer a modificação na concepção do conceito de transformação para transformação química a partir de atividades existentes no PROQUIM e realizadas colaborativamente, analisamos a ressignificação do conceito de transformação, nas atividades selecionadas para estudo, com três alunos participantes da pesquisa.

Para efeito da pesquisa e com a finalidade de preservar a identidade dos alunos, seus nomes foram modificados. O nomes dados aos alunos selecionados para acompanhamento das atividades foram: Alex_2006, Carlos_2007 e Elena_2007.

Das quatro atividades selecionadas para análise a única que foi realizada individualmente foi a construção da Tabela Individual (primeira atividade), pois tinha como objetivo identificar a concepção espontânea destes educandos a respeito do conceito de transformação dos materiais.

Os conhecimentos prévios dos alunos foram considerados para a construção das Tabelas Coletivas (segunda atividade), a construção desta se deu a partir da socialização dos sistemas evocados nas Tabelas Individuais, porém os sistemas agora mencionados na Tabela Coletiva, possuíam maiores informações que remetiam o pensamento dos educandos a identificar características dos materiais antes e após o processo de transformação, bem como a causa que origino este processo.

A terceira atividade fornecia informações sobre o problema desde o seu enunciado e que deveriam ser reconhecidos pelos educandos, como evidências da reação química.

A quarta atividade exigia do educando uma abstração mais significativa e o uso de informações que foram se enredando em sua estrutura cognitiva para a construção do 
conceito de transformação dos materiais, o qual deveria ser utilizado para identificar se existiam ou não evidências de reação química no processo de aquecimento da água.

\subsubsection{Análise da primeira atividade realizada por Alex_2006, Carlos_2007 e Elena_2007}

A primeira atividade a ser analisada será a Tabela Individual dos aluno Alex_2006, Carlos_2007 e Elena_2007.

Como já foi dito anteriormente, a primeira atividade consistia em relacionar, individualmente, dez transformações e justificar como se pode reconhecer a transformação ocorrida no sistema mencionado.

O objetivo desta atividade era resgatar as concepções prévias dos educandos e suas percepções de mudanças presentes em seu dia-a-dia.

A Figura 5.20 apresenta a Tabela Individual do aluno Alex_2006:

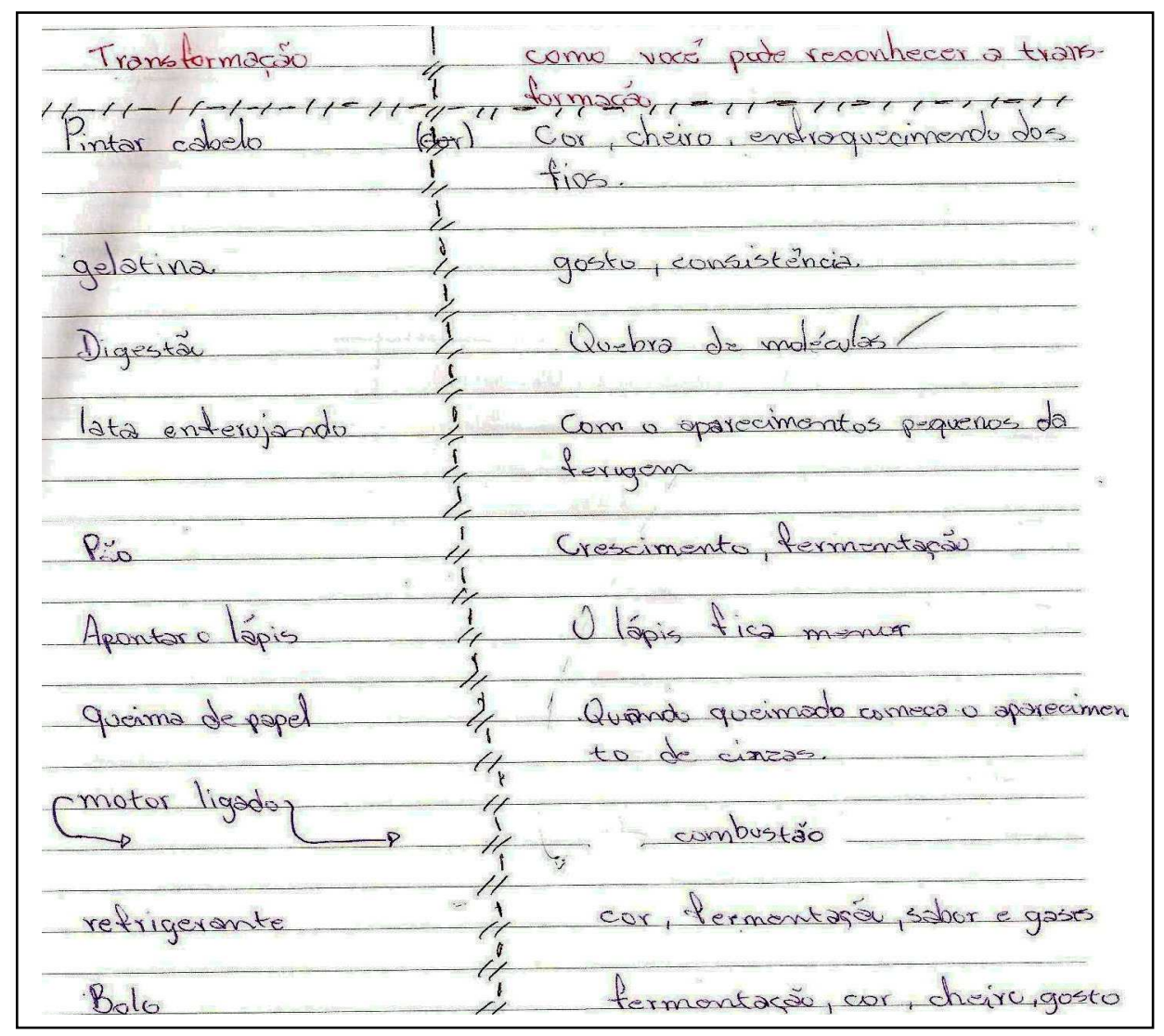

Figura 5.22. Tabela Individual do aluno Alex_2006. 
Podemos observar que o aluno Alex_2006 seguiu corretamente as instruções indicadas no material instrucional ao listar os dez sistemas em processo de transformação e suas justificativas de reconhecimento.

Nos sistemas Pintar cabelo, Digestão, Lata enferrujando, Apontar lápis e Queima de papel, percebemos que o aluno está se remetendo à processos que poderão ocasionar a transformação dos sistemas mencionados. Por exemplo, no sistema Pintar o cabelo, a conseqüência observada por Alex_2006 para esta ação é: cor, cheiro e enfraquecimento dos fios.

Podemos inferir que nesta justificativa de reconhecimento de evidências de transformação, há predominância de aspectos macroscópicos, porém quando Alex_2006 menciona enfraquecimento dos fios está recorrendo a conhecimentos provenientes do dia-adia para se justificar, sem mencionar o que poderia ter ocasionado o enfraquecimento dos fios. Assim, a evidência cor e cheiro foram classificadas na subcategoria Organização do Campo Visual e enfraquecimento dos fios foi classificada na subcategoria Tentativa e Erro.

As outras justificativas de reconhecimento: quebra de moléculas (subcategoria Tentativa e Erro), com o aparecimento pequeno da ferrugem (subcategoria Organização do Campo Visual), o lápis fica menor (subcategoria Organização do Campo Visual) e quando queimado começa o aparecimento de cinzas (subcategoria Organização do Campo Visual) estão classificadas na categoria Amontoados Sincréticos. Todos os sistemas mencionados até agora apresentam um caráter dinâmico do processo.

Gelatina, pão, motor ligado, refrigerante e bolo são sistemas que já se encontram finalizados, portanto, com a exceção de motor ligado (sistema que pode gerar a modificação de um material) são classificados como sistemas de caráter estático.

Quando se analisa as justificativas de reconhecimento temos: gosto (Outros), consistência (Organização do Campo Visual), crescimento (Pseudoconceito), fermentação (Pseudoconceito), combustão (Tentativa e Erro), cor (Organização do Campo Visual), sabor (Outros), gases (Organização do Campo Visual), cheiro (Outros), percebe-se que o aluno Alex_2006 está tentando justificar o reconhecimento dos sistemas em transformação, porém existe confusão em sua estrutura cognitiva.

Alex_2006 utiliza-se de justificativas que indicam ações que podem ocasionar a transformação dos sistemas, como, crescimento, fermentação e combustão, porém não identifica as características dos sistemas antes e após a transformação. Também não menciona as conseqüências ocasionadas por estes processos. 
A Figura 5.21 apresenta a Tabela Individual do Carlos_2007:

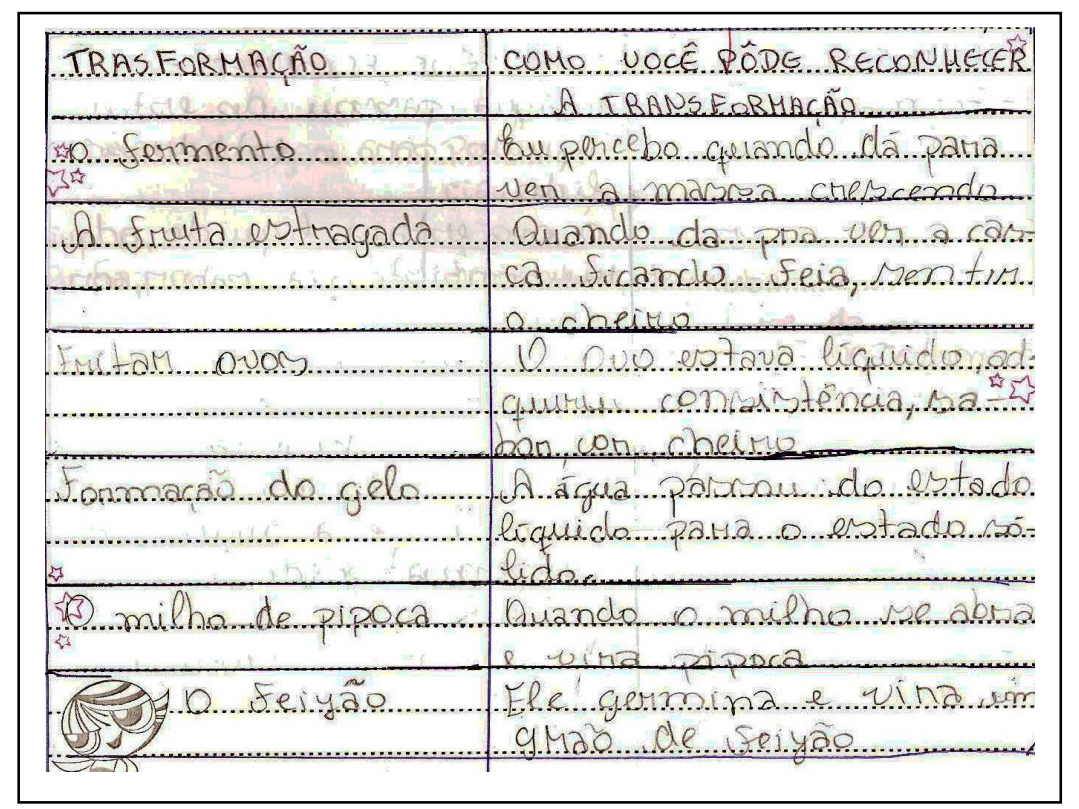

Figura 5.21. Tabela Individual do aluno Carlos_2007.

Observamos que o aluno Carlos_2007 não listou os dez sistemas solicitados no material instrucional, colocando em sua tabela apenas seis sistemas.

Nos sistemas Fritar ovos e Formação do gelo, percebemos que o aluno está se remetendo à processos que poderão ocasionar a transformação dos sistemas mencionados. Por exemplo, no sistema Fritar ovos Carlos_2007 reconhece a mudança através de percepções no âmbito macroscópico. Ele cita mudança na consistência, cor, cheiro (subcategoria Organização do Campo Visual) como evidência da transformação.

Já no sistema Formação do gelo ele menciona a mudança de estado físico de líquido para sólido (subcategoria Tentativa e Erro), porém ainda não relaciona o fato à variações de temperatura. Estes dois sistemas tem um caráter dinâmico.

Os outros sistemas mencionados por Carlos_2007 apresentam um caráter estático, porém quando se analisa a justificativa de reconhecimento da transformação percebe-se um caráter dinâmico no processo. Por exemplo, quando o aluno menciona "(...) massa crescendo (...)" - subcategoria Tentativa e Erro, “(...) casca ficando feia (...)" - subcategoria Tentativa e Erro, "(...) o milho se abre e vira pipoca (...)"- subcategoria Tentativa e Erro, "(...) germina e vira um grão de feijão (...)" - subcategoria Tentativa e Erro, nota-se que o aluno implicitamente difere os estados inicial e final dos sistemas.

Observamos que quando Carlos_2007 menciona "(...) o milho se abre e vira pipoca (...)", como evidência da transformação do sistema, mas não consegue relacionar a causa 
para a transformação do milho, ele somente cita o que é perceptível macroscopicamente, ou seja, apenas relata o que observa e tenta criar uma explicação para a transformação do sistema sugerido. Já quando fala em germinação nota-se que utilizou um conhecimento adquirido em outros momentos para aplicá-lo à justificativa de reconhecimento da transformação ocorrida.

A Figura 5.22 apresenta a Tabela Individual construída pela aluna Elena_2007:

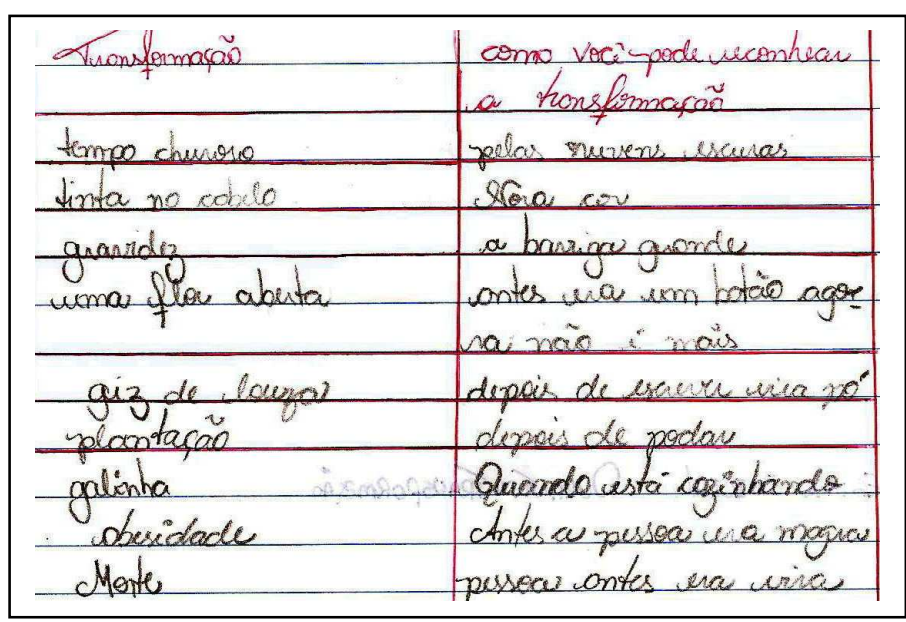

Figura 5.22. Tabela Individual da aluna Elena_2007.

A aluna Elena_2007 listou nove transformações e suas justificativas de reconhecimento, sendo que a atividade solicitava dez sistemas em transformação.

Todos os sistemas apresentados pela aluna não indicam transformações e podem ser classificadas como sistemas estáticos.

Com exceção das evidências Pelas nuvens escuras e $A$ barriga grande, ambas classificáveis na subcategoria Tentativa e Erro, todas as outras evidências de reconhecimento de transformação dos sistemas, mencionadas por Elena_2007, podem ser consideradas de caráter dinâmico.

Podemos inferir que, dos nove sistemas apresentados por Elena_2007, em sete deles a aluna indicava que havia ocorrido modificações das características iniciais dos sistemas, recorrendo ao conhecimento proveniente do cotidiano para poder justificá-los.

Nota-se, também, que Elena_2007 recorre a observações no âmbito macroscópico para justificar o reconhecimento das evidências dos sistemas mencionados durante a construção de sua Tabela Individual. Em pesquisa semelhante, OLIVEIRA et al. (2008) realizou investigação a respeito da concepção do conceito de transformação química em educandos de Ensino Médio. 
OLIVEIRA et al. (2008) requisitou aos estudantes participantes de sua investigação que escrevessem sobre transformações químicas e que, se necessário, dessem exemplos. Da análise dos resultados obtidos observou que maioria dos educandos utilizavam-se adequadamente de exemplos no âmbito macroscópico. Já quando utilizavam exemplos a nível microscópico, suas observações a respeito das transformações químicas eram em grande parte inadequadas.

Resultados semelhantes a pesquisa de OLIVEIRA et al. (2008) encontram-se na pesquisa realizada para esta Dissertação. Nota-se a predominância de aspectos macroscópicos nas observações realizadas pelos educandos quando construíram as Tabelas Individuais solicitadas para a primeira atividade. Provavelmente, este fato tenha ocorrido porque observar o que é perceptível macroscopicamente seja mais significativo do que observar o que necessita de maiores abstrações e generalizações para serem analisados. Tanto na pesquisa de OLIVEIRA et al. (2008) como nesta Dissertação, as atividades procuravam relacionar o cotidiano dos educandos com os problemas propostos.

A segunda atividade selecionada para análise foi realizada coletivamente e apresentou $75 \%$ das justificativas de reconhecimento de transformação dos sistemas na categoria Amontoados Sincréticos. Da mesma forma que a análise feita na Tabela Coletiva das Turmas do ano de 2006 e 2007, podemos inferir que Alex_2006, Carlos_2007 e Elena_2007 necessitam de mais informações para ancorar ao conceito subsunçor "transformação", já existente em suas estruturas cognitivas, para poder ressignificá-lo.

\subsubsection{Análise da terceira atividade realizada por Alex_2006, Carlos_2007 e Elena_2007}

A terceira atividade em destaque, para análise, foi:

"Aqueceu-se um sólido vermelho num tudo de ensaio. Depois de algum tempo de aquecimento detectou-se a liberação de um gás incolor e a formação de um líquido prateado. Pergunta-se: Ocorreu reação química? Qual é a evidência?"

Nesta atividade nota-se que existe uma afirmação que contextualiza o problema. $\mathrm{Na}$ afirmação encontram-se informações sobre o sistema antes e após o aquecimento. Da pergunta “Ocorreu reação química? Qual é a evidência?”, o aluno Alex_2006 afirma que sim e que a evidência é a mudança de cor. As respostas escritas por Alex_2006, encontram-se na Figura 5.23. 


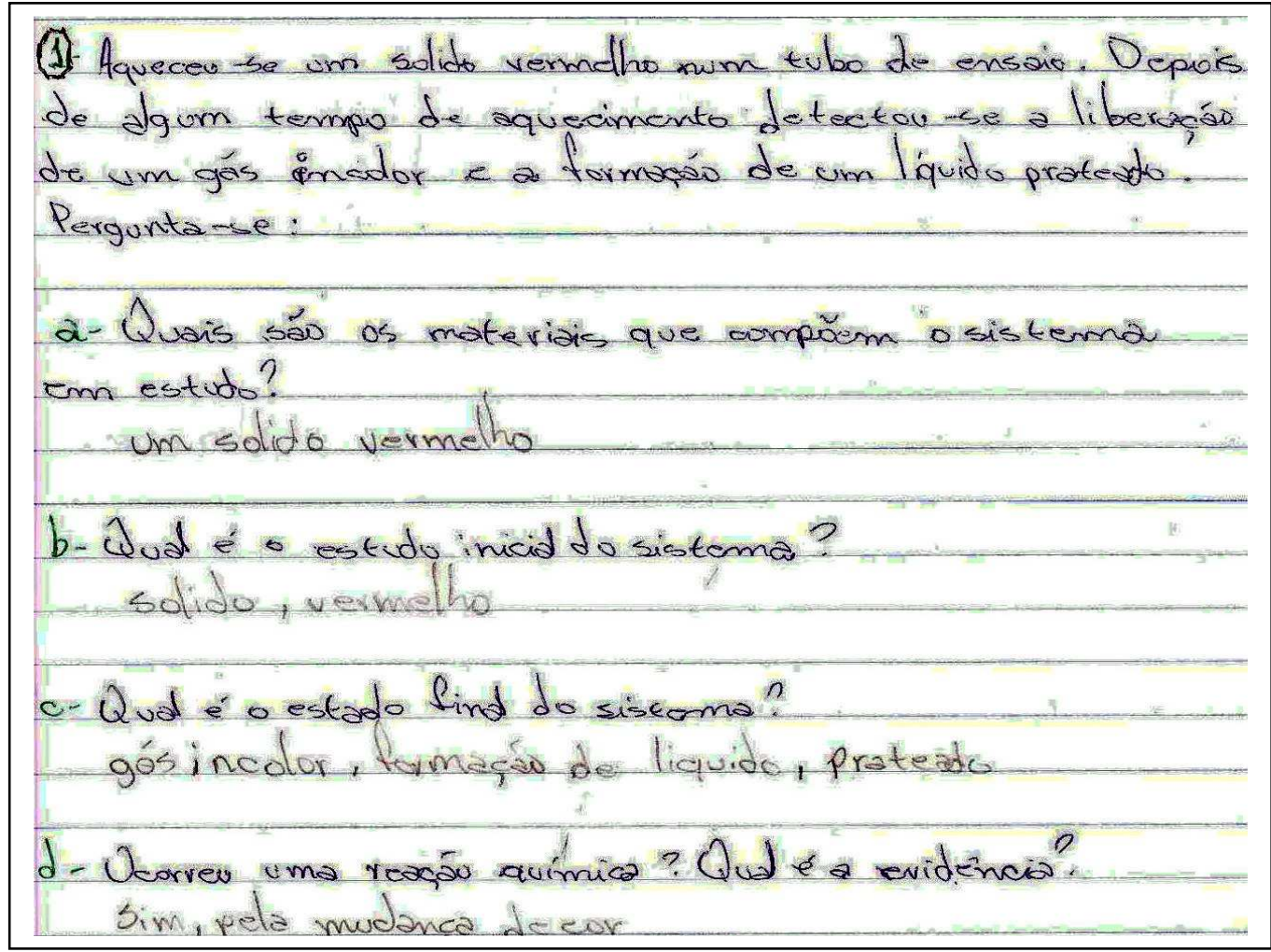

Figura. 5.23. Resposta do aluno Alex_2006 para a terceira atividade.

Alex_2006 destaca a mudança de cor como evidência da transformação do sistema, porém não recorre a nenhuma outra evidência apresentada no problema para enfatizar sua resposta. Neste caso, entendemos que o aluno nota uma modificação no sistema, mas ainda não reflete sobre outras informações fornecidas na contextualização do problema, como, por exemplo, a mudança de estado físico do material. Daí podemos dizer que a resposta do aluno está classificada na subcategoria Organização do Campo Visual.

A mesma questão foi respondida pelo aluno Carlos_2007, e está na Figura 5.24:

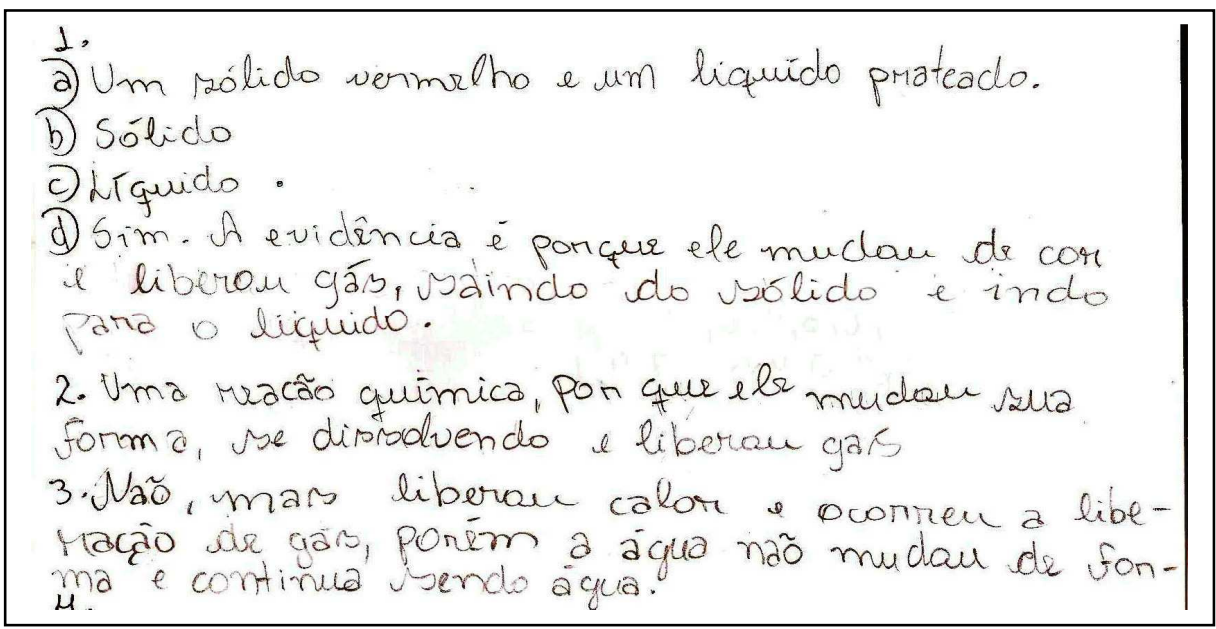

Figura 5.24. Resposta do aluno Carlos_2007 para a terceira e quarta atividades. 
O aluno afirma que houve uma reação química e que as evidências são: mudança de cor, liberação de gás e mudança de estado físico. O conjunto das informações obtidas a partir da resposta de Carlos_2007 são classificáveis na subcategoria Pseudoconceitos, o que indica que este aluno está se aproximando de um pensamento mais objetivo e se afastando do sincretismo, ou seja, as informações que se encontravam desordenadas em seu pensamento agora estão mais organizadas permitindo que o aluno se aproxime da construção do conceito verdadeiro.

Apresentamos a resposta da aluna Elena_2007 na Figura 5.25. Elena_2007 reconhece a reação química através da mudança de coloração e de estado físico. Sua resposta também está classificada na subcategoria Pseudoconceito e da mesma forma que para o aluno Carlos_2007 e outros 45\% dos alunos deste mesmo período letivo, a aluna está apresentando maior ordenação em seu pensamento e já consegue relacionar maiores informações quando descreve um sistema em transformação.

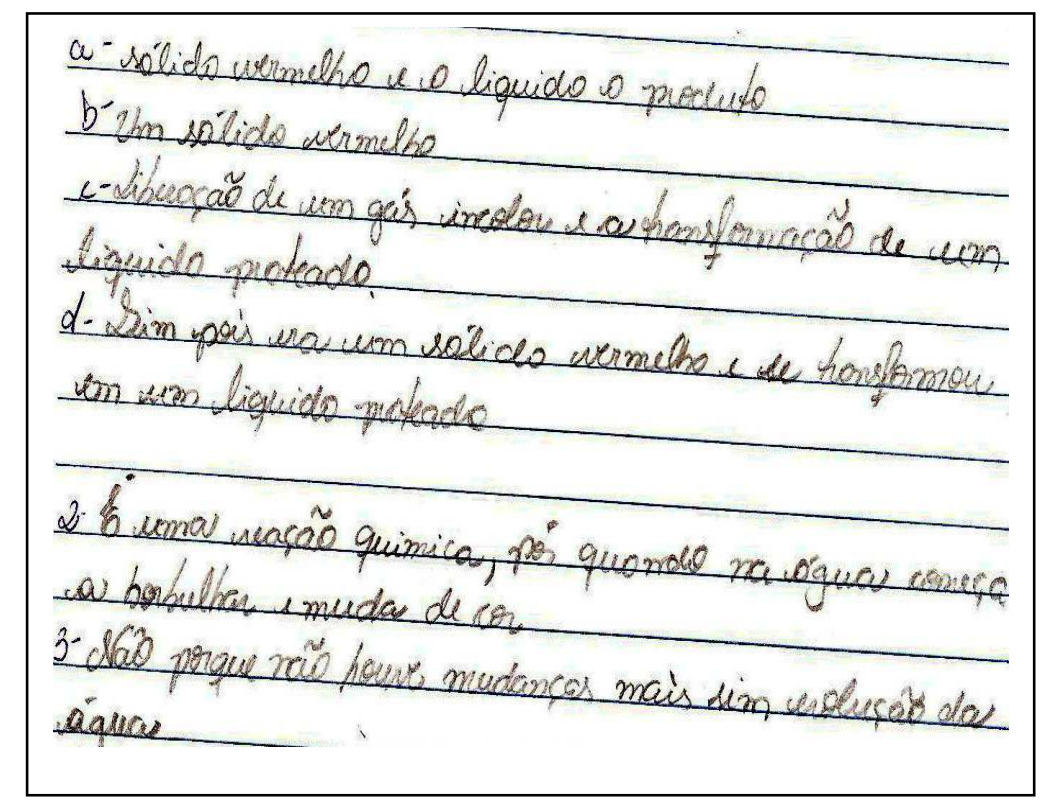

Figura 5.25. Resposta da aluna Elena_2007 para a terceira e quarta atividades.

Destacamos a necessidade destes alunos refletirem mais sobre as informações que são fornecida, ou seja, a interpretação dos dados fornecidos no enunciado precisam receber maior atenção.

\subsubsection{Análise da quarta atividade realizada por Alex_2006, Carlos_2007 e Elena_2007}

Na quarta atividade selecionada para análise: 
"Quando se aquece a água há liberação de um gás. Está ocorrendo uma reação química? Explique sua resposta."

Resposta de Alex_2006: “Não, pois o gás é a água em estado gasoso.”

A resposta de Alex_2006 está classificada na categoria Pensamento por Complexos. Isto significa dizer que o aluno está se aproximando do pensamento objetivo e distanciandose do sincretismo, porém ainda precisando refletir mais sobre as informações que são fornecidas durante os processos colaborativos em que tanto educandos, como também a professora-pesquisadora, trocaram informações sobre as situações apresentadas nas quatro atividades. Enfim, pode-se dizer que Alex_2006 ressignificou o conceito de transformação, da mesma forma que outros $49 \%$ dos alunos participantes da pesquisa do ano de 2006.

A resposta de Carlos_2007 está apresentada na Figura 5.24. Carlos_2007 diz que Não houve reação química, "(...) mas liberou calor e ocorreu a liberação de gás, porém a água não mudou de forma e continua sendo água”. Esta resposta é classificável na subcategoria Tentativa e Erro.

Percebe-se que este aluno está passando por um conflito em sua estrutura cognitiva, pois foi apresentado à ele uma situação em que necessitou retornar a um pensamento mais primitivo para conseguir formular uma resposta para a questão. Por exemplo, quando Carlos_2007 se refere a liberação de um gás, pode-se inferir que para ele o sistema que estava em aquecimento liberou um outro material como gás, o qual não seria a água.Para o aluno a liberação de calor também tem característica de material que pode ser transformado numa reação química. Quando Carlos_2007 fala que a água não mudou de forma está desconsiderando a mudança de estado físico como evidência de processo em transformação.

Nota-se que este aluno retornou ao pensamento sincrético para buscar mais informações para poder justificar porque este sistema em transformação não sofre reação química. VIGOTSKI (2005) afirma que este retorno do pensamento ao seu estado mais primitivo é uma das etapas da construção do conhecimento, pois o aluno reconhece que não possui informações suficientes para formação do conceito referenciado, assim, busca atributos para a significação do símbolo em outros momentos de aprendizagem que foram mais significativo e tenta, a partir do conhecimento que já possui, dar significado ao conceito em construção.

A resposta da aluna Elena_2007 para a quarta atividade selecionada para análise do conceito de transformação está apresentada na Figura 5.25. A aluna respondeu esta 
atividade dizendo que: Não houve reação química, "(...) porque não houve mudanças, mais sim evolução da água."

Pode-se observar uma confusão na resposta de Elena_2007. Apesar de afirmar que não houve reação química, Elena_2007 não explica porque não houve mudanças no sistema. Quando fala em "evolução" da água, acreditamos que se referia a "evaporação" da água. Neste caso, fica evidente que a aluna precisa de maiores informações sobre a atividade em questão e que os momentos de discussão coletiva do qual fez parte não foram suficientes para que pudesse ressignificar o conceito em estudo. $O$ mesmo foi observado para os outros $78 \%$ dos alunos do ano de 2007 quando analisada a quarta atividade.

Notamos que Alex_2006, Carlos_2007 e Elena_2007 evoluíram conceitualmente durante o processo de construção do conceito de transformação dos materiais. Apesar destes alunos ainda necessitarem de maiores informações para ressignificar o conceito, notamos já conseguem refletir melhor sobre os atributos do conceito em estudo.

Num estudo semelhante realizado por SANTOS \& QUADROS (2008) com alunos de primeiro ano de Ensino Médio, sobre transformações químicas, com metodologia de ensino análoga à utilizada nesta Dissertação, ou seja, com aulas dialogadas, incentivo à participação dos educandos e procedimentos experimentais em meio à uma aula teórica, os autores identificaram que seus alunos evoluíram conceitualmente quanto à construção do conceito referenciado.

Assim como grande parte dos alunos participantes da pesquisa que realizamos, os alunos de SANTOS \& QUADROS (2008) também justificam o reconhecimento de transformação ocorridas nos sistemas pela mudança de estado físico e formação de um novo material. Estes autores ainda notaram, assim como observado nesta Dissertação, que os alunos ao final da terceira atividade proposta, estão refletindo mais sobre o problema proposto.

SANTOS \& QUADROS (2008), observaram de forma parecida com nossas análises que mesmo os alunos que utilizaram de respostas mais elaboradas para justificar 0 reconhecimento dos sistemas em transformação, eles não deixaram de recorrer ao conhecimento proveniente do cotidiano para explicar as evidências mencionadas.

Enfim, podemos dizer que os educandos participantes desta discussão precisam de mais informações para construir significativamente o conceito de transformação dos materiais. 


\section{Capítulo 6}

Conclusões 


\subsection{Conclusões}

Há uma gama de conhecimentos que se desenvolvem e se estabelecem a partir do cotidiano. As experiências e relações cotidianas moldam uma forma de conhecer que são fugidias às formas elaboradas pelo conhecimento científico, mas que, no entanto, podem diversas vezes se apropriarem de termos cunhados por um saber mais elaborado, para exprimir relações e alinalisar objetos próximos ao seu dia-a-dia.

Independente da definição que a ciência atribue ao termo transformação, será no contexto de sua experiência cotidiana que o aluno construirá uma teia de relações que resulta, de acordo com os dados pesquisados, em evocações e justificativas de reconhecimento de seus processos de modificação, como por exemplo, o aspecto da cerveja e do refrigerante no copo, o cozimento do ovo, o coamento do café, o apodrecimento de uma fruta, em outras palavras, elementos próximos a sua experiência diária que podem ou não estarem relacionados à concepção de transformação que o professor apresenta.

Exprime-se nessas evocações um significado peculiar, que serve de ponto de partida para que possa ser ressignificado, mediante uma nova experiência e um novo ponto de vista associado ao ambiente escolar, que oferecem a oportunidade para a aproximação entre o científico e o cotidiano, baseado em outras interrelações e linguagens.

Analisando as evocações dos alunos foi possível notar que se não se inserem nos critérios do saber científico, trazem em si, contudo seus pressupostos básicos. Desse modo, um adolescente que não domina os conceitos fundamentais para uma explicação, do ponto de vista do conhecimento químico, para as transformações que envolvem o processo de tingimento dos cabelos, em sua experiência cotidiana nota elementos como cor, cheiro e estabelece a relação causa-conseqüência ao mencionar o "enfraquecimento dos fios".

Em suma, dentro dos processos elencados nas evocações cabem explicações científicas, entretanto, elaboradas dentro de uma linguagem que foge aos livros, exercícios, explicações orais ou conceitos transmitidos, mas que contém em si uma linguagem que se estabeleceu historicamente, mediante a cultura de cada sociedade e que permanece presente no cotidiano fazendo parte do saber comum. 
A partir das atividades realizadas nesta Dissertação e do levantamento de artigos promovido para poder fundamentá-la, percebemos que a estrutura cognitiva dos indivíduos está em constante processo de transformação e a linguagem empregada vai se transformando pelo contato com pessoas que possuem diferentes experiências de vida. Assim, cada vez mais as formas de pensamento encontradas na infância, vão dando lugar ao pensamento conceitual.

O contato com o que parece novo ao adolescente o coloca em constantes conflitos na procura dos significados, podendo gerar dificuldades na aprendizagem escolar, por se depararem com situações que não estão contextualizadas.

O conflito cognitivo gerado inicialmente, na mente dos educandos e ativado na sua Zona de Desenvolvimento Proximal, conduz ao pensamento mais primitivo coexistindo sincreticamente com o pensamento por complexos, onde os conceitos, em potencial, já existem mas, sem os atributos necessários para que o signo em construção ancore informações o suficiente para adquirir um sentido particular e se tornar um símbolo.

Em vista disso, quando os educandos se encontram em situações em que seu repertório de informações não são suficientes para compreendê-las, retornam o seu pensamento à um nível descritivo mais primitivo, como no caso da quarta atividade, que solicitava dos educandos um nível mais elevado de abstração para solucionar o problema proposto. Contudo, a relação colaborativa que se estabeleceu entre os educandos e a professora-pesquisadora foram importantes para que novos atributos fossem interiorizados.

Como a construção do conhecimento é uma ação que se desenvolve no contato com o outro, através de interações com o grupo ao qual se pertence, concluímos, também, que a ação colaborativa, presente na relação existente entre professorapesquisadora e alunos, durante os processos de ensino e aprendizagem de conceitos químicos auxiliou na ressignificação do conceito de transformação.

A relação educador-educando se estabeleceu por um relacionamento existente entre o conhecimento que se iniciou fora do ambiente escolar e foi introduzido no ambiente já organizado, integrando as concepções espontâneas dos alunos ao conhecimento científico.

Assim, para responder as perguntas que surgiram quando da problematização desta Dissertação, analisamos mensagens expressas pelos educandos e percebemos que além de mencionarem fatos presentes em seu cotidiano também se utilizaram de 
modelos dos quais se apropriaram em outros momentos, para justificar transformações em sistemas que não Ihes eram significantes.

Concluímos, então, que a ação colaborativa entre educandos e educadora e a mediação exercida pela professora-pesquisadora não foram suficientes para a construção coletiva do conhecimento, ou seja, essa prática não foi satisfatória para que esses educandos pudessem ressignificar o conceito de transformação para transformação química, sendo necessária a investigação de novas estratégias de ensino para que esses alunos possam adicionar novos atributos ao conceito e posteriormente poder ressignificá-lo.

Além disso, acreditamos no grande valor do conhecimento cotidiano ao permear o conhecimento escolar e enlaçar o desenvolvimento da linguagem ao conhecimento científico a partir do senso comum. Entretanto, é válido mencionar que o uso de atividades experimentais como estratégia motivadora para construção de conceitos científicos não é o único recurso que se pode utilizar em sala de aula.

Ficou claro para nós que a mobilização dos conhecimentos prévios dos educandos é fundamental para a construção do conhecimento científico. Porém, é importante ressaltar que o uso exaustivo de uma mesma estratégia para mobilizar sempre as mesmas habilidades cognitivas pode se tornar exaustivo, tanto para 0 educando como para o educador.

Nesse caso, vale recorrer à outros recursos para motivar os educandos à aprendizagem de conceitos no ambiente escolar, para que depois os mesmos possam ser aplicados em seu cotidiano, através da disseminação dos saberes escolares para seu uso pela sociedade como um todo.

Concluímos ao final de nossa análise, que o conceito de transformação química ainda não havia sido construído pela maioria dos alunos, até o final dos estudos realizados por meio do Capítulo I do PROQUIM. No entanto, outras atividades propostas no material instrucional continuaram a ser aplicadas nos dois períodos letivos.

Devemos lembrar que estes alunos não estavam acostumados com esta prática de ensino empregada pela professora-pesquisadora, mas as discussões ocorridas em aula permitiram que parte dos alunos evoluísse conceitualmente e que seus processos reflexivos na procura por explicações para o reconhecimento dos sistemas em transformação favoreceu suas argumentações e promoveu a construção coletiva do conhecimento. 
Referências 


\section{REFERÊNCIAS ${ }^{92}$}

ABEGG, Ilse; BASTOS, Fábio da Purificação de. Fundamentos para uma prática de ensinoinvestigativa em Ciências Naturais e suas tecnologias: exemplar de uma experiência em séries iniciais. Revista Electrónica de Enseñanza de las Ciências, Ourense, Spain, v. 4, $\mathrm{n}$. 3, mar. 2005. Disponível <http://www.saum.uvigo.es/reec/volumenes/volumen4/ART7_Vol.4_n.3.pdf>. Acesso em: 02 fev. 2009.

ALMEIDA, Maria Elizabeth Bianconcini de. Educação a distância na internet: abordagens e contribuições dos ambientes digitais de aprendizagem. Educação e Pesquisa, São Paulo, v. 29, n. 2, p. 327-340, jul./dez. 2003. Disponível em: <http://www.scielo.br/pdf/ep/v29n2/a10v29n2.pdf>. Acesso em: 15 out. 2009.

ANDRADE, J. B.; VIERIA, P. C.; PINTO, A. C.; CADORE, S.; PARDINI, V.; ZUCCO, C.; Situação Atual, Perspectivas e Necessidades de Investimentos em Química. Centro de Gestão e Estudos Estratégicos: ciência, tecnologia e inovação, Brasília, 2004, p. 1-11. Disponível em: <http://www.cgee.org.br/atividades/redirect.php?idProduto=1600>. Acesso em 10 jul. 2008.

AUSUBEL, D. P. A aprendizagem significativa: a teoria de David Ausubel. São Paulo: Moraes, 1982.

AUSUBEL, David. P. Aquisição e Retenção de Conhecimentos: uma perspectiva cognitiva. Lisboa: Plátano Edições Técnicas. 1aㅗ ed. 2000. 215 p. Disponível em: http://zircon.dcsa.fct.unl.pt/dspace/bitstream/123456789/556/2/Ausubel_2000_Aquisi\%C3\% A7\%C3\%A30\%20e\%20reten\%C3\%A7\%C3\%A30\%20de\%20conhecimentos.p.pdf. Acesso em 16 mar. 2010.

BARBOSA-LIMA, Maria Conceição; CASTRO, Giselle Faur de; ARAÚJO, Roberto Moreira Xavier de. Ensinar, Formar, Educar e Instruir: a Linguagem da Crise Escolar. Revista Ciência \& Educação, Bauru, v. 12, n. 2, p. 235-245, ago. 2006. Disponível em: <http://www.scielo.br/pdf/ciedu/v12n2/08.pdf>. Acesso em: 15 nov. 2008.

BARDIN, Laurence. Análise de Conteúdo. Lisboa: Edições 70, 2006. 223 p.

BATISTA, Lúcio José Carlos. Aprendizagem colaborativa mediada por computador. Revista Colabora, Campo Grande, v. 3, n. 11, jul. 2006. Disponível em: <http://www.ricesu.com.br/colabora/n11/artigos/n_11/pdf/id_04.pdf>. Acesso em: 13 jan. 2008.

BEHRENS, Marilda Aparecida. A prática pedagógica e o desafio do paradigma emergente. Revista brasileira de estudos pedagógicos, Brasília, v. 80, n. 196, p. 383-403, set./dez.

\footnotetext{
${ }^{92}$ De acordo com a Associação Brasileira de Normas Técnicas. NBR 6023.
} 
1999. Disponível em: <http://www.emaberto.inep.gov.br/index.php/RBEP/article/view/167/0>. Acesso em: 15 jan. 2008.

BELLO, Silvia. Ideas previas y cambio conceptual. Educación Química, Del. Coyoacán, v. 15, n. 3, p. 210-217, jul. 2004. Disponível em: $<$ http://www.fio.unicen.edu.ar/usuario/arocha/p5-

0/index_archivos/BIBLIOGRAFIA/2004EQ210217.pdf>. Acesso em: 20 jan. 2008.

BELTRAN, Nélson Orlando. PROQUIM: uma alternativa contra a memorização no ensino de química. Revista de Ensino de Ciências, São Paulo, n. 19, p. 27-30, out. 1987. Disponível em: <http://www.cienciamao.if.usp.br/dados/rec/_proquimnelsonorlandobelt.arquivo.pdf>. Acesso em: 25 jan. 2009.

BORTOLAI, Michele Marcelo Silva; REZENDE, Daisy de Brito. Alteração do conceito de transformação em aulas de Química. In: REUNIÃO ANUAL DA SOCIEDADE BRASILEIRA DE QUÍMICA, 30., 2006, Águas de Lindóia. Resumos da 30ª Reunião anual da Sociedade Brasileira de Química. Águas de Lindóia: Centro de Convenções do Hotel Monte Real Resort, 2006. Disponível em: <http://sec.sbq.org.br/eventos/30rasbq/resumos/T1459-1.pdf>. Acesso em: 21 out. 2008.

BOSQUILHA, Gláucia Elaine; VIDOTTI, Isaura Maria Gonçalves; PITOMBO, Luis Roberto de Moraes; MARCONDES, Maria Eunice Ribeiro; BELTRAN, Maria Helena Roxo; PORTO, Paulo Alves; ESPERIDIÃO, Yvone Mussa. Interações e transformações: Química Ensino Médio: Livro do Aluno: Guia do Professor. 4ª ed. São Paulo: Editora da Universidade de São Paulo. 1998. 200 p.

BRASIL. Ministério da Educação e do Desporto. Secretaria de Educação Fundamental. Parâmetros Curriculares Nacionais: ensino médio. Brasília, DF, 1999. 360 p.

BULWIK, Marta. La evaluación de los aprendizajes y el portafolios. Educación Química. Del. Coyoacán, v. 15, n. 2, p. 104-107, abr. 2004. Disponível em: <http://dialnet.unirioja.es/servlet/articulo?codigo=935547>. Acesso em: 07 set. 2008.

CALDAS, Roseli Fernandes Lins; HÜBNER, Maria Martha Costa. O desencantamento com o aprender na escola: o que dizem professores e alunos. Revista Psicologia: Teoria e Prática, São Paulo, v. 3, n. 2, p. 71-82, jul./dez. 2001. Disponível em: <http://www3.mackenzie.br/editora/index.php/ptp/article/viewFile/1091/804>. Acesso em: 23 mai. 2007.

CARDOSO, Sheila Pressentin; COLINVAUX, Dominique. Explorando a motivação para estudar química. Química Nova. São Paulo, v. 23, n. 3, p. 401-404, São Paulo, mai./jun. 2000. Disponível em: <http://www.scielo.br/pdf/qn/v23n3/2827.pdf>. Acesso em: 02 nov. 2006.

CARVALHO, Anna Maria Pessoa de Carvalho. Ensino de Ciências: unindo a pesquisa e a prática. São Paulo: Pioneira Thomson Learning, 2004. 154 p. 
CARVALHO, Ingrid; MION, Rejane Aurora. Como incorporar a cultura científica e tecnológica via ensino médio?. In: CONGRESSO LUSO-AFRO-BRASILEIRO DE CIÊNCIAS SOCIAIS, 8., 2004, Coimbra. Anais do VII Congresso Luso-Afro-Brasileiro de Ciências Sociais: a questão social do novo milênio. Coimbra: Universidade de Coimbra, 2004. Disponível em: <http://www.ces.uc.pt/lab2004/pdfs/IngridCarvalho.pdf>. Acesso em: 13 dez. 2008.

CASTILHO, Dalva Lúcia; SILVEIRA, Kátia Pedroso; MACHADO, Andréa Horta. As aulas de Química como espaço de investigação e reflexão. Química Nova na Escola: química como investigação e reflexão, São Paulo, n. 9, p. 14-17, mai. 1999. Disponível em: <http://qnesc.sbq.org.br/online/qnesc09/relatos.pdf>. Acesso em 11 out. 2007.

CASTRO, A. A. D. Educação e Epistemologia Genética. In: MANTOVANI DE ASSIS, O. Z. et al. (Org.). Um olhar construtivista sobre a educação. Campinas: Vieiras, 2001. p. 9 -20.

CIRINO, Marcelo Maia. Considerações sobre práticas de sala-de-aula no ensino de ciências: uma abordagem comparativa. Revista Diálogo Educacional, Curitiba, v. 6, n.18, p. 169181, mai./ago. 2006. Disponível em: <http://www2.pucpr.br/reol/index.php/DIALOGO?dd1=586\&dd99=view>. Acesso em: 27 set. 2009.

COLL, César; SOLÉ, Isabel. Os professores e a concepção construtivista. In: COLL, César; MARTÍN, Elena; MAURI, Teresa; MIRAS, Mariana; ONRUBIA, Javier; SOLÉ, Isabel; ZABALA, Antoni. O construtivismo na sala de aula. São Paulo: Editora Ática. 2002, 221 p.

COSTA, Sayonara Salvador Cabral da; MOREIRA, Marco Antonio. A resolução de problemas como um tipo especial de aprendizagem significativa. Caderno Brasileiro de Ensino de Física, Florianópolis, v. 18, n. 3, p. 278-297, dez. 2001. Disponível em: <http://www.periodicos.ufsc.br/index.php/fisica/article/view/6663/6134>. Acesso em: 27 set. 2008.

CUEVAS, German Enrique Cares; JUNIOR, Iterlandes Machado; SOUZA, José Carlos Leandro de Souza; SOUZA, Vitor Hugo Rodrigues de. Ação colaborativa no Ensino de Química. In: CONGRESSO BRASILEIRO DE EXTENSÃO ỦNIVERSITÁRIA, 2., 2004, Belo Horizonte. Anais do $2^{\circ}$ Congresso Brasileiro de Extensão Universitária. Belo Horizonte: UFMG, 2004. Disponível em: <http://www.ufmg.br/congrext/Educa/Educa23.pdf>. Acesso em: 13 fev. 2008.

CYRINO, Eliana Goldfarb; TORALLES-PEREIRA, Maria Lúcia. Trabalhando com estratégias de ensino-aprendizado por descoberta na área da saúde: a problematização e a aprendizagem baseada em problemas. Cad. Saúde pública, Rio de janeiro, v. 20, n. 3, p. 780-788, mai-jun. 2004. Disponível em: <http://www.scielo.br/pdf/csp/v20n3/15.pdf>. Acesso em: 13 dez. 2008. 
DANTAS, Heloysa. A afetividade e a Construção do sujeito na psicogenética de Wallon. In: TAILLE, Y.; OLIVEIRA, M. K.; DANTAS, H. Teorias Psicogenéticas em Discussão. São Paulo: Summus, 1992. $117 \mathrm{p}$.

DEL PRETTE, Zilda A. Pereira; DEL PRETTE, Almir; GARCIA, Fabíola Alvares; SILVA, Alessandra Turini Bolsoni; PUNTEL, Ludmila Palucci. Habilidades sociais do professor em sala de aula: um estudo de caso. Psicologia Reflexão Crítica, Porto Alegre, v. 11, n. 3, p. 591-603, $1998 . \quad$ Disponível em: <http://www.scielo.br/scielo.php?script=sci_arttext\&pid=S0102-

$79721998000300016 \&$ Ing=pt\&nrm=iso>. Acesso em: 07 fev. 2008.

DINIZ, José Péricles. Leitura e Escrita (do impresso ao digital) como práticas sociais formadoras de cidadania. Diálogos possíveis. Salvador, ano 6, n. 2, p. 131-144, jul/dez. 2007. Disponível

em: <http://www.faculdadesocial.edu.br/dialogospossiveis/artigos/11/08.pdf>. Acesso em: 15 jul. 2008.

ELEUTÉRIO, Maria Helena Bueno. Afetividade e emoção: memorial de formação. 2005. 34f. Trabalho de conclusão de curso. Faculdade de Educação. Universidade de Campinas, Campinas, dez. 2005. Disponível em: <http://libdigi.unicamp.br/document/?code=20826>. Acesso em: 11 jul. 2009.

FERREIRA, Deller James; SANTOS, Gilberto Lacerda dos. Mediação do professor na aquisição e produção colaborativa do conhecimento na Web. Ciências \& Cognição, Rio de Janeiro, v. 13, n. 3, p. 288-299, dez. 2008. Disponível em: <http://www.cienciasecognicao.org/pdf/v13_3/m318298.pdf>. Acesso em: 15 jul. 2009.

FERREIRA, Sandra Patrícia Ataíde; DIAS, Maria da Graça Bompastor Borges. A escola e o Ensino da Leitura. Psicologia em Estudo, Maringá, v. 7, n. 1, p. 39-49, jan./jun. 2002. Disponível em: <http://www.scielo.br/pdf/pe/v7n1/v7n1a05.pdf>. Acesso em: 17 jul. 2009.

FLOR, Cristhiane Cunha. A necessidade do estabelecimento de uma linguagem química na visão de estudantes do ensino médio. In: ENCONTRO DE QUÍMICA DA REGIÃO SUL, 16. SOCIEDADE BRASILEIRA DE QUÍMICA SUL, 16., 2008, Blumenau. Resumos do XVI Encontro de Química Sul. Blumenau: FURB, 2008. Disponível em: <http://www.furb.br/temp_sbqsul/_app/_FILE_RESUMO_CD/531.pdf>. Acesso em: 27 jul. 2009.

GALÃO, Olívio Fernandes; BUENO, Eliana Aparecida Silicz; BORSATO, Dionisio; ALMEIDA, Flaveli Aparecida de Souza; MOREIRA, Ivanira; MARTINS, Antonio. A química no ensino médio tendo "detergente" como tema motivador. Semina: Ciências Exatas e Tecnológicas, Londrina, v. 24, p. 85-92, dez. 2003. Disponível em: <http://www.uel.br/revistas/uel/index.php/semexatas/article/viewFile/1549/1299>. Acesso em: 28 ago. 2008.

GALIAZZI, Maria do Carmo; GONCALVES, Fábio Peres. A natureza pedagógica da experimentação: uma pesquisa na licenciatura em química. Química Nova, São Paulo, v. 
27, n. 2, p. 326-331. mar./abr. 2004. Disponível em: <http://www.scielo.br/pdf/qn/v27n2/19283.pdf>. Acesso em: 25 fev. 2008.

GALVÃO, Izabel; Henri Wallon: uma concepção dialética do desenvolvimento infantil. $17^{a}$ ed. Petrópolis: Vozes, 2008. 136 p.

GAMA, Elizabeth Maria Pinheiro; LUCAS, Liney Orlandina; SALVIATO, Maria de Lourdes; JESUS, Denise Meyrelles de; CARVALHO, Janete Magalhães; DOXSEY, Jaime Roy. As percepções sobre a causalidade do fracasso escolar no discurso descontente do magistério. Revista Brasileira de Estudos Pedagógicos, Brasília, v. 72, n. 172, p. 356-384, set./dez. 1991. Disponível em: <http://rbep.inep.gov.br/index.php/RBEP/article/viewFile/477/489>. Acesso em: 22 out. 2009.

GANDOLFI, Haira Emanuela; ROSSI, Adriana Vitorino. Ensinar Química no Estado de São Paulo antes e depois da LDB/96. In: ENCONTRO NACIONAL DE ENSINO DE QUÍMICA, 14., 2008, CURITIBA. Anais do XIV Encontro Nacional de Ensino de Química, Curitiba: UFPR, 2008.2 Disponível em: <http://www.quimica.ufpr.br/eduquim/eneq2008/resumos/R0034-1.pdf>. Acesso em: 21 set. 2009.

GASPAR, Alberto. O ensino informal de ciências: de sua viabilidade e interação com o ensino formal à concepção de um centro de ciências. Caderno Catarinense de Ensino de Fisica, Florianópolis, v. 9, n. 2, p. 157-163, ago. 1992. Disponível em: <http://www.periodicos.ufsc.br/index.php/fisica/article/viewFile/7493/6872>. Acesso em: 15 set. 2008.

GASPAR, Alberto; MONTEIRO, Isabel Cristina de Castro; MONTEIRO, Marco Aurélio Alvarenga. Um estudo sobre atividades experimentais de demonstração em sala de aula: proposta de uma fundamentação teórica. Enseñanza de Las Ciências, Barcelona, Número Extra. 2005.2 Disponível em: <http://ensciencias.uab.es/webblues/www/congres2005/material/comuni_orales/3_Relacion_ invest/3_3/Gaspar_615.pdf>. Acesso em: 11 nov. 2008.

GEHLEN, Simoni Tormöhlen; AUTH, Milton Antonio; AULER, Décio. Contribuições de Freire e Vygotsky no contexto de propostas curriculares para a Educação em Ciências. Revista Electrónica de Enseñanza de las Ciencias, v. 7, n. 1, p. 63-85. 2008. Disponível em: <http://www.saum.uvigo.es/reec/volumenes/volumen7/ART4_Vol7_N1.pdf> Acesso em: 19 jun. 2009.

GEROSA, M.A.; FUKS, H.; LUCENA, C.J.P. Suporte à Percepção em Ambientes Digitais de Aprendizagem Colaborativa. Revista Brasileira de Informática na Educação, Rio de Janeiro, v. 11, n. 2, nov. 2003. Disponível em: <http://www.cos.ufrj.br/ avivacqua/cscw2003/RBIE-PercepcaoAulaNet.pdf>. Acesso em: 22 out. 2009.

GIORDAN, Marcelo. O papel da experimentação no ensino de Ciências. Química Nova na Escola. São Paulo, n. 10, p. 43-49, nov. 1999. Disponível em: <http:/ 
/www.lapeq.fe.usp.br/meqvt2006/disciplina/biblioteca/artigos/qnesc10.pdf>. Acesso em: 10 jul. 2007.

GOMES, Luiz Adolfo Kangussu. O Tema Propriedades Específicas dos Materiais como um dos eixos estruturadores de um curso introdutório de química. Química Nova na Escola, São Paulo, n. 8, p. 15, nov. 1998. Disponível em: <http://qnesc.sbq.org.br/online/qnesc08/relatos.pdf>. Acesso em: 15 ago. 2007.

HAMBURGER, Amélia Império; LIMA, Elvira CA. Souza. O ato de ensinar Ciências. Em Aberto, Brasília, ano 7, n. 40, p. 13-16. Out./dez. 1988. Disponível em: <http://www.publicacoes.inep.gov.br/arquivos/\%7B9268C554-F25A-4D61-A2A7-

E1775443BE4C\%7D_\%C3\%ADndiceEmAberto_2705.pdf>. Acesso em: 10 mar. 2010.

JONASSEN, David. O uso das novas tecnologias na educação a distância e a aprendizagem construtivista. Em Aberto, Brasília, ano 16, n. 70, p. 70-88, abr./jun. 1996. Disponível em: <http://www.falemosportugues.com/ntics/pdf/pdf/Uso_novas_tecnologias_educacao_distanci a.pdf>. Acesso em: 20 out. 2009.

JUNIOR, Wilmo Ernesto Francisco; FERREIRA, Luiz Henrique; HARTWIG, Dácio Rodney. A dinâmica de resolução de problemas: analisando episódios em sala de aula. Ciências \& Cognição, Rio de Janeiro, v. 13, n. 3, p. 82-99, dez. 2008. Disponível em: <http://www.cienciasecognicao.org>. Acesso em: 20 out. 2009.

KASTRUP, Virginia. O Devir-Criança e a Cognição Contemporânea. Revista de Psicologia: Reflexão e Crítica, Porto Alegre, v. 13, n. 3, p. 373-382, 2000. Disponível em: <http://www.scielo.br/pdf/prc/v13n3/v13n3a06.pdf>. Acesso em: 19 ago. 2007.

KINALSKI, Alvina Canal; ZANON, Lenir Basso; O leite como tema organizador de aprendizagens em Química no ensino fundamental. Química Nova na Escola, São Paulo, n. $6, \quad$ p. 15-19, nov. 1997. Disponível em: <http://qnesc.sbq.org.br/online/qnesc06/relatos.pdf>. Acesso em: 21 set. 2006.

KRASILCHIK, Myriam. O Professor e o Currículo das Ciências. São Paulo: Editora Pedagógica e Universitária Ltda. 1987. 80 p.

KRASILCHIK, Myriam. Reformas e Realidade: o caso do ensino das ciências. São Paulo em Perspectiva, São Paulo, v. 14, n. 1, p. 85-93, 2000. Disponível em: <http://www.scielo.br/pdf/spp/v14n1/9805.pdf>. Acesso em: 25 out. 2008.

LABURÚ, Carlos Eduardo; CARVALHO, Marcelo de. Educação Científica: controvérsias construtivistas e pluralismo metodológico. Londrina: Eduel, 2005. 130 p.

LAKATOS, Eva Maria; MARCONI, Marina de Andrade. Metodologia Científica. São Paulo: Editora Atlas. 1983. 231 p. 
LIMA, Mark R. C.; QUARTO, Cícero C., LABIDI, Sofiane; SCHIVITZ, Ida M. M. Considerando fatores sócio-afetivos para a formação de grupos em ambientes colaborativos de aprendizagem apoiados por computador utilizando algoritmos genéticos. Scientia Interdisciplinary Studies in Computer Science, São Leopoldo, v. 19, n. 2, p. 128-143, jul./dez. $2008 . \quad$ Disponível em: <http://www.unisinos.br/publicacoes_cientificas/images/stories/pdfs_scientia/v19n2/128a143 _art05_quarto.pdf>. Acesso em: 25 jul. 2009.

LOPES, Alice Casemiro. Os parâmetros curriculares nacionais para o ensino médio e a submissão ao mundo produtivo: o caso do conceito de contextualização. Educação \& Sociedade, Campinas, v. 23, n. 80, p. 386-400, set. 2002. Disponível em: <http://www.scielo.br/pdf/es/v23n80/12938.pdf>. Acesso em: 27 dez. 2007.

LURIA, Alexandr Romanovich. Pensamento e Linguagem: as últimas conferências de Luria. Porto Alegre: Artes Médicas. 1986. 251 p.

MACHADO, Andréa Horta. Aula de Química: discurso e conhecimento. $2^{-a}$ ed., ljuí: Ed. Unijuí. 2004. 200 p.

MAGALHÃES, Mauro de Oliveira. A aprendizagem como disciplina de diálogo: implicações científicas e sociais. Rev. Estudos de Psicologia, Campinas, v. 20, n. 1, p. 37-50, jan./abr. 2003. Disponível em: <http://www.scielo.br/pdf/estpsi/v20n1/a04v20n1.pdf>. Acesso em: 15 jan. 2007.

MAZON, Antonieta B.; REZENDE, Daisy de B.; ROMANELI, Lilavate I.; MARCONDES, Maria E. R.; BELTRAN, Maria H. R.; BELTRAN, N. O.; SCHNETZLER, Roseli P. PROQUIM: Projeto de Ensino de Química para o $2^{\circ}$ Grau. Vol. I e II. Campinas: UNICAMP, 1986. 52p.

MAZON, Antonieta Bianchi. Aprendizagem de Química: Parâmetros de significação e de investigação no ensino de $2^{\circ}$ grau - Um estudo do material Instrucional do PROQUIM, 1986. 1989. 174f. Dissertação de Mestrado. Faculdade de Educação. Unicamp. Campinas. 1989.

MIGLIATO FILHO, José Roberto. Utilização de modelos moleculares no ensino de estequiometria para alunos do ensino médio. 2005. 120f. Dissertação de Mestrado. Departamento de Química. UFSCar. São Carlos, abr. 2005. Disponível em: <http://www.dominiopublico.gov.br/download/texto/cp021577.pdf>. Acesso em 15 jun. 2008.

MOLL, Luis C.; Vygotsky e a Educação: implicações pedagógicas da psicologia sóciohistórica. Porto Alegre: Artes Médicas. 1996.

MORAES, Roque; GALIAZZI, Maria do Carmo. Análise Textual Discursiva: processo reconstrutivo de múltiplas faces. Ciência \& Educação, Bauru, v. 12, n. 1, p. 117-128, 2006. Disponível em: <http://www.scielo.br/pdf/ciedu/v12n1/08.pdf>. Acesso em: 15 jun. 2008. 
MORAIS, Angelita Vieria de; MATHEUS-VALLE, José Luiz. Investigando a inserção dos "Tutoriais em Física Introdutória"no Ensino Médio. In: SIMPÓSIO NACIONAL DE ENSINO DE FÍSICA, 18., 2009, Vitória. Anais do XVIII Simpósio Nacional de Ensino de Física. Vitória: UFV, $2009 . \quad$ Disponível em: <http://www.sbf1.sbfisica.org.br/eventos/snef/xviii/sys/resumos/T0466-1.pdf>. Acesso em 10 de mar. 2009.

MOREIRA, M.A. Pesquisa em ensino: O vê epistemológico de Gowin. São Paulo: EPU. 1990. $94 \mathrm{p}$.

MOSQUERA, Juan José Mouriño; STÖBAUS, Claus Dieter. Afetividade: a manifestação de sentimentos na educação. Revistas Educação. Porto Alegre, v. 28, n. 58. p. 123-133. jan/abr. 2006. Disponível em: < http://redalyc.uaemex.mx/redalyc/pdf/848/84805807.pdf>. Acesso em 10 fev. 2008.

MÜTZENBERG, Luiz André. Trabalhos Trimestrais: uma proposta de pequenos projetos de pesquisa no Ensino de Física. 2005. 257f. Dissertação de Mestrado. Instituto de Física. UFRGS. Porto Alegre. 2005.2 Disponível em: <http://www.lume.ufrgs.br/bitstream/handle/10183/5979/000522969.pdf?sequence=1>.

Acesso em: 10 jul. 2009.

NEBIAS, Cleide. Formação dos conceitos científicos e práticas pedagógicas. Interface, Botucatu, v. 3, n. 4, p. 133-140, fev. 1999. Disponível em: $<$ http://www.scielo.br/scielo.php?script=sci_arttext\&pid=S1414-

$32831999000100011 \& \mathrm{lng}=\mathrm{es} \& \mathrm{nrm}=\mathrm{iso}>$. Acesso em: 12 nov. 2008.

NEHRING, Cátia Maria; SILVA, Cibele Celestino; TRINDADE, José Análio de Oliveira; PIETROCOLA, Maurício; LEITE, Raquel Crosara Maia; PINHEIRO, Terezinha de Fátima. As ilhas de racionalidade e o saber significativo: o ensino de ciências através de projetos. Revista Ensaio: pesquisa em ensino e ciências, Belo Horizonte, v. 2, n. 1, p. 01-18, mar. 2002. Disponível em: <http://www.fae.ufmg.br/ensaio/v2_n1/catiacibele.PDF>. Acesso em 23 nov. 2007.

OLIVEIRA, Carla Marques de; CARVALHO, Anna Maria Pessoa de. Escrevendo em aulas de Ciências. Ciência \& Educação, Bauru, v. 11, n. 3, p. 347-366, dez. 2005. Disponível em: $<$ http://www.scielo.br/pdf/ciedu/v11n3/01.pdf>. Acesso em: 20 jan. 2008.

OLIVEIRA, Iara T. de; SANTOS, Crizélia G. Bezerra; MARCONDES, Maria Eunice R. Como 0 ensino influencia na aprendizagem sobre transformações químicas. In: ENCONTRO NACIONAL DE ENSINO DE QUIMMICA, 14., 2008, Curitiba, Anais do XIV Encontro Nacional de Ensino de Química, Curitiba: UFPR, 2008. Disponível em: <http://www.quimica.ufpr.br/eduquim/eneq2008/resumos/R0208-2.pdf>. Acesso em: 16 mar. 2010. 
OLIVEIRA, Katya Luciane de; SANTOS, Acácia Aparecida Angeli dos. Compreensão em Leitura e Avaliação da Aprendizagem em Universitários. Psicologia: Reflexão e Crítica, Porto Alegre, v. 18, n. 1, p. 118-124, abr. 2005. Disponível em: http://www.scielo.br/pdf/prc/v18n1/24825.pdf. Disponível em: 03 fev. 2008.

OLIVEIRA, Marta Kohl de. O problema da afetividade em Vygotsky. In: TAILLE, Y.; OLIVEIRA, M. K.; DANTAS, $H$. Teorias Psicogenéticas em Discussão. São Paulo: Summus, $1992.117 \mathrm{p}$.

PACHECO, Décio. A experimentação no ensino de ciências. Ciência \& Ensino, Campinas, n. $2, \quad$ p. 10, jun. $1997 . \quad$ Disponível em: <http://www.fisica.ufc.br/conviteafisica/cien_ens_arquivos/numero2/p10.pdf>Acesso em: 25 mar. 2008.

PELIZZARI, Adriana; KRIEGL, Maria de Lurdes; BARON, Márcia Pirih; FINCK, Nelcy Teresinha Lubi; DOROCINSKI, Solange Inês. Teoria da Aprendizagem Significativa Segundo Ausubel. Rev. PEC, Curitiba, v. 2, n. 1, p. 37-42, jul. 2001/jul. 2002. Disponível em: $<$ http://www.bomjesus.com.br/publicacoes/pdf/revista_PEC/teoria_da_aprendizagem.pdf> Acesso em: 10 dez. 2008

PEREIRA, Joana Rodrigues Peres; DINIZ, Soely Mariano e FERREIRA, Josiane Peres. Afetividade como auxílio à aprendizagem. In: CONGRESSO DE EDUCAÇÃO UNIPAN, 1. 2007, Cascavel. Anais do I Congresso de Educação UNIPAN: Desafio da Formação Humana. Cascavel: UNIPAN, 2007. Disponível em: <http://www.unipan.br/congresso/pdf_congresso/AFETIVIDADE\%20COMO\%20AUXÍLIO\%2 OAPRENDIZAGEM.pdf>. Acesso em 20 set. 2008.

PONTES NETO, José Augusto da Silva. Teoria da Aprendizagem significativa de David Ausubel: perguntas e respostas. Revista Série-Estudos: Periódicos do Mestrado em Educação da UCDB, Campo Grande, n. 21, p. 117-130, jan./jun. 2006.

POZO, Juan Ignacio. A aprendizagem e o ensino de fatos e conceitos. In: COLL, César. et al. Os conteúdos na reforma: ensino e aprendizagem de conceitos, procedimentos e atitudes. Tradução Beatriz Affonso Neves. Porto Alegre: Artes Médicas, 2000. 177 p.

RAMOS, Daniela Karine. Possibilidades e formas de colaboração: um estudo com alunos do Ensino Fundamental. Revista Novas Tecnologias na Educação: CINTE-UFRGS. Porto Alegre, v. 5, $\mathrm{n} \quad 2$, dez. 2007,. $\quad$ Disponível $\quad$ em: <http://www.cinted.ufrgs.br/ciclo10/artigos/5bDaniela.pdf>. Acesso em: 10 dez. 2008

RATNER, Carl. A psicologia sócio-histórica de Vygotsky: aplicações contemporâneas. Tradução Lólio Lourenço de Oliveira. Porto Alegre: Artes Médicas, 1995. 318 p.

RIBEIRO, Célia. Metacognição: um apoio ao processo de aprendizagem. Revista Psicologia: Reflexão e Crítica, Porto Alegre, v. 16, n. 1, 2003, p. 109-116. Disponível em: http://www.scielo.br/pdf/prc/v16n1/16802.pdf. Acesso em: 15 set. 2007. 
RIBEIRO, Marinalva L.; JUTRAS, France. Representações sociais de professores sobre afetividade. Revista Estudos de Psicologia, Campinas, v. 23, n. 1, mar. 2006, p. 39-45, Disponível em: <http://pepsic.bvs-psi.org.br/scielo.php?script=sci_arttext\&pid=S0103166X2006000100005\&lng=es\&nrm=iso>. Acesso em 16 nov. 2007.

RIBEIRO, Roberto Ananias; FONSECA, Francine Souza Alves Fonseca; SILVA, Patrícia Nery. Aula prática como motivação para estudar Química e o perfil de estudantes do 3ำ ano do Ensino Médio em Escolas Públicas e Particulares de Montes Claros/MG. Unimontes Científica. Montes Claros, v. 5, n. 2, jul./dez. 2003, p. 1-7. Disponível em: <http://www.unimontes.br/unimontescientifica/revistas/Anexos/artigos/revista_v5_n2/word\%2 0e\%20pdf/14\%20artigos_aula.pdf> Acesso em: 25 fev. 2008.

ROCHEX, Jean-Yves. A noção de relação com o saber: convergências e debates teóricos. Revista Educação e Pesquisa, São Paulo, v. 32, n. 3, p. 637-650, set./dez. 2006. Disponível em: <http://www.scielo.br/pdf/ep/v32n3/a14v32n3.pdf> Acesso em: 20 fev. 2008.

ROSA, Maria Inês de Freitas Petrucci S.; SCHNETZLER, Roseli Pacheco. Sobre a importância do conceito transformação química no processo de aquisição do conhecimento químico. Revista Química Nova na Escola, São Paulo, n. 8, nov. 1998. p. 31-35. Disponível em: <http://qnesc.sbq.org.br/online/qnesc08/pesquisa.pdf>. Acesso em: 02 mar. 2007.

ROSA, Maria Inês de Freitas Petrucci; QUINTINO, Tânia Cristina de Assis; ROSA, Derval dos Santos. Possibilidades de Investigação-Ação em um programa de formação continuada de professores de Química. Revista Química Nova na Escola. São Paulo, n. 14, nov. 2001, p. 637-650. Disponível em: <http://qnesc.sbq.org.br/online/qnesc14/v14a08.pdf>. Acesso em: 15 jan. 2009

ROSA, Maria Inês Petrucci; TOSTA, Andréa Helena. O lugar da Química na escola: movimentos constitutivos da disciplina no cotidiano escolar. Ciência \& Educação, Bauru, v. 11, n. 2, 2005 p. 253-262. Disponível em: <http://www.scielo.br/pdf/ciedu/v11n2/07.pdf>. Acesso em: 03 abr. 2008.

SANTANA, Samuel Nunes de; TEIXEIRA, Elder Sales. Um estudo de caso sobre as implicações da abordagem Ausubeliana no ensino de Física. Sitientibus Série Ciências Físicas. Feira de Santana, dez. 2005, p. 63-71. Disponível em: <http://www2.uefs.br/depfis/sitientibus/vol1/Elder_Main-SPSS.pdf> Acesso em: 25 abr. 2008.

SANTOS, Sandra Maria de Oliveira. Critérios para avaliação de livros didáticos de Química para o Ensino Médio. 2006. 234f. Dissertação de Mestrado. Instituto de Física, Instituto de Química. Brasília: 2006. Disponível em $<\mathrm{http}: / /$ bdtd.bce.unb.br/tedesimplificado/tde_busca/arquivo.php?codArquivo=1460>. Acesso em: 15 jul. 2009. 
SANTOS, André Nosseis dos; QUADROS, Ana Luiza de. Há evolução conceitual sobre transformações químicas a partir da discussão de modelos sobre fenômenos? In: ENCONTRO NACIONAL DE ENSINO DE QUÍMICA, 14., 2008, Curitiba, Anais do XIV Encontro Nacional de Ensino de Química, Curitiba: UFPR, 2008. Disponível em: $<$ http://www.quimica.ufpr.br/eduquim/eneq2008/resumos/R0110-1.pdf>. Acesso em: 16 mar. 2010.

SÃO PAULO. Proposta Curricular do Estado de São Paulo: Química, $1^{\text {a }}$ ed. Coord. Maria Inês Fini; São Paulo: SEESP, 2008. Disponível em: $<$ http://www.rededosaber.sp.gov.br/contents/SIGSCURSO/sigscFront/default.aspx?SITE_ID $=25 \&$ SECAO_ID=597>. Acesso em: 24 mar. 2008.

SCHAFFER, Deise Zamboni. Representações Sociais de alunos universitários sobre o tema "Orgânico". 2007. 86f. Dissertação de Mestrado. Instituo de Física, Química, Biociências e Faculdade de Educação. Universidade de São Paulo. São Paulo. 2007. Disponível em: <http://www2.if.usp.br/ cpgi/DissertacoesPDF/Deise_Zamboni_Schaffer.pdf>. Acesso em: 24 jun. 2008.

SCHMIDT, Leide Mara; RIBAS, Mariná Holzmann; CARVALHO, Marlene Araujo de. A prática pedagógica como fonte de conhecimento. Revista Olhar de Professor, Ponta Grossa, out. 1998, v. 1, n. 1, p. 9-23. Disponível em: <http://www.revistas.uepg.br/index.php?journal=olhardeprofessor\&page=article\&op=viewFile \&path\%5B\%5D=842\&path\%5B\%5D=651>. Acesso em: 17 fev. 2007.

SCHNETZLER, Roseli P. A pesquisa em ensino de Química no Brasil: conquistas e perspectivas. Química Nova. São Paulo, mai. 2002, v. 25, suplemento 1, p.14 - 24. Disponível em: <http://www.scielo.br/pdf/qn/v25s1/9408.pdf>. Acesso em: 21 set. 2007.

SCHNETZLER, Roseli P. A Pesquisa no ensino de Química e a importância da Química Nova na Escola. Química Nova na Escola. São Paulo, nov. 2004, n. 20, p. 49-54. Disponível em: <http://qnesc.sbq.org.br/online/qnesc20/v20a09.pdf>. Acesso em: 13 fev. 2007.

SCHNETZLER, Roseli P. Construção do conhecimento e Ensino de Ciências. Revista Em Aberto, Brasília, jul./set. 1992, ano 11, n. 55, p. 17-21. Disponível em: <http://www.rbep.inep.gov.br/index.php/emaberto/article/viewFile/813/731>. Acesso em: 27 nov. 2008.

SHAFFER, David R. Psicologia do Desenvolvimento: infância e adolescência. São Paulo: Pioneira Thomson Learning. 2005. 627 p.

SICCA, Natalina Aparecida Laguna. Prática de Ensino de Química: um programa em construção. Revista Química Nova, São Paulo, 1993, v. 16, n. 6, p. 586-588. Disponível em:<http://quimicanova.sbq.org.br/qn/qnol/1993/vol16n6/v16_n6_\%20(15).pdf>. Acesso em 10 mar. 2010. 
SILVA, Aparecida de Fátima; SANTOS, Daniele da Costa; SAMPAIO, Elen; HUL, Marlene Teixeira; BASSO, Regiane Priscila; MATINIAK, Vera Lucia. O ensino médio na educação brasileira: avanços e retrocessos. Revista HISTEDBR On-line, Campinas, jun. 2005, n. 18, p. 45-53. Disponível em: <http://www.histedbr.fae.unicamp.br/art05_18.pdf>. Acesso em: 11 mai. 2008.

SILVA, Sebastião Franco da; BELTRAN NUNEZ, Isauro. O ensino 'pr problemas e trabalho experimental dos estudantes: reflexões teórico-metodológicas. Química Nova. São Paulo, nov./dez. 2002, v. 25, n. 6b, p. 1197-1203. Disponível em: <http://www.scielo.br/pdf/qn/v25n6b/13138.pdf>. Acesso em: 27 fev. 2008.

SLOMP, Josi; FISCHER, Julianne. Formando leitores por meio do desenvolvimento da linguagem verbal. Revista de divulgação técnico-científica do ICPG. Blumenau, jul./dez. 2006, v. 3, n. 9, p. 99-103. Disponível em: <www.icpg.com.br/hp/revista/download.exec.php?rpa_chave=16b4bf61461ec647ff34>. Acesso em: 12 mar. 2008.

TAILLE, Y.; OLIVEIRA, M. K.; DANTAS, H. Teorias Psicogenéticas em Discussão. São Paulo: Summus, 1992. $117 \mathrm{p}$.

TAVARES, Romero. Aprendizagem significativa. Revista Conceitos. Paraíba, jun. 2003/ jun. 2004, v. 5, n. 10, p. 55-60. Disponível em: <http://www.fisica.ufpb.br/ romero/pdf/2004AprendizagemSignificativaConceitos.pdf>. Acesso em: 15 out. 2007.

TITONI, Milena; DEL PINO, José Cláudio. Explorando Conceitos Químicos na Atividade Experimental Teor de Álcool na Gasolina. In: ENCONTRO NACIONAL DE ENSINO DE QUÍMICA, 14., 2008, Curitiba. Anais eletrônicos do XIV Encontro nacional de ensino de Química. Curitiba: UFPR, $2008 . \quad$ Disponível em: $<\mathrm{http}: / /$ www.quimica.ufpr.br/eduquim/eneq2008/resumos/R0490-1.pdf>. Acesso em: 20 jan. 2009

TREVISAN, Tatiana Santini. MARTINS, Pura Lúcia Oliver. A prática pedagógica do professor de química: possibilidades e limites. UNIrevista. São Leopoldo, abr. 2006, v. 1, n. 2, $\quad$ p. 1-12. Disponível em: <http://www.unirevista.unisinos.br/_pdf/UNIrev_Trevisan_e_Martins.pdf>. Acesso em: 15 mai. 2008.

ULLER, Waldir. Afetividade e cognição no ensino médio: a desconstrução do racionalismo pedagógico. 2006. 125f. Dissertação de Mestrado. Setor de Ciências Humanas, Letras e Artes. UEPG. Ponta Grossa, 2006. Disponível em: <http://www.bicentede.uepg.br/tde_busca/arquivo.php?codArquivo=13 >. Acesso em: 20 mai. 2008.

VASCONCELOS, Alexandra Alves de; SILVA, Ana Carolina Guimarães da; MARTINS, Joseane de Souza; Soares, Lupércia Jeane. A presença do diálogo na relação professor aluno. In: COLÓQUIO INTERNACIONAL PAULO FREIRE, 5., 2005, Recife. V Colóquio 
Internacional Paulo Freire, Recife: UFPE, 2005, p. 1-12. Disponível em: <http://paulofreire.org.br/pdf/comunicacoes_orais/A\%20PRESENÇA\%20DO\%20DIÁLOGO\% 20NA\%20RELAÇÃO\%20PROFESSOR-ALŪNO.pdf>. Acesso em: 11 jul. 2008.

VASCONCELOS, Mário Sérgio. Afetividade na escola: alternativas teóricas e práticas. Educação \& Sociedade, Campinas, mai./ago. 2004, v. 25, n. 87, p. 616-620. Disponível em: <http://www.scielo.br/pdf/es/v25n87/21472.pdf> Acesso em: 01 mai. 2007.

VEIGA, Mariane Teresinha Zanotto da; WEIDUSCHAT, Iris. A afetividade no processo ensino-aprendizagem. Revista de divulgação técnico-científica do ICPG, Blumenau, jul./set. 2004, v. 2, n. 6, p. 19-22. Disponível em: <www.icpg.com.br/hp/revista/download.exec.php?rpa_chave=16b4bf61461ec647ff34> Acesso em: 20 fev. 2008.

VIGOTSKI, Lev Semenovitch. Pensamento e Linguagem. 3aㅗ ed. São Paulo: Martins Fontes 2005. 224 p.

VYGOTSKY, L. S. A formação social da mente: o desenvolvimento dos processos psicológicos superiores. São Paulo: Martins Fontes, 1991. 220 p.

WEIGERT, Célia; VILLANI, Alberto; FREITAS, Denise de. A interdisplinaridade e o trabalho coletivo: análise de um planejamento coletivo. Ciência \& Educação, Bauru, 2005, v. 11, n. 1, p. 145-164. Disponível em: <http://www.scielo.br/pdf/ciedu/v11n1/12.pdf>. Acesso em: 17 ago. 2008. 
Anexos 


\begin{abstract}
ANEXOS
ANEXO A - Questionário referente ao processo de elaboração do PROQUIM e aplicado aos organizadores do material instrucional
\end{abstract}

ANEXO A1 - Questionário respondido pela Profa. Dra. Maria Eunice Ribeiro Marcondes

\title{
1. Como se formou o grupo que escreveu o PROQUIM?
}

O grupo foi formado pela Profa. Roseli Schnetzler. Como eu tinha interesse em ensino e já conhecia a Roseli, fui convidada a integrar o grupo.

\section{O que levou o grupo a escrever o PROQUIM?}

A Profa. Roseli trabalhava na faculdade de Educação da Unicamp, e lá foi amadurecendo a idéia de escrever um projeto de ensino com características diferentes dos materiais tradicionais, voltado para uma aprendizagem mais significativa da Química.

\section{Com que intenção o PROQUIM foi escrito?}

De oferecer ao professor do ensino médio uma alternativa ao processo educativo, oferecendo um material que tratava os conteúdos de maneira a priorizar a formação de conceitos pelo aluno, desenvolvendo habilidades cognitivas de ordens superiores à memorização.

\section{Quais foram as dificuldades encontradas ao escrevê-lo?}

Elaborar material didático não é um processo fácil, requer não apenas habilidades escritoras, como também conhecimentos específicos e clareza nos objetivos que se quer alcançar. Passar as idéias para o papel é um processo complexo. $O$ trabalho em equipe também não é simples de fazer. Lidar com diferenças pessoais, conceituais e outras é enriquecedor, mas torna o processo de elaboração mais demorado.

\section{Quais foram as impressões encontradas após escrevê-lo?}

À época em que foi escrito, o material representava (como representa até hoje) um avanço na abordagem dos conteúdos. Foi um desafio muito bom, o trabalho no grupo também foi muito bom, frutífero e agradável. 
6. Vocês encontraram dificuldades ou limitações ao aplicá-lo em sala de aula?

Eu não o apliquei em sala de aula. Mas os relatos de professores que o fizeram, apontam dificuldades de desenvolver a metodologia sugerida, o tempo que as atividades levavam (estavam acostumados a "correr" com a matéria"), a falta de laboratório.

7. Entre vocês escritores e aplicadores do PROQUIM, qual era a condição social dos alunos onde se aplicava o material?

Não tenho dados.

8. Vocês têm conhecimento de outros professores da rede pública ou particular de ensino que trabalharam ou ainda trabalham aplicando o PROQUIM?

Hoje não saberia dizer.

\section{Quais são os resultados obtidos por estes professores?}

10. Porque o material não terminou de ser escrito e editado?

A Profa. Schnetzler se afastou para fazer seu doutorado fora do país, passando vários anos fora. Também, provavelmente, os membros do grupo passaram a ter outras prioridades.

11. Vocês têm alguma mensagem para deixar aos professores que trabalham ou desejam trabalhar com este material?

Eu sugiro que cada professor procure conhecer o Proquim e outros materiais que representam alternativas mais significativas para o processo de ensino-aprendizagem, que os avalie, procurem extrair o que eles têm de "bom" para a prática docente de cada um, e que não tenham medo de arriscar mudar. O ensino e a aprendizagem de Química precisam ser mais significativos na construção de uma sociedade mais democrática, em que muitos se sintam capazes e tenham conhecimentos para emitir opiniões, julgar e agir com base, também, em conhecimentos escolares. 
ANEXO A2 - Questionário respondido pela Profa. Dra. Lilavate Izapovitz Romanelli

\section{Como se formou o grupo que escreveu o PROQUIM?}

Quando eu comecei a participar do grupo, ele já estava formado. Roseli P. Schnetzler ou Eunice Marcondes podem responder com precisão como ele se formou, suponho.

\section{O que levou o grupo a escrever o PROQUIM?}

Também cabe a elas (questão 1) responder.

\section{Com que intenção o PROQUIM foi escrito?}

Foi escrito para se tornar mais uma proposta de ensino para o ensino médio de Química com as características de ser construtivista, baseada em experimentos de descoberta dirigida e favorecendo trabalho em grupo. Além disso, buscava superar o ensino tradicional, que massacrava os alunos com um excesso de conceitos prontos e desprovidos de significado para a vida do aluno.

\section{Quais foram as dificuldades encontradas ao escrevê-lo?}

A equipe era composta por professores de cidades diferentes e, portanto, instituições e funções diferentes. O esforço para manter os encontros regulares e freqüentes foi muito grande. Faltou, então, tempo para que as propostas escritas fossem avaliadas (dentro da equipe) e revistas, além de serem testadas junto a alunos de ensino médio. Não houve recursos específicos para pagar aos professores para esse trabalho. O trabalho era voluntário.

\section{Quais foram as impressões encontradas após escrevê-lo?}

Quando conheci o PROQUIM ele tinha 3 capítulos. Achei-os homogêneos, interativos e coerentes. À medida que outros eram propostos, a uniformidade não foi a mesma. Aspectos e características de autorias diferentes ficaram mais evidentes. Mas, como não houve um PROQUIM final, essa impressão é do produto virtual.

\section{Vocês encontraram dificuldades ou limitações ao aplicá-lo em sala de aula?}

Eu tive grande resistência dos colegas de minha escola (Colégio Técnico da UFMG). A opinião dos colegas era de que seria muito arriscado trabalhar com uma proposta tão diferente e "com pouco conteúdo", dentre outras coisas. Pude aplicá-lo em duas das sete turmas de primeiro ano que tínhamos. Os alunos adoraram, apesar de que alguns 
questionavam o fato de não terem o mesmo programa das outras turmas. Assim, temiam não "ver a matéria" que cairia no vestibular. No meu Colégio, os alunos que escolhessem cursos técnicos que não fossem Química ou Biologia não teriam mais aulas de Química. Não tive problema com as condições práticas, pois preparei um ambiente no qual pude trabalhar experimentos em grupo, um laboratório-sala. Como o Colégio dispunha facilmente de reagentes, vidraria, etc, não precisei improvisar muito. Apliquei o PROQUIM literalmente por um ano. Em vista da dificuldade de completá-lo (trabalho de elaboração da equipe original) decidi formular uma outra proposta de ensino, apoiada nas idéias metodológicas do PROQUIM. Com um esforço enorme, eu e uma colega formulamos uma estratégia na qual a participação dos alunos durante as atividades foi fundamentando o conteúdo de textos que completavam os experimentos. A proposta tomou forma e foi adotada por todas as turmas do primeiro ano do Colégio. Por alguns anos assim ficou, melhorando aqui e ali. Quando novidades mais contextualizadas foram surgindo, outra proposta foi adotada, sem que as bases daquela e do PROQUIM se perdessem.

\section{Entre vocês escritores e aplicadores do PROQUIM, qual era a condição social dos alunos onde se aplicava o material?}

Apliquei-o em uma escola pública. O Colégio selecionava alunos com critérios que favorecia a entrada de um grande percentual de alunos de baixa renda familiar.

\section{Vocês têm conhecimento de outros professores da rede pública ou particular de ensino que trabalharam ou ainda trabalham aplicando o PROQUIM?}

Sim. Principalmente na rede privada.

\section{Quais são os resultados obtidos por estes professores?}

Foram professoras que tiveram apoio das coordenações de ensino dessas escolas. Seus alunos aceitaram muito bem a proposta e manifestavam muito o gosto pelas aulas e pela aprendizagem.

\section{Porque o material não terminou de ser escrito e editado?}

O projeto oficial que financiaria a sua publicação terminou e foi ficando impraticável manter as reuniões de trabalho com a equipe organizada.

11. Vocês têm alguma mensagem para deixar aos professores que trabalham ou desejam trabalhar com este material? 
Já houve muitas mudanças nos materiais de ensino. Propostas com bases teóricas mais atualizadas já existem. Grupos diversos produziram outros materiais fundamentados em um contexto mais moderno. Bons materiais de apoio (textos, propostas ou livros) são importantes e fundamentais. Mas, a conscientização dos professores sobre os processos de ensino e aprendizagem, sob os inúmeros pontos de vista (social, psicológico, de linguagem, pedagógico, por exemplo) é mais importante. Não vejo sentido em usar, tal como já existiu, o material chamado PROQUIM.

Lilavate Izapovitz Romanelli

Belo Horizonte

Agosto/2008 
ANEXO B - Capítulos do PROQUIM utilizados na pesquisa

ANEXO B1 - Capítulo 1 do PROQUIM.

CAPÍTULO I - O QUE É UMA REAÇÃO QUÍMICA?

TEXTO 1-1

A QUIIMICA É VELHA?

Em épocas remotas, nossos antepassados do tempo das cavernas ainda não sabiam explicar quase nada sobre as transformações que ocorriam no mundo material por falta de um conjunto de conhecimentos organizados. Naquela época, algum destes nossos antepassados deve ter-se assustado muito quando viu o fogo pela primeira vez. Possivelmente imaginou que fosse a manifestação do poder de algum deus. No entanto, nosso antepassado aprendeu a utilizar o fogo em seu benefício, embora, provavelmente, tenha se queimado várias vezes. Mas ... valeu, já que ele deve também ter descoberto o churrasco! Este nosso antepassado pode ser considerado o pioneiro entre os estudantes das transformações químicas.

Conhecer o fogo e dominá-lo foi muito importante: o fogo afugentava animais, iluminava e aquecia as cavernas, permitia cozinhar alimentos e construir recipientes de barro. Como os nossos antepassados aprenderam a produzir o fogo, não precisavam mais esperar que thes fosse enviado através dos raios. O domínio do fogo provocou uma transformação de costumes, trazendo vários benefícios. Afinal um churrasco de mamute era muito mais gostoso do que mamute cru!

Assim como os nossos antepassados aprenderam a produzir e a utilizar o fogo, outros conhecimentos foram sendo acumulados e utilizados para atender as necessidades básicas dos seres humanos. Cada nova descoberta propiciava uma supremacia do homem sobre os animais. Às vezes, infelizmente, de uns homens sobre outros homens. A primeira nação que aprendeu a forjar o ferro deve ter imposto sua supremacia militar sobre outras nações. Por exemplo, Júlio César, imperador romano, não entendia porque seus inimigos, os bretões, retiravam-se dos combates periodicamente. Só depois de algum tempo ele descobriu que os bretões precisavam desentortar suas espadas, já que ainda não haviam descoberto o aço este conhecimento, que os romanos dominavam, não havia sido divulgado para outros povos. 
Hoje em dia o mundo se transforma muito mais rapidamente do que em outras épocas. Quando nossos bisavós tinham a idade que temos hoje o homem nem sonhava em ir à Lua, não conhecia a bomba atômica, a Coca-Cola ou a televisão. Certamente o mundo transformou-se muito desde então. Todavia, uma pessoa que tenha vivido há um milênio não poderia afirmar o mesmo com relação ao tempo de seus bisavós. De fato, além de, freqüentemente, não conhecer muito mais coisas que seus antepassados, às vezes conheciam até menos.

Muitos conhecimentos devem ter-se perdido por falta de comunicação, tendo que ser redescobertos. Por exemplo, sabe-se hoje, que o povo da Mesopotâmia já fazia sabão há 5.000 anos. Entretanto na Grécia Antiga, em época 3000 anos posterior à da civilização que existira na Mesopotâmia, não se tomava banho. Os gregos, reconhecidos até hoje como um povo de muita sabedoria, não conheciam o sabão. Assim, limpavam-se com óleo de oliva e raspavam a sujeira com um objeto semelhante a uma faca sem corte. Sabe-se também que embora a pólvora tenha sido descoberta primeiramente na China, houve várias redescobertas em épocas e locais diferentes. Com mais um exemplo, pode-se citar o fato notório do oxigênio ter sido descoberto por Scheele na Suécia em 1722 e redescoberto dois anos depois, por Priestley, na Inglaterra.

Para evitar tais situações procura-se comunicar e divulgar as descobertas científicas pois assim, além dos eventos descritos poderem ser repetidos, contribui-se para a descoberta de novos eventos. Em síntese, há muito tempo o homem quer compreender o mundo e suas transformações; a acumulação e a divulgação do conhecimento facilitam esta compreensão do mundo e o domínio sobre a natureza.

O conhecimento químico vem sendo organizado há cerca de 200 anos, contribuindo para a explicação de vários dos aspectos envolvidos nas transformações que ocorrem na natureza como para a previsão e a descoberta de novas transformações e materiais.

Atualmente, a utilização do conhecimento químico permite ao homem a produção de medicamentos, bombas, combustíveis, plásticos, agrotóxicos e tintas, além de uma infinidade de outros materiais. Nosso antepassado das cavernas que produziu o fogo pela primeira vez nem sonharia serem possíveis processos como estes!

Muitos dos processos que ocorrem em nossa vida diária podem ser compreendidos através do estudo da química. Conhecer química é importante para compreender vários dos processos que ocorrem em nosso próprio organismo, além daqueles que estão envolvidos em nossa alimentação, na produção de matérias-primas para a confecção do nosso vestuário, na geração de energia para os nossos meios de locomoção, na obtenção de 
metais a partir dos minérios e em infinidades de outros eventos e atividades com que nos deparamos, a cada momento, diariamente.

Estão em permanente debate, atualmente, questões como a substituição de fontes não renováveis de energia através da transformação da bio-massa, a poluição ambiental ou a utilização de energia nuclear. Para compreender a abrangência destas questões e poder tomar posições críticas como cidadão também é necessário conhecer os princípios fundamentais da química. Finalmente é importante refletir sobre a necessidade de reinvidicar a utilização adequada do conhecimento químico de forma que ele possa, de fato, contribuir par a melhoria da qualidade de vida das populações.

\section{ATIVIDADE I-1 - OBSERVANDO TRANFORMAÇÕES}

As transformações que ocorrem diariamente são tantas e tão freqüentes que você talvez ainda não tenha observado cuidadosamente muitas delas. Você já pensou sobre como reconhecer a ocorrência de uma determinada transformação, por exemplo, o apodrecimento de um fruto?

Nesta atividade você será convidado a refletir sobre transformações que ocorrem na sua vida diária. Dentre elas relacione no máximo dez na tabela l-1 e anote, também, como você pôde reconhecer que se tratava de realmente de uma transformação.

Tabela I-1

\begin{tabular}{|l|l|}
\hline Transformação & Como você pôde reconhecer a transformação? \\
\hline & \\
\hline & \\
\hline & \\
\hline & \\
\hline & \\
\hline
\end{tabular}




\section{TEXTO 1-2 - RECONHECENDO TRANSFORMAÇÕES}

Na Tabela I - 1 você listou várias transformações que ocorrem na sua vida diária e indicou como pôde reconhecer sua ocorrência. É provável que você as tenha identificado através da comparação de algumas características do(s) material(is) antes e após a ocorrência da transformação. Por exemplo, podemos reconhecer o apodrecimento de um fruto comparando algumas características deste fruto antes e após o apodrecimento. De fato, características como a cor, o sabor e o cheiro são bem diferentes no fruto fresco e no fruto podre, permitindo identificar a ocorrência da transformação.

Quando se pretende estudar um fenômeno - no caso, o apodrecimento de um frutogeralmente não interessa todas as outras mudanças que se processem no universo em conseqüência deste fenômeno, mas apenas as que ocorrem numa porção delimitada do universo. A esta porção do universo que é separada para estudo dá-se o nome de sistema. No caso do estudo do apodrecimento de um fruto o apodrecimento é o fruto.

A escolha do sistema está associada ao problema que se queira abordar. Por exemplo, imagine que a questão refira-se à transformação de minério de ferro em ferro metálico. Se o problema se referir apenas à transformação em si, o sistema é apenas o minério. Se a questão abranger a proteção ambiental, o sistema é o minério mais o meio ambiente. Pode-se, também, pensar no aspecto da extração do minério. No caso o sistema seria a jazida de minério, em termos de sua extensão, facilidade de acesso, distância dos centros consumidores e assim por diante.

A cor, o cheiro, a temperatura, a massa e o volume são algumas das propriedades utilizadas para descrever um sistema. A descrição adequada de um sistema define o estado do sistema. A descrição do sistema antes da transformação define o estado inicial do sistema enquanto a descrição feita após a transformação define o estado final do sistema. Portanto, a comparação entre os estados inicial e final de um sistema fornece indicações que nos permitem reconhecer a ocorrência de transformações neste sistema.

Vamos agora, centrar nossa atenção em um tipo particular de transformação, isto é , a transformação química. As transformações químicas são, usualmente, denominadas reações químicas. O objetivo do próximo guia experimental é que você aprenda o que é uma reação química e como reconhecer as indicações de ocorrência deste tipo de transformação. 


\section{GUIA EXPERIMENTAL I - 1}

\section{O que é uma reação química?}

\section{I - Introdução.}

A cada instante que passa ocorre transformações à nossa volta. $\grave{E}$ um fruto que apodrece, é a água dos rios e dos mares que se transformam em nuvens, é o nosso próprio organismo que transforma os alimentos. Muitas destas transformações são reações químicas, muitas outras não o são. Então, como é possível identificar as reações químicas?

Como vimos no texto anterior,.é possível reconhecer a ocorrência de uma transformação qualquer - por exemplo, o enferrujamento de um portão - comparando as características do portão antes e após o enferrujamento, isto é, pela comparação dos estados final e inicial deste sistema. Mas será que esta comparação pode nos fornecer dados que permitam distinguir as reações químicas entre a infinidade de transformações que observamos no nosso dia a dia?

Neste experimento, você investigará os vários sistemas com o objetivo de identificar quais propriedades dos mesmos facilitam o reconhecimento da ocorrência de reações químicas, permitindo distingui-las de outros tipos de transformações.

\section{II - Material Necessário}

\begin{tabular}{|l|l|}
\hline 10 tubos de ensaio & 01 estante para tubos de ensaio \\
\hline 01 almofariz e pistilo & 01 espátula \\
\hline 01 pinça de madeira & 01 bico de Bunsen ou lamparina \\
\hline enxofre em pó & açúcar \\
\hline cabelo & ferro em limalhas \\
\hline ferro (prego) & magnésio em raspas \\
\hline água & solução aquosa de sulfato de cobre II \\
\hline solução aquosa de hidróxido de sódio & solução aquosa de ácido clorídrico \\
\hline solução aquosa de nitrato de chumbo II & solução aquosa de iodeto de potássio. \\
\hline
\end{tabular}




\section{III- PROCEDIMENTO}

Trabalhe com segurança:

- evite que enxofre e as soluções de sulfato de cobre II, hidróxido de sódio ou ácido clorídrico atinjam sua pele; se isto ocorrer, lave imediatamente o local afetado com bastante água;

- evite queimaduras manuseando com cuidado os materiais quentes;

- use espátula limpa para retirar os sólidos dos frascos;

- execute apenas os testes indicados explicitamente neste guia.

Em caso de acidente, aviso ao professor imediatamente.

1. Aquecimento de cabelo - execute o procedimento descrito a seguir:

a) coloque alguns fios de cabelo num tudo de ensaio limpo e seco;

b) observe e descreva na tabela de dados as características do material que constitui o sistema no estado inicial;

c) proceda ao aquecimento do material contido no tubo de ensaio seguindo as instruções dadas pelo professor;

d) observe e anote na tabela de dados as características do material após o aquecimento, isto é, as características do sistema no estado final.

2. Aquecimento de açúcar - repita o procedimento descrito no item 1 colocando uma ponta de espátula de açúcar no tubo de ensaio em vez de cabelo.

3. Aquecimento de água - repita o procedimento do item 1, colocando água no tubo de ensaio até cerca de $2 \mathrm{~cm}$ de altura, em vez de cabelo.

4. Aquecimento de enxofre em pó - repita o item 1, colocando uma ponta de espátula de enxofre em pó no tubo de ensaio, em vez de cabelo.

5. Adição de ferro a enxofre - siga o procedimento descrito abaixo:

a) observe as características do ferro em limalhas e do enxofre em pó separadamente e anote-as na tabela de dados;

b) coloque uma ponta de espátula do ferro em limalhas no almofariz; 
c) acrescente igual quantidade de enxofre em pó, triture e anote suas observações na tabela de dados;

d) reserve o material triturado para o próximo teste.

6. Aquecimento da mistura ferro-enxofre - execute o procedimento descrito a seguir.

a) transfira a mistura ferro-enxofre do almofariz para um tubo de ensaio (ou tubo de aquecimento);

b) aqueça o tubo até a incandescência;

c) anote suas observações na tabela de dados.

7. Adição de sal de cozinha à água - execute o procedimento descrito a seguir:

a) observe as características da água e do sal de cozinha e anote na tabela de dados;

b) coloque água em um tubo de ensaio limpo até cerca de $2 \mathrm{~cm}$ de altura;

c) adicione uma ponta de espátula de sal de cozinha à água contida no tubo de ensaio, agite e anote suas observações na tabela de dados.

8. Adição de ferro à solução aquosa de sulfato de cobre II - repita o procedimento descrito no item 7 substituindo os materiais utilizados anteriormente por solução de sulfato de cobre Il e um prego de ferro.

9. Adição de magnésio em raspas à solução aquosa de ácido clorídrico - repita o procedimento descrito no item 7 , substituindo os materiais utilizados anteriormente por solução de ácido clorídrico e raspas de magnésio.

10. Adição de solução aquosa de ácido clorídrico à solução aquosa de nitrato de chumbo II - execute o procedimento descrito a seguir:

a) observe as características das duas soluções separadamente e anote-as na tabela de dados;

b) coloque num tubo de ensaio limpo uma quantidade da solução de ácido clorídrico suficiente para atingir cerca de $1 \mathrm{~cm}$ de altura;

c) adicione uma quantidade igual da solução de nitrato de chumbo II e agite;

d) anote suas observações na tabela de dados. 
11. Adição de solução aquosa de iodeto de potássio à solução aquosa de nitrato de chumbo II - siga o procedimento descrito para o teste 10.

12. Adição de solução aquosa de hidróxido de sódio à solução aquosa ácido clorídrico siga o procedimento descrito para o teste 10.

13. Adição de solução aquosa de hidróxido de sódio à solução aquosa de sulfato de cobre II - siga o procedimento descrito para o teste 10.

14. Após a realização da experiência, lave e guarde todo o material utilizado.

\section{IV- TABELA DE DADOS}

Complete a tabela a seguir de acordo com as suas observações. Durante o preenchimento da tabela considere como estado final do sistema o momento em que este tenha atingido a temperatura ambiente.

\begin{tabular}{|c|c|c|c|c|c|}
\hline Teste & Sistema & Estado Inicial & \begin{tabular}{|l} 
Durante a \\
transformação
\end{tabular} & $\begin{array}{l}\text { Estado } \\
\text { final }\end{array}$ & \begin{tabular}{|l} 
Comparação \\
entre estados \\
inicial e final
\end{tabular} \\
\hline \multicolumn{6}{|l|}{1} \\
\hline \multicolumn{6}{|l|}{2} \\
\hline \multicolumn{6}{|l|}{3} \\
\hline \multicolumn{6}{|l|}{4} \\
\hline \multicolumn{6}{|l|}{5} \\
\hline \multicolumn{6}{|l|}{6} \\
\hline \multicolumn{6}{|l|}{7} \\
\hline \multicolumn{6}{|l|}{8} \\
\hline \multicolumn{6}{|l|}{9} \\
\hline \multicolumn{6}{|l|}{10} \\
\hline \multicolumn{6}{|l|}{11} \\
\hline \multicolumn{6}{|l|}{12} \\
\hline 13 & & & & & \\
\hline
\end{tabular}




\section{V- ANÁLISE DE DADOS}

1) Em qual (quais) teste(s) você observou:

a)mudança de cor

b) mudança de forma

c) liberação de gás

d) aparecimento de um novo estado físico

e) formação de precipitado (precipitado é um sólido insolúvel que se forma à partir da mistura de duas soluções)

f) mudança de odor

g) liberação de calor

h)alteração de quantidade de material

i) outras mudanças

2) Quais dos itens acima podem ser considerados como evidência (indicações de formação de novo(s) material (materiais) ?

3) Em qual (quais) critério(s) você se baseou para responder a questão 2?

4) No que você se baseou para concluir que não houve formação de novos materiais em algum (ou alguns) do(s) sistema(s)? 


\section{VI- CONCLUSÕES}

Resfriar a água líquida até a formação de gelo, rasgar uma folha de papel, fundir a taça Jules Rimet, misturar ferro e enxofre e aquecer água são exemplos de transformações que recebem o nome de transformações físicas. Por outro lado, no aquecimento do cabelo, no apodrecimento de um fruto e na adição de solução de hidróxido de sódio à solução de sulfato de cobre II, por exemplo, há ocorrência de transformações químicas. Para responder às questões seguintes, consulte também a tabela de dados e suas respostas às questões de análise de dados.

1- Em que testes você acha que houve transformações químicas? Justifique sua resposta.

2- Quando se dispara uma lâmpada de flash do tipo descartável observa-se uma intensa luminosidade e a formação de um pó branco. Por que você pode dizer que ocorreu uma reação química neste processo?

3- Quais são as principais evidências de ocorrência de reação química?

4- A obtenção do gelo a partir do resfriamento da água líquida é uma transformação física. Por que se pode fazer esta afirmação?

5- Como você pode dizer se uma transformação é física ou química?

Através da análise dos dados coletados durante o experimento, foi possível concluir que nas reações químicas há formação de novos materiais. Dentre as inúmeras transformações que podem ser observadas diariamente, inclusive aquelas que ocorrem em organismos vivos, muitas são classificadas como reações químicas. Nestas transformações o estado final do sistema é constituído por material (materiais) diferente (s) daqueles que formavam o estado inicial. $O$ fato de se formarem materiais novos é também o que distingue uma reação química de um processo físico, pois, neste, a transformação não causa formação de um ou mais materiais novos. Numa reação química, os materiais de partida são chamados de reagentes e os novos materiais formados são chamados de produtos. 


\section{VII - EXERCÍCIOS}

1- Aqueceu-se um sólido vermelho num tubo de ensaio. Depois de algum tempo de aquecimento detectou-se a liberação de um gás incolor e a formação de um líquido prateado. Pergunta-se:

a) Quais são os materiais que compõem o sistema em estudo?

b) Qual é o estado inicial do sistema?

c) Qual é o estado final do sistema?

d) Ocorreu reação química? Qual é a evidência?

2- Quando um comprimido de Sonrisal é colocado em água ocorre um processo físico ou uma reação química? Explique sua resposta.

3- Quando se aquece a água há liberação de um gás. Está ocorrendo uma reação química? Explique sua resposta.

4- Retome o quadro (Tabela I-1) construído na Atividade $\mathrm{I}-1$ e classifique as transformações ali relacionadas como reação química ou processo físico.

5- Dadas as informações a seguir, classifique-as em físicas ou químicas:

a) escurecimento de uma colher de prata

b) crescimento das unhas

c) amolecimento de um picolé de limão

d) rasgar uma folha de papel

e) cortar os cabelos

f) queima de uma acha de lenha

g) fritar um bife

h) azedar o vinho

i) ferver água

Em que critério você se baseou para proceder a esta classificação? 


\section{VIII- QUESTÕES PARA DISCUSSÃO}

1- Quando não se nota uma evidência pode-se garantir que não tenha ocorrido reação química no sistema?

2- Pode-se garantir que tenha ocorrido uma reação química num sistema considerando-se apenas a observação de evidências?

3- Por que é possível, muitas vezes, reconhecer a ocorrência de uma reação química através da observação de evidências?

TEXTO $1-3$

\section{SINTESE}

Pode-se reconhecer a ocorrência de transformações em um sistema verificando se houve alteração nas propriedades que caracterizam seu estado inicial e final. Embora, freqüentemente, estas alterações sejam perceptíveis aos nossos sentidos, em vários sistemas ocorrem transformações sem que se observem evidências. Por exemplo, quando você misturou as soluções de hidróxido de sódio e ácido clorídrico, não houve evidências observáveis embora tenha ocorrido uma transformação. Neste caso para concluir que ocorreu uma transformação é necessário recorrer a uma análise mais detalhada do sistema, utilizando instrumentos capazes de detectar as alterações ocorridas em suas propriedades.

Por outro lado, mesmo que se observem evidências, tem-se apenas uma indicação e não uma garantia sobre o tipo de transformação ocorrida. No caso da mistura de enxofre à limalha de ferro, por exemplo, ocorreu uma alteração na cor do sistema que, entretanto, não se deve à formação de um novo material.

Como se poderia ter maior certeza de que uma reação química tenha de fato ocorrido num determinado sistema?

Para responder a esta questão é necessário que se conheça outras propriedades, além das já estudadas neste capítulo (cor, cheiro, estado físico, etc.) que caracterizem melhor o estado inicial e final do sistema em estudo, permitindo caracterizar os materiais envolvidos no processo de transformação. De fato, a simples observação de uma evidência 
não permite identificar os materiais formados numa reação. Por exemplo, quando se mistura soluções aquosas de ácido clorídrico e nitrato de chumbo II forma-se um precipitado branco. Ao se juntar soluções aquosas de cloreto de bário e sulfato de sódio também se formam um precipitado branco. Esses precipitados são um mesmo material ou são materiais diferentes? Você poderá responder a esta pergunta após estudar o capítulo II. 
ANEXO B2 - Capítulo 2 do PROQUIM.

\section{CAPITULO 2}

\section{COMO SE RECONHECE UMA REAÇÃO QUÍMICA?}

No Capítulo anterior concluímos que não se pode garantir a ocorrência de uma reação química somente através da observação de evidências. Então, como podemos ter certeza de que se tenha formado um novo material?

A caracterização de um material é muito importante. Por exemplo, o medicamento conhecido como aspirina é uma mistura de um material chamado ácido acetilsalicílico com outro material chamado amido, sendo que o componente ativo é o ácido acetilsalićlico. $O$ ácido empregado na fabricação dos comprimidos é obtido através de uma reação química. É necessário, portanto, verificar as propriedades do ácido obtido para se ter certeza de que o produto da reação seja realmente o ácido acetilsalicílico e não outra substância. Através da determinação dos valores das propriedades do ácido obtido é possível, também, saber se ele está puro ou se está misturado com outros materiais, que poderiam até mesmo ser nocivos ao organismo.

As propriedades freqüentemente usadas para identificar as substâncias e distingui-las de misturas são chamadas propriedades físicas. Nas próximas experiências você vai estudar as seguintes propriedades físicas: ponto de fusão, ponto de ebulição, densidade e solubilidade. Ao final deste estudo, você será capaz de identificar uma substância pura e distingui-la de uma mistura através da determinação dessas propriedades

\section{GUIA EXPERIMENTAL II-1 \\ PONTO DE EBULIÇÃO}

\section{I - INTRODUÇÃO}

É muito fácil distinguir uma porção de água de uma porção de vinho tinto. Através de um simples olhar tem-se, imediatamente, a resposta: a água é incolor e o vinho é avermelhado. Entretanto, como se poderia diferenciar uma porção de água do mar filtrada 
de uma porção de água pura, sem experimentar o gosto? Ou, como se poderia distinguir uma porção de água de uma de álcool, sem sentir o odor?

As respostas a estas questões podem ser dadas através do estudo das propriedades desses materiais. O ponto de ebulição é uma das propriedades mais indicadas seja para distinguir, seja para identificar, líquidos. Quando se aquece um líquido até uma determinada temperatura ele começa a ferver, ou seja, entra em ebulição. A temperatura em que ocorre a ebulição de um material é chamada de ponto de ebulição.

Mas, como se poderia utilizar esta propriedade - o ponto de ebulição - para caracterizar uma substância e diferenciá-la de uma mistura?

Você pode responder a esta pergunta realizando o experimento a seguir. Neste experimento, você vai analisar a variação da temperatura com o tempo durante o aquecimento e ebulição de um líquido puro e de uma mistura. Ao final deste experimento você será capaz de:

definir o que é substância

julgar se o ponto de ebulição de uma substância pode ser considerado uma constante física;

verificar se o ponto de ebulição pode ser utilizado para caracterizar uma substância e distingui-la de uma mistura .

\title{
II - Material Necessário
}

\author{
glicerina $\quad 2$ béqueres de $100 \mathrm{~mL}$ \\ água 1 bagueta \\ 1 tripé e 1 tela de amianto \\ 1 bico de Bunsen (ou lamparina) \\ 1 termômetro de 10 a $110^{\circ} \mathrm{C}$ \\ 1 cronômetro (ou relógio com marcador de \\ segundos)
}




\section{III - Procedimento}

1. Trabalhe com segurança: Evite queimaduras, não pegando os materiais quentes com as mãos. Se a bancada do laboratório for de azulejo, não coloque materiais de vidro quentes diretamente sobre a bancada; coloque-os sobre uma tela de amianto.

2. Monte a aparelhagem necessária para aquecer a água no béquer conforme indicado na Figura II-1.

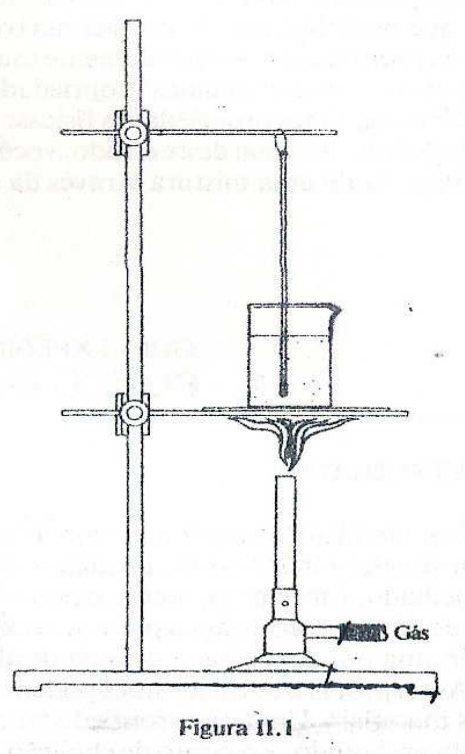

3. Coloque água no máximo até a metade do volume do béquer, conforme as instruções do seu professor.

4. Coloque o termômetro na água e inicie o aquecimento. Durante o aquecimento agite a água com o próprio termômetro, CUIDADOSAMENTE.

5. A cada 30 segundos, leia a temperatura da água e anote na tabela de dados. Assinale a temperatura em que se inicia a ebulição.

6. Após o início da ebulição, continue marcando a temperatura da água, a cada 30 segundos, durante 3 minutos.

7. Coloque no outro béquer alguns mililitros de glicerina, conforme as instruções do seu professor. Adicione água até no máximo a metade do volume do béquer e agite com a bagueta para que a glicerina se misture completamente.

8. Repita o procedimento com esta mistura de água e glicerina. 


\section{IV - Tabela de Dados}

Reproduza as tabelas abaixo no seu caderno, deixando espaço suficiente para o registro de dados.

\section{Água}

Aquecimento

\begin{tabular}{|l|l|l|}
\hline Tempo & Temperatura & \\
\hline & & \\
& & \\
& & \\
& & \\
& & \\
\hline
\end{tabular}

Glicerina + Água

Aquecimento

\begin{tabular}{|l|l|l|}
\hline Tempo & Temperatura & \\
\hline & & \\
& & \\
& & \\
& & \\
& & \\
\hline
\end{tabular}




\section{V- Análise de Dados}

1. Para analisar e comparar melhor os dados obtidos no experimento construa 0 gráfico que representa o comportamento da temperatura durante o aquecimento da água (temperatura em ordenadas $x$ tempo em abscissas). Na mesma escala, construa também o gráfico que representa o aquecimento da mistura de água e glicerina.

2. Indique, em cada gráfico, os pontos que, com certeza, correspondem à ebulição dos materiais.

3. Quais são as temperaturas em que ocorre a ebulição da água e da mistura de água e glicerina?

4. A temperatura em que ocorre a ebulição da água é constante? E da mistura, também? Explique sua resposta.

5. Compare seus dados com os valores obtidos por outras equipes que usaram outra quantidade de água e uma mistura de água com glicerina de outra proporção; responda às questões seguintes explicando suas respostas.

6. A temperatura em que ocorre a ebulição da água depende, ou não, da quantidade usada?

7. A temperatura em que se inicia a ebulição da mistura de água e glicerina depende da quantidade usada? Depende da proporção da mistura?

8. A água apresenta um único valor para o ponto de ebulição? E a mistura da água e glicerina?

\section{VI - Conclusões}

Neste experimento, você comparou o comportamento de dois líquidos incolores água e uma mistura de água e glicerina, quando aquecidos. O sistema constituído por uma única substância - água - apresentou uma temperatura definida durante a ebulição, enquanto para o sistema água e glicerina, uma mistura de duas substâncias, o processo de ebulição ocorreu numa faixa de temperatura. Além disso, na comparação do valor obtido, em seu estudo, para o ponto de ebulição da água, com os valores obtidos pelos outros colegas, você notou que estes valores eram muito próximos, isto é, iguais admitindo-se que as aparentes diferenças são devidas a erros experimentais. Considerando que a quantidade de água variou a cada grupo, você pôde dizer que o ponto de ebulição da água independe da quantidade de material. Na mistura, o ponto de ebulição não apresenta um único valor; ele varia com a mudança da proporção de água e glicerina da mistura, provocada pela 
evaporação da água: o ponto de ebulição de uma mistura não é constante. Já a água apresenta um único ponto de ebulição, independe da quantidade da amostra analisada: o ponto de ebulição da água é uma constante física. A Tabela II-1 apresenta os pontos de ebulição de algumas substâncias.

Tabela II-1: Pontos de Ebulição de algumas substâncias à pressão normal.

\begin{tabular}{|c|c|c|c|}
\hline Substância & $\frac{\text { Ponto de ebuhçã }}{{ }^{\circ} \mathrm{C}}$ & Substância & $\frac{\text { Ponto de ebuliçầ }}{{ }^{\circ} \mathrm{C}}$ \\
\hline Acetona & 56,2 & Clorofórmio & 61,74 \\
\hline Álcool etílico & 78,5 & Glicerina & $182^{20}$ \\
\hline Éter etílico & 34,51 & Nitrogênio & $-195,8$ \\
\hline Benzeno & 80,1 & Ferro & 3000 \\
\hline Metano & -164 & Alumínio & 2464 \\
\hline Álcool isopropílico & 82,4 & $\begin{array}{l}\text { Álcool } \\
\text { propílico }\end{array}$ & 97,4 \\
\hline
\end{tabular}

Considerando suas respostas às questões anteriores e a Tabela II.1, responda às questões que se seguem.

1. O ponto de ebulição é uma prioridade característica de uma substância? Explique sua resposta.

2. Como é possível diferenciar várias substâncias líquidas aparentemente iguais? Explique sua resposta.

3. Através do ponto de ebulição é possível diferenciar uma substância de uma mistura? Explique sua resposta.

4. Considerando suas conclusões neste experimento, defina substância.

5. Considerando suas conclusões neste experimento, defina mistura.

\section{VII- Exercícios}

1. A acetona, líquido incolor utilizado como solvente de algumas tintas e esmaltes, pode ser obtida através de uma reação do álcool isopropílico. Este álcool também é líquido e incolor. Como se pode ter certeza de que o produto obtido nessa reação seja realmente a acetona? Como saber se o produto é um líquido puro e não uma mistura?

2. Como é possível diferenciar água pura da água do mar filtrada sem experimentar o gosto? 
3. Faça os esboços dos gráficos obtidos para o aquecimento de duas amostras de líquidos aparentemente idênticos, considerando os seguintes casos:

a) as duas amostras são do mesmo líquido puro;

b) as duas amostras são de líquidos puros diferentes;

c) uma amostra é de um líquido puro e a outra é de uma mistura.

4. Utilizando os dados da Tabela II.1, esboce um gráfico que represente a variação da temperatura com o tempo, durante o aquecimento de uma amostra de benzeno do estado líquido até a ebulição completa.

5. Provocou-se o aquecimento de um líquido desconhecido, medindo-se a temperatura do material em intervalos de tempo de 15 segundos, até que todo o material estivesse vaporizado. Os resultados obtidos estão organizados na tabela abaixo:

\begin{tabular}{|c|c|c|c|c|c|c|c|c|c|c|c|}
\hline Tempo(s) & & 5 & 0 & 5 & 0 & 5 & 0 & 05 & 20 & 35 & 5 \\
\hline Temperatura ${ }^{\circ} \mathrm{C}$ & 5 & 4 & 3 & 1 & 9 & 1 & 2 & 2 & 1 & 3 & 0 \\
\hline
\end{tabular}

a) A partir destes dados esboce o gráfico (temperatura $x$ tempo) numa folha de papel milimetrado.

b) O material deve ser uma substância ou uma mistura? Explique sua resposta.

c) Qual deve ser o estado físico do material após 1 minuto?

6. Consultando a tabela II.1, diga qual deveria ser, na sua opinião, o estado físico da acetona e do benzeno a $56,2^{\circ} \mathrm{C}$ e a $80,1^{\circ} \mathrm{C}$, respectivamente.

\section{VIII - Questões para discussão}

1. Na Terra, uma das temperaturas mais baixas é observada no Pólo Norte (aproximadamente $-100^{\circ} \mathrm{C}$ ). Pensando nisso, você acha que o ponto de ebulição do oxigênio deve ser menor ou maior que $50 \stackrel{\circ}{C}$ ? Explique sua resposta.

2. Que cuidados deveriam ser tomados no acondicionamento e transporte de líquidos de baixo ponto de ebulição?

3. É possível distinguir-se duas misturas de água e glicerina formadas por proporções diferentes destas substâncias? Como? 
4. Existem misturas, chamadas de misturas azeotrópicas, que apresentam um único valor para o ponto de ebulição. Um exemplo é a mistura constituída por $96 \%$ e álcool etílico e $4 \%$ de água. Como você explica este fato?

\section{GUIA EXPERIMENTAL II-2}

PONTO DE FUSÃO

\section{I- Introdução}

Como você viu no experimento anterior, o ponto de ebulição de uma substância é uma constante física, pois apresenta um único valor que depende apenas da substância e não da quantidade da mesma. Assim, o ponto de ebulição pode ser utilizado para identificação de uma substância.

No entanto, existem substâncias que possuem pontos de ebulição muito próximos. Por exemplo, o ponto de ebulição do álcool isopropílico é $82,4^{\circ} \mathrm{C}$ e do álcool tercisobutílico é $82,2^{\circ} \mathrm{C}$ e ambas as substâncias são líquidos incolores à temperatura ambiente. Neste caso, seria extremamente difícil a distinção destas duas substâncias apenas pelos seus pontos de ebulição. É necessário, portanto conhecer outras propriedades características destas substâncias para que se possa identificá-las com maior confiabilidade.

E no caso de ser necessário identificar uma substância sólida? Seria prático determinar seu ponto de ebulição?

Através do gosto é possível distinguir dois sólidos como o sal e o açúcar. Mas, num laboratório, experimentar materiais é uma prática proibida! E como você poderia, por exemplo, saber que uma porção de ácido acetilsalicílico - principal constituinte da aspirina está isenta de outros materiais que até poderiam ser nocivos à saúde? $\mathrm{E}$, ainda, como saber se aquele ácido, preparado à partir de uma reação química, é realmente o ácido acetilsalicílico?

Para responder a esta questão também é necessário conhecer outras propriedades físicas das substâncias. Uma das maneiras seria observar o comportamento destas substâncias sólidas quando submetidas ao aquecimento. 
Geralmente, um sólido, quando aquecido, começa a se transformar em líquido ao alcançar uma determinada temperatura, isto é, começa a fundir: a temperatura na qual ocorre a fusão de um sólido é denominada ponto de fusão. Por outro lado, um líquido ao ser resfriado, transforma-se em sólido, ou seja, solidifica. A temperatura em que ocorre a solidificação de um líquido é denominada ponto de solidificação.

Como estas propriedades físicas podem ser utilizadas para caracterizar uma substância sólida e diferenciá-la de uma mistura?

Para responder a esta questão você deverá realizar o experimento a seguir, onde analisará a variação da temperatura em função do tempo durante o aquecimento e a fusão ou resfriamento e a solidificação, de dois materiais diferentes. Através desta análise você vai ser capaz de:

- redefinir o que é uma substância;

- comparar o ponto de fusão e o ponto de solidificação de uma substância;

- verificar se o ponto de fusão é uma constante física;

- verificar se o ponto de fusão pode ser utilizado para identificar uma substância e distingui-la de uma mistura.

\section{II - Material Necessário}

2 tubos de ensaio

1 termômetro de -10 a $110^{\circ} \mathrm{C}$

1 aro ou tripé

1 mufa

1 bico de Bunsen

1 tenaz

naftalina

água
1 béquer de $250 \mathrm{ml}$

1 suporte universal

1 garra

1 cronômetro ou relógio com marcador de segundos

1 tela de amianto

1 almofariz e pistilo

parafina 


\section{III- Procedimento}

1. Trabalhe com segurança: Cuidado com as queimaduras lembre-se de que o vidro quente tem o mesmo aspecto que o vidro frio. Se a bancada for de azulejo, não coloque materiais quentes diretamente sobre ela; coloque-os sobre uma tela de amianto.

2. Coloque água até aproximadamente $3 / 4$ do volume do béquer.

3. Triture algumas bolinhas de naftalina no almofariz e, a seguir, coloque a quantidade indicada pelo seu professor num dos tubos de ensaio.

4. Monte a aparelhagem conforme mostra a

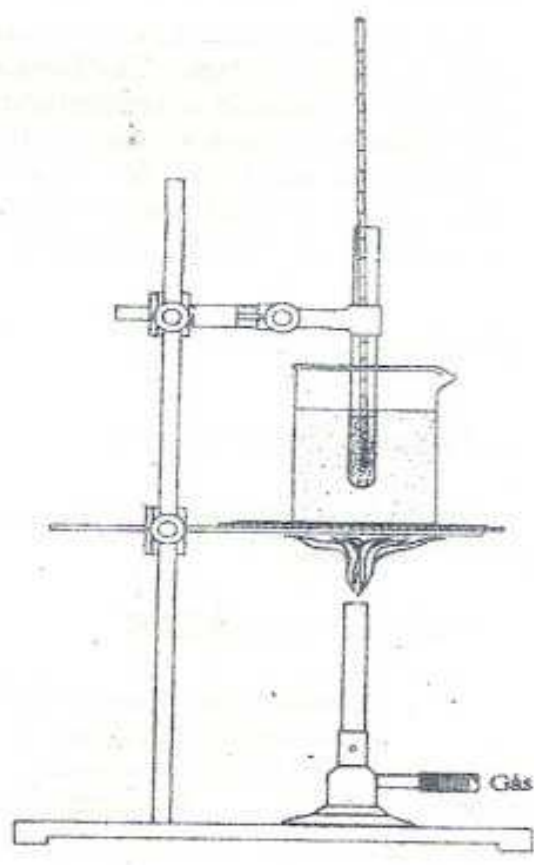

Figura Ii.2 figura II.2.

5. Após mergulhar na água do béquer o tubo de ensaio contendo o sólido e o termômetro, ligue o bico de Bunsen e inicie o aqueciemento. Se a água começar a ferver, desligue o bico de Bunsen.

6. Durante o aquecimento, agite o sólido com o termômetro, CUIDADOSAMENTE.

7. Anote a temperatura do sólido na tabela de dados a cada 15 segundos. Assinale, na tabela, a temperatura na qual se inicia e a temperatura na qual se completa a fusão do sólido.

8. Continue a anotar os dados até que a temperatura do material atinja cerca de $90^{\circ} \mathrm{C}$.

9. Retire, então, o tubo de ensaio da água conforme mostra a figura II.3 e comece imediatamente a anotar a temperatura do material a cada 15 segundos.

10. Durante o resfriamento agite o material com 0 termômetro, CUIDADOSAMENTE. Assinale a temperatura em que se inicia e a temperatura em que se completa a solidificação. Continue a anotar os dados até que a temperatura do material atinja cerca de $50^{\circ} \mathrm{C}$.

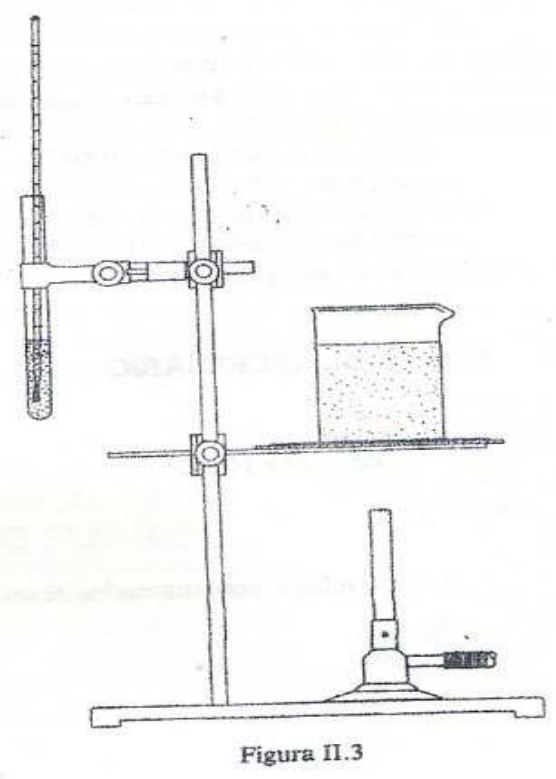

11. Repita todo o procedimento descrito utilizando uma amostra de parafina. 


\section{IV- Tabela de Dados}

Reproduza em seu caderno, as tabelas a seguir com espaço suficiente para a anotação dos dados.

\section{V- Análise dos Dados}

1. Construa num mesmo papel milimetrado, o gráfico que representa o aquecimento da naftalina e o que representa seu resfriamento, colocando a temperatura em ordenadas e o tempo em abscissas. Construa, também, os gráficos que representam o aquecimento e o resfriamento da parafina num outro papel milimetrado.

2. Indique o estado físico do material para cada ponto do gráfico.

3. Qual é a temperatura em que ocorre a solidificação da naftalina? E da parafina? Verifique nos gráficos e compare com os resultados das outras equipes.

\section{Parafina}

\section{Aquecimento}

\begin{tabular}{|l|l|l|}
\hline Tempo & Temperatura & \\
\hline & & \\
& & \\
& & \\
& & \\
& & \\
\end{tabular}


Resfriamento

\begin{tabular}{|l|l|l|}
\hline Tempo & Temperatura & \\
\hline & & \\
& & \\
& & \\
& & \\
& & \\
\end{tabular}

Naftalina

Aquecimento

\begin{tabular}{|l|l|l|}
\hline Tempo & Temperatura & \\
\hline & & \\
& & \\
& & \\
& & \\
& & \\
\end{tabular}


Resfriamento

\begin{tabular}{|l|l|l|}
\hline Tempo & Temperatura & \\
\hline & & \\
& & \\
& & \\
& & \\
& & \\
& & \\
&
\end{tabular}

4. A naftalina apresenta um único valor para o ponto de solidificação? E a parafina? Explique.

5. A temperatura de fusão da naftalina é próxima à sua temperatura de solidificação? Verifique os valores que você obteve. Pode-se admitir que estas temperaturas sejam iguais?

6. Qual é o ponto de fusão da naftalina?

7. A parafina apresenta um único valor para o ponto de fusão? Explique a sua resposta.

\section{VI- Conclusões}

Neste experimento você comparou o comportamento da naftalina e da parafina, dois sólidos igualmente brancos, frente ao aquecimento e ao resfriamento. No entanto, você pode observar que a parafina, que é uma mistura de várias substâncias, apresenta uma faixa de temperatura onde ocorre a fusão e uma faixa de temperatura correspondente à solidificação. Já a naftalina, que é constituída por uma única substância, o naftaleno, apresenta uma única temperatura de fusão e de solidificação. Além disso, ao comparar o 
ponto de fusão que você determinou com os valores obtidos pelos outros colegas para outras amostras de naftalina, você notou que esses valores são muito próximos .

1. Considerando que a quantidade de naftalina variou a cada grupo, você pode dizer que o ponto de fusão depende da quantidade de material?

2. Considerando que cada grupo de alunos utilizou naftalina de diferentes fabricantes, você pode dizer que o ponto de fusão depende da procedência da amostra?

3. Os valores do ponto de fusão e do ponto de solidificação são constantes físicas?

A Tabela II.2 mostra os pontos de fusão e de solidificação de alguma substâncias

TABELA II-2

Pontos de fusão e de solidificação de algumas substâncias à pressão normal

\begin{tabular}{|c|c|c|}
\hline Substância & Ponto de Fusão $\left({ }^{\circ} \mathrm{C}\right)$ & Ponto de solidificação $\left({ }^{\circ} \mathrm{C}\right)$ \\
\hline Uréia & 135 & 135 \\
\hline Ferro & 1535 & 1535 \\
\hline Cloreto de sódio & 801 & 801 \\
\hline Açúcar & 185 & 185 \\
\hline Água & 0 & 0 \\
\hline Alumínio & 660,2 & 660,2 \\
\hline Tolueno & -95 & -95 \\
\hline
\end{tabular}

Analisando suas respostas anteriores e a tabela II.2, responda:

4. Para caracterizar uma substância é necessário determinar tanto o ponto de fusão como o ponto de solidificação? Explique sua resposta.

5. O ponto de fusão é uma propriedade característica de uma substância? Explique sua resposta.

6. Você poderia, através do ponto de fusão, diferenciar várias substâncias da mesma cor?

7. Como se pode distinguir uma substância sólida de uma mistura?

8. Considerando suas conclusões neste experimento e no experimento anterior defina substância.

9. Considerando suas conclusões neste experimento e no experimento anterior defina mistura. 


\section{VII - Exercícios}

1. Se você realizar uma reação química para obter o ácido acetilsalisílico, como pode ter certeza de que se trata dele mesmo? Como você pode saber se está ou não puro?

2. Os gráficos abaixo, construídos na mesma escala, mostram a variação da temperatura com o tempo durante o aquecimento de cinco amostras de sólidos aparentemente idênticos.
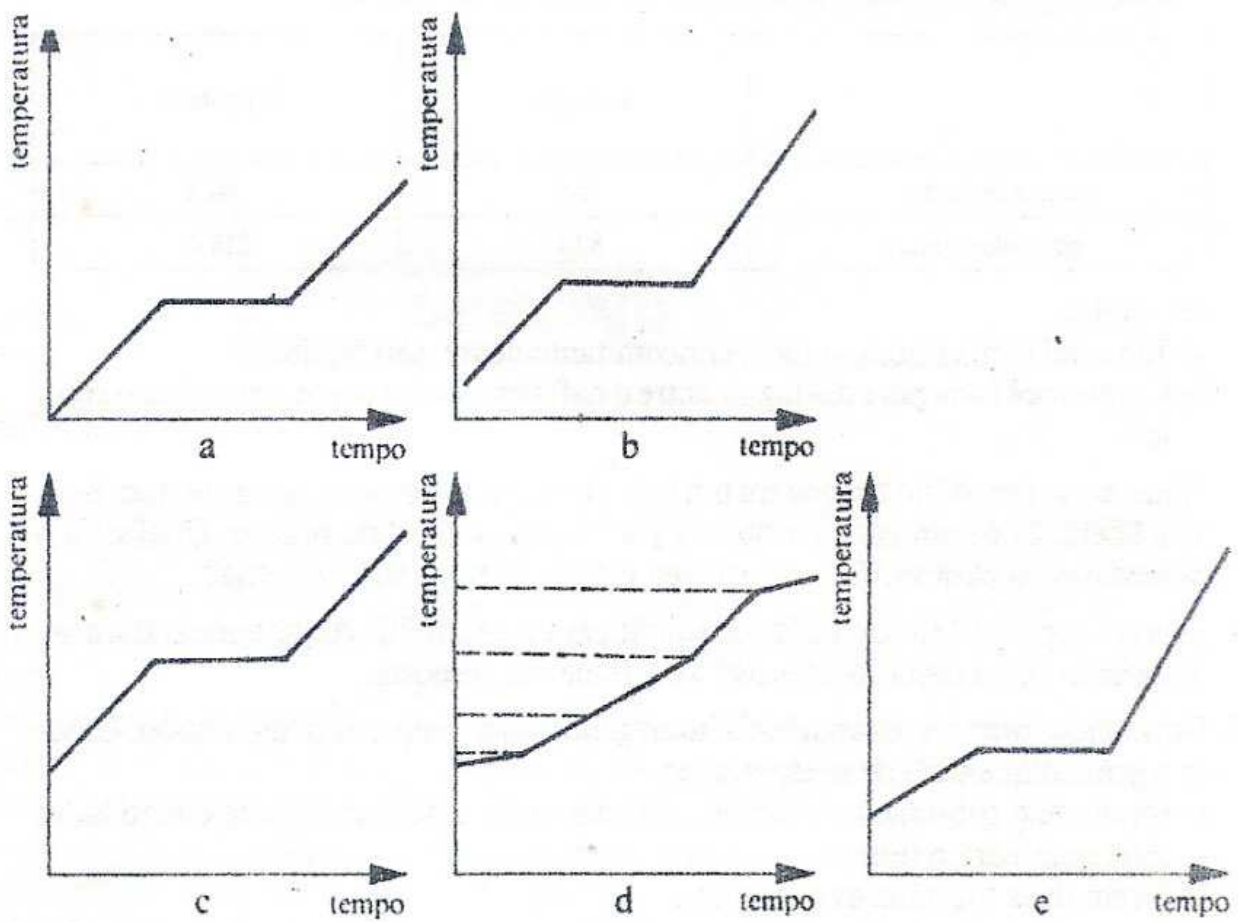

A partir da análise destes gráficos, responda e explique suas respostas:

a) quais das amostras são misturas?

b) Quais das amostras são substâncias?

c) Você pode dizer que há mais de uma amostra da mesma substância?

d) Você pode dizer em qual das amostras há maior quantidade de material?

e) Esboce gráficos que representem o resfriamento das amostras das substâncias. 
3. Proponha um procedimento que possa ser empregado na identificação de um líquido altamente inflamável.

4. Mediu-se o ponto de fusão de dois sólidos brancos e puros. O ponto de fusão encontrado para um deles foi $45^{\circ} \mathrm{C}$ e, para outro, 44,5 C. É possível identificá-los apenas com estes dados?

5. Analise a tabela que se segue e responda à questão.

\begin{tabular}{c|c|c} 
Substância & Ponto de Fusão $\left({ }^{\circ} \mathrm{C}\right)$ & Ponto de Ebulição $\left({ }^{\circ} \mathrm{C}\right)$ \\
\hline Nitrogênio & $-209,86$ & $-195,8$ \\
\hline Bromo & $-7,2$ & 58,78 \\
\hline Metano & $-182,48$ & -164 \\
\hline Difenilcarbinol & 69 & 298
\end{tabular}

A representação $298^{748}$ para o ponto de ebulição do difenilcarbinol significa que este ponto de ebulição (298) foi medido a uma pressão de $748 \mathrm{mmHg}$.

A temperatura ambiente (25ำ C) quais destas substâncias são gases? Quais são líquidos? Quais são sólidos?

6. Dados os pontos de fusão e os pontos de ebulição de naftaleno e benzeno, responda:

\begin{tabular}{lll} 
& Benzeno & Naftaleno \\
\hline Ponto de fusão & 5,5 & 80,2 \\
\hline Ponto de ebulição & 80,1 & 218,0
\end{tabular}

a) Em qual temperatura ambos, concomitantemente são líquidos?

b) Como você faria para distinguir entre o naftaleno e o benzeno, sem olhar 0 rótulo?

7. Aqueceu-se um sólido branco em um tubo de ensaio. Depois de algum tempo, houve a liberação de um gás e notou-se a presença de um sólido branco. Qual seria o procedimento para verificar se ocorreu reação química neste sistema?

8. Sabe-se que $5 \mathrm{ml}$ de ácido sulfúrico solidificaram a $10^{\circ} \mathrm{C}$. A que temperatura solidificará $10 \mathrm{ml}$ desta substância? Justifique sua resposta.

9. Dois sólidos brancos, de aparência homogênea, foram aquecidos até a fusão. Esboce o gráfico que seria de se esperar se: 
a) forem duas substâncias idênticas, mas das quais se tenha utilizado quantidades diferentes para o teste.

b) forem duas substâncias diferentes.

c) forem misturas.

10. Provocou-se o aquecimento de um sólido desconhecido, medindo-se a temperatura do material em intervalos de tempo de 30 segundos, até que todo o material estivesse fundido. Os resultados obtidos estão organizados na tabela seguinte:

\begin{tabular}{|l|l|l|l|l|l|l|l|l|l|l|}
\hline Tempo(s) & 0 & 30 & 60 & 90 & 120 & 150 & 180 & 210 & 240 & 270 \\
\hline Temperatura ${ }^{\circ} \mathrm{C}$ & 25 & 34 & 43 & 51 & 59 & 65 & 68 & 69 & 73 & 80 \\
\hline
\end{tabular}

a) A partir destes dados, construa o gráfico (temperatura $X$ tempo) numa folha de papel milimetrado.

b) O material deve ser uma mistura ou uma substância? Explique.

c) Qual é o estado físico do material após 4, 5 minutos de aquecimento?

\section{VIII - Questões para discussão}

1. O ponto de fusão da glicerina é $17^{\circ} \mathrm{C}$. Qual é o estado físico desta substância no dia de hoje?

2. O ponto de fusão da amônia é $-77,7^{\circ} \mathrm{C}$. Num determinado ponto do Pólo Norte, onde a temperatura fosse $-80^{\circ} \mathrm{C}$, em que estado físico você encontraria esta substância?

3. Um estudante misturou dois sólidos num laboratório e notou uma mudança de cor. Como ele pode ter certeza de que tenha ocorrido uma reação química?

4. Por que Vodka não solidifica, mesmo na Sibéria?

5. Existem algumas misturas chamadas misturas eutéticas que apresentam temperatura constante durante a fusão, por exemplo, a liga metálica formada pela mistura de chumbo e arsênio. Como você explica este fato? 
GUIA EXPERIMENTAL II -3

\section{DENSIDADE}

\section{I- Introdução}

O álcool anidro e o álcool hidratado são líquidos de mesmo aspecto e de mesmo odor. Uma propriedade utilizada para distinguir esses dois líquidos é a densidade. Além disso, conhecendo-se a densidade de uma amostra de álcool hidratado pode-se determinar a composição da amostra, ou seja, a quantidade de álcool e de água que constituem a mistura.

Mas de que modo a determinação da densidade possibilita a caracterização de uma substância? E de que maneira o conhecimento desta propriedade permite distinguir uma substância de uma mistura?

Através deste experimento você vai encontrar respostas para estas questões pois, ao final da atividade, você deverá ser capaz de :

- definir densidade;

- julgar se a densidade permite diferenciar uma substância de uma outra mistura.

\section{II- Material Necessário}

3 frascos pequenos e iguais

água

ácido sulfúrico

alumínio

1ovo

III - Procedimento, Analise de dados e Conclusões

Parte A
1 béquer de $400 \mathrm{ml}$

mercúrio

sal

ferro 
1. Seu professor vai the indicar três frascos contendo volumes iguais de três substâncias líquidas: água, ácido sulfúrico e mercúrio. Segure cada um dos frascos com cuidado. O que você nota?

2. As massas contidas em volumes iguais destas substâncias são iguais? Justifique sua resposta.

3. Agora compare a massa de uma amostra de ferro e de uma amostra de alumínio aproximadamente de mesmo volume. Para isso segure cada uma delas numa mão. $O$ que você nota?

4. As massas contidas em volumes iguais dessas substâncias são iguais? Justifique sua resposta.

Nesta atividade você comparou as massas de volume iguais de algumas substâncias. Assim, você pôde perceber que as massas de cada uma das substâncias que ocupam um mesmo volume são diferentes. A relação entre a massa $(m)$ e o volume (V) de uma determinada substância é expressa matematicamente pela razão $\mathrm{m} / \mathrm{V}$. Esta razão é a densidade da substância. Em geral, a densidade é expressa em $\mathrm{g} / \mathrm{cm}^{3}$. Assim a densidade indica a massa (em gramas) que ocupa um volume de $1 \mathrm{~cm}^{3}$

A tabela II. 3 mostra a densidade de algumas substâncias.

Tabela II-3

DENSIDADE DE ALGUMAS SUBSTÂNCIAS À TEMPERATURA AMBIENTE

\begin{tabular}{ll} 
Substância & Densidade \\
\hline Mercúrio & 13,546 \\
\hline Ácido sulfúrico & 1,841 \\
\hline Água & 1,00 \\
\hline Ferro & 7,86 \\
\hline Alumínio & 2,702 \\
\hline Chumbo & 11,3 \\
\hline Cobre & 8,9 \\
\hline Ouro & 19,3 \\
\hline Álcool metílico & 0,79
\end{tabular}

5. Qual das substâncias acima apresenta maior densidade?

6. Se tivéssemos volumes iguais de ouro, cobre e chumbo qual apresentaria menor massa? Explique sua resposta.

7. Se tivéssemos massas iguais de ácido sulfúrico, mercúrio e água os volumes seriam iguais? Explique sua resposta. 
8. A densidade de uma amostra de $10 \mathrm{~cm}^{3}$ de ferro é diferente da densidade de uma amostra de $5 \mathrm{~cm}^{3}$ de ferro? Explique sua resposta.

9. A densidade de uma amostra de $27 \mathrm{~g}$ de alumínio é diferente da densidade de uma amostra de $270 \mathrm{~g}$ de alumínio?Explique sua resposta.

10. A densidade de uma substância é uma constante física?

11. A densidade pode ser utilizada para caracterizar uma substância ? Explique sua resposta.

Como seria possivel determinar experimentalmente a densidade de uma substância?

Como a densidade é a razåo entre a massa e ovolume, pode-se determinar a densidade medindo-se a massa numa balança e 0 volume numa proveta, no caso de líqüidos. No caso de alguns sólidos, pode-se medir o volume imergindo o sólido num liqutido contido numa proveta e observando o volume de lig̨idido deslocado conforme indica a figura il.4.

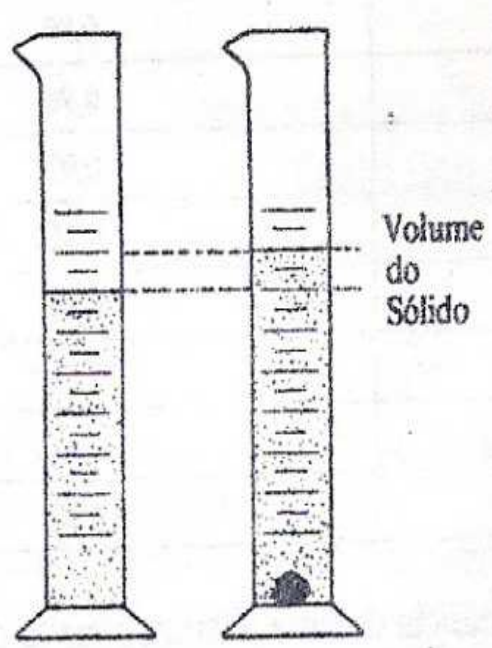

Figura II.4

Medida do volume de um sólido através do volume de liqüiido deslocado.
Alem disso existem aparelhos que medem diretamente a densidade como os densimetros, utilizados para liquidos (figura 11.5).

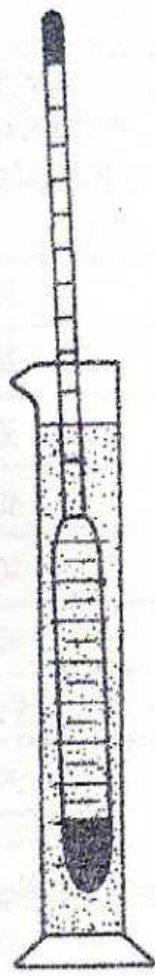

Figura II.5

O densimetro mede diretamente a densidade dos liquaidos. 


\section{Parte B}

Neste experimento utilizaremos um ovo para comparar densidades de líquidos.

1. Coloque um ovo num béquer com água e observe.

2. Adicione 2 colheres de sal à água contida no béquer e agite. O que você nota?

3. Vá adicionando mais sal aos poucos. O que acontece com o ovo?

4. Você pode dizer que a densidade do líquido permanece a mesma com a adição do sal?

5. Diferentes misturas de água e sal apresentam a mesma densidade? Explique sua resposta.

Assim, como no caso da mistura água e sal , a mistura água e álcool (álcool hidratado) também não apresenta uma densidade característica. A densidade da mistura varia com a composição, isto é, com as quantidades de álcool e água presentes na amostra. No entanto, para uma determinada composição fixa têm-se uma densidade determinada. Conhecendose a densidade de uma mistura é possível saber a sua composição?

Também outras misturas como as ligas metálicas, que são mistura de metais, apresentam densidades diferentes dependendo da composição.

A Tabela II. 4 mostra a densidade de misturas de álcool etílico (etanol) e água, de diversas composições.

$$
\text { Tabela II }-4
$$

Relação entre a composição e a densidade da mistura de água e etanol

\section{Composição (volume de etanol em $100 \mathrm{~cm}^{3}$} de mistura)

\begin{tabular}{cc}
\hline 10,0 & 0,99 \\
\hline 20,0 & 0,98 \\
\hline 30,0 & 0,97 \\
\hline 40,0 & 0,95 \\
\hline 50,0 & 0,93 \\
\hline 92,0 & 0,83 \\
\hline 96,0 & 0,81 \\
\hline 99,0 & 0,80
\end{tabular}

\section{Densidade $\left(\mathbf{g} / \mathrm{cm}^{3}\right)$}


6- Como é possível distinguir uma substância de uma mistura através da densidade?

\section{EXERCÍCIOS}

1. Considerando a tabela:

\begin{tabular}{llll} 
Substância & Ponto de Fusão & Ponto de Ebulição & Densidade \\
\hline Álcool etílico & 117,3 & 78,5 & 0,7893 \\
\hline Acetona & 95,35 & 56,2 & 0,7899 \\
\hline Ácido sulfúrico & 10 & 340 & 1,834 \\
\hline Benzeno & 5,5 & 80,1 & 0,87865 \\
\hline Tolueno & -95 & 110,6 & 0,8669 \\
\hline $\begin{array}{l}\text { Trinitrotolueno } \\
\text { (TNT) }\end{array}$ & 82 & Explode a 240 & 1,654 \\
\hline Sulfato de cobre II & 110 & 150 & 2,284 \\
\hline Ferro & 1535 & 3000 & 7,86 \\
\hline Alumínio & 660,2 & 2467 & 2,702 \\
\hline Naftaleno & 80,55 & 218 & 1,0253
\end{tabular}

a) Quais substâncias podem ser encontradas no estado sólido na temperatura de $80^{\circ} \mathrm{C}$ ?

b) Quais substâncias certamente são encontradas no estado líquido na temperatura de $110^{\circ} \mathrm{C}$ ?

c) Como você faria, estando no laboratório, para distinguir entre dois frascos sem rótulos, sabendo que em um deles há naftaleno e, em outro, há benzeno?

d) Onde há maior massa, em um litro de ácido sulfúrico ou e dois litros de tolueno? Explique sua resposta.

e) Como você faria, estando no laboratório, para distinguir entre dois frascos sem rótulos, sabendo que em um deles há benzeno e, no outro, há tolueno e sabendo também, que ambas substâncias são inflamáveis em temperaturas elevadas?

\section{V- Questões para Discussão}

1. Como você explicaria o funcionamento dos aparelhos de controle de qualidade do álcool hidratado existentes nos postos de distribuição de combustíveis?

2. A densidade do ferro é muito maior do que a da água. Por que um navio de ferro não afunda? 
ANEXO C - Tabelas construídas individualmente pelos alunos participantes da pesquisa, enfocando o caráter macroscópico da transformação de sistemas, com o objetivo de se observar as concepções prévias dos educandos a respeito do conceito de transformação dos materiais.

ANEXO C1 - Tabela individual de evocações de transformações do ano de 2006

\begin{tabular}{|c|c|c|c|c|}
\hline \multicolumn{5}{|c|}{ Turmas ( $n^{o}$ de alunos): evocações em \% } \\
\hline$N^{o}$ & Evocações & $A(17)$ & $B(18)$ & $\begin{array}{llll}\text { Justificativa } & \text { de } & \text { reconhecimento } & d a \\
\text { transformação } & & & \\
\end{array}$ \\
\hline 1 & $\begin{array}{l}\text { Queima do papel e } \\
\text { pneu }\end{array}$ & 94 & -- & $\begin{array}{l}\text { Colocar fogo e começar o aparecimento de cinzas, } \\
\text { mudança de cor, combustão, fumaça, cheiro, cor, } \\
\text { consistência, derrete }\end{array}$ \\
\hline 2 & $\begin{array}{l}\text { Refrigerante e } \\
\text { cerveja }\end{array}$ & 48 & -- & $\begin{array}{l}\text { Cor, sabor, gases, fermentação, mistura de gás com } \\
\text { líquido, presença de álcool }\end{array}$ \\
\hline 3 & $\begin{array}{l}\text { Crescimento de } \\
\text { pessoas }\end{array}$ & 24 & -- & Com o passar do tempo \\
\hline 4 & Cozinhar ovos & 35 & -- & $\begin{array}{l}\text { Ao ferver a água, ao colocar na água quente começa o } \\
\text { cozimento }\end{array}$ \\
\hline 5 & $\begin{array}{l}\text { Lata enferrujando/ } \\
\text { enferrujada }\end{array}$ & 76 & -- & $\begin{array}{l}\text { Com o aparecimento de pequenas ferrugens, presença } \\
\text { de oxigênio, oxidação, presença de umidade, cor, } \\
\text { textura }\end{array}$ \\
\hline 6 & Motor ligado & 88 & -- & $\begin{array}{l}\text { Combustão, presença de oxigênio misturado com o } \\
\text { combustível }\end{array}$ \\
\hline 7 & Apontar lápis & 47 & -- & De acordo como você vai apontando ele fica menor \\
\hline 8 & $\begin{array}{l}\text { Derreter/ } \\
\text { derretimento do } \\
\text { chumbo }\end{array}$ & 41 & -- & $\begin{array}{l}\text { Pela alta temperatura, presença de fogo, de calor, } \\
\text { mudança de estado físico }\end{array}$ \\
\hline 9 & Digestão & 59 & -- & $\begin{array}{l}\text { Quebra de moléculas, transformar bolo alimentar em } \\
\text { nutrientes/ comer comida/diluição dos alimentos }\end{array}$ \\
\hline 10 & $\begin{array}{l}\text { Cicatrização/ } \\
\text { cicatrizar ferida }\end{array}$ & 47 & -- & $\begin{array}{l}\text { Presença de sangue, glóbulos brancos, formação de } \\
\text { casca, cor, cheiro, formação de pus, corte na pele }\end{array}$ \\
\hline 11 & Decomposição & 29 & -- & $\begin{array}{l}\text { Presença de insetos e animais, odor, mudança de } \\
\text { casca/ organismos mortos/ desmancha, cheiro, } \\
\text { pedaços, animais em volta }\end{array}$ \\
\hline 12 & $\begin{array}{l}\text { Pintar cabelo/ tinta } \\
\text { de cabelo }\end{array}$ & 53 & -- & Cor, cheiro, enfraquecimento dos fios \\
\hline 13 & Fazer café & 12 & -- & Ferver água \\
\hline 14 & $\begin{array}{l}\text { Vaporização, } \\
\text { fusão, } \\
\text { condensação, } \\
\text { solidificação }\end{array}$ & 36 & -- & $\begin{array}{l}\text { Água fervendo, gelo derretendo, chuva, água no } \\
\text { congelador }\end{array}$ \\
\hline 15 & $\begin{array}{l}\text { Fruta crescendo na } \\
\text { árvore }\end{array}$ & 6 & -- & Tamanho, cor, gosto \\
\hline 16 & $\begin{array}{l}\text { Apodrecimento de } \\
\text { uma fruta }\end{array}$ & 6 & -- & A fruta fica podre, muda a cor, o cheiro e o gosto \\
\hline 17 & Fazer papel & -- & 78 & $\begin{array}{l}\text { Transformação da madeira em celulose, tira a celulose } \\
\text { da madeira para fazer papel, muda o formato }\end{array}$ \\
\hline 18 & $\begin{array}{l}\text { Comprimido } \\
\text { efervescente }\end{array}$ & -- & 78 & $\begin{array}{l}\text { Quando coloca na água ele dissolve, quando amassa } \\
\text { vira pó, faz borbulhar }\end{array}$ \\
\hline
\end{tabular}




\begin{tabular}{|c|c|c|c|c|}
\hline \multicolumn{5}{|c|}{ Turmas ( $n^{o}$ de alunos): evocações em \% } \\
\hline$N^{o}$ & Evocações & $A(17)$ & $B(18)$ & $\begin{array}{l}\text { Justificativa de reconhecimento da } \\
\text { transformação }\end{array}$ \\
\hline 19 & $\begin{array}{l}\text { Cozinhar carne e } \\
\text { arroz }\end{array}$ & -- & 83 & $\begin{array}{l}\text { Deixa de ser dura, fica cozida e com sabor, muda a } \\
\text { cor (tempero), o gosto e a consistência }\end{array}$ \\
\hline 20 & Unhas & -- & 6 & Crescimento \\
\hline 21 & Fazer vidro & -- & 11 & Mudança de textura, de cor e fica transparente \\
\hline 22 & $\begin{array}{l}\text { Transformar } \\
\text { petróleo em } \\
\text { combustível }\end{array}$ & -- & 11 & $\begin{array}{l}\text { Processo que pega o petróleo e passa a ficar } \\
\text { combustível }\end{array}$ \\
\hline 23 & Reciclagem & -- & 6 & $\begin{array}{l}\text { Do papel, vidro, plástico e metais para fazer novos } \\
\text { objetos }\end{array}$ \\
\hline 24 & $\begin{array}{l}\text { Transformar/ fazer/ } \\
\text { fermentação de pães } \\
\text { e bolos }\end{array}$ & 59 & 100 & $\begin{array}{l}\text { No forno ele cresce, muda a consistência, cor, o } \\
\text { fermento faz crescer, o forno faz crescer, fica duro }\end{array}$ \\
\hline 25 & Cozinhar feijão & 6 & 22 & Quando cru era duro, quando cozinha fica mole \\
\hline 26 & $\begin{array}{l}\text { Funcionamento de } \\
\text { um automóvel/ } \\
\text { ônibus/ moto }\end{array}$ & 6 & 89 & $\begin{array}{l}\text { Fumaça do escapamento, queimação do } \\
\text { combustível, liberação de gás, cheiro, cor }\end{array}$ \\
\hline 27 & Milho de pipoca & 6 & 83 & Estoura, muda de cor, macio, crocante \\
\hline 28 & Respiração & 12 & 83 & $\begin{array}{l}\text { Inspira oxigênio e expira gás carbônico, respira } \\
\text { poluição, mudança de oxigênio para gás carbônico }\end{array}$ \\
\hline 29 & $\begin{array}{l}\text { Fazer escova no } \\
\text { cabelo/fazer } \\
\text { relaxamento no } \\
\text { cabelo }\end{array}$ & 18 & 72 & $\begin{array}{l}\text { Alisa o cabelo, agride os fios, a queratina e a } \\
\text { ceramida restauram os fios }\end{array}$ \\
\hline 30 & $\begin{array}{l}\text { Transformar } \\
\text { água/água fervendo }\end{array}$ & 18 & 11 & $\begin{array}{l}\text { Sólido, líquido e gasoso, evaporação, em ambiente } \\
\text { muito frio ela congela, o gelo em ambiente quente } \\
\text { derrete }\end{array}$ \\
\hline 31 & Madeiras/queima & 6 & 17 & $\begin{array}{l}\text { Transformação de mesas, cadeiras, camas, palitos, } \\
\text { poluição, fumaça }\end{array}$ \\
\hline 32 & $\begin{array}{l}\text { Desenvolvimento de } \\
\text { plantas e sementes }\end{array}$ & 76 & 78 & $\begin{array}{l}\text { Cor, estrutura, de uma semente colocada na terra } \\
\text { vira árvore, fotossíntese, germinação, algumas } \\
\text { ficam com cheiro, decomposições, } \\
\text { desenvolvimento, respiração }\end{array}$ \\
\hline 33 & Gelatina & 53 & 6 & $\begin{array}{l}\text { Endurecimento, foi do líquido para o sólido e muda } \\
\text { a forma, cor, gosto e consistência }\end{array}$ \\
\hline 34 & $\begin{array}{l}\text { Pão amanhecido/ } \\
\text { pão embolorando }\end{array}$ & 18 & 6 & Fica murcho/ fica duro, cor, cheiro \\
\hline
\end{tabular}




\begin{tabular}{|c|c|c|c|c|c|}
\hline \multicolumn{6}{|c|}{ Turmas ( $n^{o}$ de alunos): evocações em \% } \\
\hline$N^{o}$ & Evocações & $1 A(24)$ & $1 B(32)$ & $1 C(27)$ & $\begin{array}{l}\text { Justificativa de reconhecimento da } \\
\text { transformação }\end{array}$ \\
\hline 1 & $\begin{array}{l}\text { Chapinha } \\
\text { cabelo/ Tintura de } \\
\text { cabelo/ tingir o } \\
\text { cabelo/ pintar o } \\
\text { cabelo/ tingimento } \\
\text { do cabelo/ ir ao } \\
\text { cabeleireiro }\end{array}$ & 4 & 27 & 13 & $\begin{array}{l}\text { Quando passa no cabelo alisa/ Cor diferente, } \\
\text { novo visual/ após a tintura seu cabelo sofre } \\
\text { uma química e muda de cor/ de cabelo } \\
\text { colorido para cabelo preto/ muda o pigmento } \\
\text { do cabelo }\end{array}$ \\
\hline 2 & 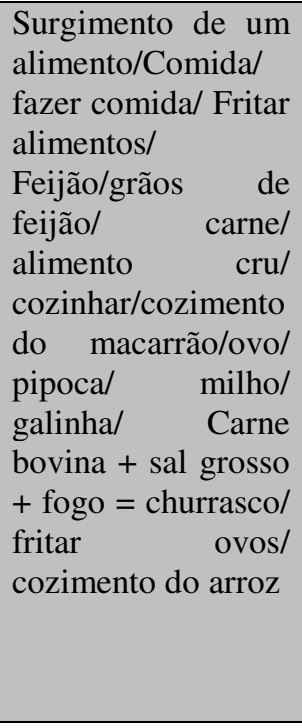 & 12 & 12 & 25 & $\begin{array}{l}\text { A mistura de ingredientes químicos/ Aqueça a } \\
\text { comida/ com os temperos e o fogo fazemos } \\
\text { uma deliciosa comida/ após comermos } \\
\text { acontece a digestão/ O alimento estava cru, } \\
\text { mas após fritá-lo ele fica mais saboroso e } \\
\text { dura mais/ Coloca para cozinhar duro e sai } \\
\text { mole/ quando cozido ele se torna comestível/ } \\
\text { Põe no fogo cru e sai cozida/ quando cozinha } \\
\text { ele fica mole/ antes de cozinhá-lo ele está cru/ } \\
\text { Amolece na água quente/ Depois que põe o } \\
\text { óleo ele frita/ formação de vários outros } \\
\text { elementos/ Antes era milho, coloca óleo e se } \\
\text { transforma em pipoca/ depois de frito vira } \\
\text { pipoca/ quando está cozinhando/ Muda de } \\
\text { cheiro, cor e sabor/ o ovo estava líquido, } \\
\text { adquiriu consistência, sabor, cor, cheiro/ } \\
\text { muda a textura/ quando o milho se abre e vira } \\
\text { pipoca }\end{array}$ \\
\hline 3 & $\begin{array}{l}\text { Gelatina/ formação; } \\
\text { preparo da gelatina }\end{array}$ & 2 & & 4 & $\begin{array}{l}\text { Quando põe na geladeira endurece/ o pó, a } \\
\text { água quente e fria/ antes era um pó que se } \\
\text { dissolveu na água quente e foi refrigerado, } \\
\text { ficando com uma consistência gelatinosa }\end{array}$ \\
\hline 4 & $\begin{array}{l}\text { Azul }+ \text { amarelo/ } \\
\text { Vermelho }+ \text { azul/ } \\
\text { Tinta vermelha } \\
\text { com } \quad \text { preta/ } \\
\text { mudança de cor }\end{array}$ & 4 & & & $\begin{array}{l}\text { Misturando vira verde/ Misturando vira roxo/ } \\
\text { Se juntá-las se transforma em marrom/ Vendo } \\
\text { a mudança de mistura das cores }\end{array}$ \\
\hline 5 & $\begin{array}{l}\text { Máquina de lavar } \\
\text { roupa/ lavar roupa }\end{array}$ & 2 & & 1 & $\begin{array}{l}\text { Coloca a roupa suja e sai limpa/ coloca a } \\
\text { roupa suja na máquina e sai limpa }\end{array}$ \\
\hline 6 & $\begin{array}{l}\text { Cafél pó de cafél } \\
\text { Esquentar água } \\
\text { para fazer o café }\end{array}$ & 8 & & 1 & $\begin{array}{l}\text { Com o pó mais água quente/ fervente vira } \\
\text { café/ com a água quente se transforma/ } \\
\text { Presença de vapor; fervendo antes a água } \\
\text { estava numa temperatura ambiente e logo } \\
\text { após ficou quente/ temperatura efervescente/ } \\
\text { que o gás do fogão reage com o oxigênio do } \\
\text { ar para produzir o calor que utilizamos para } \\
\text { cozinhar }\end{array}$ \\
\hline
\end{tabular}




\section{Turmas ( $n^{o}$ de alunos): evocações em \%}

\begin{tabular}{|c|c|}
\hline$N^{o}$ & Evocações \\
\hline 7 & $\begin{array}{l}\text { Árvore/ plantar } \\
\text { semente/ botão/ } \\
\text { botão de rosa/ } \\
\text { Crescimento de } \\
\text { uma planta, flor/ } \\
\text { planta/ uma flor } \\
\text { aberta/ } \\
\text { Crescimento de um } \\
\text { broto de feijão/ Um } \\
\text { grão de feijão vira } \\
\text { um pé de feijão/ } \\
\text { plantação/ molhar } \\
\text { as plantas }\end{array}$ \\
\hline
\end{tabular}

8 Bolo/ fermento no
bolo/ fazendo bolo/
bater um bolo/ Pão/
fazendo pão/
Fermento no pão/
fermentação/ massa

\section{Justificativa de reconhecimento da transformação}

Quando plantada era semente, depois vira uma árvore grande/ a semente é um frutinho, ao ser colocada na terra ela brota e vira uma flor, árvore, etc./ em determinado momento ele vira flor/ depois vira uma rosa/ ela cresce se reproduz e morre/ Ao ela se abrir, se desenvolver, crescer, reproduzir/ após um tempo a flor se transforma em fruto/ nasce, cresce e morre/ antes era um botão, ao agora não é mais/ era semente e depois de um tempo ela se tornou uma planta, árvore/ Aumentou de tamanho, a cor ficou mais forte/ Se você jogar alguns grãos de feijão na terra vão nascer muitos feijões/ depois de podar/ se a pessoa colocar a planta no sol ela morre e se colocar água ela sobrevive/ germinação/ elas crescem

Coloca no forno pequeno e sai grande/ quando põe no forno cresce e fica sólido/ misturando os ingredientes, usando fermento, o bolo cresce conforme ele assa/ Virou uma massa, o fungo o fez crescer/ leite com farinha e fermento/ misturando ovos, farinha, açúcar, sal, fermento e leite, levar ao forno para aquecer para o fermento agir e assar o pão/ Quando põe no forno cresce/ uma série de processos/fermento faz o pão crescer/ Foi preparada, assada e houve a transformação

Quando está fervendo evapora/ depois de ser congelada ela vira gelo/ A água era líquida e ficou sólida/ vira água quando sai da geladeira, era sólido e ficou líquido/ era uma água e após tal temperatura virou gelo/ derrete/ o gelo é feito da água, ao ficar duro ele se torna sólido, quando derrete volta a ser líquido/ quando não está em vapor é apenas água/ Presença de vapor; fervendo antes a água estava numa temperatura ambiente e após ficou quente

\begin{tabular}{llllll}
\hline 10 & $\begin{array}{l}\text { Café e leite/ água e } \\
\text { suco em pó/ } \\
\text { experimento } \\
\text { químico/ barro + }\end{array}$ & 3 & 1 & 4 & $\begin{array}{l}\text { Com a mistura ele fica cinza/ quando } \\
\text { misturados a água se transforma em suco/ } \\
\text { mistura de coisas/ lama/ de líquido ou pó, } \\
\text { passa a ser espuma, com a junção de água }\end{array}$ \\
$\begin{array}{l}\text { água/ detergente ou } \\
\text { sabão em pó }\end{array}$ & & & $\begin{array}{l}\text { Ao ingerir alimento o que não serve sai/Bebemos } \\
\text { líquido e o que não serve sai pela urina }\end{array}$
\end{tabular}

Suor/ transpiração/
$\begin{aligned} & \text { Esforço físico } \\ & \text { calor do sol = suor }\end{aligned}$




\section{Turmas ( $n^{o}$ de alunos): evocações em \%}

\begin{tabular}{|c|c|c|c|c|c|}
\hline$N^{o}$ & Evocações & $1 A(24)$ & $1 B(32)$ & $1 C(27)$ & $\begin{array}{l}\text { Justificativa de reconhecimento da } \\
\text { transformação }\end{array}$ \\
\hline 13 & Chulé & 1 & & & $\begin{array}{l}\text { Após muito tempo prendendo a } \\
\text { "respiração" do pé sai cheiro }\end{array}$ \\
\hline 14 & $\begin{array}{l}\text { Luz solar em energia } \\
\text { solar }\end{array}$ & & & 1 & $\begin{array}{l}\text { A luz do sol é transformada em energia, } \\
\text { por exemplo, a luz do sol passa por um tipo } \\
\text { de material, similar ao vidro, podendo } \\
\text { então aquecer a água, um cômodo, etc. }\end{array}$ \\
\hline 15 & $\begin{array}{l}\text { Má digestão/ ao } \\
\text { ingerir um alimento e } \\
\text { não cair bem e } \\
\text { vomitá-lo/ Azia/ } \\
\text { vômito/ pêssego + } \\
\text { queijo }\end{array}$ & 5 & & & $\begin{array}{l}\text { Alimentação inadequada/ a rejeição do } \\
\text { estômago/ quando um alimento não cai } \\
\text { bem/ Por comer algo gorduroso e pesado/ } \\
\text { Embrulhamento no estômago ou dor de } \\
\text { barriga }\end{array}$ \\
\hline 16 & $\begin{array}{l}\text { Remédio } \\
\text { (comprimido)/ tomar } \\
\text { remédio/ } \\
\text { medicamentos/ } \\
\text { Estomazil }\end{array}$ & 6 & 4 & & $\begin{array}{l}\text { Dissolvem-se no organismo/ quando } \\
\text { tomamos o remédio nossos organismos } \\
\text { sofrem uma reação e quando não é } \\
\text { rejeitado melhoramos/ Sintetiza novas } \\
\text { moléculas, que curam doenças e fortalece a } \\
\text { saúde humana/ a pessoa está doente, toma o } \\
\text { remédio e fica boa/ Quando põe na água se } \\
\text { dissolve }\end{array}$ \\
\hline 17 & Leite/ queijo & 1 & & 4 & $\begin{array}{l}\text { Se deixar no copo muito tempo vira queijo/ } \\
\text { você faz a transformação de leite em } \\
\text { queijo, do líquido para o sólido/ leite fora } \\
\text { da geladeira azeda e coalha }\end{array}$ \\
\hline 18 & $\begin{array}{l}\text { Blusa colorida/ } \\
\text { tingimento de uma } \\
\text { roupa/ um tecido sujo } \\
\text { e passar água } \\
\text { sanitária }\end{array}$ & 1 & & 3 & $\begin{array}{l}\text { Quando põe na cândida muda de cor/ se } \\
\text { você pegar uma roupa branca e colocá-la } \\
\text { em uma tinta preta, você vai ver que vai } \\
\text { ocorrer uma coloração que vai mudar o } \\
\text { pigmento da roupa/ de uma mancha difícil } \\
\text { de ser tirada e o líquido tirou }\end{array}$ \\
\hline 19 & $\begin{array}{l}\text { Ovo > galinha; o ovo } \\
\text { se transforma em } \\
\text { galinha/ o ovo }\end{array}$ & 6 & 3 & & $\begin{array}{l}\text { Quando o ovo quebra nasce uma galinha/ o } \\
\text { ovo foi chocado por outra galinha e com o } \\
\text { calor, se quebrou e deu origem a outra } \\
\text { galinha/ ou comida para nós ou } \\
\text { pintinho/primeiro ele é um ovo comum, } \\
\text { depois se transforma em pintinho }\end{array}$ \\
\hline 20 & $\begin{array}{l}\text { Madeira > papel/ } \\
\text { árvore/ madeira/ } \\
\text { Papel/ queima do } \\
\text { papel/ queimar papel/ } \\
\text { carvão (queimar) / } \\
\text { queimar madeira }\end{array}$ & 9 & 10 & 10 & $\begin{array}{l}\text { Através de uma técnica e uns tratamentos } \\
\text { específicos fazem o papel/ a árvore tem } \\
\text { várias utilidades com ela fazemos o papel, } \\
\text { fogo, lápis/ a madeira ao ser extraída das } \\
\text { árvores, sofrem uma reação química, assim } \\
\text { tornando-a esculturas/ ao ser queimada } \\
\text { sofre uma transformação/ Quando queima } \\
\text { vira pó/ o papel passou de papel para } \\
\text { cinzas, mudou de cor, diminuiu o peso e } \\
\text { mudou a matéria/ o papel era branco; } \\
\text { estava inteiro e depois virou cinzas/ } \\
\text { Quando queimado vira cinzas/ coloca fogo } \\
\text { em madeira sólida e se transforma em pó/ } \\
\text { desmatar, derrubar, extrair a celulose da } \\
\text { madeira e levar para a fábrica para produzir } \\
\text { papel/ de uma árvore para uma porta. }\end{array}$ \\
\hline
\end{tabular}




\section{Turmas ( $n^{\circ}$ de alunos): evocações em \%}

\begin{tabular}{|c|c|c|c|c|c|}
\hline$N^{o}$ & Evocaç̃̃es & $1 A(24)$ & $1 B(32)$ & $1 C(27)$ & $\begin{array}{l}\text { Justificativa de reconhecimento da } \\
\text { transformação }\end{array}$ \\
\hline 21 & $\begin{array}{l}\text { Espermatozóide }+ \\
\text { óvulo = criança/ } \\
\text { espermatozóide/ } \\
\text { nascendo o bebê/ } \\
\text { Espermatozóide }+ \\
\text { óvulo = zigoto/ } \\
\text { gravidez/ fecundação } \\
\text { do óvulo/ mulher } \\
\text { grávida }\end{array}$ & 5 & 1 & 5 & $\begin{array}{l}\text { Depois de nove meses do óvulo fecundado } \\
\text { nasce uma criança/ ele penetra no óvulo e } \\
\text { meses depois nasce o bebê/ O homem e a } \\
\text { mulher têm relações e conforme o tempo } \\
\text { passa a barriga da mulher cresce e nasce } \\
\text { um bebê/ os elementos se fundem/ a } \\
\text { barriga grande/ocorre a copulação entre o } \\
\text { homem e a mulher, daí o espermatozóide } \\
\text { fecunda o óvulo }\end{array}$ \\
\hline 22 & $\begin{array}{lr}\text { Verdura } & \text { se } \\
\text { transforma } & \text { em } \\
\text { salada/ verdura } & \\
\end{array}$ & 2 & 1 & & $\begin{array}{l}\text { Depois de lavar, cortar e temperar, a } \\
\text { verdura vira salada/ nós plantamos, } \\
\text { regamos, colhemos e depois a consumimos }\end{array}$ \\
\hline 23 & $\begin{array}{l}\text { Pólvora/ bomba/ } \\
\text { junção do álcool com } \\
\text { fósforo aceso }\end{array}$ & 3 & & 1 & $\begin{array}{l}\text { Aqueça a pólvora e ela explode/ Explode, } \\
\text { vira gás, fumaça/ como, por exemplo, no } \\
\text { churrasco, a junção do álcool com uma } \\
\text { faísca de fósforo, logo se acende uma } \\
\text { chama de fogo }\end{array}$ \\
\hline 24 & Pão em lanche & 1 & & & $\begin{array}{l}\text { Recheia o pão com ingredientes que vira } \\
\text { lanche }\end{array}$ \\
\hline 25 & Fogo/ Forno a lenha & 6 & 2 & & $\begin{array}{l}\text { Através do fogo nós cozinhamos, temos } \\
\text { iluminação e energia, pois é através dele } \\
\text { que temos luz, energia, através dele } \\
\text { também podemos cozinhar, fritar os } \\
\text { alimentos/ transformar objetos/ } \\
\text { Antigamente, para cozinhar, fritar, etc. } \\
\text { precisava de um forno a lenha e agora } \\
\text { utilizamos o fogão, existe o forno a lenha, } \\
\text { etc. }\end{array}$ \\
\hline 26 & \begin{tabular}{lrr} 
Corpo & \multicolumn{2}{c}{ humano/ } \\
nosso corpo/ ser \\
humano/
\end{tabular} & 6 & 23 & 11 & $\begin{array}{l}\text { A partir dos } 12 \text { anos o nosso corpo sofre } \\
\text { uma grande mudança/ quando somos } \\
\text { crianças é uma coisa e quando vamos } \\
\text { crescendo o nosso corpo fica diferente, ele } \\
\text { se transforma/ Quando nós nascemos } \\
\text { somos um bebê, mas com o passar do } \\
\text { tempo crescemos e ficamos grandes/ } \\
\text { quando nós nascemos, nascemos pequenos } \\
\text { e com o passar do tempo, nós crescemos de } \\
\text { tamanho, aumentando nosso peso, etc/ } \\
\text { quando somos pequenos nossos ossos são } \\
\text { pequenos ao crescermos nossos ossos } \\
\text { ficam maiores, assim ficamos maiores/ } \\
\text { Aparência / em um dia nós somos } \\
\text { espermatozóides em outro dia nós somos } \\
\text { bebê, em outro somos adultos/ de criança } \\
\text { para homem/ se desenvolve por inteiro/ } \\
\text { crescimento dos dentes, cabelos, unhas, } \\
\text { pêlos, o corpo em geral/ se transforma ao } \\
\text { longo do tempo/ o gato nasce pequeno e } \\
\text { depois se desenvolve/ fisionomia diferente }\end{array}$ \\
\hline
\end{tabular}

\section{Continua}




\section{Turmas ( $n^{o}$ de alunos): evocações em \%}

\begin{tabular}{|c|c|c|c|c|c|}
\hline$N^{o}$ & Evocações & $1 A(24)$ & $1 B(32)$ & $1 C(27)$ & $\begin{array}{l}\text { Justificativa de reconhecimento da } \\
\text { transformação }\end{array}$ \\
\hline 27 & $\begin{array}{l}\text { Borboleta/ Lagarto + } \\
\text { casulo = borboleta/ } \\
\text { metamorfose da } \\
\text { lagarta/ metamorfose } \\
\text { da borboleta }\end{array}$ & 5 & & 8 & $\begin{array}{l}\text { De um lagarto, depois de sair do casulo, } \\
\text { vira borboleta/ Mudança de cor, forma, } \\
\text { tamanho e peso/ forma casulo, a lagarta } \\
\text { passa por uma mudança e sai a borboleta }\end{array}$ \\
\hline 28 & $\begin{array}{l}\text { Fotossíntese/ } \\
\text { Respiração }\end{array}$ & 6 & 1 & 1 & $\begin{array}{l}\text { Mudou a matéria, o gás carbônico em } \\
\text { oxigênio/ Inspira oxigênio e solta gás } \\
\text { carbônico/ troca de oxigênio por gás } \\
\text { carbônico/ as plantas absorvem o gás } \\
\text { carbônico que combinado com a água, e } \\
\text { ambos são transformados em glicose e } \\
\text { oxigênio }\end{array}$ \\
\hline 29 & Digestão & 1 & & & $\begin{array}{l}\text { Separação de material transformando em } \\
\text { várias outras substâncias }\end{array}$ \\
\hline 30 & $\begin{array}{l}\text { Amadurecimento de } \\
\text { uma fruta/ fruta/ } \\
\text { apodrecimento da } \\
\text { fruta/ uma maçã } \\
\text { podre/ um abacate/ } \\
\text { madeira/ verdura/ } \\
\text { uma batata estragada/ } \\
\text { carne podre/ comida } \\
\text { estragada/ limão/ } \\
\text { suco/laranja }\end{array}$ & 4 & 22 & 19 & $\begin{array}{l}\text { Ela estava verde e ao passar de } 2 \text { dias ela } \\
\text { fica amarela/ mudar de cor e ficar mole; } \\
\text { amolecer/ depois de alguns dias ela } \\
\text { apodrece/ o fruto está maduro quando não } \\
\text { consumido passa por uma reação química/ } \\
\text { porque a maçã boa é vermelha e durinha, } \\
\text { quando ela estraga fica preta e mole/ Ele é } \\
\text { duro e com o tempo amolece/ Com o } \\
\text { passar do tempo ela apodrece/ apodrece se } \\
\text { não usar/ notamos pela coloração/ Ela fede } \\
\text { e tem uma consistência ruim/ se você } \\
\text { preparar a comida e deixá-la destampada as } \\
\text { bactérias fazem ela azedar/ se não } \\
\text { consumir azeda/ a laranja cria um fungo e } \\
\text { fica cheirando mal }\end{array}$ \\
\hline 31 & $\begin{array}{l}\text { Transformação de } \\
\text { um lápis/ lápis }\end{array}$ & 1 & 2 & 1 & $\begin{array}{l}\text { Quando nós o apontamos fica pequeno/ de } \\
\text { tanto apontar acaba }\end{array}$ \\
\hline 32 & $\begin{array}{l}\text { Banho/ tomar banho/ } \\
\text { sabonete }\end{array}$ & 2 & 1 & & $\begin{array}{l}\text { Nós estamos fedidos e depois ficamos } \\
\text { cheirosos/ a pessoa entra suja, mas sai } \\
\text { limpa depois/ quando usamos o sabonete } \\
\text { ele acaba }\end{array}$ \\
\hline 33 & Saborear & 1 & & & $\begin{array}{l}\text { Sentir o sabor do pão que antes estava } \\
\text { inteiro e depois ele foi digerido }\end{array}$ \\
\hline 34 & $\begin{array}{l}\text { Ingerir álcool/ bebida } \\
\text { alcoólica/ } \\
\text { Aguardente + limão } \\
+ \text { açúcar + gelo = } \\
\text { "caipirinha" }\end{array}$ & 3 & 4 & & $\begin{array}{l}\text { Mau hálito, ressaca, nervoso, euforia, } \\
\text { embriaguês, dor de cabeça/ pessoas } \\
\text { alegres/ muda o sabor e a temperatura }\end{array}$ \\
\hline 35 & $\begin{array}{l}\text { Pular/ correr/ } \\
\text { atividade física/ pular } \\
\text { corda/ jogar futebol/ } \\
\text { obesidade/ } \\
\text { emagrecendo/ fazer } \\
\text { regime }\end{array}$ & 2 & 8 & 1 & $\begin{array}{l}\text { Transpiração; cansaço; dor muscular; } \\
\text { respiração ofegante/ transpiração, perda de } \\
\text { peso/ o ser vivo estava parado e se } \\
\text { movimenta se locomove/ antes a pessoa era } \\
\text { magra/ fazendo exercícios físicos } \\
\text { emagrecer }\end{array}$ \\
\hline
\end{tabular}




\section{Turmas ( $n^{o}$ de alunos): evocações em \%}

\begin{tabular}{|c|c|c|c|c|c|}
\hline$N^{o}$ & Evocações & $1 A(24)$ & $1 B(32)$ & $1 C(27)$ & $\begin{array}{l}\text { Justificativa de reconhecimento da } \\
\text { transformação }\end{array}$ \\
\hline 36 & 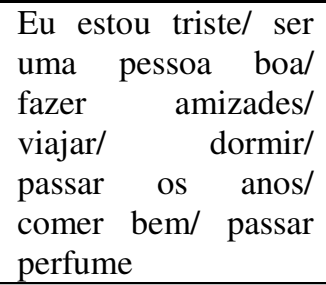 & 2 & & 7 & $\begin{array}{l}\text { Porque tinha duas festas para ir ao mesmo } \\
\text { horário/ uma pessoa feliz/ ter amigos/ } \\
\text { conhecer coisas novas/ descansar/ ficar com } \\
\text { mais idade/ estar satisfeito/ cheirar bem }\end{array}$ \\
\hline 37 & Lavar as frutas & 2 & & & Que já não tinha mais bicho \\
\hline 38 & Lua/ Sol/ dia & 1 & 1 & 1 & $\begin{array}{l}\text { Tem vários tipos de lua, cheia, minguante, } \\
\text { nova, etc/ quando está posto é dia e quando } \\
\text { some fica noite/ logo ao amanhecer o dia } \\
\text { vai clareando, certa hora os sol nasce e no } \\
\text { final da tarde ele se põe e se torna noite }\end{array}$ \\
\hline 39 & Estação & 1 & & & Inverno, verão, outono e primavera \\
\hline 40 & $\begin{array}{lll}\begin{array}{l}\text { Lápis } \\
\text { desenho }\end{array} & \text { de } & \text { cor/ }\end{array}$ & 2 & 1 & & Colorir papel/ a pessoa pode colorir \\
\hline 41 & $\begin{array}{l}\text { Linha }+ \text { máquina de } \\
\text { costura = tecido/ } \\
\text { tecido/ criação de } \\
\text { roupas }\end{array}$ & 1 & 2 & 1 & $\begin{array}{l}\text { A linha vai se juntando, formando um } \\
\text { material consistente/ Foi cortado, costurado } \\
\text { e aí houve a transformação/ era só um } \\
\text { tecido e foi confeccionado, até virar roupas }\end{array}$ \\
\hline 42 & $\begin{array}{l}\text { Cal }+ \text { cimento }+ \\
\text { areia }+ \text { água }=\text { massa } \\
\text { grudenta }\end{array}$ & 1 & & & Muda o estado, a cor e o cheiro \\
\hline 43 & $\begin{array}{l}\text { Banana }+ \text { maçã }+ \\
\text { manga }+ \text { mamão }+ \\
\text { laranja }=\text { salada de } \\
\text { frutas/ vitamina/ } \\
\text { leite, açúcar e frutas }\end{array}$ & 2 & & 3 & $\begin{array}{l}\text { A união destes modifica o sabor e a cor de } \\
\text { tudo/ Coloca as frutas e bate no } \\
\text { liquidificador/ união entre os ingredientes = } \\
\text { vitamina/ mistura de frutas em uma coisa só }\end{array}$ \\
\hline 44 & $\begin{array}{l}\text { Mudanças no tempo/ } \\
\text { o tempo chuvoso/ } \\
\text { tempo nublado }\end{array}$ & 1 & 3 & & $\begin{array}{l}\text { Ao ver as temperaturas quentes e frias } \\
\text { mudarem/pelas nuvens escuras/ o céu } \\
\text { carregado }\end{array}$ \\
\hline 45 & $\begin{array}{l}\text { Gasolina utilizada } \\
\text { nos veículos/ álcool }\end{array}$ & 1 & & 7 & $\begin{array}{l}\text { É uma mistura de vários compostos (o } \\
\text { octano, composto formado por carbono e } \\
\text { hidrogênio...)/ no carro sua transformação é } \\
\text { rápida se transformando em fumaça/ entra } \\
\text { líquida e sai como fumaça/ o carro andou } \\
\text { pela combustão }\end{array}$ \\
\hline 46 & $\begin{array}{lll}\text { Garrafa de vinho } \\
\text { fechada }\end{array}$ & 1 & & & $\begin{array}{l}\text { Se tornará vinagre o que pode ser perigoso } \\
\text { a saúde }\end{array}$ \\
\hline 47 & Abelha em mel & 1 & & & Produz o mel \\
\hline 48 & Uva em vinho & 1 & & & Amassando a uva e fazendo o vinho \\
\hline 49 & Ferro & 1 & & & $\begin{array}{l}\text { Ferrugem: por ele se quebrar com } \\
\text { facilidade e apodrecer }\end{array}$ \\
\hline 50 & Giz (usar) & & 19 & & $\begin{array}{l}\text { Depois de todo gasto ele vira pó/ depois de } \\
\text { ele se transformar em gesso ele vira pó/ ao } \\
\text { observarmos um giz antes de usá-lo vemos } \\
\text { ele em estado sólido, logo depois que } \\
\text { começamos a escrever ele se torna pó/ } \\
\text { conforme escreve se desfaz }\end{array}$ \\
\hline
\end{tabular}




\section{Turmas ( $n^{o}$ de alunos): evocações em \%}

\begin{tabular}{|c|c|c|c|c|c|}
\hline$N^{o}$ & Evocações & $1 A(24)$ & $1 B(32)$ & $1 C(27)$ & $\begin{array}{l}\text { Justificativa de reconhecimento da } \\
\text { transformação }\end{array}$ \\
\hline
\end{tabular}

Principalmente nos homens a voz muda/

51 Fala/ falar/ verdade

15 quando somos pequenos a nossa fala fica fina e quando ficamos maiores a nossa voz engrossa/ emissão de sons/ é muito importante a pessoa falar

$52 \begin{aligned} & \text { Cabelo/ cortar } \\ & \text { cabelo }\end{aligned}$ o 16

Com o passar dos dias o cabelo cresce/quando cortamos, ele cresce novamente/ a pessoa pode mudar de cor/ de cabelo grande para cabelo curto 53 Unhas/ cortar as

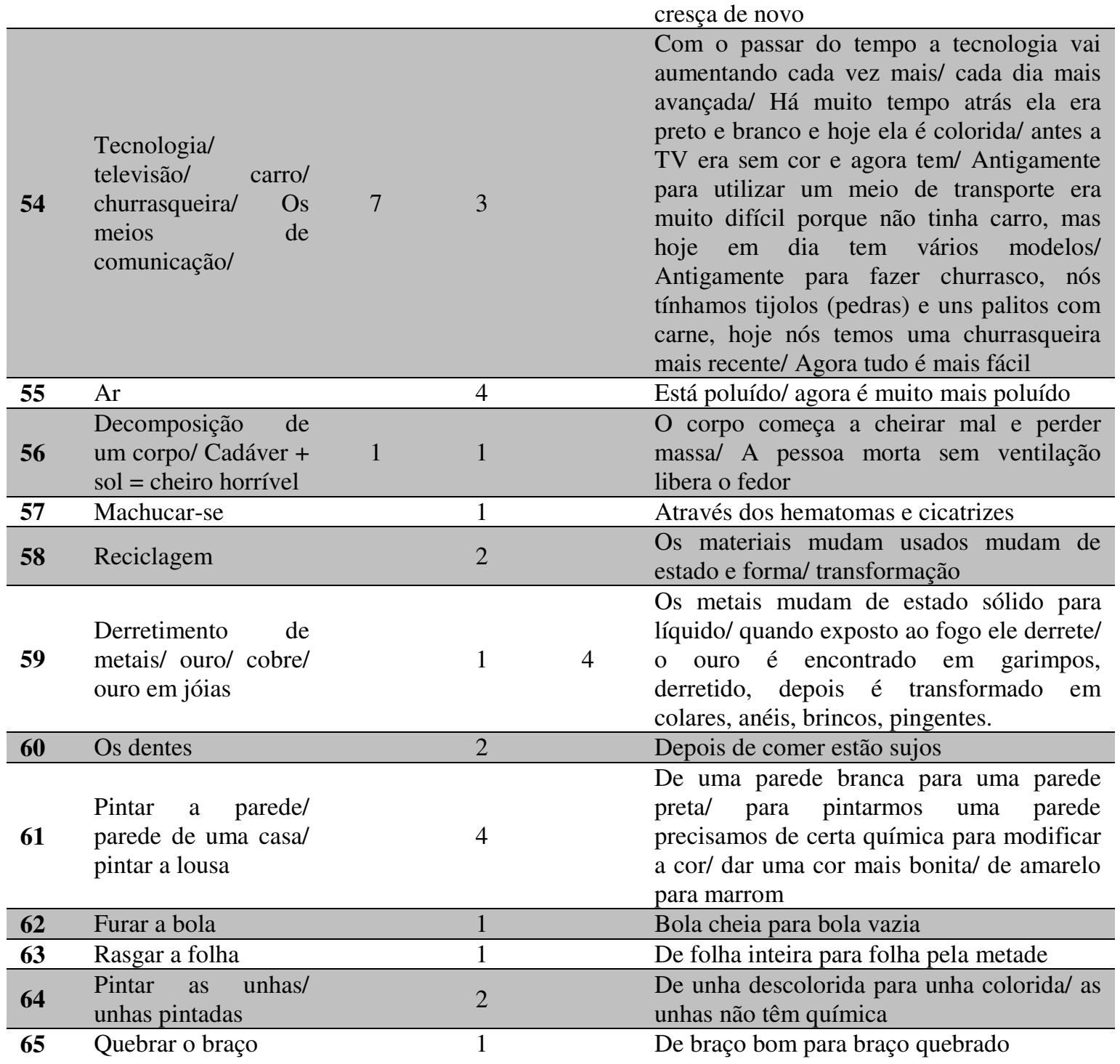
dos dias ela cresce/ nós temos que ir cortando/ de unha grande para unha curta/ cortando a unha você faz com que ela cresça de novo

Com o passar do tempo a tecnologia vai avançada/ Há muito tempo atrás ela era preto e branco e hoje ela é colorida/ antes a TV era sem cor e agora tem/ Antigamente para utilizar um meio de transporte era carro, mas Antigamente para fazer churrasco, nós Está poluído/ agora é muito mais poluído Através dos hematomas e cicatrizes estado e forma/ transformação

Os metais mudam de estado sólido para líquido/ quando exposto ao fogo ele derrete/ derretido, depois é transformado em Depois de comer estão sujo preta/ para pintarmos uma parede para modificar para marrom

Que no mesmo caso do cabelo ao passar 


\section{Conclusão}

\section{Turmas ( $n^{o}$ de alunos): evocações em \%}

\begin{tabular}{|c|c|c|c|c|c|}
\hline$N^{o}$ & Evocações & $1 A(24)$ & $1 B(32)$ & $1 C(27)$ & $\begin{array}{l}\text { Justificativa de reconhecimento da } \\
\text { transformação }\end{array}$ \\
\hline 66 & Consertar relógio & & 1 & & $\begin{array}{l}\text { De relógio quebrado para relógio } \\
\text { funcionando }\end{array}$ \\
\hline 67 & Tomar sol/ pele & & 11 & & $\begin{array}{l}\text { De pele clara para pele escura/ com os raios } \\
\text { do sol, faz com que mude a cor }\end{array}$ \\
\hline 68 & $\begin{array}{l}\text { Produtos de limpeza/ } \\
\text { limpar a casa }\end{array}$ & & 1 & 1 & $\begin{array}{l}\text { Para termos a casa limpa é preciso muitos } \\
\text { produtos que contém química, o que limpa, } \\
\text { o que dá cheira e muitos outros }\end{array}$ \\
\hline 69 & Objeto & & 4 & & Com o passar do tempo ele vai envelhecer \\
\hline 70 & Morte & & 1 & & Pessoa antes era viva \\
\hline 71 & Usar drogas & & & 4 & $\begin{array}{l}\text { Perda momentânea da consciência, } \\
\text { perturbações, alucinações }\end{array}$ \\
\hline 72 & Tinta & & & 2 & $\begin{array}{l}\text { Se você deixar a tinta descansar ela pode } \\
\text { ficar dura com uma casquinha }\end{array}$ \\
\hline 73 & Água suja/ de um rio & & & 2 & $\begin{array}{l}\text { Jogando esgoto na água tem micróbios e é } \\
\text { um veículo de doenças; em vez de cristalina } \\
\text { ela é preta/ um rio limpo e um rio sujo }\end{array}$ \\
\hline 74 & Roupa molhada & & & 1 & $\begin{array}{l}\text { Se a roupa está molhada e ficar muito } \\
\text { tempo parada, a camisa vai ficar com mofo }\end{array}$ \\
\hline 75 & $\begin{array}{l}\text { Gel de cabelo/ creme } \\
\text { de cabelo }\end{array}$ & & & 2 & Se deixarmos sem tampa ele irá secar \\
\hline 76 & Café & & & 1 & $\begin{array}{l}\text { É um grão que é colhido, tratado e } \\
\text { processado e vira pó }\end{array}$ \\
\hline 77 & $\begin{array}{l}\text { Naftalina/ gesso/ } \\
\text { chuva }\end{array}$ & & & 4 & $\begin{array}{l}\text { Passa do estado sólido direto para o gasoso/ } \\
\text { transformação do estado líquido para o } \\
\text { sólido/ vapor de água se transforma em } \\
\text { chuva }\end{array}$ \\
\hline 78 & O sal na água do mar & & & 1 & $\begin{array}{l}\text { Quando ele é retirado do mar ele vai para } \\
\text { salina é tratado e vai para as pessoas } \\
\text { utilizarem }\end{array}$ \\
\hline 79 & Estudar & & & 2 & Progredir \\
\hline 80 & Tijolos & & & 1 & Casa, prédios, etc \\
\hline
\end{tabular}




\section{Turmas}

\begin{tabular}{|c|c|c|c|c|}
\hline $\mathbf{N}^{\mathbf{0}}$ & Evocação & $\mathbf{1 A}$ & 1B & Justificativa de reconhecimento \\
\hline 1 & $\begin{array}{l}\text { Decomposição de } \\
\text { um organismo vivo }\end{array}$ & $\mathrm{X}$ & & $\begin{array}{l}\text { Ficar fedido/ cheiro/ vermes/ cor/ urubus quem ficam ao } \\
\text { redor }\end{array}$ \\
\hline 2 & $\begin{array}{l}\text { Cinzas/ queimou } \\
\mathrm{papel} / \mathrm{papel}\end{array}$ & $\mathrm{X}$ & $\mathrm{X}$ & $\begin{array}{l}\text { Não pode voltar a ser papel/ desintegrou/ escureceu/ cor/ } \\
\text { fogo/ cheiro/ transformação da madeira/ tira a celulose } \\
\text { da madeira/ formato }\end{array}$ \\
\hline 3 & Digestão & $\mathrm{X}$ & & Quebra de moléculas/ ácido estomacal/ suco gástrico \\
\hline 4 & $\begin{array}{l}\text { Planta crescendo/ } \\
\text { desenvolvimento } \\
\text { das plantas }\end{array}$ & $\mathrm{X}$ & $\mathrm{X}$ & $\begin{array}{l}\text { Desenvolvimento/ fotossíntese/ metamorfose/ } \\
\text { respiração/ liberação de oxigênio/ germinação/ captação } \\
\text { de gás carbônico/ absorção de água e sais minerais/ cor/ } \\
\text { estrutura/ porque uma semente vira uma árvore }\end{array}$ \\
\hline 5 & $\begin{array}{l}\text { Cicatrização de uma } \\
\text { ferida }\end{array}$ & $\mathrm{X}$ & & $\begin{array}{l}\text { Restauração das células epiteliais/ cor do machucado/ } \\
\text { formação de pus/ anticorpos/febre/ hematomas }\end{array}$ \\
\hline 6 & Gelatina & $\mathrm{X}$ & & Endurecimento/ consistência/ gosto/ cor/ transparência \\
\hline 7 & Pão/ fazer um bolo & $\mathrm{X}$ & $\mathrm{X}$ & $\begin{array}{l}\text { Crescimento/ fermentação/ temperatura/ consistência / } \\
\text { no forno faz o bolo crescer/ no forno faz o bolo crescer/ } \\
\text { muda a cor e o sabor }\end{array}$ \\
\hline 8 & Bolor/mofo & $\mathrm{X}$ & & Cor/ cheiro/ gosto/ fungos \\
\hline 9 & Cerveja & $\mathrm{X}$ & & Fermentação/ cor álcool/gases \\
\hline 10 & $\begin{array}{l}\text { Comprimido } \\
\text { efervescente }\end{array}$ & & $\mathrm{X}$ & $\begin{array}{l}\text { Bolinhas/ quando coloca na água dissolve/ a massa vira } \\
\text { pó/ fica efervescente }\end{array}$ \\
\hline 11 & $\begin{array}{l}\text { Funcionamento do } \\
\text { automóvel }\end{array}$ & & $\mathrm{X}$ & Queimação do combustível/ fumaça do escapamento \\
\hline 12 & Milho de pipoca & & $\mathrm{X}$ & Estoura/ muda de cor/ macio e crocante \\
\hline 13 & Cozinhar carne & & $\mathrm{X}$ & Deixa de ser dura e fica cozida/ sabor \\
\hline 14 & Fritar ovos & & $\mathrm{X}$ & $\begin{array}{l}\text { Era meio líquido e fica sólido/ oleoso/ cremoso/ fica } \\
\text { cozido/ sabor/cor }\end{array}$ \\
\hline 15 & Respiração & & $\mathrm{X}$ & Inspiro oxigênio e expiro gás carbônico/ respira poluição \\
\hline 16 & Fazer escova & & $\mathrm{X}$ & $\begin{array}{l}\text { Alisa o cabelo/ agride os fios/ fazer hidratação com } \\
\text { queratina e ceramida para restaurar os fios agredidos }\end{array}$ \\
\hline
\end{tabular}


ANEXO C4 - Tabela coletiva de evocações de transformações do ano de 2007

\begin{tabular}{|c|c|c|c|c|c|}
\hline \multicolumn{6}{|c|}{ Turmas } \\
\hline$N^{o}$ & Evocação & $1 A$ & $1 B$ & $1 C$ & Justificativa de reconhecimento \\
\hline 1 & $\begin{array}{l}\text { Esquentar água para } \\
\text { preparar o café/ } \\
\text { colocar água no } \\
\text { congelador, vai } \\
\text { virar gelo, formação } \\
\text { do gelo }\end{array}$ & $X$ & & $\mathrm{X}$ & $\begin{array}{l}\text { Presença de vapor; fervendo, antes a água estava } \\
\text { numa temperatura ambiente e logo após ficou } \\
\text { quente; a água era líquida e ficou sólida }\end{array}$ \\
\hline 2 & $\begin{array}{l}\text { O ovo se transforma } \\
\text { em galinha }\end{array}$ & $\mathrm{X}$ & & & $\begin{array}{l}\text { O ovo foi chocado por outra galinha, se quebrou e } \\
\text { deu origem a outra galinha }\end{array}$ \\
\hline 3 & $\begin{array}{l}\text { Fazendo pão/ } \\
\text { fermentação do pão }\end{array}$ & $\mathrm{X}$ & $\mathrm{X}$ & & $\begin{array}{l}\text { Misturando ovos, farinha, açúcar, sal, fermento e } \\
\text { leite, levar ao forno para aquecer, para o fermento } \\
\text { agir e assar o pão/ era uma massa macia, pequena } \\
\text { que foi aquecida, cresceu e ficou crocante com } \\
\text { casca }\end{array}$ \\
\hline 4 & Saborear o pão & $\mathrm{X}$ & & & $\begin{array}{l}\text { Sentir o sabor do pão que antes estava inteiro e } \\
\text { depois ele foi digerido }\end{array}$ \\
\hline 5 & $\begin{array}{l}\text { Amadurecimento da } \\
\text { fruta }\end{array}$ & $\mathrm{X}$ & & & Mudar de cor e ficar mole; amolecer \\
\hline 6 & Queimar papel & $\mathrm{X}$ & & & $\begin{array}{l}\text { O papel era branco, estava inteiro e depois virou } \\
\text { cinzas }\end{array}$ \\
\hline 7 & Ingerir álcool & $\mathrm{X}$ & & & $\begin{array}{l}\text { Mau hálito, ressaca, nervoso, euforia, embriaguês, } \\
\text { dor de cabeça, etc. }\end{array}$ \\
\hline 8 & Tomar remédio & $\mathrm{X}$ & & & $\begin{array}{l}\text { Quando tomamos o remédio nosso organismo sofre } \\
\text { uma reação e quando não rejeitado melhoramos }\end{array}$ \\
\hline 9 & Pular corda & $\mathrm{X}$ & & & Transpiração, cansaço, dor muscular \\
\hline 10 & Tomar sol & & $\mathrm{X}$ & & Mudou a cor da pele; a pele de clara ficou escura \\
\hline 11 & $\begin{array}{l}\text { Crescimento da } \\
\text { planta }\end{array}$ & & $\mathrm{X}$ & & $\begin{array}{l}\text { Era uma semente e depois de um tempo se tornou } \\
\text { uma planta, uma árvore }\end{array}$ \\
\hline 12 & Correr & & $\mathrm{X}$ & & $\begin{array}{l}\text { O ser vivo estava parado e se movimentou se } \\
\text { locomoveu }\end{array}$ \\
\hline 13 & $\begin{array}{l}\text { Desenvolvimento do } \\
\text { corpo/ } \\
\text { desenvolvimento do } \\
\text { ser humano }\end{array}$ & & $\mathrm{X}$ & $X$ & $\begin{array}{l}\text { Crescimento dos dentes, cabelos, unhas, pêlos, } \\
\text { ossos, o corpo em geral/ nascem, crescem, a maioria } \\
\text { se reproduz, envelhecem e morrem }\end{array}$ \\
\hline 14 & $\begin{array}{l}\text { Pintar o cabelo/ } \\
\text { tingimento do cabelo }\end{array}$ & & $\mathrm{X}$ & $\mathrm{X}$ & $\begin{array}{l}\text { Mudou a cor do cabelo/ ocorre uma química, era de } \\
\text { uma cor e ficou de outra, muda o pigmento do } \\
\text { cabelo }\end{array}$ \\
\hline 15 & Reciclagem do papel & & $\mathrm{X}$ & & $\begin{array}{l}\text { O papel estava usado, rasgado, daí ele passa por } \\
\text { uma produção que é o processo de reciclagem e se } \\
\text { transforma em um papel novo }\end{array}$ \\
\hline 16 & $\begin{array}{l}\text { Estourar milho de } \\
\text { pipoca }\end{array}$ & & $\mathrm{X}$ & & $\begin{array}{l}\text { Antes ele era um caroço, era duro, amarelo e ficou } \\
\text { branco, grande, macio, crocante }\end{array}$ \\
\hline 17 & $\begin{array}{l}\text { Cortar o cabelo da } \\
\text { Tiffany }\end{array}$ & & $X$ & & $\begin{array}{l}\text { A Tiffany foi ao cabeleireiro e cortou o cabelo que } \\
\text { era longo, grande e ficou careca }\end{array}$ \\
\hline 18 & Bater em uma pessoa & & $\mathrm{X}$ & & $\begin{array}{l}\text { A pessoa estava fisicamente inteira, sem lesões e } \\
\text { depois o corpo se movimentou, ficou roxo } \\
\text { (hematomas) e dolorido }\end{array}$ \\
\hline 19 & Fritar ovos & & & $\mathrm{X}$ & $\begin{array}{l}\text { O ovo estava líquido, adquiriu consistência, sabor, } \\
\text { cor, cheiro }\end{array}$ \\
\hline . & & & & & \\
\hline
\end{tabular}




\section{Conclusão}

\section{Turmas}

\begin{tabular}{|c|c|c|c|c|}
\hline$N^{o}$ & Evocação & $1 A$ & $1 C$ & Justificativa de reconhecimento \\
\hline 20 & $\begin{array}{l}\text { Metamorfose } \\
\text { lagarta }\end{array}$ & & $\mathrm{X}$ & $\begin{array}{l}\text { Forma o casulo, a lagarta passa por uma mudança e } \\
\text { sai a borboleta. }\end{array}$ \\
\hline 21 & $\begin{array}{l}\text { Fecundação } \\
\text { óvulo }\end{array}$ & & $X$ & $\begin{array}{l}\text { Ocorre a copulação entre o homem e a mulher, daí o } \\
\text { espermatozóide fecunda o óvulo }\end{array}$ \\
\hline 22 & Cozimento do arroz & & $X$ & $\begin{array}{l}\text { Estava cru, duro, mudou o gosto, ele cresce, muda a } \\
\text { textura e a consistência }\end{array}$ \\
\hline 23 & $\begin{array}{l}\text { Formação; preparo } \\
\text { da gelatina }\end{array}$ & & $\mathrm{X}$ & $\begin{array}{l}\text { Antes era um pó que se dissolveu na água quente e } \\
\text { foi refrigerado, criando uma consistência gelatinosa }\end{array}$ \\
\hline 24 & Usar drogas & & $X$ & $\begin{array}{l}\text { Perda momentânea da consciência, perturbações, } \\
\text { alucinações }\end{array}$ \\
\hline 25 & Fazer papel & & $X$ & $\begin{array}{l}\text { Desmatar, derrubar a árvore e extrair a celulose da } \\
\text { madeira e levar para a fábrica para produzir o papel }\end{array}$ \\
\hline
\end{tabular}


ANEXO D - Tabelas construídas para análise das mensagens dos educandos referenciando o conceito de transformação dos materiais, em suas varas fases e estágios

ANEXO D1 - Tabelas individual e coletiva organizadas para observação das etapas de formação do conceito de transformação em alunos do ano letivo de 2006, conforme a primeira atividade analisada.

\begin{tabular}{|c|c|c|c|}
\hline Fases & Estágios & $\begin{array}{l}\text { Justificativas de reconhecimento de ocorrência de } \\
\text { transformações em } 2006 \text { (Tabela Individual) }\end{array}$ & TOTAL \\
\hline \multirow{34}{*}{ 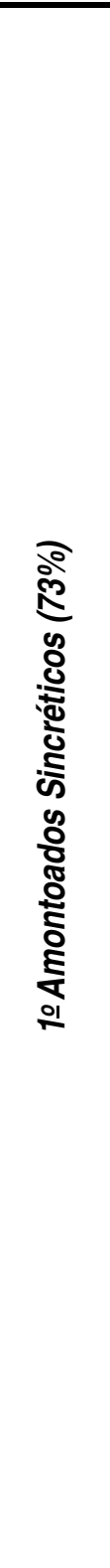 } & \multirow{17}{*}{ 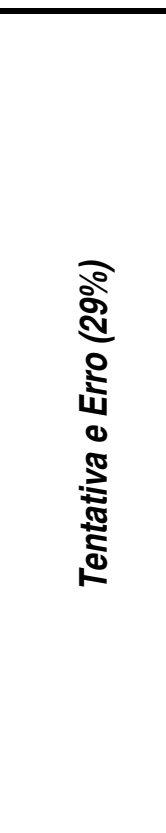 } & Presença de álcool/ Presença de oxigênio/ Presença de umidade & 3 \\
\hline & & $\begin{array}{l}\text { Oxidação/ Fotossíntese/ Germinação/ Respiração/ Decomposição/ } \\
\text { Desenvolvimento }\end{array}$ & 6 \\
\hline & & Combustão/ presença de oxigênio misturado com combustível & 2 \\
\hline & & Pela alta temperatura, presença de fogo, de calor, mudança de estado físico & 1 \\
\hline & & $\begin{array}{l}\text { Quebra de moléculas, transformar bolo alimentar em nutrientes/ diluição dos } \\
\text { alimentos/ comer comida }\end{array}$ & 1 \\
\hline & & Glóbulos brancos/ formação de pus & 2 \\
\hline & & $\begin{array}{l}\text { Enfraquecimento dos fios/agride os fios/queratina e ceramida restauram os } \\
\text { fios }\end{array}$ & 3 \\
\hline & & Ferver água/ evaporação & 2 \\
\hline & & A fruta fica podre & 1 \\
\hline & & Transformação da madeira em celulose & 1 \\
\hline & & Mudança de casca & 1 \\
\hline & & Processo que pega o petróleo e passa a ficar combustível & 1 \\
\hline & & O fermento faz crescer/ o forno faz crescer/ No forno ele cresce & 3 \\
\hline & & Respira poluição/ poluição & 2 \\
\hline & & Tira a celulose da madeira para fazer papel & 1 \\
\hline & & Mudança de oxigênio para gás carbônico & 1 \\
\hline & & Sólido, líquido e gasoso/ Foi do líquido para o sólido & 2 \\
\hline & \multirow{17}{*}{ 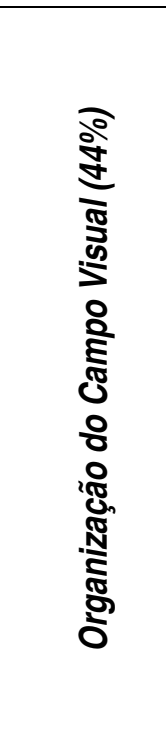 } & Colocar fogo e começar o aparecimento de cinzas & 1 \\
\hline & & Mudança de cor/ cor/ fica transparente & 15 \\
\hline & & Fumaça/ fumaça do escapamento & 3 \\
\hline & & Derrete & 1 \\
\hline & & $\begin{array}{l}\text { Consistência/ muda a consistência/ fica duro/ crocante/ endurecimento/ fica } \\
\text { murcho/ Estoura }\end{array}$ & 10 \\
\hline & & Gases/ Mistura de gás com líquido/ Faz borbulhar & 4 \\
\hline & & Textura/ mudança de textura/ macio & 3 \\
\hline & & Com o aparecimento de pequenas ferrugens & 1 \\
\hline & & De acordo como você vai apontando ele fica menor & 1 \\
\hline & & Presença de sangue/ formação de casca/ corte na pele/ & 1 \\
\hline & & Presença de insetos e animais & 1 \\
\hline & & Tamanho/ muda o formato/ muda a forma & 4 \\
\hline & & Quando coloca na água se dissolve & 1 \\
\hline & & Quando amassa vira pó & 1 \\
\hline & & Alisa o cabelo & 1 \\
\hline & & Transformação em mesas, cadeiras, camas, palitos & 1 \\
\hline & & TOTAL AMONTOADOS SINCRÉTICOS & 82 \\
\hline
\end{tabular}


Conclusão

\begin{tabular}{|c|c|c|c|}
\hline Fases & Estágios & $\begin{array}{l}\text { Justificativas de reconhecimento de ocorrência de } \\
\text { transformações em } 2006 \text { (Tabela Individual) }\end{array}$ & TOTAL \\
\hline \multirow{13}{*}{ 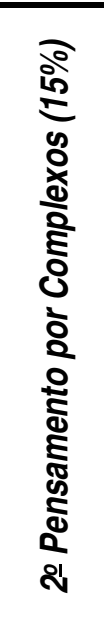 } & \multirow{13}{*}{ 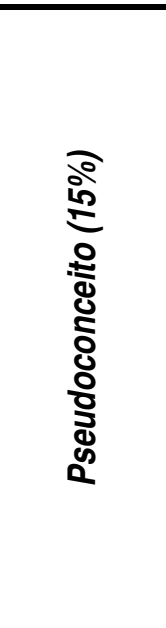 } & Combustão/ Queimação do combustível & 2 \\
\hline & & Fermentação & 1 \\
\hline & & $\begin{array}{l}\text { Água fervendo/ gelo derretendo/ chuva/ água no congelador/ em ambiente } \\
\text { muito frio ela congela, o gelo em ambiente quente derrete }\end{array}$ & 5 \\
\hline & & $\begin{array}{l}\text { Deixa de ser dura, fica cozida e com sabor, muda a cor (tempero), o gosto e } \\
\text { a consistência }\end{array}$ & 1 \\
\hline & & Do papel, vidro, plástico e metais para fazer novos objetos & 1 \\
\hline & & Quando cru era duro, quando cozinha fica mole & 1 \\
\hline & & Liberação de gás & 1 \\
\hline & & Inspira oxigênio e expira gás carbônico & 1 \\
\hline & & Com o passar do tempo & 1 \\
\hline & & Ao ferver a água, ao colocar na água quente começa o cozimento & 1 \\
\hline & & Crescimento & 1 \\
\hline & & De uma semente colocada na terra vira árvore & 1 \\
\hline & & TOTAL PENSAMENTO POR COMPLEXOS & 17 \\
\hline \multirow{4}{*}{\multicolumn{2}{|c|}{ Outros (12\%) }} & Cheiro/ odor/ algumas ficam com cheiro & 7 \\
\hline & & Sabor/ gosto & 5 \\
\hline & & Estrutura & 1 \\
\hline & & TOTAL OUTROS & 13 \\
\hline \multicolumn{3}{|r|}{ TOTAL DE CITAÇÕES } & 112 \\
\hline \multicolumn{3}{|r|}{ TOTAL DE ALUNOS PARTICIPANTES } & 35 \\
\hline
\end{tabular}




\begin{tabular}{|c|c|c|c|}
\hline Fases & Estágios & $\begin{array}{l}\text { Justificativas de reconhecimento de ocorrência de } \\
\text { transformacões em } 2006 \text { (Tabela Coletiva) }\end{array}$ & TOTAL \\
\hline \multirow{50}{*}{ 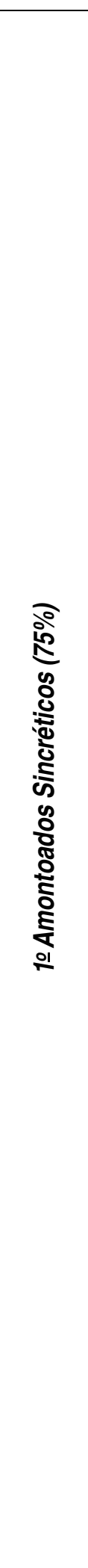 } & \multirow{35}{*}{ 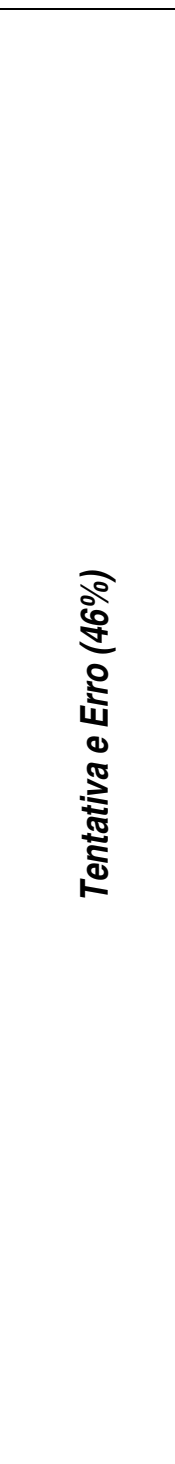 } & Vermes & 1 \\
\hline & & Urubus que ficam ao redor & 1 \\
\hline & & Desintegrou & 1 \\
\hline & & Fogo & 1 \\
\hline & & Transformação da madeira & 1 \\
\hline & & Tira a celulose da madeira & 1 \\
\hline & & Quebra de moléculas & 1 \\
\hline & & Ácido estomacal & 1 \\
\hline & & Suco gástrico & 1 \\
\hline & & Desenvolvimento & 1 \\
\hline & & Fotossíntese & 1 \\
\hline & & Metamorfose & 1 \\
\hline & & Respiração & 1 \\
\hline & & Liberação de oxigênio & 1 \\
\hline & & Germinação & 1 \\
\hline & & Captação de gás carbônico & 1 \\
\hline & & Estrutura & 1 \\
\hline & & Restauração das células epiteliais & 1 \\
\hline & & Formação de pus & 1 \\
\hline & & Anticorpos & 1 \\
\hline & & Febre & 1 \\
\hline & & Temperatura & 1 \\
\hline & & No forno faz o bolo crescer & 1 \\
\hline & & Fungos & 1 \\
\hline & & Álcool & 1 \\
\hline & & A massa vira pó & 1 \\
\hline & & Fica efervescente & 1 \\
\hline & & Macio e crocante & 1 \\
\hline & & Oleoso & 1 \\
\hline & & Cremoso & 1 \\
\hline & & Fica cozido & 1 \\
\hline & & Agride os fios & 1 \\
\hline & & Respira poluição & 1 \\
\hline & & Fazer hidrataccão com queratina e ceramida para restaurar os fios agredidos & 1 \\
\hline & & Absorção de água e sais minerais & 1 \\
\hline & \multirow{15}{*}{ 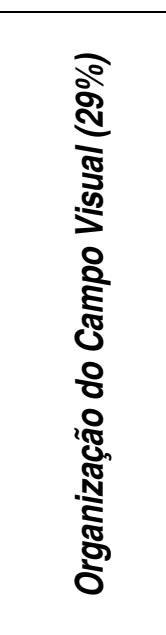 } & Cor & 7 \\
\hline & & Escureceu & 1 \\
\hline & & Formato & 1 \\
\hline & & Cor do machucado & 1 \\
\hline & & Hematomas & 1 \\
\hline & & Consistência & 2 \\
\hline & & Transparência & 1 \\
\hline & & Muda a cor & 2 \\
\hline & & Gases & 1 \\
\hline & & Bolinhas & 1 \\
\hline & & Quando coloca na água dissolve & 1 \\
\hline & & Fumaça do escapamento & 1 \\
\hline & & Estoura & 1 \\
\hline & & Alisa o cabelo & 1 \\
\hline & & TOTAL AMONTOADOS SINCRÉTICOS & 57 \\
\hline
\end{tabular}


Conclusão

\begin{tabular}{|c|c|c|c|c|}
\hline Fases & Estágios & $\begin{array}{l}\text { Justificativas de reconhecimento de } \\
\text { transformações em } 2006 \text { (Tabela Coletiva) }\end{array}$ & ocorrência de & TOTAL \\
\hline \multirow{11}{*}{ 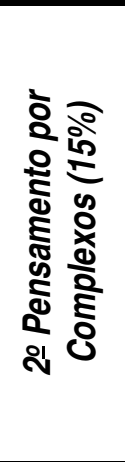 } & \multirow{11}{*}{ 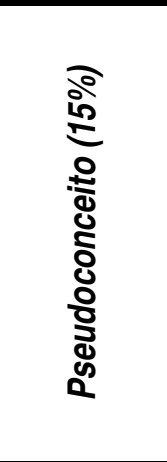 } & Ficar fedido & & 1 \\
\hline & & Não pode voltar a ser papel & & 1 \\
\hline & & Porque uma semente vira uma árvore & & 1 \\
\hline & & Endurecimento & & 1 \\
\hline & & Crescimento & & 1 \\
\hline & & Fermentação & & 2 \\
\hline & & Queimação do combustível & & 1 \\
\hline & & Deixa de ser dura e fica cozida & & 1 \\
\hline & & Era meio líquido e fica sólido & & 1 \\
\hline & & Inspiro oxigênio e expiro gás carbônico & & 1 \\
\hline & & TOTAL PENSAMENTO POR COMPLEXOS & & 11 \\
\hline \multirow{4}{*}{\multicolumn{2}{|c|}{ Outros (10\%) }} & Cheiro & & 3 \\
\hline & & Gosto & & 2 \\
\hline & & Sabor & & 3 \\
\hline & & TOTAL OUTROS & & 08 \\
\hline & & TOTAL DE CITAÇÕES & & 76 \\
\hline
\end{tabular}


ANEXO D2 - Tabelas individual e coletiva organizadas para observação das etapas de formação do conceito de transformação em alunos do ano letivo de 2007, conforme a primeira atividade analisada.

\section{Fases Estágios Justificativas de reconhecimento de ocorrência de TOTAL}

\begin{tabular}{|c|c|c|}
\hline & Após a tintura seu cabelo sofre uma química e muda de cor & 1 \\
\hline & Aqueça a comida & 1 \\
\hline & $\begin{array}{l}\text { Com os temperos e o fogo fazemos uma deliciosa comida/ quando está } \\
\text { cozinhando }\end{array}$ & 2 \\
\hline & $\begin{array}{l}\text { Formação de vários outros elementos/ uma série de processos/ mistura de } \\
\text { coisas/ através de uma técnica e uns tratamentos específicos se fazem o } \\
\text { papel }\end{array}$ & 4 \\
\hline & $\begin{array}{l}\text { Antes era milho, coloca óleo e se transforma em pipoca/ depois de frito vira } \\
\text { pipoca/ quando o milho se abre vira pipoca }\end{array}$ & 3 \\
\hline & O pó, a água quente e fria & 1 \\
\hline & Coloca a roupa suja e sai limpa/ coloca a roupa suja na máquina e sai limpa & 2 \\
\hline & Temperatura efervescente & 1 \\
\hline & $\begin{array}{l}\text { A semente é um frutinho, ao ser colocada na terra ela brota e vira uma flor, } \\
\text { árvore, etc./ em determinado momento ele vira flor/ depois vira uma rosa/ } \\
\text { antes era um botão, agora não é mais/ }\end{array}$ & 4 \\
\hline & Se você jogar uns grãos de feijão na terra vão nascer muitos feijões/ & 1 \\
\hline & Depois de podar & 1 \\
\hline के & $\begin{array}{l}\text { Se a pessoa colocar a planta no sol ela morre e se colocar água ela } \\
\text { sobrevive }\end{array}$ & 1 \\
\hline & Germinação & 1 \\
\hline$\stackrel{8}{z}$ & Elas crescem & 1 \\
\hline$\frac{3}{3}$ & $\begin{array}{l}\text { Virou uma massa, o fungo o fez crescer/ fermento faz o pão crescer/ quando } \\
\text { põe no forno cresce }\end{array}$ & 3 \\
\hline & Leite com farinha e fermento & 1 \\
\hline & Foi preparada, assada e houve a transformação & 1 \\
\hline : & $\begin{array}{l}\text { Depois de ser congelada ela vira gelo/ vira água quando sai da geladeira, } \\
\text { era sólido e ficou líquido/ derrete/ quando não está em vapor é apenas água }\end{array}$ & 4 \\
\hline ह & Era uma água e após tal temperatura virou gelo & 1 \\
\hline & Quando misturados a água se transforma em suco & 1 \\
\hline & É uma transformação & 1 \\
\hline & Após muito tempo prendendo a respiração do pé sai cheiro & 1 \\
\hline & $\begin{array}{l}\text { Alimentação inadequada/ a rejeição do estômago/ quando um alimento não } \\
\text { cai bem/ por comer algo gorduroso e pesado/ embrulhamento no estômago } \\
\text { ou dor de barriga }\end{array}$ & 5 \\
\hline & $\begin{array}{l}\text { Sintetiza novas moléculas, que curam doenças e fortalece a saúde humana/ } \\
\text { a pessoa está doente, toma o remédio e fica boa/ quando põe na água se } \\
\text { dissolve }\end{array}$ & 3 \\
\hline & $\begin{array}{l}\text { Se deixar no copo muito tempo vira queijo/ você faz a transformação de leite } \\
\text { em queijo, do líquido para o sólido/ leite fora da geladeira azeda e coalha }\end{array}$ & 3 \\
\hline & De uma mancha difícil de ser tirada e o líquido tirou & 1 \\
\hline & $\begin{array}{l}\text { Quando o ovo quebra nasce uma galinha/ o ovo foi chocado por outra } \\
\text { galinha e com o calor se quebrou e deu origem a outra galinha ou comida } \\
\text { para nós ou pintinho/ primeiro ele é um ovo comum, depois se transforma } \\
\text { em pintinho }\end{array}$ & 3 \\
\hline
\end{tabular}

A madeira, ao ser extraída das árvores, sofre uma reação química, assim tornando-a esculturas/ ao ser queimada vira pó/ você coloca fogo em uma madeira sólida e se transforma em pó 
Continuação

\begin{tabular}{lllc}
\hline \multirow{2}{*}{ Fases Estágios } & $\begin{array}{l}\text { Justificativas de reconhecimento de ocorrência de } \\
\text { transformaçóes em 2007 (Tabela Individual) }\end{array}$ & TOTAL \\
\hline & $\begin{array}{l}\text { Ele penetra no óvulo e depois de nove meses nasce o bebê/ o homem e a } \\
\text { mulher tem relações e conforme o tempo passa a barriga da mulher cresce } \\
\text { e nasce um bebê/ os elementos se fundem/ a barriga grande/ ocorre a } \\
\text { copulação entre o homem e a mulher, daí o espermatozóide fecunda o óvulo }\end{array}$ & 5 \\
\cline { 2 - 3 } & Aqueça a pólvora e ela explode/ explode, vira gás, fumaça & 2 \\
\hline & Recheia o pão com ingredientes que vira lanche & 1
\end{tabular}

Através do fogo nós cozinhamos, temos iluminação e energia, pois é através dele que temos luz, energia, através dele também podemos cozinhar, fritar os alimentos/ transformar objetos/ Antigamente, para cozinhar, fritar, etc.

precisava de um forno a lenha e agora utilizamos o fogão, existe o forno a lenha, etc.

A partir dos 12 anos o nosso corpo sofre uma grande mudança/ quando somos crianças é uma coisa e quando vamos crescendo o nosso corpo fica diferente, ele se transforma

Em um dia nós somos espermatozóides em outro dia nós somos bebê, em outro somos adultos/de criança para homem/ se desenvolve por inteiro

De um lagarto, depois de sair do casulo, vira borboleta/ forma casulo, a lagarta passa por uma mudança e sai a borboleta

Mudou a matéria, o gás carbônico em oxigênio/ Inspira oxigênio e solta gás carbônico/ troca de oxigênio por gás carbônico

Separação de material transformando em várias outras substâncias

Se você preparar a comida e deixá-la destampada as bactérias fazem ela azedar/ se não consumir azeda/ a laranja cria um fungo e fica cheirando mal

Sentir o sabor do pão que antes estava inteiro e depois ele foi digerido

O ser vivo estava parado o ser vivo estava parado e se movimenta se locomove/ antes a pessoa era magra/ fazendo exercícios físicos emagrecer e se movimenta se locomove/ antes a pessoa era magra/ fazendo exercícios físicos emagrecer

Tem vários tipos de lua, cheia, minguante, nova, etc/ quando está posto é dia e quando some fica noite/ logo ao amanhecer o dia vai clareando, certa hora os sol nasce e no final da tarde ele se põe e se torna noite

Colorir papel/ a pessoa pode colorir

A linha vai se juntando, formando um material consistente

Muda o estado, a cor e o cheiro

A união destes modifica o sabor e a cor de tudo/ Coloca as frutas e bate no liquidificador/ união entre os ingredientes = vitamina/ mistura de frutas em uma coisa só

Ao ver as temperaturas quentes e frias mudarem/pelas nuvens escuras/ 0 céu carregado

O carro andou pela combustão

Ferrugem: por ele se quebrar com facilidade e apodrecer

1

Depois de todo gasto ele vira pó/ depois de ele se transformar em gesso ele vira pól ao observarmos um giz antes de usá-lo vemos ele em estado sólido, logo depois que começamos a escrever ele se torna pó/ conforme escreve se desfaz

Quando cortamos ele cresce novamente

Nós temos que ir cortando/ cortando a unha você faz com que ela cresça de novo

Com o passar do tempo a tecnologia vai aumentando cada vez mais/ cada dia mais avançada

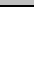

(1)

3


Continuação

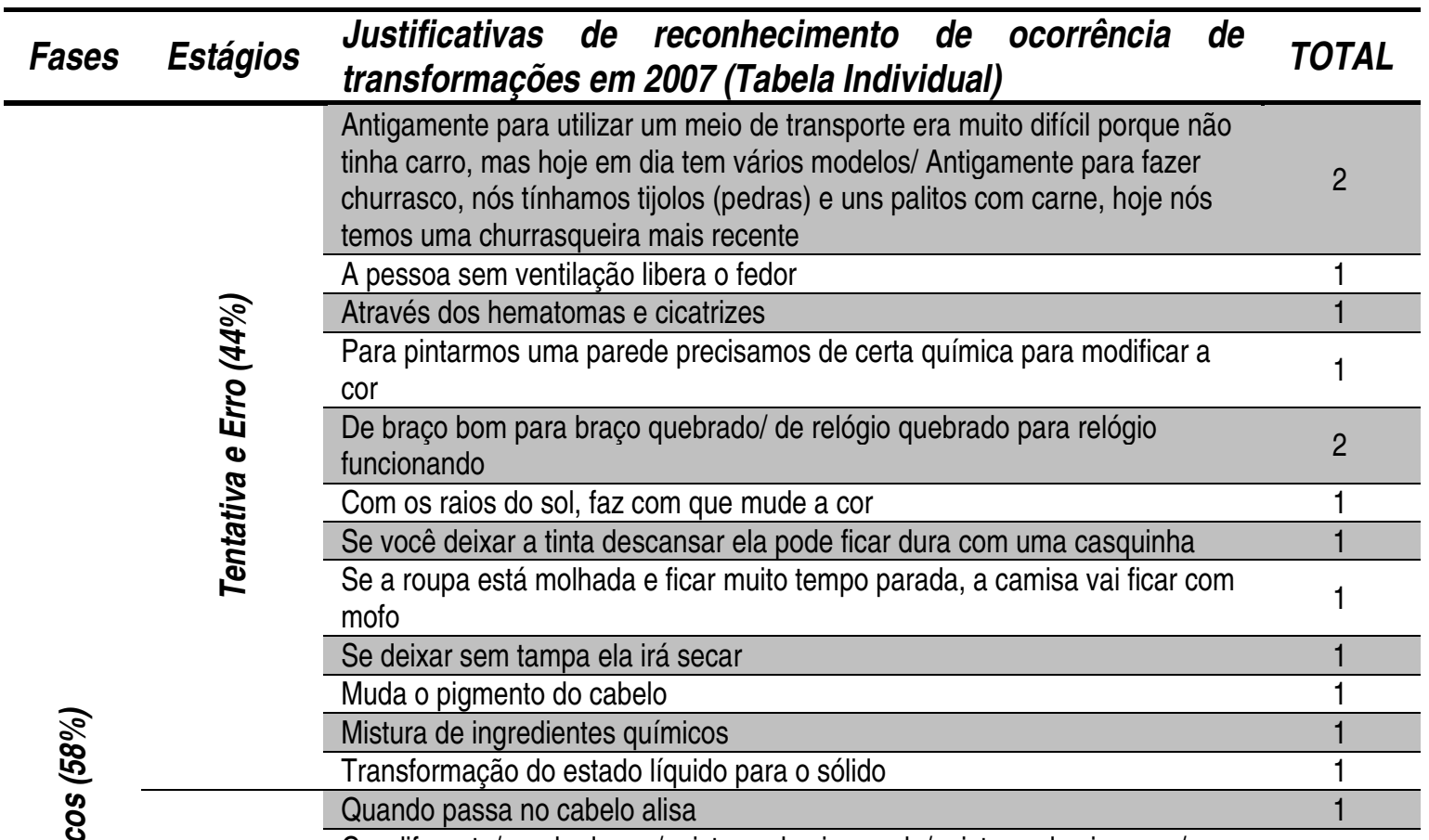

Cor diferente/ muda de cor/ misturando vira verde/ misturando vira roxo/ se juntá-las se transforma em marrom/ vendo a mudança de mistura das cores/ de cabelo colorido para cabelo preto/ com a mistura ele fica cinza/ dar uma cor mais bonita/ de amarelo para marrom/ de unha colorida para unha descolorida

Novo visual/ aparência/ notamos pela coloração/ a pessoa pode mudar de cor

Muda a textura

Aumentou de tamanho, a cor ficou mais forte 1

Coloca no forno pequeno e sai grande/ quando põe no forno cresce e fica sólido/ misturando os ingredientes, usando fermento, o bolo cresce conforme ele assa/

O papel era branco, estava inteiro e depois virou cinzas/ quando queimado vira cinzas

Crescimento dos dentes, cabelos, unhas, pêlos, o corpo em geral/ se transforma ao longo do tempo/ o gato nasce pequeno e depois se desenvolve/ fisionomia diferente

Mudança de cor, forma, tamanho e peso/ muda de cor e fica mole/ amolecer

Depois de alguns dias ela apodrece/ porque a maçã boa é vermelha $e$ durinha, quando ela estraga fica preta e mole

Quando nós o apontamos fica pequeno/ de tanto apontar acaba

1

Há muito tempo atrás ela era preto e branco e hoje ela é colorida/ antes a

TV era sem cor e agora tem

De pele clara para pele escura

TOTAL AMONTOADOS SINCRÉTICOS

Após comermos acontece a digestão/ ao ingerir alimento o que não serve sai/ bebemos líquido e o que não serve sai pela urina

O alimento estava cru, mas após fritá-lo ele fica mais saboroso e dura mais/ coloca para cozinhar duro e sai mole/ quando cozinha ele fica mole/ quando cozido ele se torna comestível/ põe no fogo cru e sai cozida/antes de cozinhá-lo ele está cru/ amolece na água quente/ depois que põe o óleo ele frita/

\section{Quando põe na geladeira endurece}

Com o pó mais água quente (fervente) vira café; com a água quente se transforma

3

2

2

1

157

3


Continuação

\begin{tabular}{llc}
\hline Fases Estágios & $\begin{array}{l}\text { Justificativas de reconhecimento de ocorrência de } \\
\text { transformações em 2007 (Tabela Individual) }\end{array}$ & TOTAL \\
\hline & $\begin{array}{l}\text { Presença de vapor; fervendo antes a água estava numa temperatura } \\
\text { ambiente e logo após ficou quente/ quando está fervendo evapora/ a água } \\
\text { era líquida e ficou sólida }\end{array}$ & 4 \\
\hline $\begin{array}{l}\text { Quando plantada era semente, depois vira uma árvore grande } \\
\text { Ela cresce se reproduz e morre/ ao ela se abrir, se desenvolver, crescer, } \\
\text { reproduzir/ após um tempo a flor se transforma em fruto/ nasce, cresce e } \\
\text { morre/ era semente e depois de um tempo ela se tornou uma planta, árvore }\end{array}$ & 5 \\
\hline $\begin{array}{l}\text { Misturando ovos, farinha, açúcar, sal, fermento e leite, levar ao forno para } \\
\text { aquecer para o fermento agir e assar o pão }\end{array}$ & 1 \\
\hline $\begin{array}{l}\text { O gelo é feito da água, ao ficar duro ele se torna sólido, quando derrete volta } \\
\text { a ser líquido }\end{array}$ & 1 \\
\hline $\begin{array}{l}\text { De líquido ou pó, passa a ser espuma, com a junção de água } \\
\text { Muda a oleosidade da pele e o cheiro muda }\end{array}$ & 1 \\
\hline $\begin{array}{l}\text { Quando tomamos o remédio nossos organismos sofrem uma reação e } \\
\text { quando não é rejeitado melhoramos }\end{array}$ & 1 \\
\hline $\begin{array}{l}\text { Quando põe na cândida muda de cor/ se você pegar uma roupa branca e } \\
\text { colocá-la em uma tinta preta, você vai ver que vai ocorrer uma coloração } \\
\text { que vai mudar o pigmento da roupa/ de parede branca para uma parede } \\
\text { preta }\end{array}$ & 3 \\
\hline
\end{tabular}

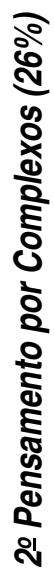

Ao ser queimada sofre uma transformação/ o papel passou de papel para cinzas, mudou de cor, diminuiu o peso e mudou a matéria

De uma árvore para uma porta

Depois de nove meses do óvulo fecundado nasce uma criança

Nós plantamos, regamos, colhemos e depois a consumimos

2

Quando nós nascemos somos um bebê, mas com o passar do tempo

crescemos e ficamos grandes/ quando nós nascemos, nascemos pequenos

e com o passar do tempo, nós crescemos de tamanho, aumentando nosso

peso, etc/ quando somos pequenos nossos ossos são pequenos ao

crescermos nossos ossos ficam maiores, assim ficamos maiores

As plantas absorvem o gás carbônico que combinado com a água, e ambos

são transformados em glicose e oxigênio

Ela estava verde e ao passar de 2 dias ela fica amarela

O fruto está maduro quando não consumido passa por uma reação química

Ele é duro e com o tempo amolece/ Com o passar do tempo ela apodrece/

apodrece se não usar

Nós estamos fedidos e depois ficamos cheirosos/ a pessoa entra suja, mas

sai limpa depois quando usamos o sabonete ele acaba

1

1

Foi cortado, costurado e aí houve a transformação/ era só um tecido e foi confeccionado, até virar roupas

No carro sua transformação é rápida se transformando em fumaça/ entra

líquida e sai como fumaça

Se tornará vinagre o que pode ser perigoso a saúde

1

Amassando a uva e fazendo o vinho

Principalmente nos homens a voz muda/ quando somos pequenos a nossa

fala fica fina e quando ficamos maiores a nossa voz engrossa

Com o passar dos dias o cabelo cresce/ que no mesmo caso do cabelo ao

passar dos dias ela cresce/ Com o passar do tempo ele vai envelhecer

De cabelo comprido para cabelo curto/ de unha grande para unha curta

Está poluído/ agora é muito mais poluído

Os materiais usados mudam de estado e forma/ transformação

O corpo começa a cheirar mal e perder massa

Os metais mudam de estado sólido para líquido/ quando exposto ao fogo ele derrete

1

3

3

1

2

1

1

3

2


Conclusão

\begin{tabular}{|c|c|c|c|}
\hline Fases & Estágios & $\begin{array}{l}\text { Justificativas de reconhecimento de ocorrência de } \\
\text { transformações em } 2007 \text { (Tabela Individual) }\end{array}$ & TOTAL \\
\hline \multirow{7}{*}{ 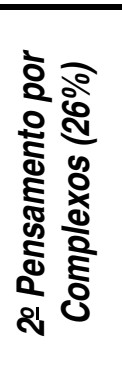 } & \multirow{7}{*}{ 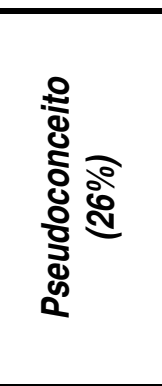 } & $\begin{array}{l}\text { O ouro é encontrado em garimpos, derretido, depois é transformado em } \\
\text { colares, anéis, brincos, pingentes }\end{array}$ & 1 \\
\hline & & Depois de comer estão sujos & 1 \\
\hline & & Bola cheia para bola vazia & 1 \\
\hline & & De folha inteira para folha pela metade & 1 \\
\hline & & É um grão que é colhido, tratado e processado e vira pó & 1 \\
\hline & & $\begin{array}{l}\text { Quando ele é retirado do mar ele vai para salina é tratado e vai para as } \\
\text { pessoas utilizarem }\end{array}$ & 1 \\
\hline & & TOTAL PENSAMENTO POR COMPLEXOS & 71 \\
\hline \multirow{6}{*}{ 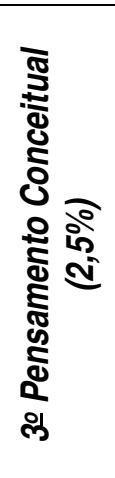 } & \multirow{4}{*}{ 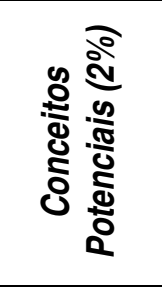 } & $\begin{array}{l}\text { Antes era um pó que se dissolveu na água quente e foi refrigerado, } \\
\text { ficando com uma consistência gelatinosa }\end{array}$ & 1 \\
\hline & & $\begin{array}{l}\text { Que o gás do fogão reage com o oxigênio do ar para produzir o calor que } \\
\text { utilizamos para cozinhar }\end{array}$ & 1 \\
\hline & & Depois de lavar, cortar e temperar, a verdura vira salada & 1 \\
\hline & & $\begin{array}{l}\text { Passa do estado sólido direto para o gasoso/ vapor de água se transforma } \\
\text { em chuva }\end{array}$ & 2 \\
\hline & \multirow{2}{*}{ 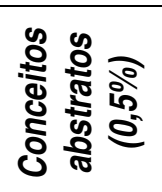 } & $\begin{array}{l}\text { A luz do sol é transformada em energia, por exemplo, a luz do sol passa } \\
\text { por um tipo de material, similar ao vidro, podendo então aquecer a água, } \\
\text { um cômodo, etc. }\end{array}$ & 1 \\
\hline & & TOTAL PENSAMENTO CONCEITUAL & 6 \\
\hline \multirow{25}{*}{\multicolumn{2}{|c|}{ Outros $(13,5 \%)$}} & Muda de cheiro e sabor & 1 \\
\hline & & Lama & 1 \\
\hline & & Cansaço, dor muscular/ respiração ofegante/ perda de peso & 5 \\
\hline & & A árvore tem várias utilidades com ela podemos fazer o papel, fogo, lápis & 1 \\
\hline & & $\begin{array}{l}\text { Desmatar, derrubar, extrair a celulose da madeira e levar para a fábrica } \\
\text { para produzir papel }\end{array}$ & 1 \\
\hline & & $\begin{array}{l}\text { Como, por exemplo, no churrasco, a junção do álcool com uma faísca de } \\
\text { fósforo, logo se acende uma chama de fogo }\end{array}$ & 1 \\
\hline & & Ela fede e tem uma consistência ruim & 1 \\
\hline & & $\begin{array}{l}\text { Mau hálito, ressaca, nervoso, euforia, embriaguês, dor de cabeça/ } \\
\text { pessoas alegres/ muda o sabor e a temperatura }\end{array}$ & 3 \\
\hline & & $\begin{array}{l}\text { Porque tinha duas festas para ir ao mesmo horário/ uma pessoa feliz/ ter } \\
\text { amigos/ conhecer coisas novas/ descansar/ ficar com mais idade/ estar } \\
\text { satisfeito/ cheirar bem }\end{array}$ & 8 \\
\hline & & Que já não tinha mais bicho & 1 \\
\hline & & Inverno, verão, outono e primavera & 1 \\
\hline & & $\begin{array}{l}\text { É uma mistura de vários compostos (o octano, composto formado por } \\
\text { carbono e hidrogênio...) }\end{array}$ & 1 \\
\hline & & Produz o mel & 1 \\
\hline & & Emissão de sons/ é muito importante a pessoa falar & 2 \\
\hline & & Agora tudo é mais fácil & 1 \\
\hline & & As unhas não têm química & 1 \\
\hline & & $\begin{array}{l}\text { Para termos a casa limpa é preciso muitos produtos que contém química, } \\
\text { o que limpa, o que dá cheira e muitos outros }\end{array}$ & 1 \\
\hline & & Pessoa antes era viva & 1 \\
\hline & & Perda momentânea da consciência, perturbações, alucinações & 1 \\
\hline & & $\begin{array}{l}\text { Jogando esgoto na água tem micróbios e é um veículo de doenças; em } \\
\text { vez de cristalina ela é preta/ um rio limpo e um rio sujo }\end{array}$ & 2 \\
\hline & & Progredir & 1 \\
\hline & & Casas, prédios, etc. & 1 \\
\hline & & TOTAL OUTROS & 37 \\
\hline & & TOTAL DE CITAÇÕES & 275 \\
\hline & & TOTAL DE ALUNOS PARTICIPANTES & 83 \\
\hline
\end{tabular}




\begin{tabular}{|c|c|c|c|}
\hline Fases & Estágios & $\begin{array}{l}\text { Justificativas de reconhecimento de ocorrência de } \\
\text { transformações em } 2007 \text { (Tabela Coletiva) }\end{array}$ & $(\%)$ \\
\hline \multirow{12}{*}{ 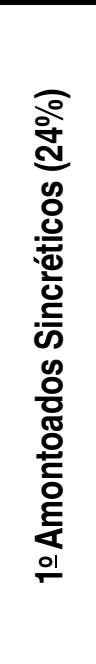 } & \multirow{7}{*}{$\begin{array}{l}\text { Tentativa e Erro } \\
(\mathbf{8} \%)\end{array}$} & $\begin{array}{l}\text { O ovo foi chocado por outra galinha, se quebrou e deu origem a outra } \\
\text { galinha }\end{array}$ & 1 \\
\hline & & Sentir o sabor do pão que antes estava inteiro e depois ele foi digerido & 1 \\
\hline & & Amolecer & 1 \\
\hline & & O ovo estava líquido, adquiriu consistência, sabor, cor, cheiro & 1 \\
\hline & & $\begin{array}{l}\text { Ocorre a copulação entre o homem e a mulher, daí o espermatozóide } \\
\text { fecunda o óvulo }\end{array}$ & 1 \\
\hline & & $\begin{array}{l}\text { Desmatar, derrubar a árvore e extrair a celulose da madeira e levar para a } \\
\text { fábrica para produzir o papel }\end{array}$ & 1 \\
\hline & & $\begin{array}{l}\text { O papel estava usado, rasgado, daí ele passa por uma produção que é o } \\
\text { processo de reciclagem e se transforma em um papel novo. }\end{array}$ & 1 \\
\hline & \multirow{4}{*}{$\begin{array}{c}\text { Organização do } \\
\text { Campo Visual } \\
(16 \%)\end{array}$} & Mudou a cor da pele; a pele clara ficou escura & 1 \\
\hline & & Mudou a cor do cabelo & 1 \\
\hline & & Era de uma cor e ficou de outra, muda o pigmento do cabelo & 1 \\
\hline & & Mudar a cor e ficar mole & 1 \\
\hline & & TOTAL AMONTOADOS SINCRÉTICOS & 11 \\
\hline \multirow{16}{*}{ 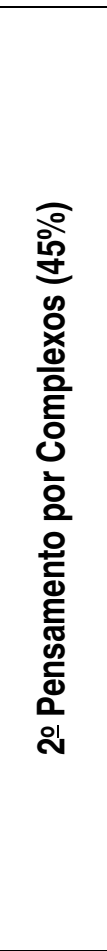 } & \multirow{15}{*}{$\begin{array}{l}\text { Pseudoconceito } \\
(45 \%)\end{array}$} & Presença de vapor & 1 \\
\hline & & $\begin{array}{l}\text { Fervendo, antes a água estava numa temperatura ambiente e logo após } \\
\text { ficou quente }\end{array}$ & 1 \\
\hline & & A água era líquida e ficou sólida & 1 \\
\hline & & $\begin{array}{l}\text { Misturando ovos, farinha, açúcar, sal, fermento e leite, levar ao forno para } \\
\text { aquecer, para o fermento agir e assar o pão }\end{array}$ & 1 \\
\hline & & $\begin{array}{l}\text { Era uma massa macia, pequena que foi aquecida, cresceu e ficou crocante } \\
\text { com casca }\end{array}$ & 1 \\
\hline & & O papel era branco, estava inteiro e depois virou cinzas & 1 \\
\hline & & $\begin{array}{l}\text { Quando tomamos o remédio nosso organismo sofre uma reação e quando } \\
\text { não rejeitado melhoramos }\end{array}$ & 1 \\
\hline & & Era uma semente e depois de um tempo se tornou uma planta, uma árvore & 1 \\
\hline & & O ser vivo estava parado e se movimentou se locomoveu & 1 \\
\hline & & Crescimento dos dentes, cabelos, unhas, pêlos, ossos, o corpo em geral & 1 \\
\hline & & Nascem, crescem, a maioria se reproduz, envelhecem e morrem & 1 \\
\hline & & Forma o casulo, a lagarta passa por uma mudança e sai a borboleta & 1 \\
\hline & & $\begin{array}{l}\text { Estava cru, duro, mudou o gosto, ele cresce, muda a textura e a } \\
\text { consistência }\end{array}$ & 1 \\
\hline & & $\begin{array}{l}\text { Antes era um pó que se dissolveu na água quente e foi refrigerado, criando } \\
\text { uma consistência gelatinosa }\end{array}$ & 1 \\
\hline & & $\begin{array}{l}\text { Antes ele era um caroço, era duro, amarelo e ficou branco, grande, macio, } \\
\text { crocante }\end{array}$ & 1 \\
\hline & & TOTAL PENSAMENTO POR COMPLEXOS & 15 \\
\hline \multirow{6}{*}{\multicolumn{2}{|c|}{ Outros (10\%) }} & $\begin{array}{l}\text { Mau hálito, ressaca, nervoso, euforia, embriaguês, dor de cabeça, } \\
\text { etc. }\end{array}$ & 1 \\
\hline & & Transpiração, cansaço, dor muscular & 1 \\
\hline & & $\begin{array}{l}\text { A Tiffany foi ao cabeleireiro e cortou o cabelo que era longo, grande e } \\
\text { ficou careca }\end{array}$ & 1 \\
\hline & & Perda momentânea da consciência, perturbações, alucinações & 1 \\
\hline & & $\begin{array}{l}\text { A pessoa estava fisicamente inteira,s em lesões e depois o corpo se } \\
\text { movimentou, ficou roxo (hematomas) e dolorido }\end{array}$ & 1 \\
\hline & & TOTAL OUTROS & 5 \\
\hline \multicolumn{3}{|r|}{ TOTAL DE CITAÇÕES } & 49 \\
\hline \multicolumn{3}{|r|}{ TOTAL DE ALUNOS PARTICIPANTES } & 47 \\
\hline
\end{tabular}


ANEXO D3 - Tabela organizada para observação das etapas de formação do conceito de transformação em alunos do ano letivo de 2006, conforme a terceira atividade analisada.

\begin{tabular}{|c|c|c|c|}
\hline Fases & Estágios & Respostas para ocorrência de reação química (2006) & $(\%)$ \\
\hline \multirow{6}{*}{ 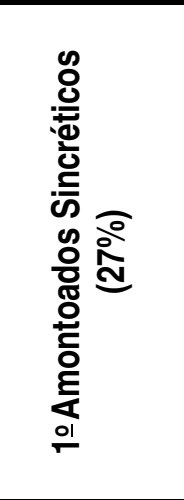 } & \multirow{4}{*}{$\begin{array}{l}\text { Tentativa e Erro } \\
\qquad(9 \%)\end{array}$} & Mudou o cheiro e etc & 1 \\
\hline & & $\begin{array}{l}\text { Com o aquecimento do material ele libera um gás incolor e logo depois } \\
\text { há a formação de um líquido prateado, ou seja, a substância que dá } \\
\text { coloração ao material se desprende devido ao aquecimento e se torna } \\
\text { um gás incolor }\end{array}$ & 1 \\
\hline & & $\begin{array}{l}\text { Alterou a estrutura da matéria. Era um sólido vermelho e virou um líquido } \\
\text { prateado }\end{array}$ & 1 \\
\hline & & Porque de gás incolor ele virou um líquido prateado & 3 \\
\hline & $\begin{array}{l}\text { Organização do } \\
\text { Campo Visual } \\
(18 \%)\end{array}$ & A cor mudou/ pela mudança de cor & 8 \\
\hline & & TOTAL AMONTOADOS SINCRÉTICOS & 12 \\
\hline \multirow{13}{*}{ 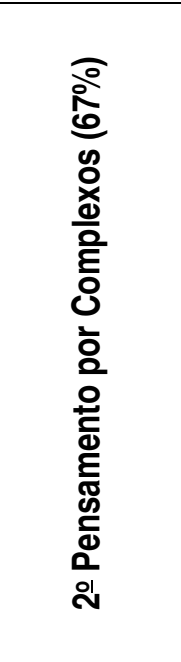 } & \multirow{12}{*}{$\begin{array}{l}\text { Pseudoconceito } \\
\qquad(67 \%)\end{array}$} & Liberou gás & 9 \\
\hline & & A cor mudou e formou um líquido prateado & 4 \\
\hline & & Apareceram novos materiais & 1 \\
\hline & & O sistema transformou e mudou a cor & 1 \\
\hline & & Houve uma nova substância (sólido para líquido) & 1 \\
\hline & & Ele passou de sólido para líquido & 3 \\
\hline & & Ocorreu a mudança de cor, de estado, & 1 \\
\hline & & A substância se transformou em líquido e em gás & 1 \\
\hline & & $\begin{array}{l}\text { Ocorreu pela formação/transformação de uma nova substância (líquido } \\
\text { prateado) }\end{array}$ & 7 \\
\hline & & $\begin{array}{l}\text { Ele virou do sólido para o líquido e do vermelho para o prateado e uma } \\
\text { liberação de gás }\end{array}$ & 1 \\
\hline & & $\begin{array}{l}\text { A liberação de um gás incolor e a transformação de um sólido vermelho } \\
\text { para um líquido prateado }\end{array}$ & 1 \\
\hline & & Liberou um gás incolor & 1 \\
\hline & & TOTAL PENSAMENTO POR COMPLEXOS & 31 \\
\hline \multirow{3}{*}{ 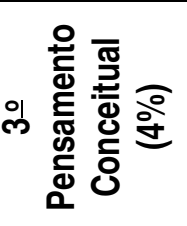 } & $\begin{array}{c}\text { Conceitos } \\
\text { Potenciais (2\%) }\end{array}$ & $\begin{array}{l}\text { Porque de um sólido vermelho houve a formação de um líquido prateado } \\
\text { e durante esse processo ele liberou um gás incolor }\end{array}$ & 1 \\
\hline & $\begin{array}{c}\text { Conceitos } \\
\text { Abstratos (2\%) } \\
\end{array}$ & $\begin{array}{l}\text { Era um sólido vermelho que depois de aquecido liberou um gás incolor e } \\
\text { formou-se um líquido prateado }\end{array}$ & 1 \\
\hline & & TOTAL PENSAMENTO CONCEITUAL & 2 \\
\hline \multicolumn{2}{|c|}{ Outros $(2 \%)$} & $\begin{array}{l}\text { Por exemplo, quando você mistura as soluções de hidróxido de sódio e } \\
\text { ácido clorídrico não houve evidência }\end{array}$ & 1 \\
\hline & & TOTAL DE CITAÇÕES & 46 \\
\hline \multicolumn{3}{|r|}{ TOTAL DE ALUNOS PARTICIPANTES } & 47 \\
\hline
\end{tabular}


ANEXO D4 - Tabela organizada para observação das etapas de formação do conceito de transformação em alunos do ano letivo de 2007, conforme a terceira atividade analisada.

\begin{tabular}{|c|c|c|c|}
\hline Fases & Estágios & Respostas para ocorrência de reação química (2007) & $(\%)$ \\
\hline \multirow{11}{*}{ 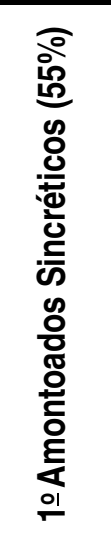 } & \multirow{6}{*}{$\begin{array}{c}\text { Tentativa e Erro } \\
(30 \%)\end{array}$} & Houve mudança material & 1 \\
\hline & & Mudança de cheiro & 1 \\
\hline & & Se transformou em um novo material & 1 \\
\hline & & Ocorreu alteração da matéria & 1 \\
\hline & & $\begin{array}{l}\text { O aquecimento liberou um gás incolor e a formação de um líquido } \\
\text { prateado }\end{array}$ & 1 \\
\hline & & Modificou sua estrutura & 1 \\
\hline & \multirow{4}{*}{$\begin{array}{c}\text { Organização do } \\
\text { Campo Visual } \\
(25 \%)\end{array}$} & Mudança de cor & 1 \\
\hline & & De um sólido vermelho virou um líquido prateado e gasoso & 1 \\
\hline & & Liberação de gás incolor e formação de um líquido prateado & 1 \\
\hline & & $\begin{array}{l}\text { De sólido ficou líquido/ Antes ele era sólido e depois do ocorrido ficou } \\
\text { líquido }\end{array}$ & 2 \\
\hline & & TOTAL AMONTOADOS SINCRÉTICOS & 11 \\
\hline \multirow{10}{*}{ 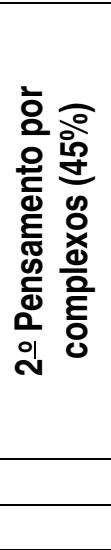 } & \multirow{7}{*}{$\begin{array}{c}\text { Pensamento } \\
\text { por Complexos } \\
(45 \%)\end{array}$} & Mudou a cor e liberou um gás & 1 \\
\hline & & Era um sólido vermelho e se transformou em um líquido prateado & 1 \\
\hline & & $\begin{array}{l}\text { Mudou o estado de sólido para líquido e altera a cor/ Mudou de estado } \\
\text { sólido para líquido e a cor de vermelho para prateado }\end{array}$ & 2 \\
\hline & & Antes ele era um sólido e depois ele virou gás incolor e ficou prateado & 1 \\
\hline & & $\begin{array}{l}\text { Teve liberação de gás, mudança de estado e cor/ Liberação de gases, } \\
\text { mudança de cor e mudança de estado físico }\end{array}$ & 2 \\
\hline & & Quando após o aquecimento do reagente liberou gás, ficou líquida & 1 \\
\hline & & $\begin{array}{l}\text { Passou do sólido para o líquido, liberou gases e mudou de cor vermelho } \\
\text { passou a ser prateado }\end{array}$ & 1 \\
\hline & & TOTAL PENSAMENTO POR COMPLEXOS & 09 \\
\hline & & TOTAL DE CITAÇÕES & 20 \\
\hline & & TAL DE ALUNOS PARTICIPANTES & 64 \\
\hline
\end{tabular}


ANEXO D5 - Tabela organizada para observação das etapas de formação do conceito de transformação em alunos do ano letivo de 2006, conforme a quarta atividade analisada.

\section{Fases $\quad$ Estágios $\quad$ Respostas para ocorrência de reação química (2006)}

\begin{tabular}{|c|c|c|c|}
\hline & & Não. Porque a água só vai soltar bolhas de ar & $\frac{2}{2}$ \\
\hline & & Não. Está aquecendo não está com nenhum outro químico & 2 \\
\hline & & Sim. Porque a água vai liberando um vapor & 1 \\
\hline ì & & $\begin{array}{l}\text { Sim. Porque passou do estado líquido para o sólido que está e virando uma } \\
\text { fumaça }\end{array}$ & 1 \\
\hline \& & & Sim. Porque mudou o estado da matéria & 1 \\
\hline 要 & & Sim. Porque a água evapora & 1 \\
\hline పั & Tentativa e Erro & Sim. Mudou o estado da matéria, do líquido para o gasoso & 1 \\
\hline क & $(46 \%)$ & Sim. Ocorre uma mudança de estado líquido para gasoso & 1 \\
\hline 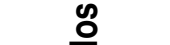 & & Não. Ocorre só a mudança de estado físico & 2 \\
\hline$\overline{\mathbf{T}}$ & & Não. Ele não muda de forma só evapora & 2 \\
\hline 욛 & & Não. Porque ele não altera a substância, ou seja, não deixa de ser água & 2 \\
\hline$\underset{\substack{0 \\
\text { ol }}}{\stackrel{0}{1}}$ & & $\begin{array}{l}\text { Não. Ocorre uma liberação de gás, mas não é uma reação química, pois } \\
\text { não alterou a estrutura da matéria só mudou de estado físico de líquido para } \\
\text { gasoso }\end{array}$ & 1 \\
\hline & & Não. Não houve mudança no elemento $\mathrm{H}_{2} \mathrm{O}$, e sim no estado físico da água & 6 \\
\hline & & Sim. Que a água se aquece e sai uma liberação de gás & 1 \\
\hline & & TOTAL AMONTOADOS SINCRÉTICOS & 26 \\
\hline & & Não. Porque não deixa de ser água apenas vira vapor & 2 \\
\hline & & Não. Porque não deixou de ser água & 2 \\
\hline & & $\begin{array}{l}\text { Não. Ao aquecer a água ela passa de líquido para gasoso, ou seja, o gás } \\
\text { liberado é a própria áqua }\end{array}$ & 2 \\
\hline & & Não. A água só evapora, ela não deixa de ser água & 2 \\
\hline 흥요 & $\begin{array}{l}\text { Pseudoconceito } \\
(49 \%)\end{array}$ & $\begin{array}{l}\text { Não. Porque a água não deixou de ser água só mudou o estado para o } \\
\text { gasoso }\end{array}$ & 2 \\
\hline & & Não. A água só está evaporando & 6 \\
\hline & & Não. Porque a água só evapora & 2 \\
\hline \&్ & & Não. Porque o gás que saiu é apenas um vapor e continua sendo água & 2 \\
\hline ఏ & & Não. O gás é a água em estado gasoso & 6 \\
\hline ৯े & & Não. Esse gás é a água em forma de vapor & 2 \\
\hline & & TOTAL PENSAMENTO POR COMPLEXOS & 28 \\
\hline 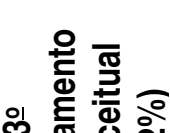 & Conceitos & $\begin{array}{l}\text { Não. Apesar de parte da água ter mudado de estado físico, a água } \\
\text { permanece sendo água em forma de vapor, ou seja, não houve mudança de } \\
\text { sistema. }\end{array}$ & 1 \\
\hline ¿̊ ర & rote & TOTAL PENSAMENTO CONCEITUAL & 1 \\
\hline & $\operatorname{tancos}$ & Não. Não ocorre uma reação química & 2 \\
\hline & ) & TOTAL OUTROS & 2 \\
\hline & & TOTAL DE CITAÇÕES & 57 \\
\hline & & TOTAL DE ALUNOS PARTICIPANTES & 50 \\
\hline
\end{tabular}


ANEXO D6 - Tabela organizada para observação das etapas de formação do conceito de transformação em alunos do ano letivo de 2007, conforme a quarta atividade analisada.

Fases Estágios Respostas para ocorrência de reação química (2007)

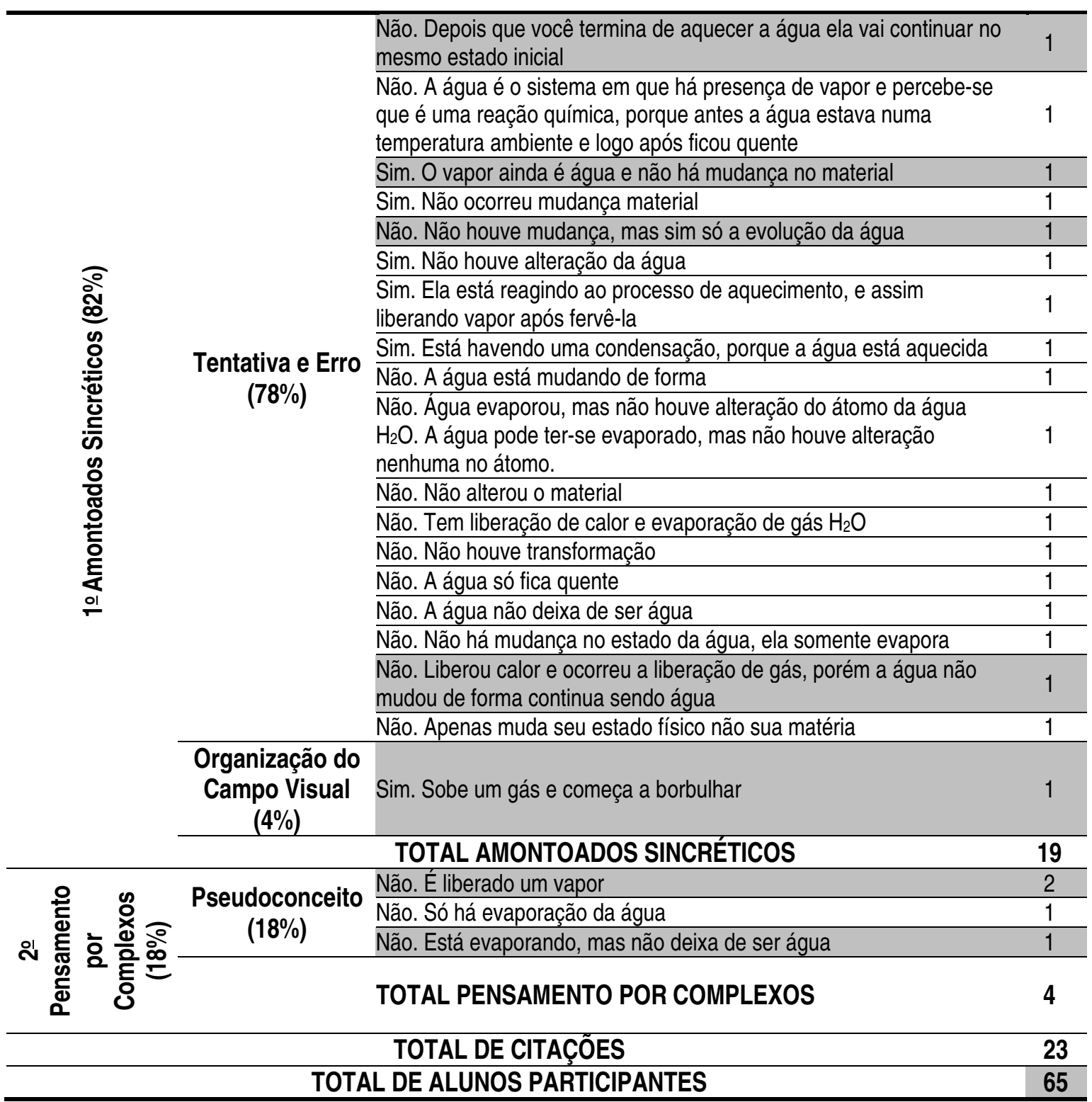


ANEXO E - Tabelas individuais dos alunos dos anos de 2006 e 2007 utilizadas como exemplo para análise da ressignificação do conceito de transformação.

ANEXO E1 - Tabela individual focando as evocações referentes a refrigerante e cerveja

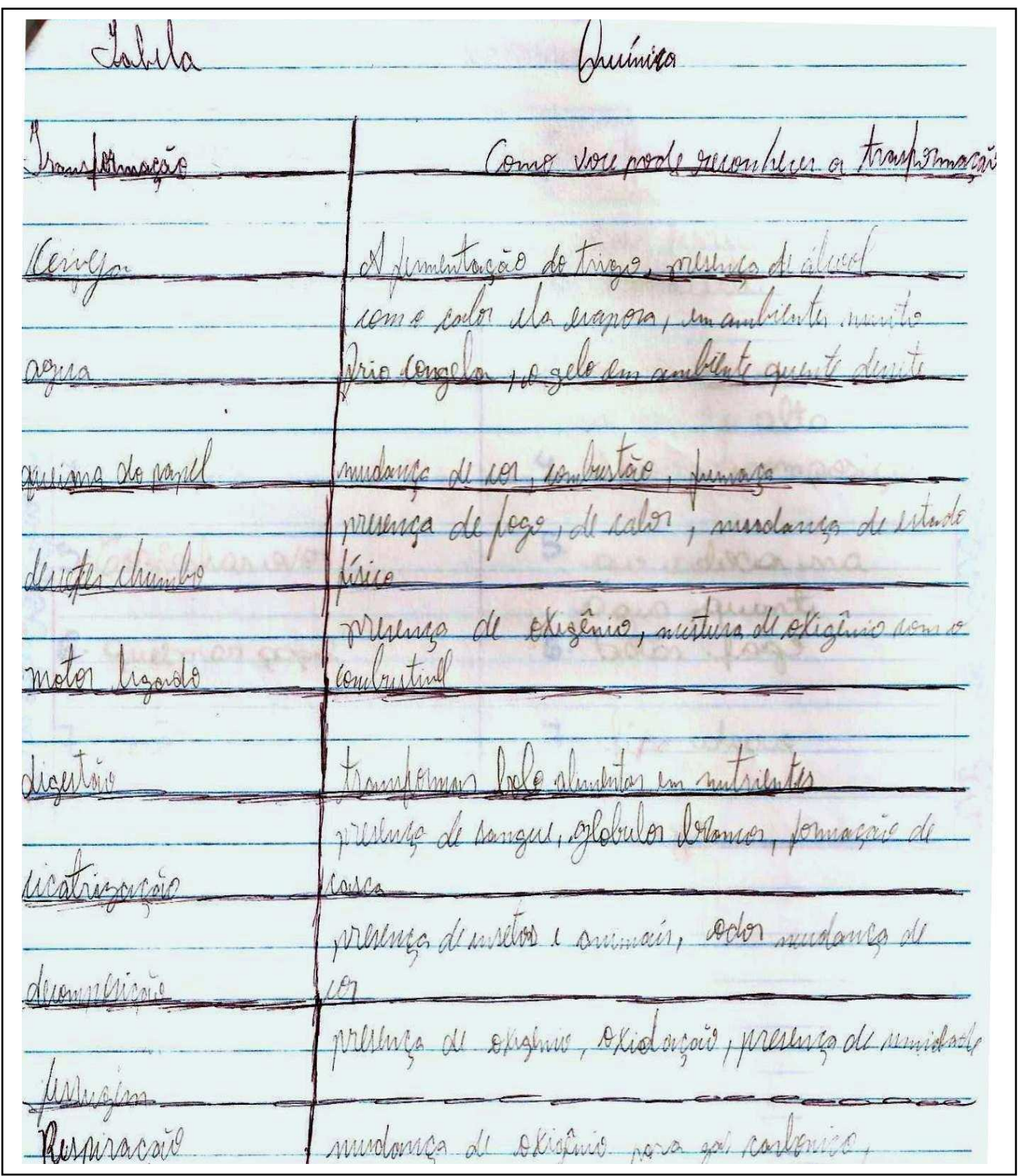


Tabela I-1

Quimica

Transformacía I como vocé pate reconhecer a trairs-

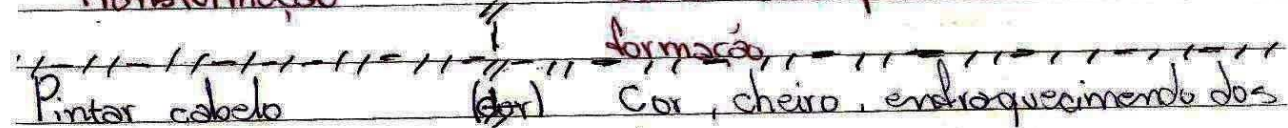

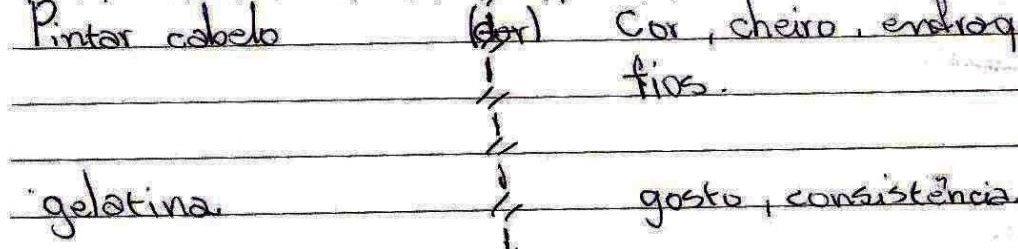

Digestä

lata enterujando<smiles>[C]1[C-]=CC=C1</smiles>

Quebra de moléculast

Pío

Apontarc lápis ///

queima de papel Quando queimado comeca o aparecimen-

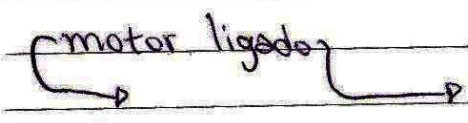
to de cianzas.

Com o aparecimentos pequenos da ferugem

Crescimento, fermentapáa

Olápis fica mar

retrigerante

$1 / 1$

Bolo

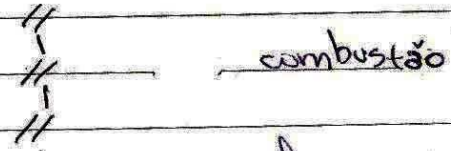

if cor, fermentagá, sabor e gases

if fermontasăo, cor, cheiro,gosto 


\begin{tabular}{|c|c|}
\hline Transformacas & Como foi recontrecids \\
\hline decomposiças & $\begin{array}{l}\text { desmancho, cheiro, pedogos } \\
\text { animais em volto. }\end{array}$ \\
\hline$\sigma_{n}$ & - \\
\hline pas & $\begin{array}{l}\text { fermento, escurece, undurece, } \\
\text { cusce }\end{array}$ \\
\hline$m$ & 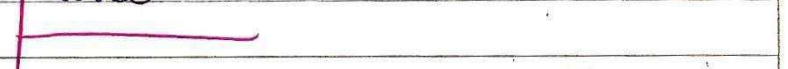 \\
\hline digestass & $\begin{array}{l}\text { suco gástruco, diluiças dos } \\
\text { alimintos }\end{array}$ \\
\hline$n$ & $\longrightarrow n$ \\
\hline 4- corte ma pele & Sicatriz, madorros de por,. \\
\hline $\begin{array}{l}\text { 5- fumare de } \\
\text { onibus }\end{array}$ & liberacps de gás, cheiro, cor \\
\hline$-n$ & - \\
\hline $\begin{array}{l}\text { 6- cfruto prescendo no } \\
\text { árvore }\end{array}$ & lam̃anho, cor, gosto \\
\hline$m-1$ & - \\
\hline $\begin{array}{l}\text { 7-queima de } \\
\text { pnew }\end{array}$ & $\begin{array}{l}\text { cheiro, cov, fumaco, consistêncio } \\
\text { derrete }\end{array}$ \\
\hline int & 5 \\
\hline 8-refrigerante & misturo de gás com léquido, \\
\hline $\begin{array}{l}\text { 9-reloxamento } \\
\text { no cobelo }\end{array}$ & $\begin{array}{l}\text { aliso, tescturo, cheiro, loma- } \\
\text { tho }\end{array}$ \\
\hline
\end{tabular}


ANEXO E2 - Tabela individual focando a evocação referente a unhas.

\begin{tabular}{|c|c|}
\hline Shansiamones & 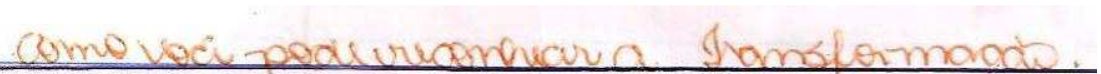 \\
\hline 1D fimente & Ahauriz do cuscimente do paí. \\
\hline $2 \rightarrow \log \theta$ & muidomar de valimentos. \\
\hline $3 \rightarrow$ madira & Inansformoda um misas, caduiras, palitos \\
\hline 4- Barro & Atraviźz de Ligelas vasos, itc \\
\hline 5-1) Ágiva & Atraviźz da ullaporacä, fuvinaia. \\
\hline 6- Deluera & mistura de ulimintos \\
\hline$\exists \rightarrow$ vula & Atravizz de derutiminte. \\
\hline 8-12 Rimidio & mistura de váiar substâmaias \\
\hline it Nhe & Sazer sabrä bavar houra \\
\hline $10 \rightarrow$ Unhas & Ahave'z de cuscimento. \\
\hline
\end{tabular}


ANEXO E3 - Tabelas individuais focando as evocações referentes a milho de pipoca.

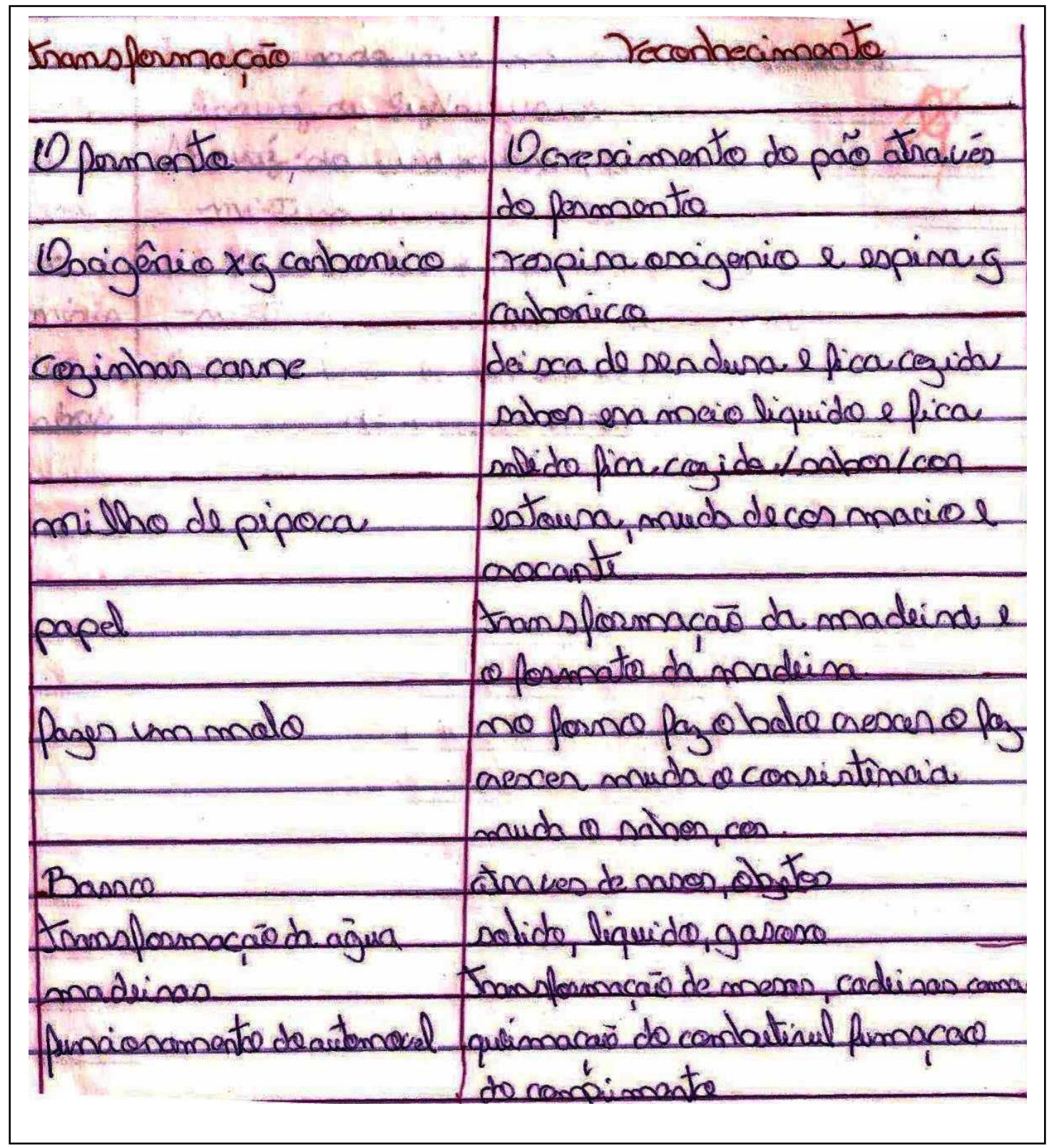


Anexos

231

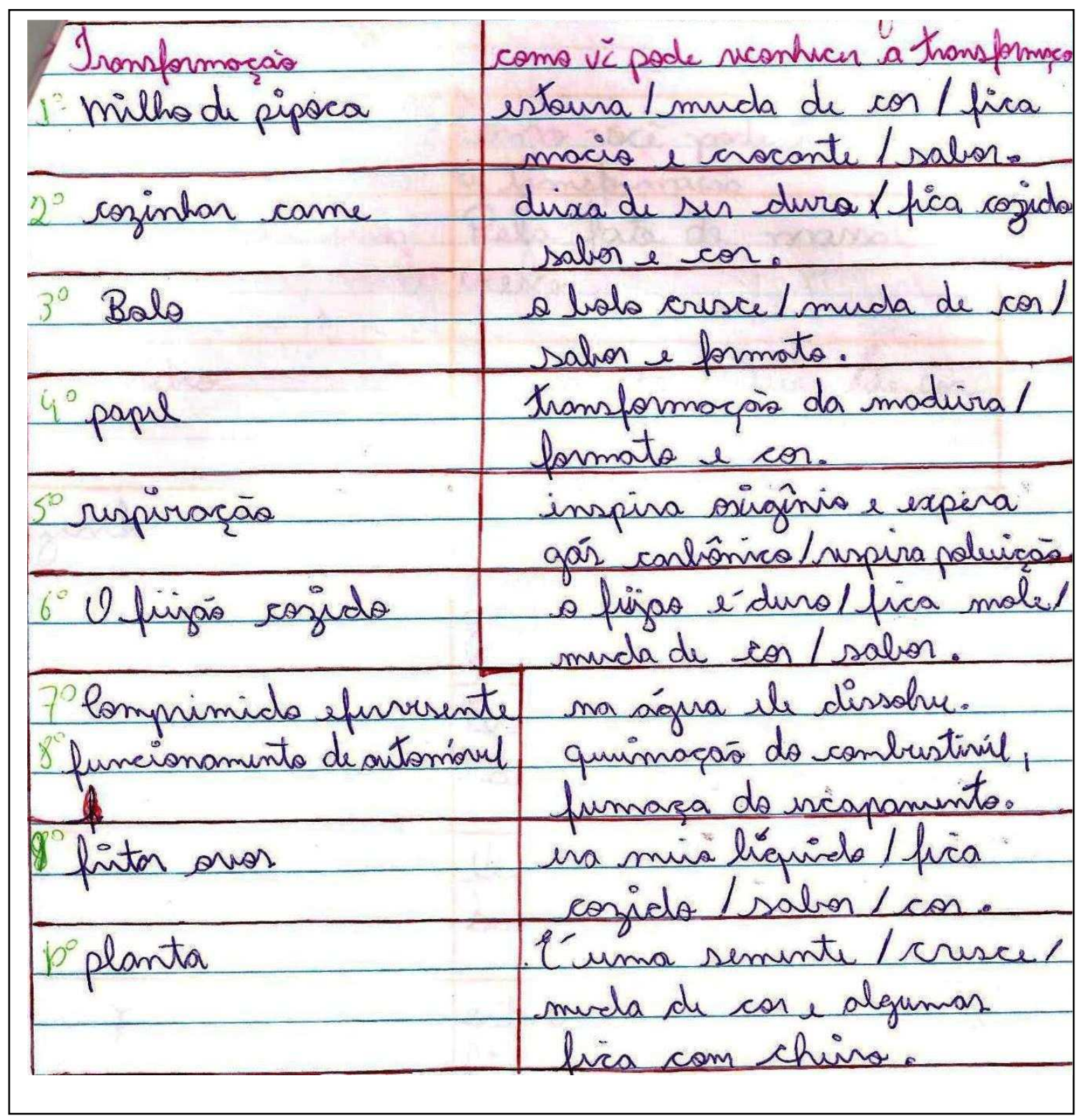


Anexos

232

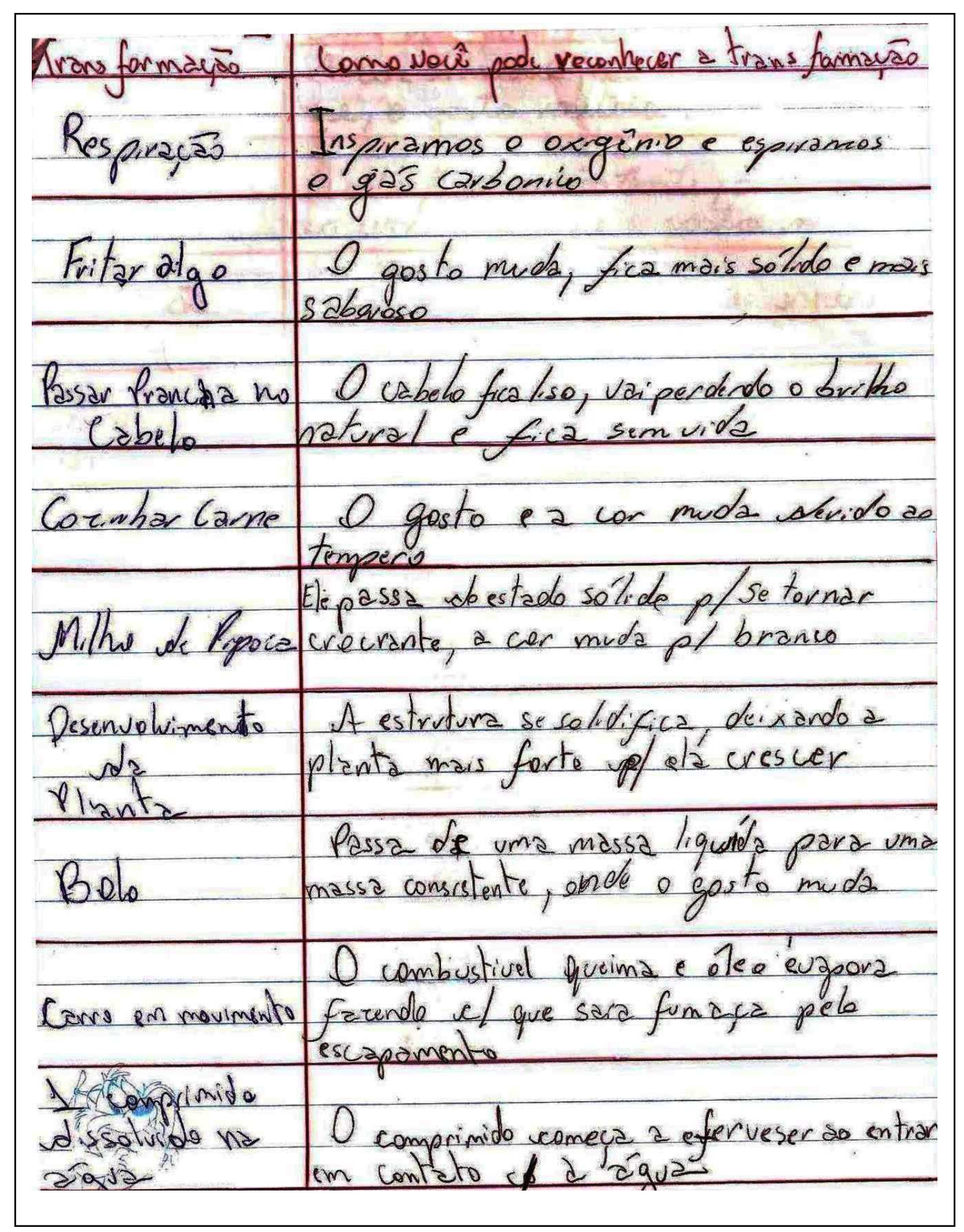


ANEXO E4 - Tabelas individuais focando as evocações referentes a gelatina.

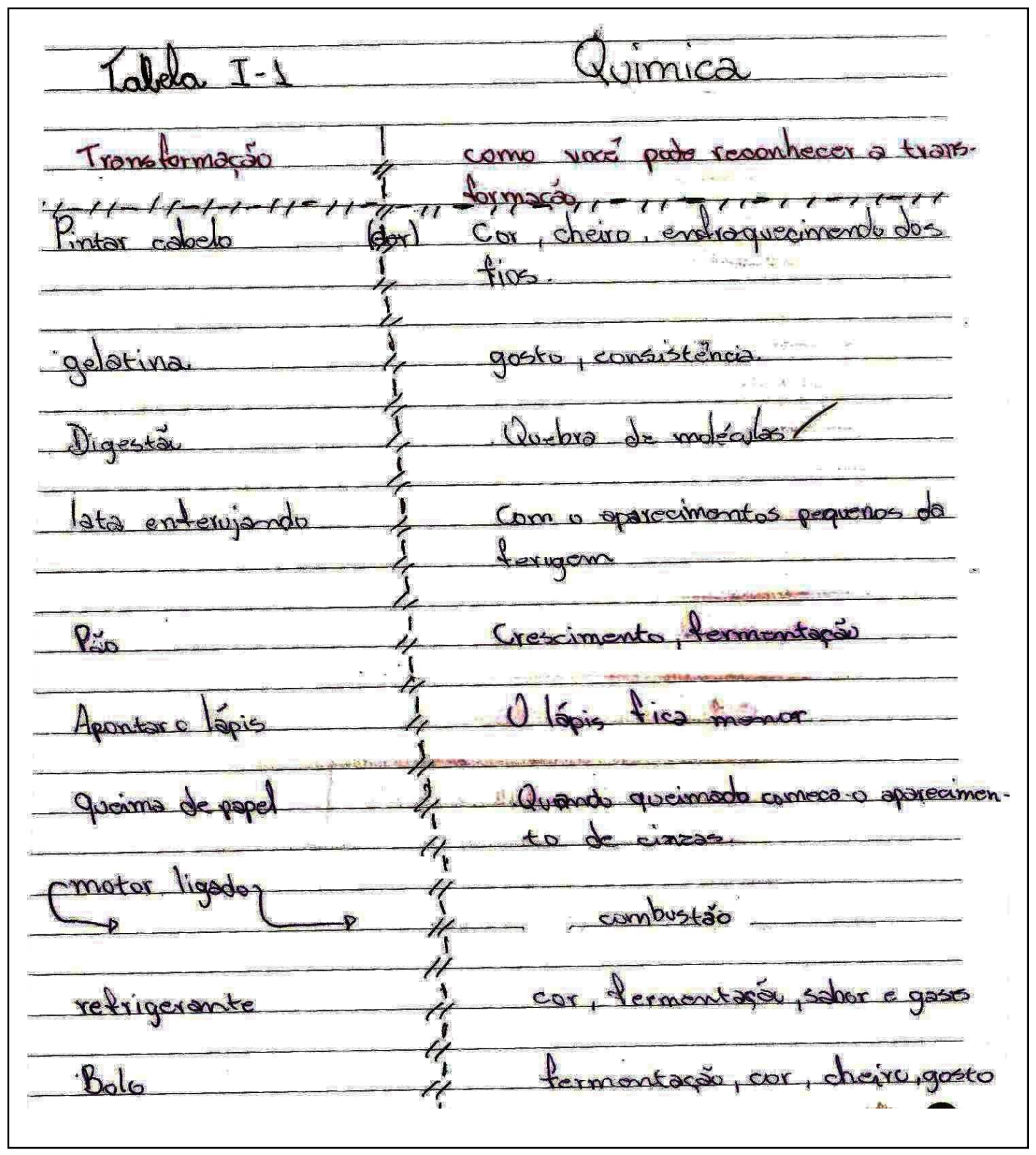




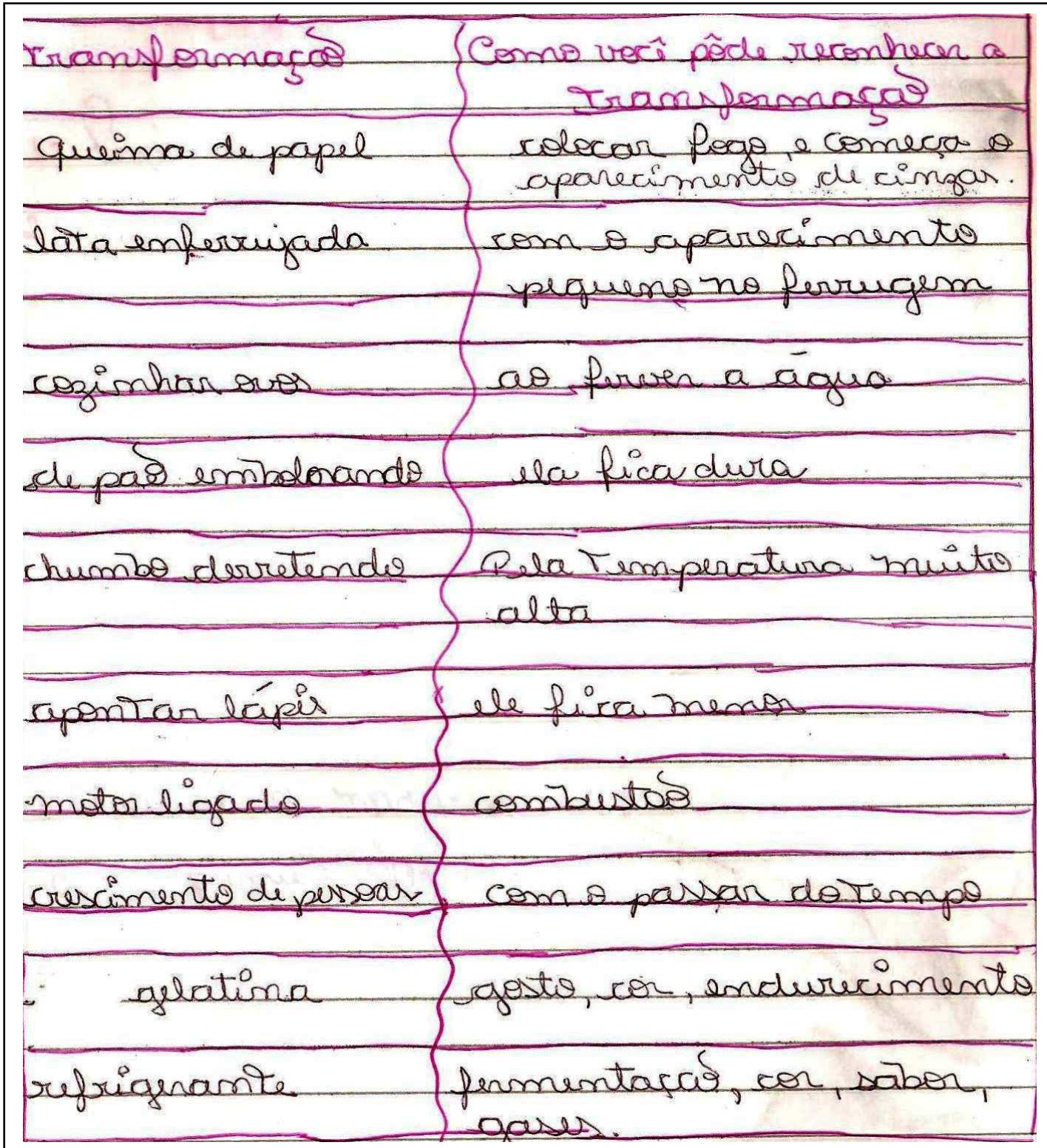


ANEXO E5 - Tabelas individuais focando as evocações referentes a ar.

\begin{tabular}{|c|c|}
\hline Tromafor & 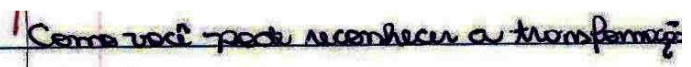 \\
\hline + Tempo nivelodo & O cér carregedo \\
\hline Os dentes & depois de comer estä sujor \\
\hline As meios de comunicocas & Agar tude t mais pacil \\
\hline An $\ldots$ & Agora é müte mais poluids. \\
\hline Crionca & De crianca para homem \\
\hline botas & Depois vira uma rova \\
\hline Cabelo & A pessoe peote, muder de cor \\
\hline lópis & de tanto apontor acdsa \\
\hline mieho & sepois de fito vira pipeca \\
\hline Desentio & Apersea pode colmir. \\
\hline
\end{tabular}

\begin{tabular}{|c|c|}
\hline Jransformacăor & Comer voce pode reconhecur as tramslermacrä? \\
\hline Jintura de cabelo. & Depoir de timaridor, or sabelos ficam com uma no vov cor \\
\hline Boter & Quando olocader ne formo ele ansou e ficu rolido. \\
\hline Áowave swo em pó & Quando misturados a água se tramsiennev uns suco. \\
\hline milho de painocos & 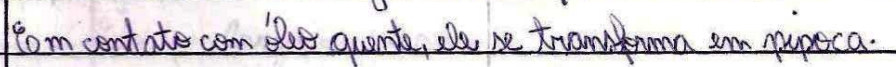 \\
\hline Gräss de Luinar & Quando cozido, ele se torman comestível. \\
\hline Botao de rosa & ado momento, ele se tramsterma em rosea. \\
\hline Giz & - gair, ele se descenta e vira pó. \\
\hline Ar & Eostá poluído. \\
\hline Crexcimento da planta & $\begin{array}{l}\text { Eora semente e depoir de un tempo la se tomou una } \\
\text { planta / áruore. }\end{array}$ \\
\hline 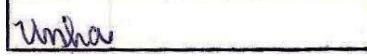 & \\
\hline
\end{tabular}


Anexos

236

ANEXO E6 - Tabela individual focando as evocações referentes a fezes e urina.

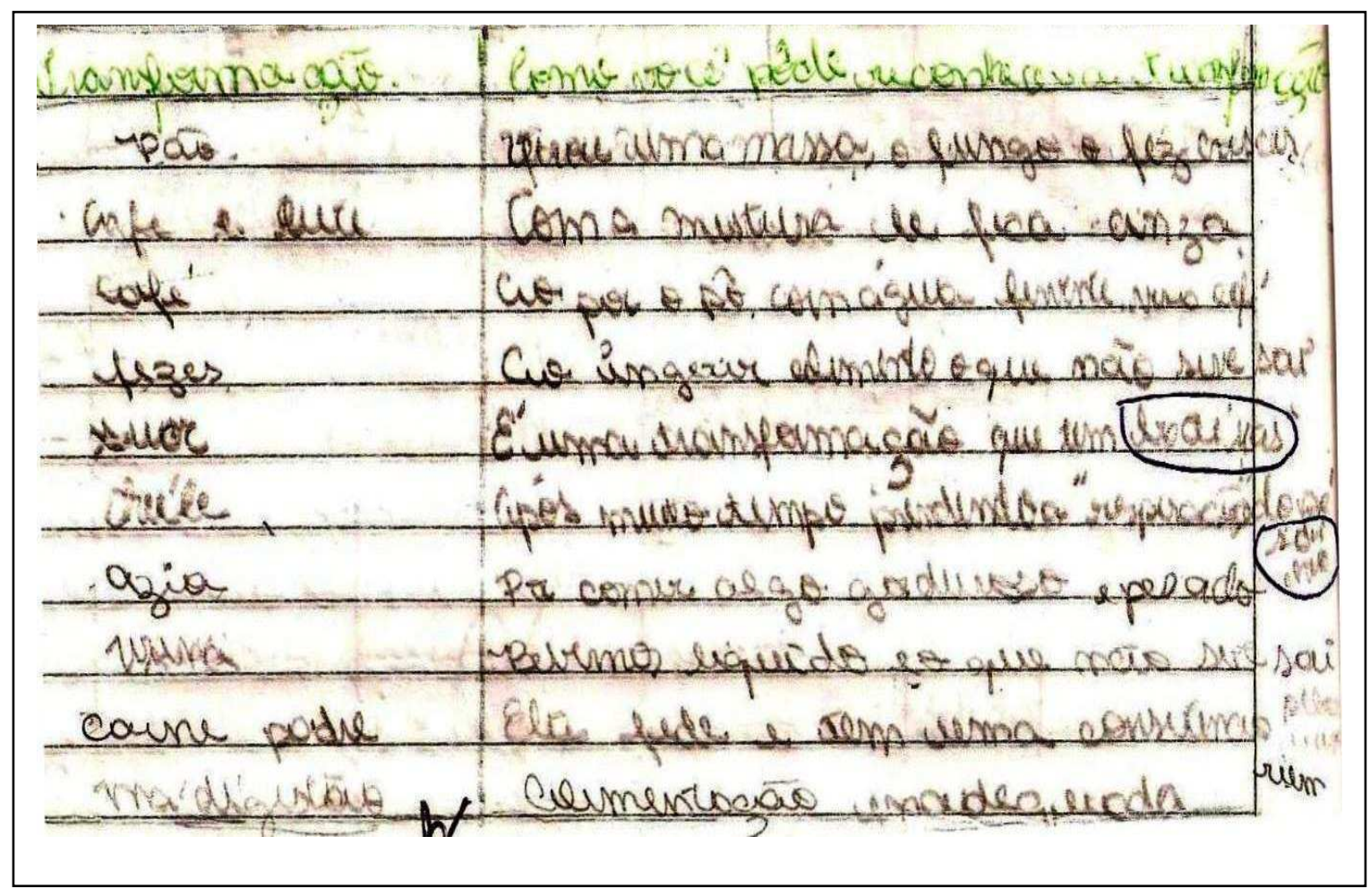


ANEXO E7 - Tabelas individuais focando as evocações referentes a leite e queijo.

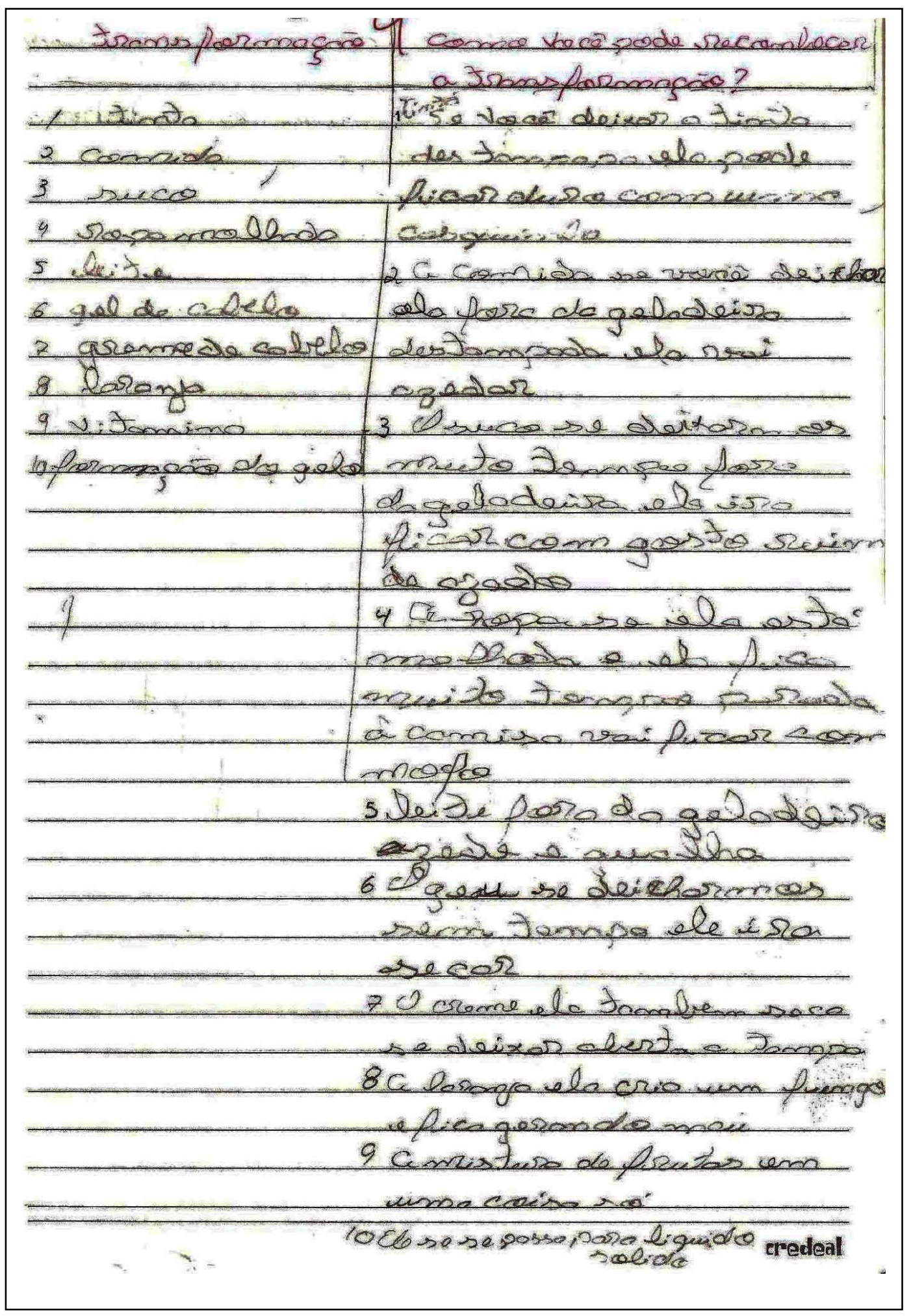




\begin{tabular}{|c|c|}
\hline trampurmacǎo & $\begin{array}{c}\text { Como tocí pode reconbian } \\
\text { a tromolormocoê? }\end{array}$ \\
\hline 19: O fájac & $\begin{array}{l}\text { 10: Quando cozida ele } \\
\text { fuca male aure uma } \\
\text { trans armacar. }\end{array}$ \\
\hline $2:=$ a ajua & $\begin{array}{l}\text { 2:- Qutando está no } \\
\text { estado sélido sassa } \\
\text { pra o stado lequde. }\end{array}$ \\
\hline 3:- G goudena & 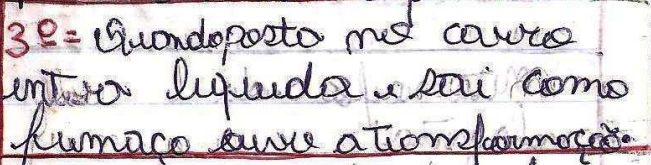 \\
\hline 40.0 late & $\begin{array}{l}\text { 4. el quatha y fica } \\
\text { osudo. }\end{array}$ \\
\hline 5: = Madoira & $\begin{aligned} & 58 \text { depas de quema } \\
& \text { del fura cómpos. }\end{aligned}$ \\
\hline 6. - nafutatina & $\begin{array}{l}\text { 6. Passa do estado calido } \\
\text { divetis para o gavoso. }\end{array}$ \\
\hline $70=Q$ Quro & $\begin{array}{r}7 \%=\text { esposto ov foy ele } \\
\text { durite. }\end{array}$ \\
\hline 8:- O gusoo wate & 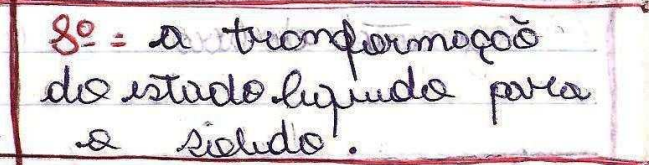 \\
\hline $9^{\circ}=$ Q cauna & 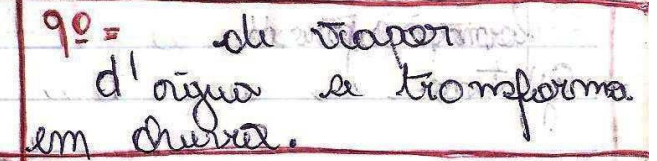 \\
\hline $108=0$ alcall bat & 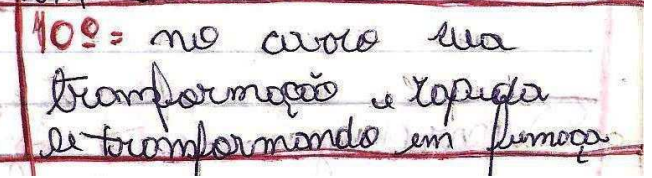 \\
\hline
\end{tabular}




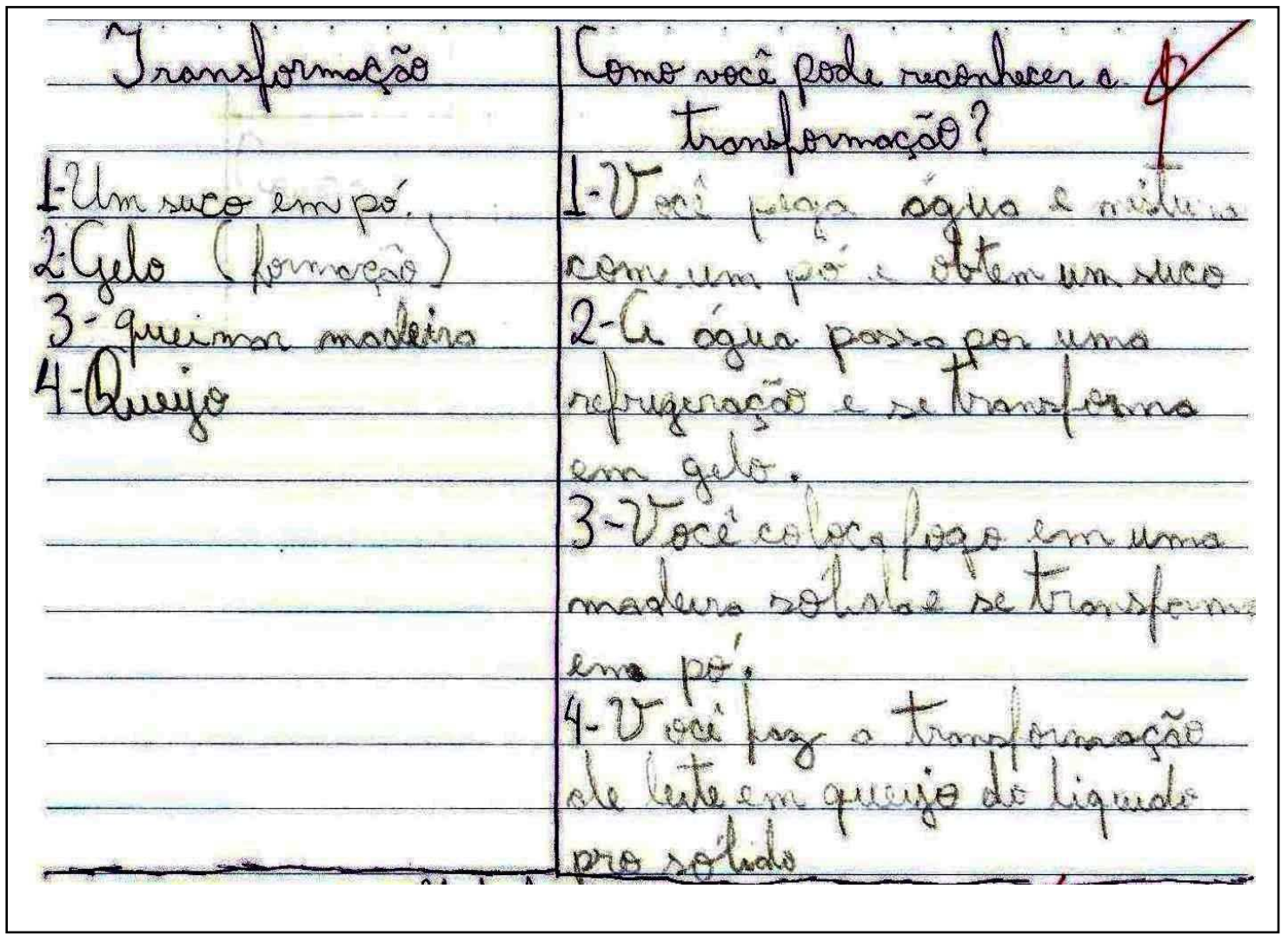


ANEXO E8 - Tabelas individuais focando as evocações referentes ao processo de desenvolvimento das plantas.

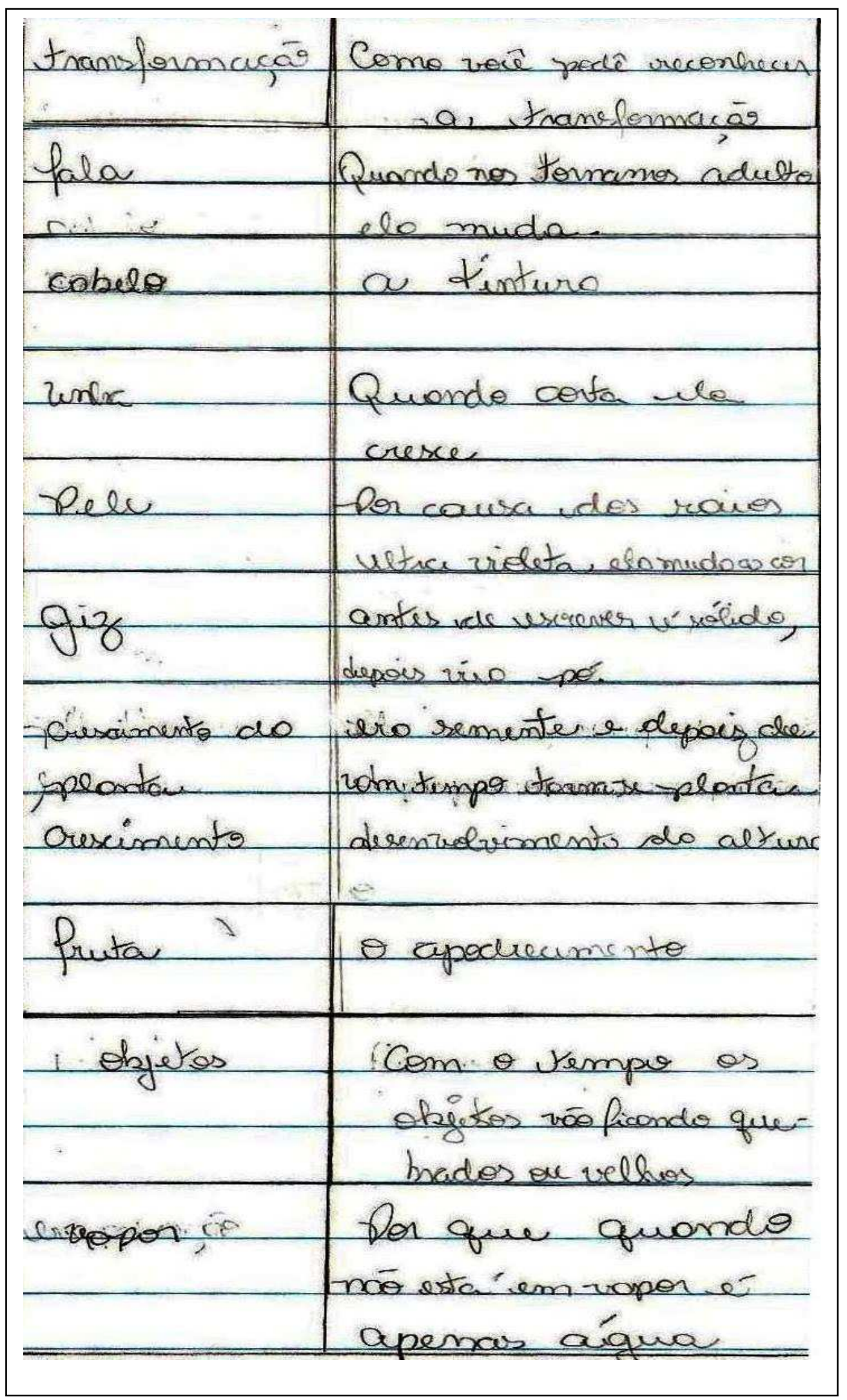


Anexos

241

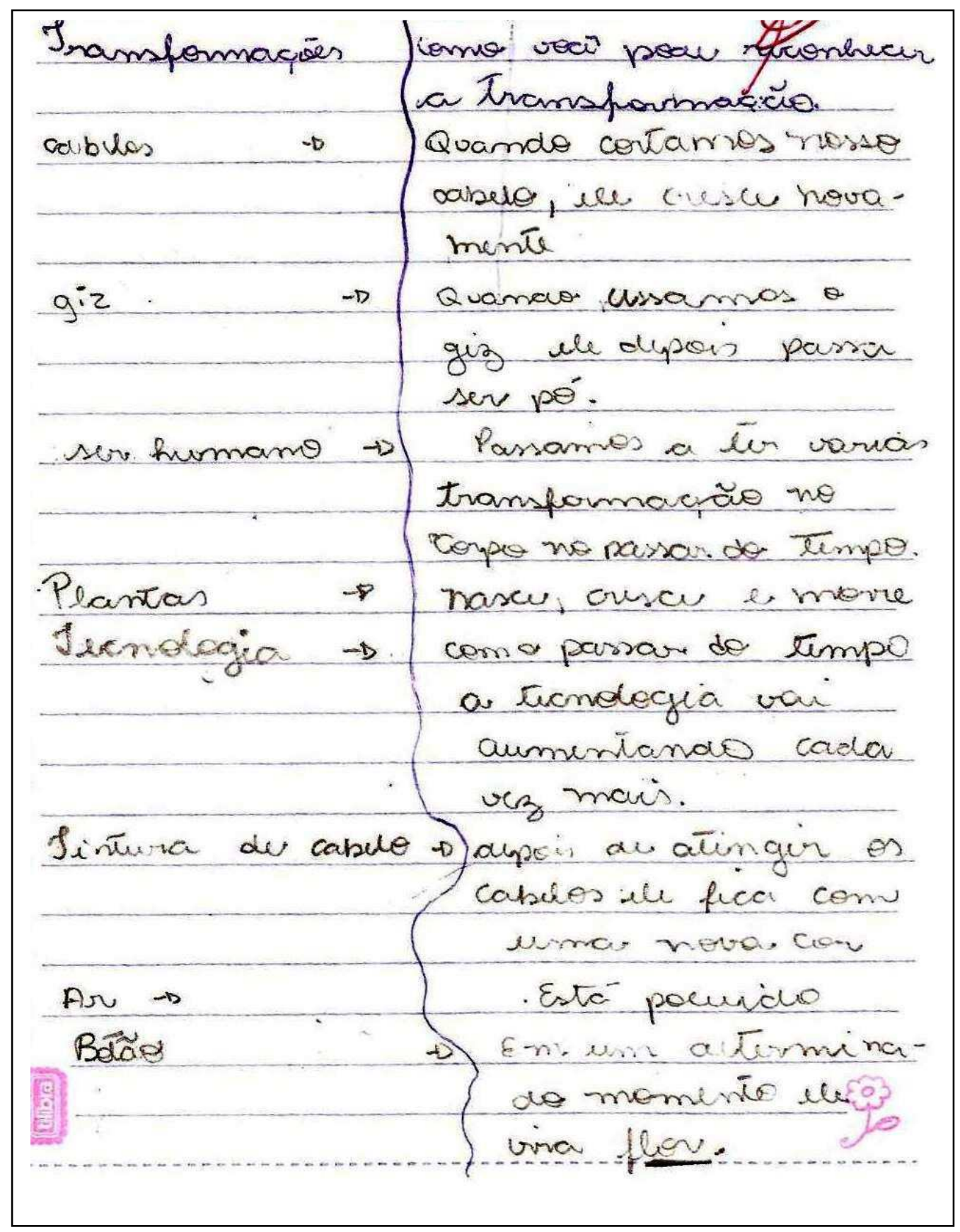


Anexos

242

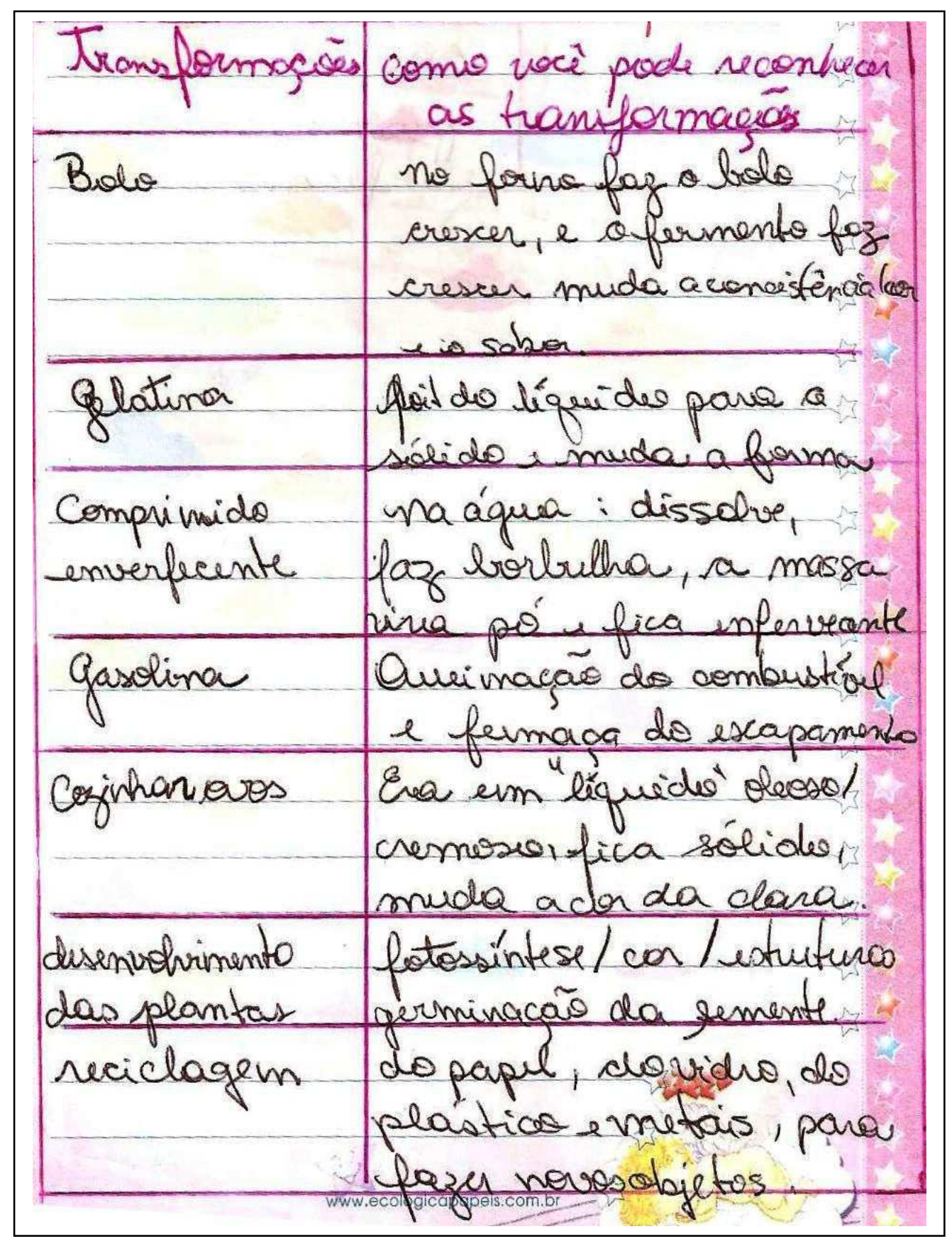




\begin{tabular}{|c|c|}
\hline Trans formacäo & Come vocé pode ri \\
\hline $\begin{array}{l}\text { egintues } \\
\text { unn ovo }\end{array}$ & $\begin{array}{l}\text { A cor muda, ila genne indu } \\
\text { rese, e gosto muda. }\end{array}$ \\
\hline $\begin{array}{l}\text { winhar } \\
\text { inm belo }\end{array}$ & $\begin{array}{l}\text { Obolo fico consi } \\
\text { do um pouce }\end{array}$ \\
\hline Ruoniveros & $\begin{array}{l}\text { unsivivmer sicis } \\
\text { gos colarnico. }\end{array}$ \\
\hline $\begin{array}{l}\text { cuscimente } \\
\text { de umo flonts }\end{array}$ & $\begin{array}{l}\text { A ceer mude } \\
\text { de plento mu }\end{array}$ \\
\hline $\begin{array}{l}\text { Un comprimides } \\
\text { mo ogucia }\end{array}$ & 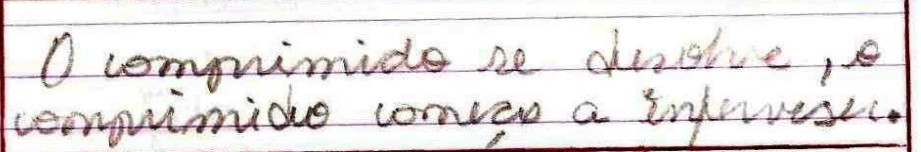 \\
\hline coginhor come & A wr mudo, gusto muda. \\
\hline $\begin{array}{l}\text { uginher withe } \\
\text { de nipoes }\end{array}$ & $\begin{array}{l}\text { Wile de un, gosto } \\
\text { nocio e evocoste. }\end{array}$ \\
\hline $\begin{array}{l}\text { Dita uma } \\
\text { crimha }\end{array}$ & 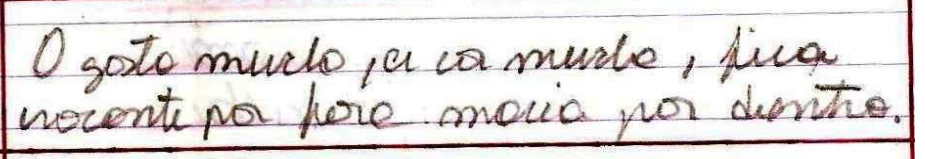 \\
\hline $\begin{array}{l}\text { Vonc muto } \\
\text { em } \\
\text { movimento }\end{array}$ & $\begin{array}{l}\text { O combustivel queima o olio } \\
\text { tombón, poi humoen plo } \\
\text { scopiomenti. }\end{array}$ \\
\hline $\begin{array}{l}\text { Fazor } \\
\text { Chapianua } \\
\text { ma unelos }\end{array}$ & 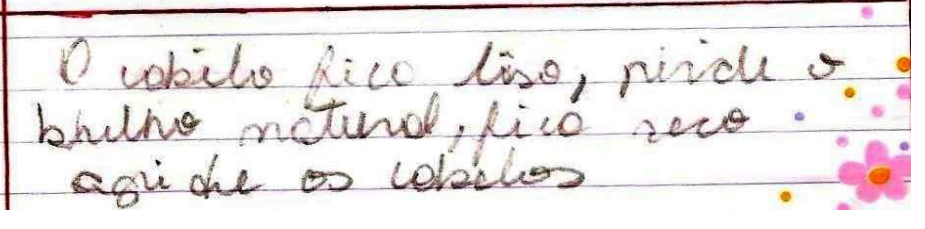 \\
\hline
\end{tabular}


ANEXO E9 - Tabelas individuais focando as evocações referentes ao processo de fermentação

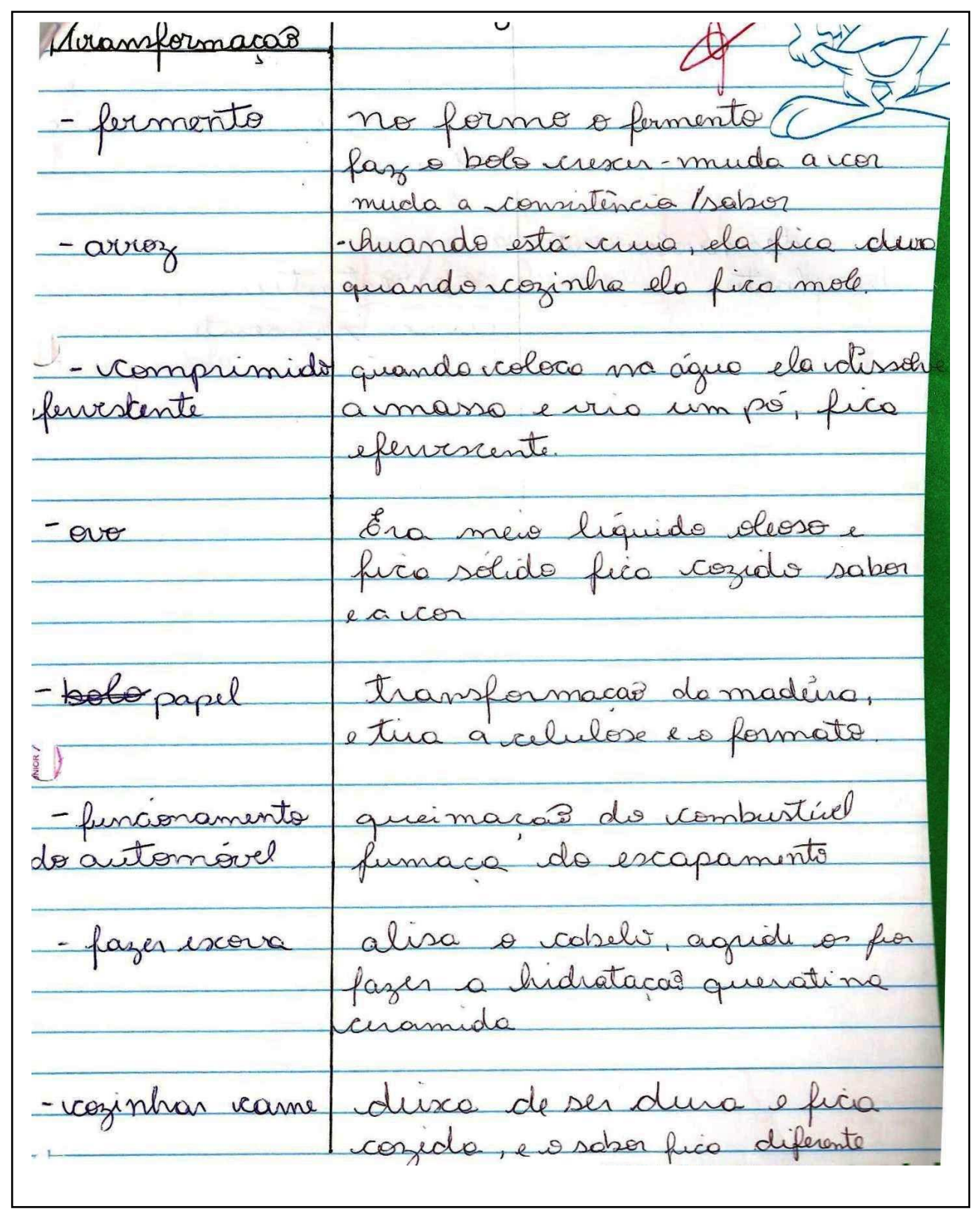




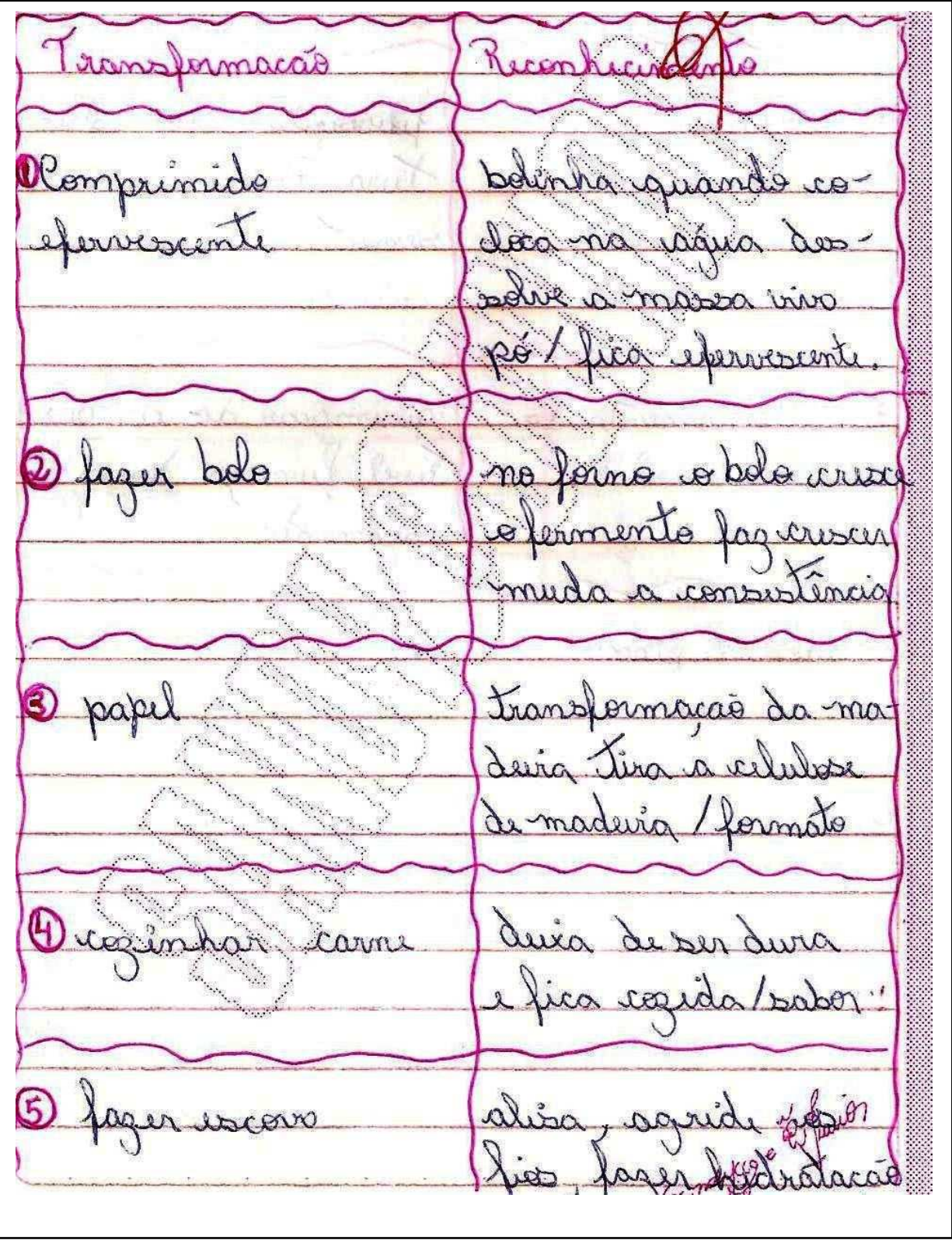




\begin{tabular}{|c|c|}
\hline thansformaciāo & Teconhecimente \\
\hline Oprmento & $\begin{array}{l}\text { Ocrescimento do páo através } \\
\text { do permento }\end{array}$ \\
\hline Osaigênio x g carbonico & $\begin{array}{l}\text { rospina asagenio e espina g } \\
\text { carbonicce }\end{array}$ \\
\hline Cozinhan carne & $\begin{array}{l}\text { deisca de sen dura e fica cogida } \\
\text { sabon ena maio liquido e fica } \\
\text { salido pion couide./oabon/con }\end{array}$ \\
\hline milho de pipoca & $\begin{array}{l}\text { estouna, mucba de con maciol } \\
\text { orocante. }\end{array}$ \\
\hline papel & $\begin{array}{l}\text { transformacāo da madeinde } \\
\text { o pornato da'madeina }\end{array}$ \\
\hline Pazer un malo & 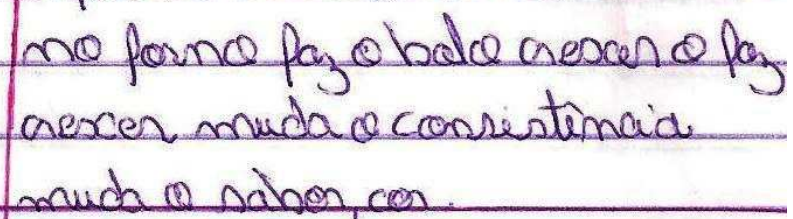 \\
\hline Banne & atraves de naves, objtos \\
\hline 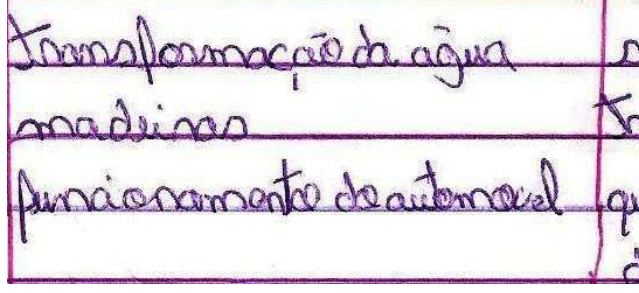 & 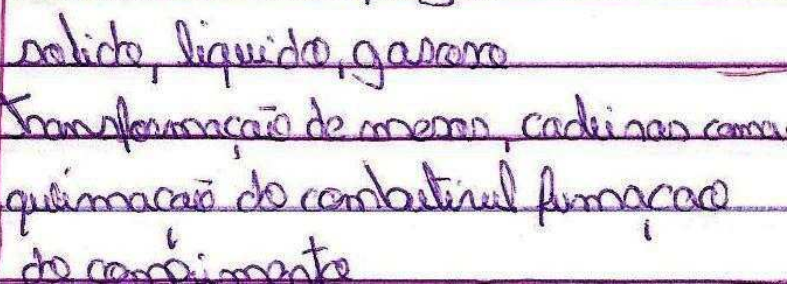 \\
\hline
\end{tabular}


ANEXO E10 - Tabelas individuais focando as evocações referentes a café e leite, água e suco em pó, barro + água e detergente ou sabão em pó

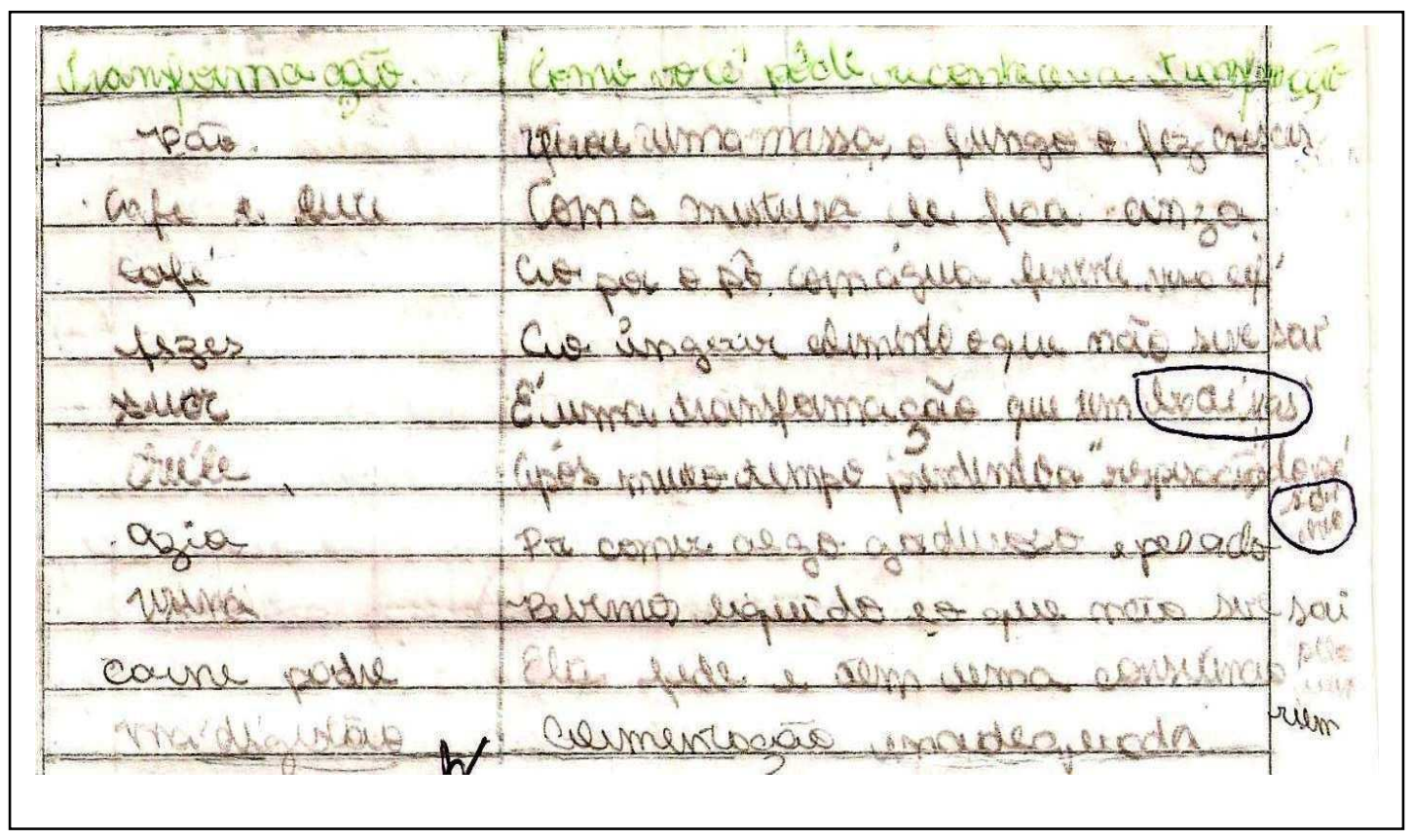

\begin{tabular}{|c|c|}
\hline Jranslermacaio & Comor voce pode reconhecer as transformacăor? \\
\hline Jintura de cabelo & Depoir de tingidos, or cabelos licam com umav novov cor. \\
\hline Batur um holo & Quando alocader no formo, le anncu e ficau solido. \\
\hline Áquar e suco em pó & Quando misturados a áqua se tramsermes enu suco. \\
\hline Milloo de papacen & Iom contato com levo quente, ele se tramplorma enm neipoca. \\
\hline Gräs de fiñar & Quando cozido, ele se toma comestivel. \\
\hline Botāo de rosa & Em wim deternimado memento, ele se transferma en rosa. \\
\hline Gizg & Quando wamers a gix, ele se desegenta e vira pó. \\
\hline Ar & Eostá poluido. \\
\hline Crexcimento dou planta & $\begin{array}{l}\text { Gora semente e depoir de um tempo ela se tomou uma } \\
\text { planta /árnore. }\end{array}$ \\
\hline Unina & imada ela torna a crescer. \\
\hline
\end{tabular}


Anexos

248
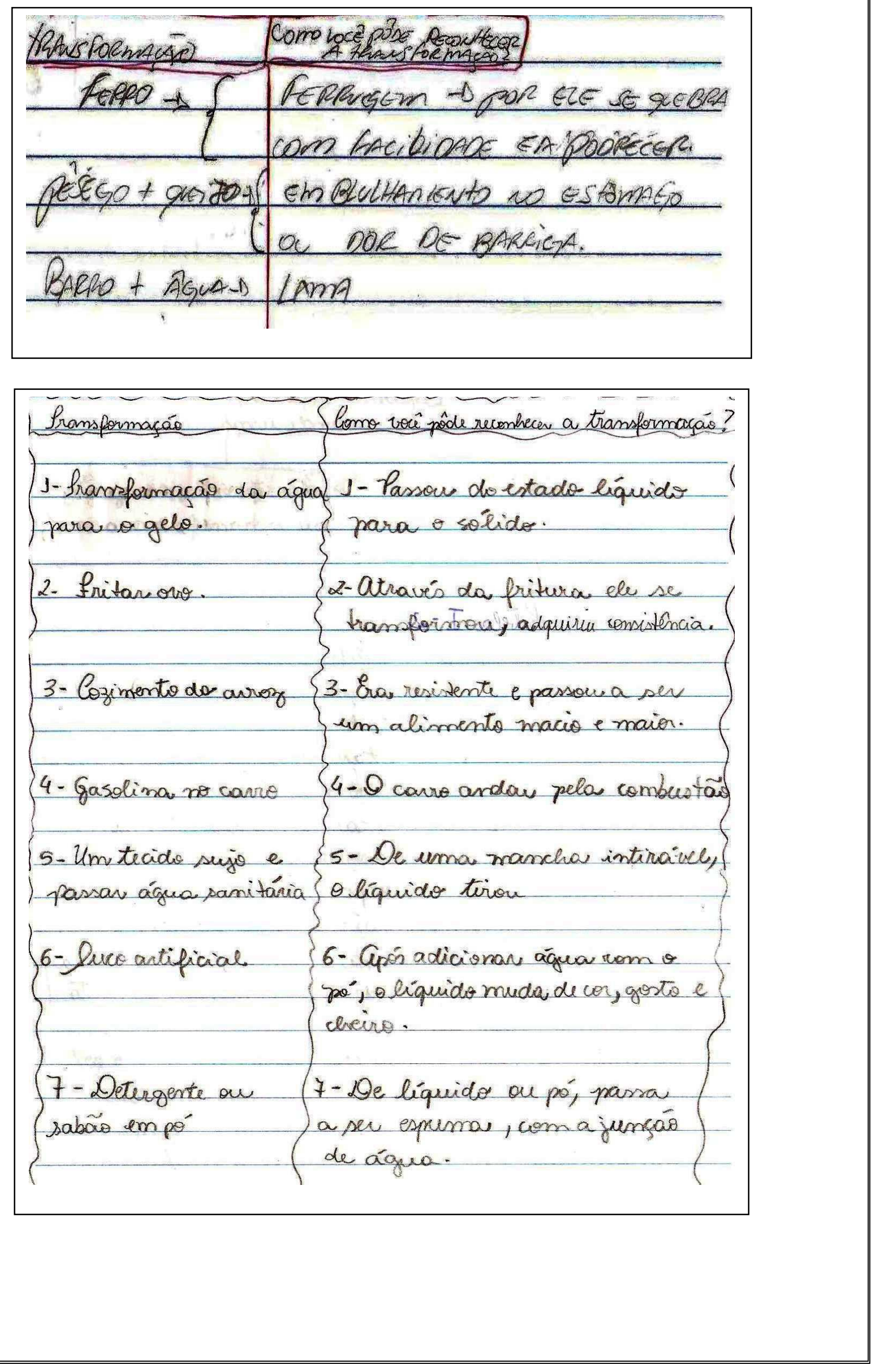
ANEXO E11 - Tabelas individuais focando as evocações referentes sol e dia

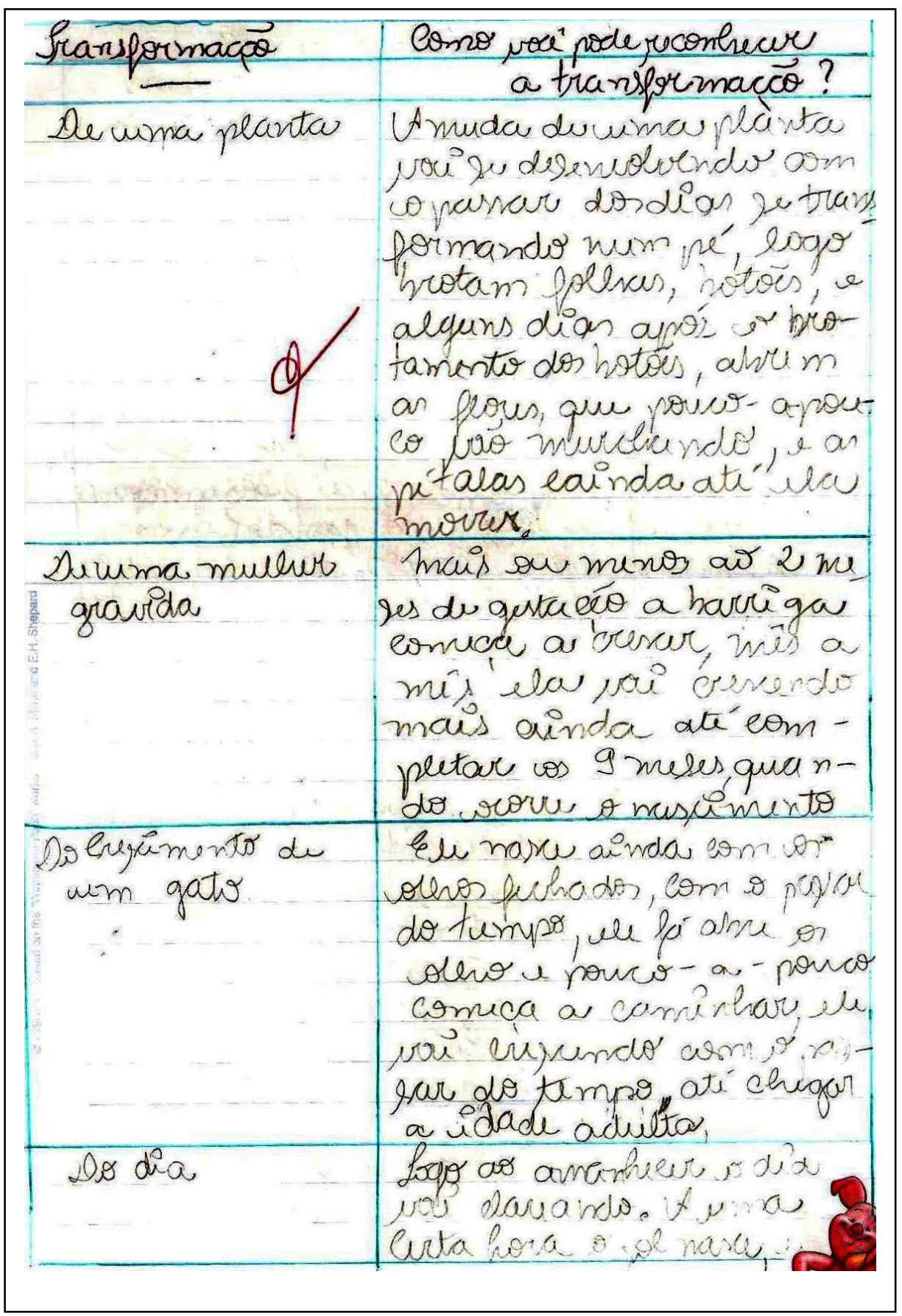




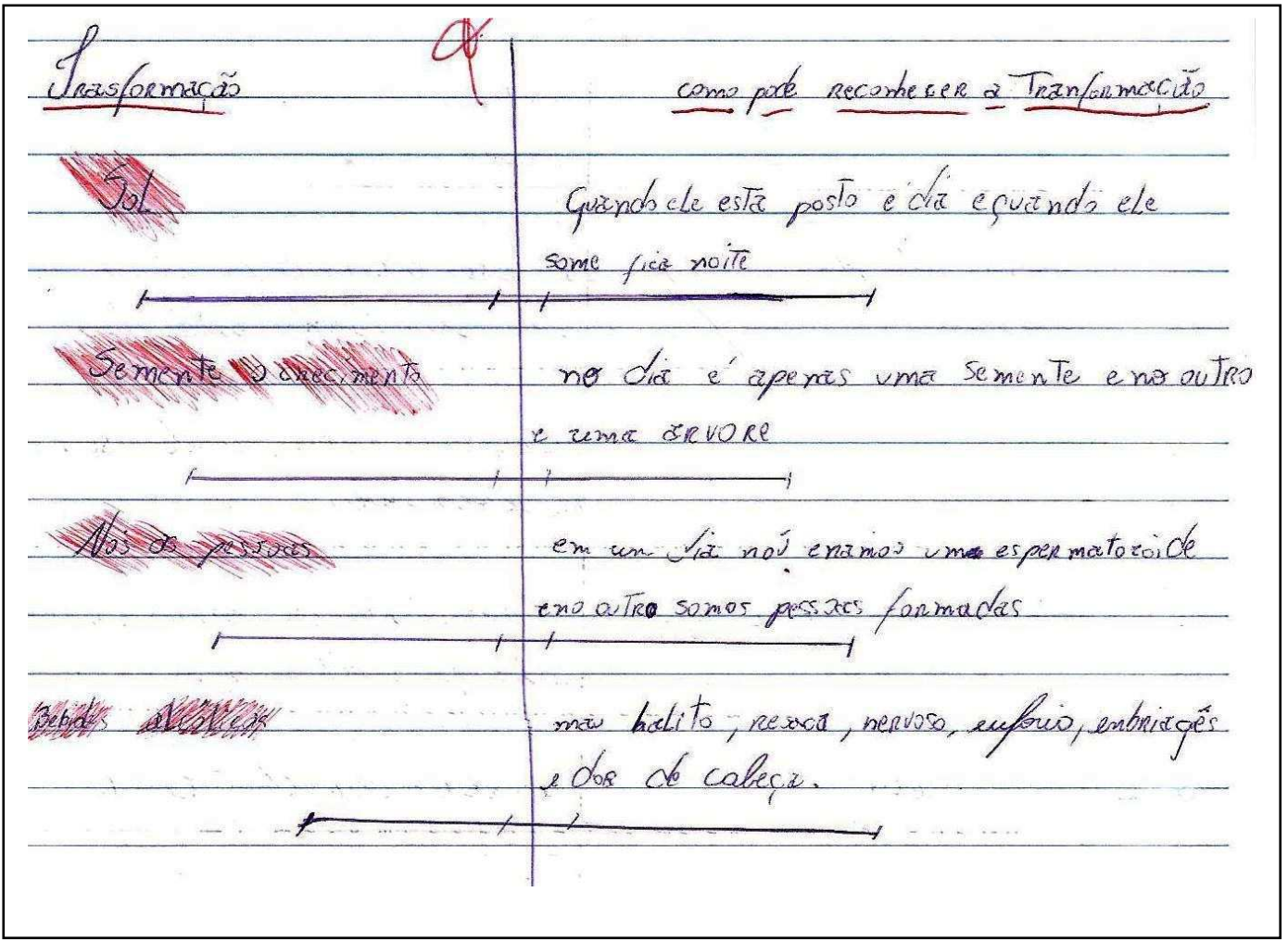


ANEXO E12 - Tabelas individuais focando as evocações referentes a dentes e café

\begin{tabular}{|c|c|}
\hline Thomplormocine & 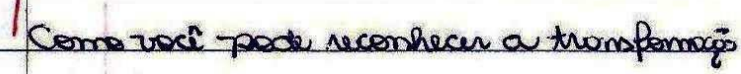 \\
\hline - Tempo nublodo & O céu carregodo \\
\hline Os dentes & depois de comer está sujos \\
\hline as mios de comunicocas & Agar tudo i mais facil \\
\hline$A_{n}$ & Agora é muits mais poluids \\
\hline Criomca & se crionca para homem \\
\hline botao & Nepois tria uma nowa \\
\hline Cabels & A peskoo peote, muder de cor \\
\hline lópis & de tants apontar acoba. \\
\hline mielo & sepois de fito vira pipeca \\
\hline sesento & Aperrea pode colvair. \\
\hline
\end{tabular}

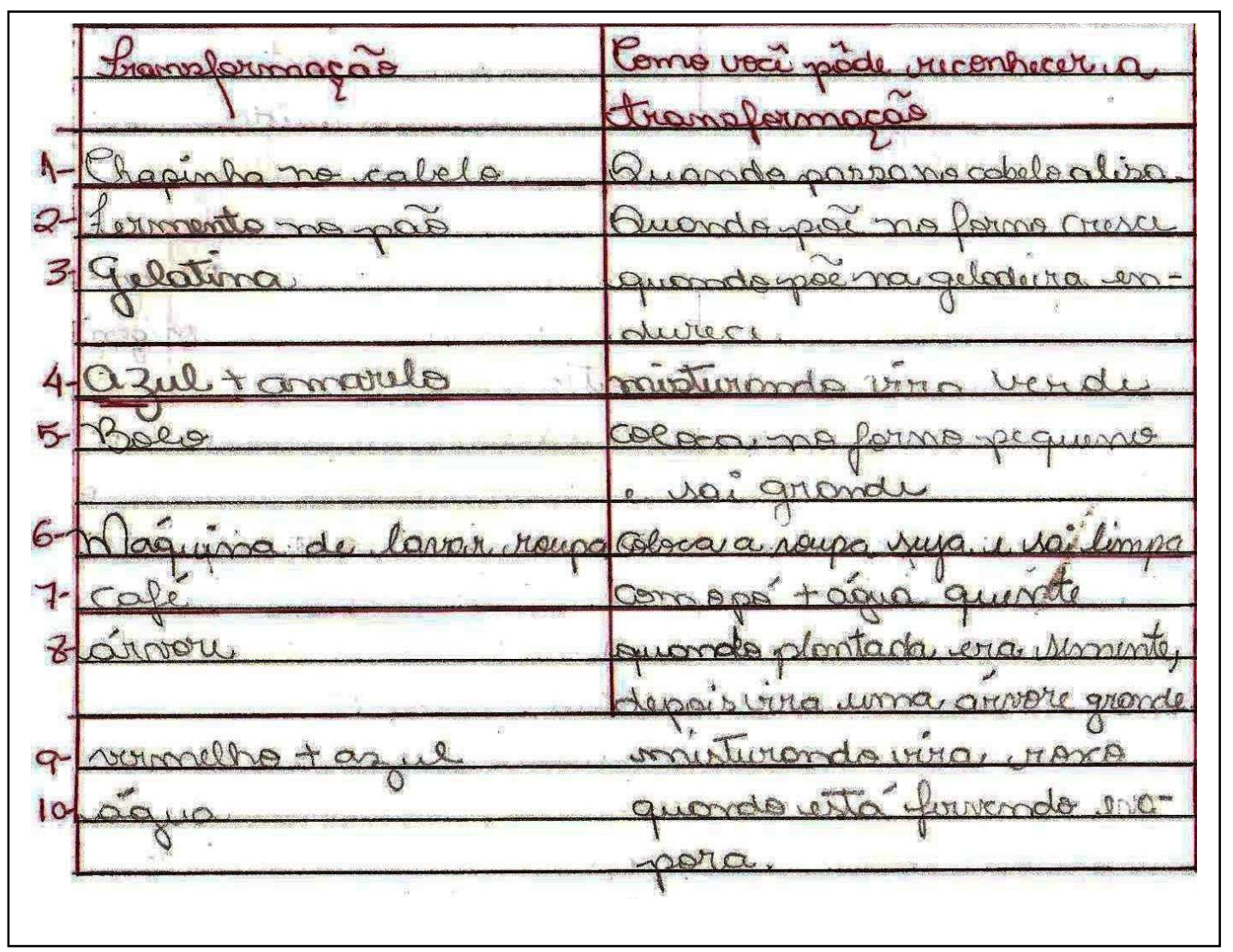


ANEXO E13 - Tabelas individuais focando as evocações referentes a decomposição

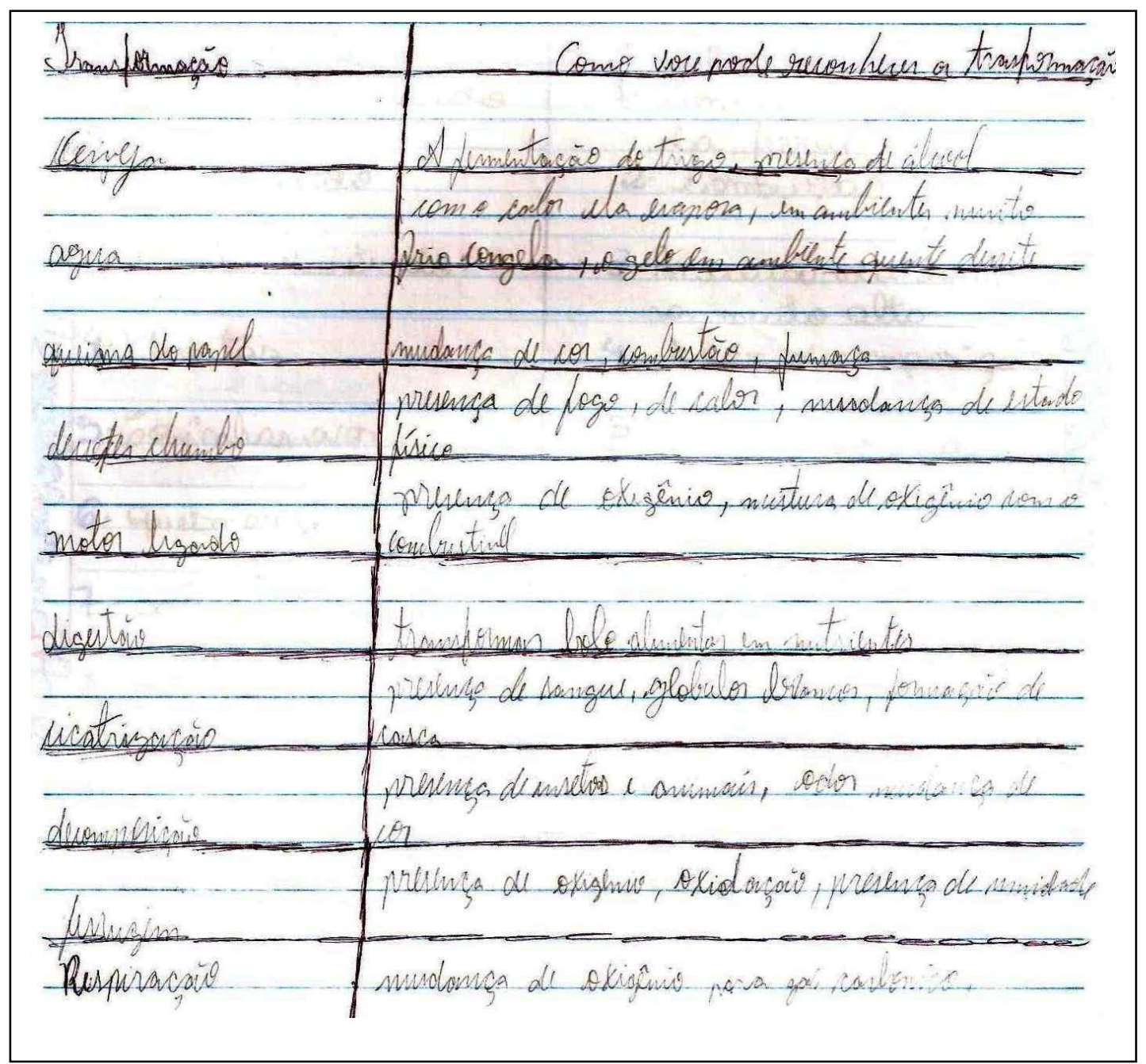

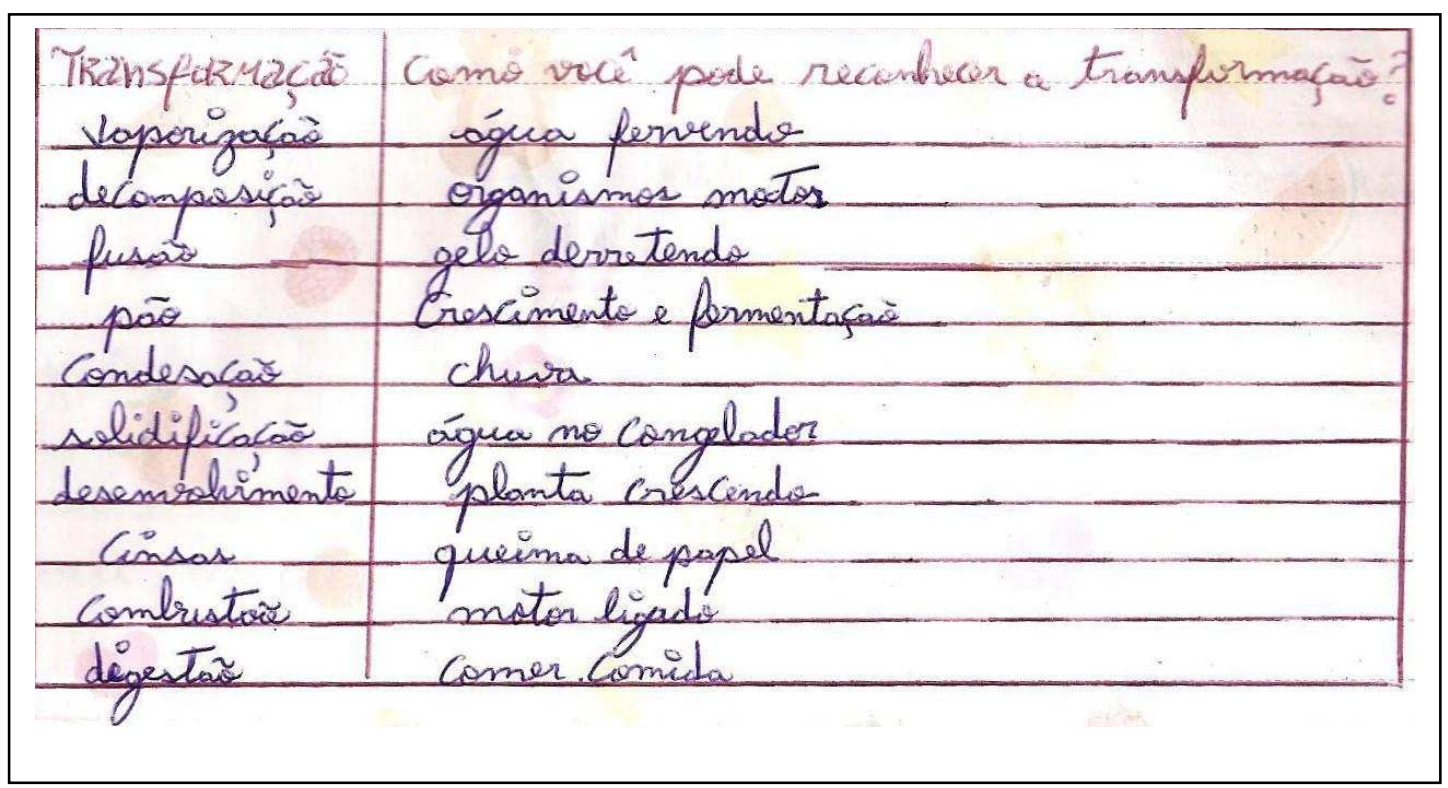




\begin{tabular}{|c|c|c|}
\hline \multicolumn{2}{|c|}{ Transformaças } & Como foi reconhecido \\
\hline 1 & decomposiças & $\begin{array}{l}\text { desmancho, cheiro, pedoges, } \\
\text { animais em volto. }\end{array}$ \\
\hline & $\sigma u$ & (2) \\
\hline 2 & pas & $\begin{array}{l}\text { fermento, escurece, } \\
\text { oresce }\end{array}$ \\
\hline & $n$ & 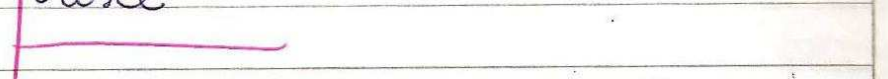 \\
\hline 3 & digestass & $\begin{array}{l}\text { suco gástruco, diluiças dos } \\
\text { alimintos }\end{array}$ \\
\hline & $n$ & $-n$ \\
\hline & $\begin{array}{l}4 \text { - corte ma pele } \\
\text { - " }\end{array}$ & Sicatriz, madonco de por,. \\
\hline & $\begin{array}{l}\text { 5- fumacio de } \\
\text { ônibus }\end{array}$ & liberacps de gás, cheiro, cor \\
\hline & $-n$ & $\overline{-}$ \\
\hline & $\begin{array}{l}\text { 6- peruto prescendo no } \\
\text { árvore }\end{array}$ & lammanho, cor, gosto \\
\hline- & $m-$ & - \\
\hline & $\begin{array}{l}\text { 7-queima de } \\
\text { pnew }\end{array}$ & $\begin{array}{l}\text { cheiro, cor, fumac, consistênico } \\
\text { derrete }\end{array}$ \\
\hline & m & 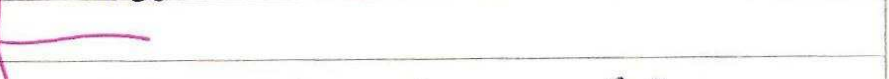 \\
\hline & 8-refrigerante & misturo de gás com léquido, \\
\hline & $\begin{array}{l}\text { 9-reloxamento } \\
\text { no cobelo }\end{array}$ & $\begin{array}{l}\text { aliso, tescturo, cheiro, loma- } \\
\text { tho }\end{array}$ \\
\hline
\end{tabular}


ANEXO F - Atividades dos educandos dos anos letivos de 2006 e 2007, utilizadas como exemplos, nas quais constam suas respostas para a segunda atividade propostas como fonte para coleta de dados e análise das etapas de formação do conceito de transformação.

ANEXO F1 - Respostas dos educandos para os Exercícios do Capítulo 1, onde encontramos algumas justificativas de reconhecimento de reação química.

1-1 Aquan - s unsigids grimetho num thrso de unsoio. Depour de olgum thrnpo de oquncinmito ditutin-k o liberocos de

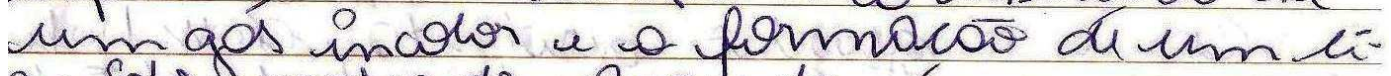
quido profeods - Purgenta - se

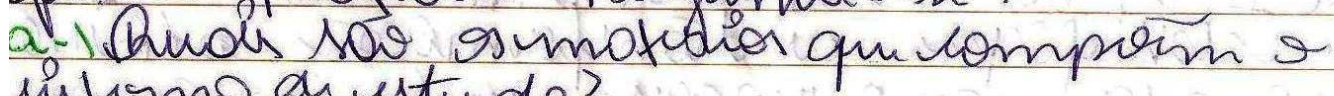
sulimo a ustudo?

thbs de unvis, lomporime (fogs) i im dolido verimiles.

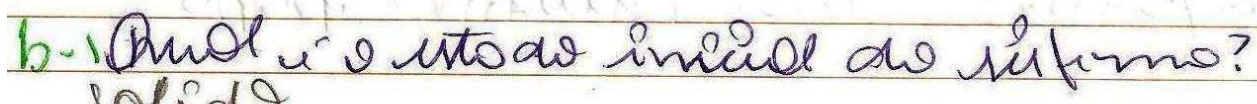
lolido

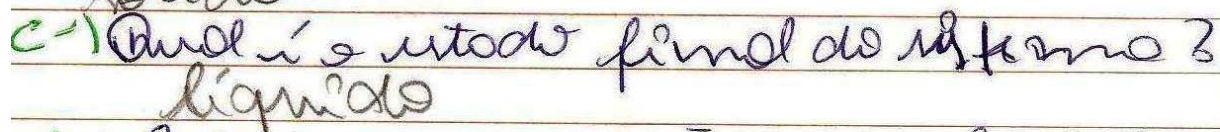

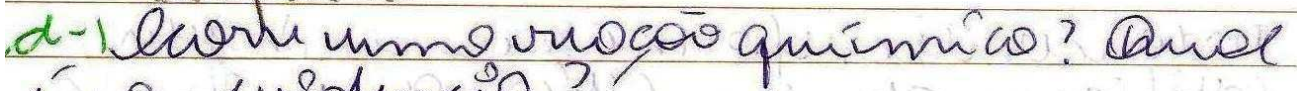
íc huidumia?

sim, stiv unm dohidw vermeles que or dajou de oquádo liburon um got

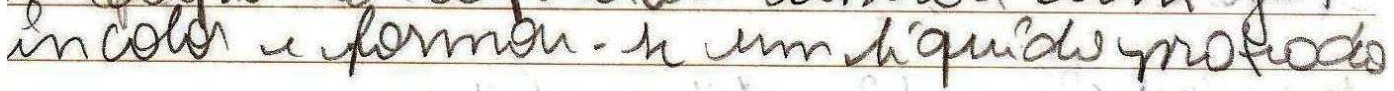

2. Durondo unm comprimido de vonsiole ícolocodo uno ogua ocon um proust gu umi ruocóo dpuímico? \&xpliqun.

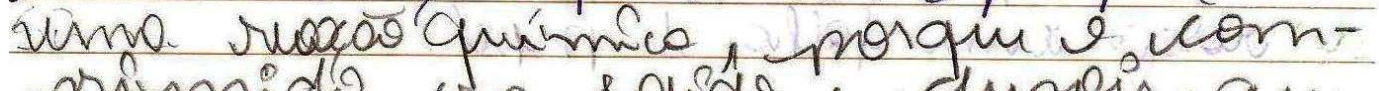
rivmido who sonóds e dypois qu

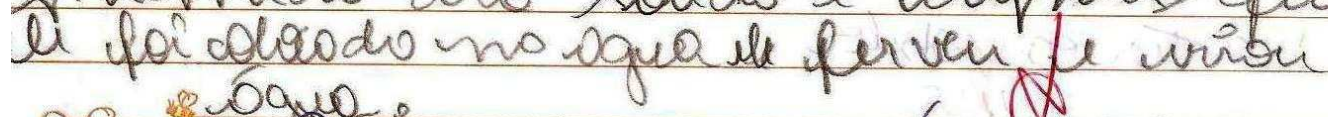

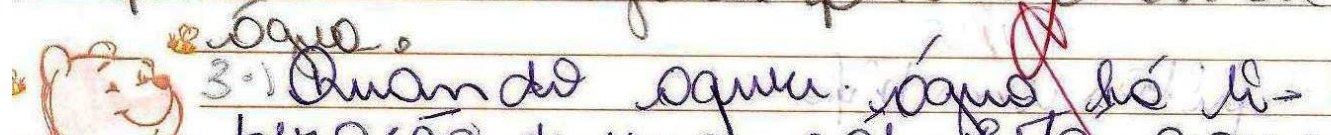

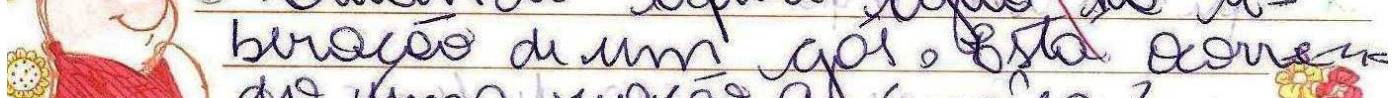
do uno juacóo qhímnica? Expliquil. 
Anexos

255

(1) Aqueceu - se em solido vermelho num tubo de ensaio. Depois de algum termpo de aquecimento detectou se a liberoçáo de um gás inador e a formacío de um líquido prateato. Perguntarse:

a- Quais são os materiais que compöem a sistema em estudo?

um solido vermelho.

b. Qual é o estudo inicial do sistema?

solido, vermelho

c- Qual é o estado find do sistoma?

gósincolor, formaçá de liquido, prateado

d- Ocorreu uma reacá quimica? Qud é a evidencia?

Sim, pela mudanca decor

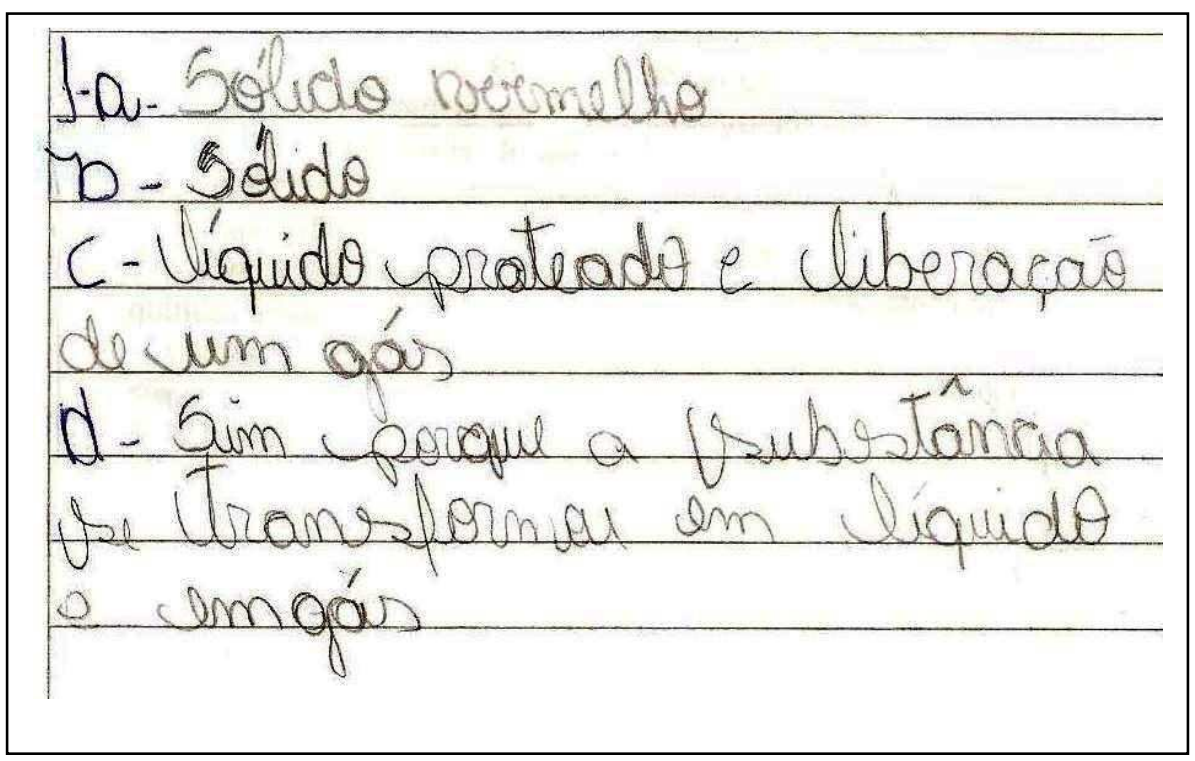


(a)

a) um sólido vermelho e un tuls de enraio

b) Um sólido vermelho

c) Un líquido prateado.

d) Sim pois alterou a estrutura da materia. Era un sólido vermelho e viou un liquida protedido.

(1) $a=$ Um dide revmelhe noum tribs di. unsair.

bt Jóle do wronlio

k-l émor Miquido plik do

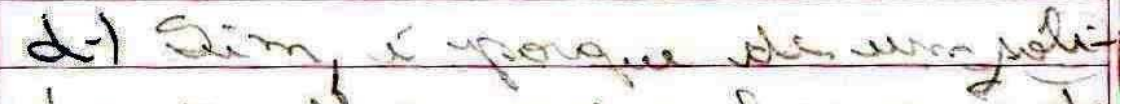

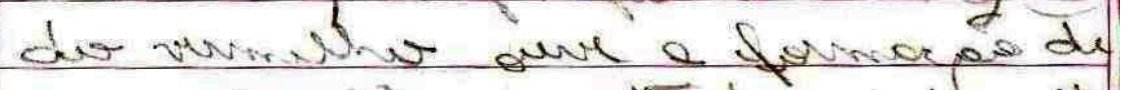

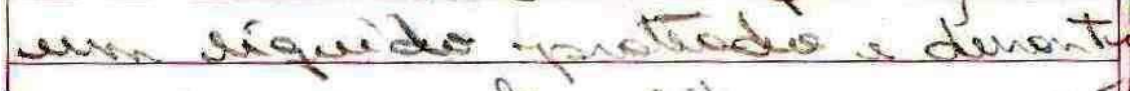

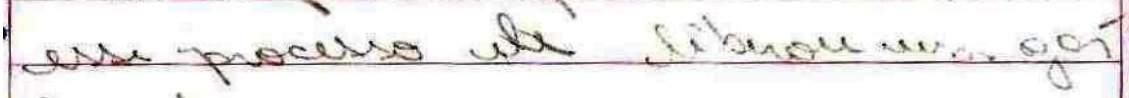
incolo. 
1) al solido vermolho, gás incolor e um liquda prateado b) solide vermetho

c) liquílo pratedelo

d) Sim pois cem o aquecimento do malerial solido ele libera um ga's incelor e logo depais há a formacāo de up liquido pratrado, ou Seja, a substáncia que da coloraczao a ma terial se desprende stevido do aquecimento se torna un gés inder

Ia) Sólido vermello.

b) To ustado vinicial lé wom vólido vermelho.

c/ no ustado final el vira um líquido prateadoo

el vecorreu poir vouve uma unova usubstância ol sólido pa ra líquidolo 
17 a' nolide vernaller e o tubo de Envores

b7 bivo

c) Lípiotes

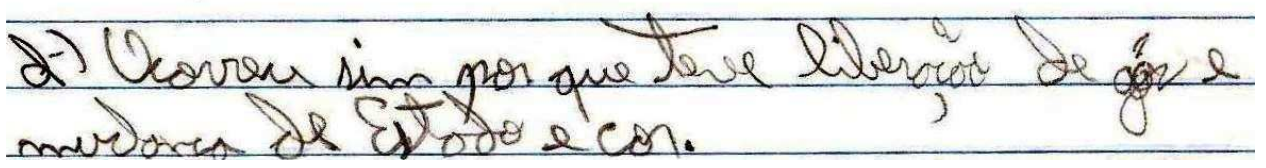

1-a) fólido vormulho wo líquido pratiado.

b) Lim selido vermulhe

0) formajao ve um liquido prateado.

del fimpoiparsou do lólido para o liquido liberou gares e mudoe de cor de vermelho passou a ser apratiado. 
ANEXO G - Atividades dos educandos dos anos letivos de 2006 e 2007, utilizadas como exemplos, nas quais constam suas respostas para a segunda atividade propostas como fonte para coleta de dados e análise das etapas de formação do conceito de transformação.

ANEXO G1 - Respostas dos educandos para os Exercícios do Capítulo 1, onde encontramos algumas justificativas de reconhecimento de reação química no processo de aquecimento da água.

(1)

a) un sálido vermelho e um tilio de ensaio

b) Um sólida vermelho

c) Un líquide prateado.

d) Sim pois alterou a istrutura da matéria. Era un sólida Vermelho e viou un liquida pratesido.

(2) Um procenso fúxico pois não alterou a estrutura do matéría le ró mudou de estado físico de rólido para líquido.

(3) ocorre uma liberargão de gás mas não l' uma rescás química pois näs alterow a estrutu ra de matéria rómudou de estado fúxico. De liqui de para gassoso.

(4) Fenme taçáo de marra de lolo - químico Iuncionon un automovel - químice 
Ia) Sólido vermelho

b) ho ustado unicial ú wom isoéido vermelho o

c) no ustado final el vira um liquido prateado o

dl vecorreu i poir vouve uma unova usubstáncia l sólido pa ra líquidolo

2. Ocorre um usubstância rquimica, porque vira só uma substância poir vo comprimido mistura com va vágua.

3o háo perque a áqua só uvapora, ula mão divca ve user vágua o

40 fazer um bolo- químico

queimar papel-químico

ideveter vchumbo-pósico

perfreme vaponando-písico

fritar ceves - químico

Salvquímico

b) físico

h) químico

cl firico

d) físico

e) físico

fl químico

(g) fusico 
(1)

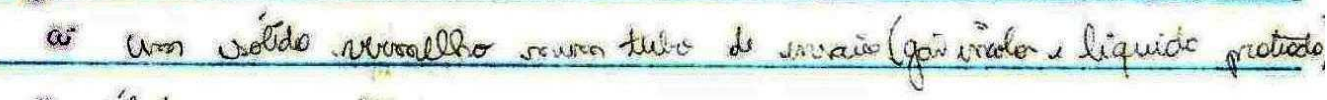
B. Sólede e vervoullio

C. Jutrar-x wom liquido proterds

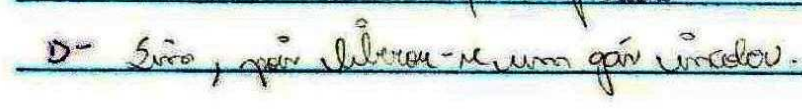

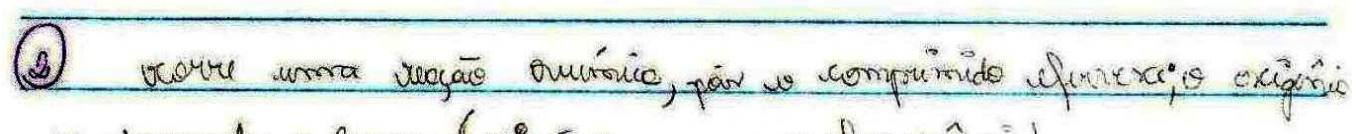

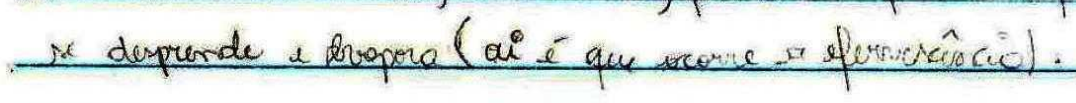

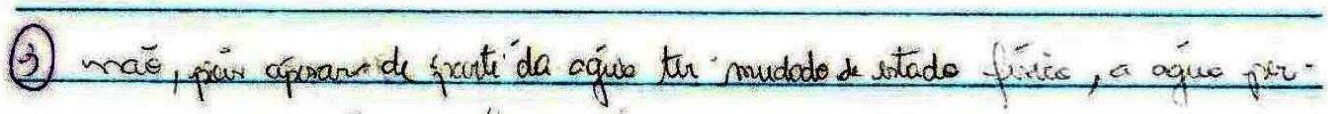

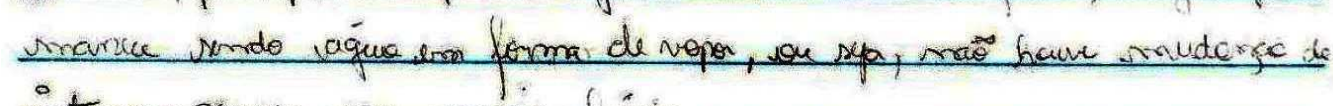

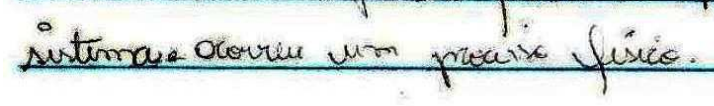

(1) fazu live to veleqaí quirivic Papel I rocão rquimico

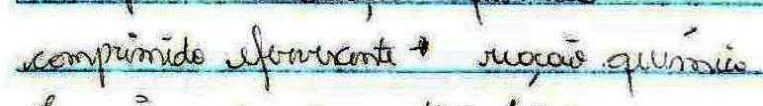

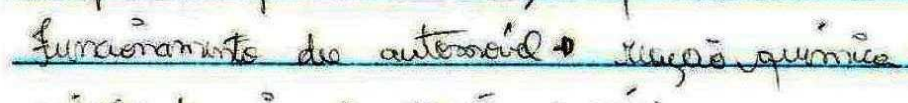

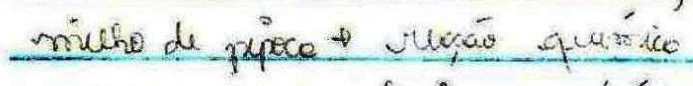

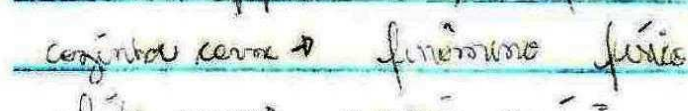

finta overt ruescás quérice

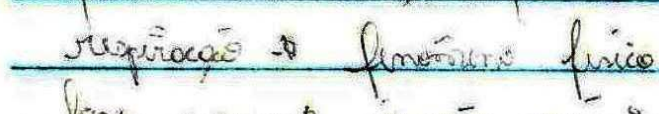

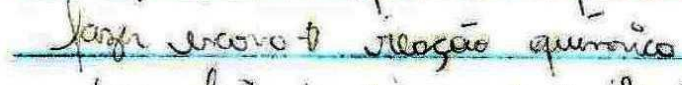

desinchimente dor sementert fenômino fúrio

(5)

(a) Surivica

(3) físic

(D) Júxia

(6) fúcec

(f) aurnice

(a) surinic

(1) fívec 


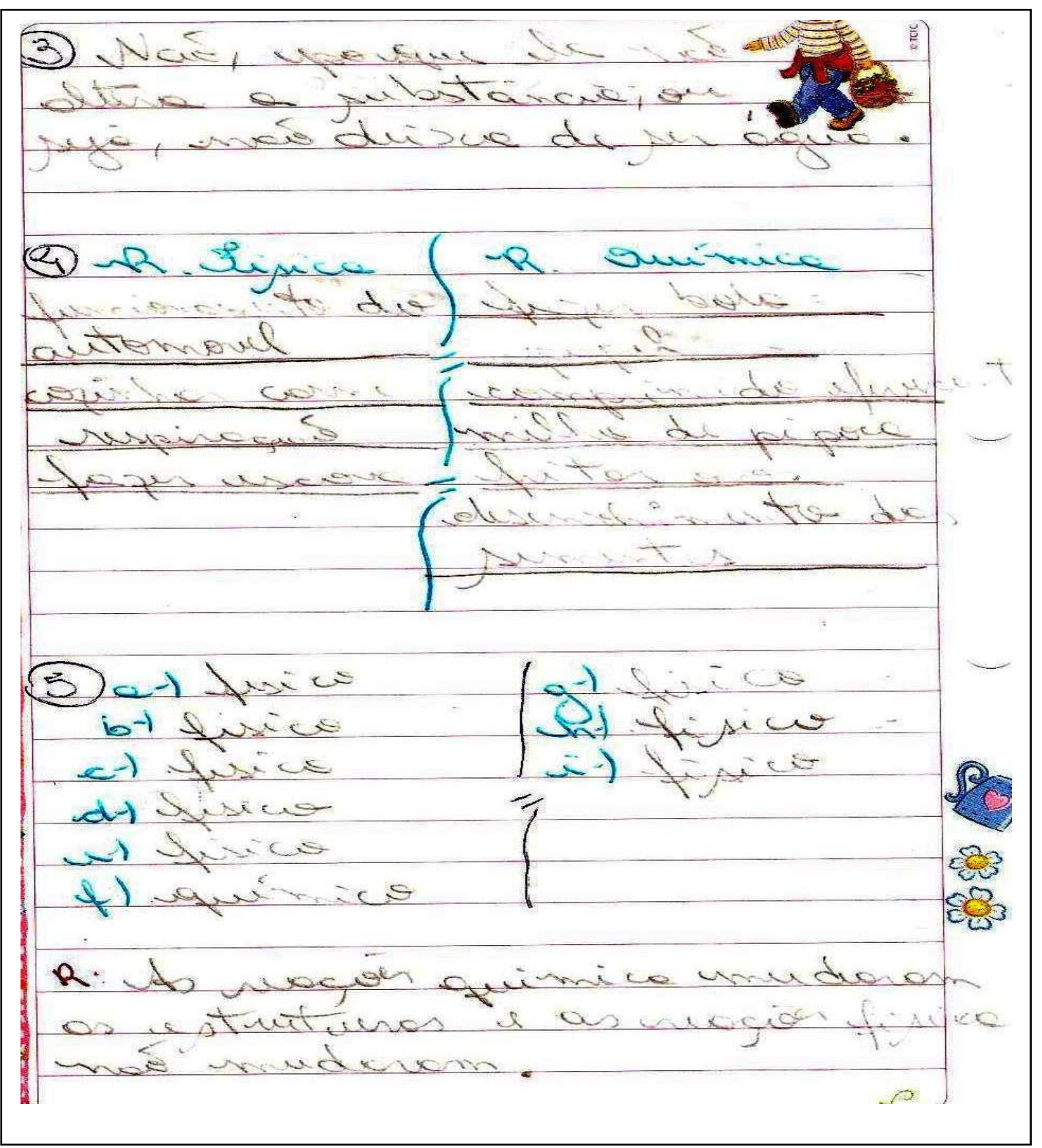


(3) Quando se aquece água há liberááa de um gásÉstá ocorrendo uma reacáa química? Explique sua resposta.

náa, pois o gás éa agua em estado gasuso

(13) Pletome o quadro gerd da classe (I-2) construílo na Atividade I-1 e dassitique as transtormapóes di relacionadas comp reapóes a químicas ou processo físsico.

19 Dadas as transformagoes a seguir, clarsitique-as em físicas ou químicas:

a-escurecimento de uma collher de prata

fisico

b-orescimento das unhas fisico

c-andecimentio de um picols de limào. fisico

diresgar una follo de papel. "I g queima de uma acha de lenta fisico

c- cortar os cabelos tivice

f fritar um bife is quimico 1 "hazedar o vinho is is i tisico «i terver agua fisico 
(1)

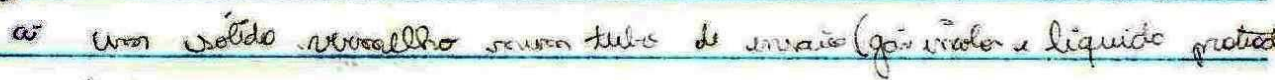
B. Solido e vursoulho

c. Jitrar - se won liquido protedo

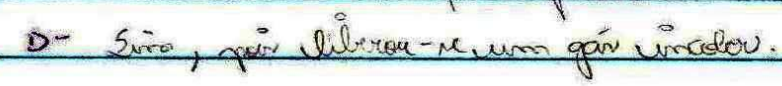

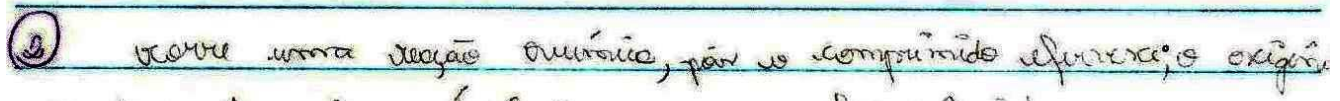

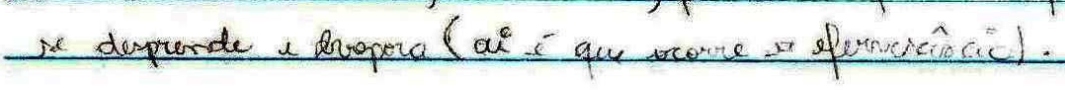

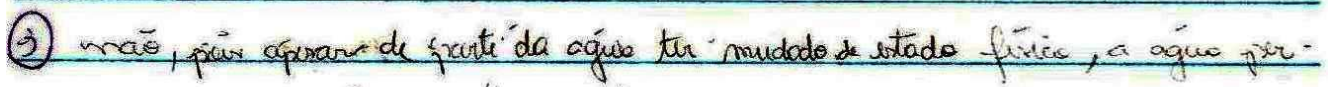

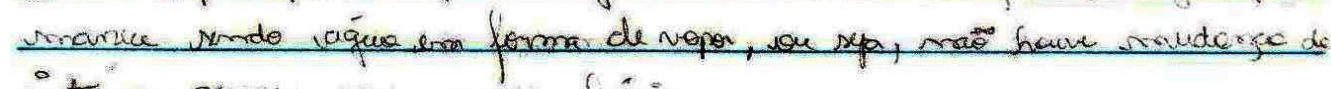

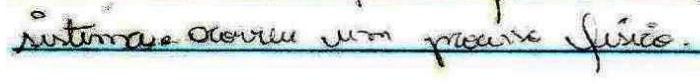

(4) fager labo $\rightarrow$ resacó quiricic

Papel a reocáo quirrice

compromide eferverante trocaio quirócie

Euncuonamints du autersoíl $\rightarrow$ rengè quimica

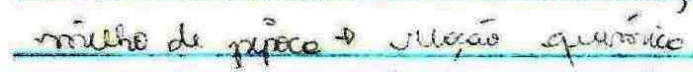

coginiau cevo $\rightarrow$ funèruno fúris

finta ovort ruckás quirvice

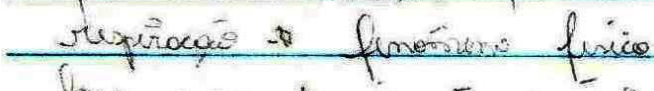

Lager var to reogáo querrico

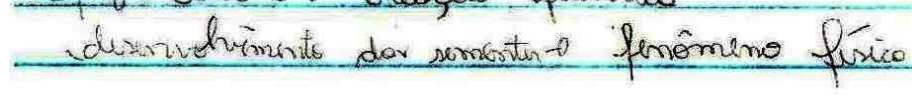

\begin{tabular}{|c|c|}
\hline \multicolumn{2}{|l|}{6} \\
\hline (a) Surivice & (E) fúxues \\
\hline (3) físico & (f) Surnic \\
\hline (C) surnius & (9) aunínic \\
\hline (D) fúvica & (i) fírico \\
\hline
\end{tabular}


Anexos

265

1

a) Um sólich vermelho num tubr de unoaw.

b) vaqueamente

c) edetectou-se a librracaí veu um gás uncilos e formacád de um lequide is preateach.

ia) Sum, mudou sele con.

2-quirmic, por que ele muda che solede para liquich.

3- Uma reacaón frisica, por que ele shave muda de porma se everpora.

A) Com vólido rum mulo.

B) D aqueciomento dos matriaivqu compoe \& Litsema.

c) A libuacão de um gás inodor va formaccá de uim uíquido pratiado.

b) Sim, a uindincia de que, do volido pasou para líquido.

Uima reacáo química por cauba da ef forréncia.

Sim. Perqu a água vaï libara now uim vapo.

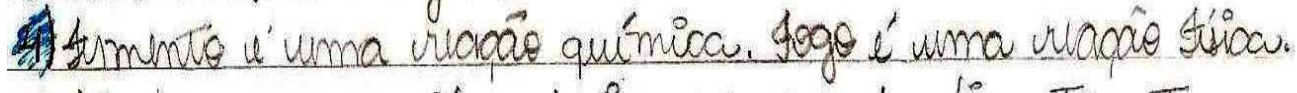

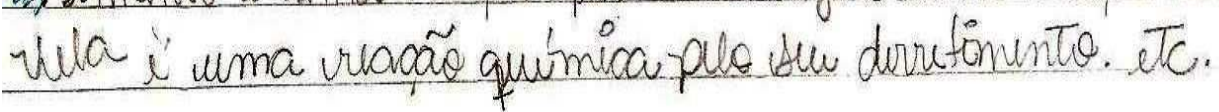


2. Quando um comprimido de pontersolé colocado em água ocorre um processo fúsico ou uma reafol quérmios? Explique sua resposta.

Dcorre unna reacos uquémica, pous of compride exfervesse bolta todos us elementos que se tum no comprimede pl podir Hozer efeito g reanédio.

3- Duando se aquece água há liberacas de um gás. Está ocorrendo uma reocps químico? Escplique sua gesposta.

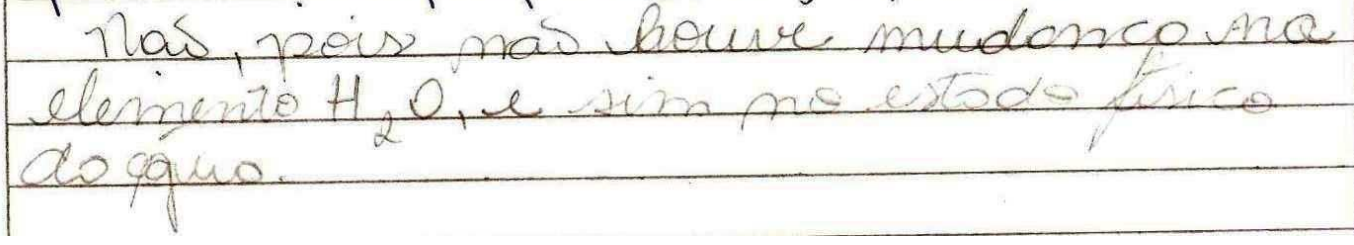

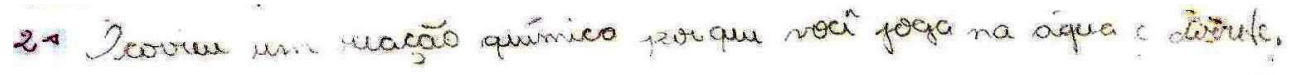

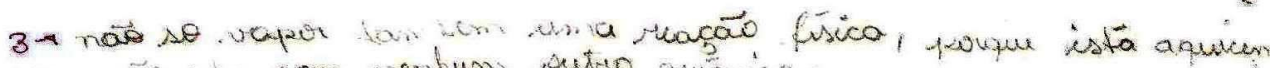
do ä usto com nentum putro quimico.

$y \rightarrow$ faner un bolo + quimico

hritar eve . Tquimica

mitho de pipeca $\rightarrow$ físico

$5+4.6$ uma reacás quinica

b-a werest fisico

C.t it arico

$d \rightarrow$ if fúsico

e- " físico

t-s reacäo anumico

g-r "q qui. ta

h- oviniso

$l=$ preasto firico. 
Anexos

267

1-a) C apostila, os subtânias, is nais impoútante atens a o na explicarä e ete.

b) e'a substancia on obreto que

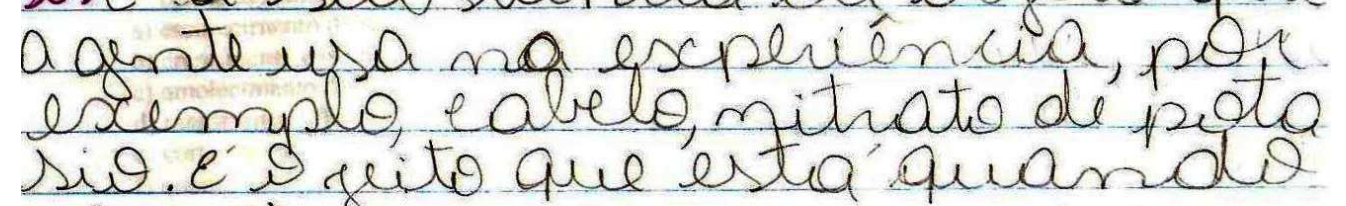
vemos.

e) É quito hinal, por excemplo, - eabet ele lica puto r com um the iro mal. Esse e'o esta. do final que percebrnos.

d) Sim olquei, e mudania de eor, de estado, do cheiro éete. 2- Durmiro, to que ele era um fompirmidor virou um po no undo do eppo ve veperpaue is emprimidiel' verferente.

3- $\varepsilon^{2}$ químico, Prque passon do estado liquudo para o solido, pa que estál virando uma tumaja. 


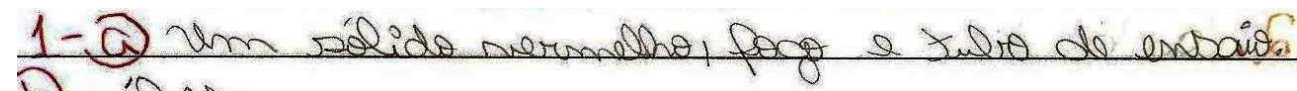
b) sqido.

c) Ríquido

D sima, que de silido picou líquido.

2-Procosso púsico-ponque aponar mudou seut Sotadi púsico pona poder un tomado mas mär a sua matéria.

3-mäo ponque apenow muda o seu estado física nar sua motónia.

$4-1=$ pinice $/ 2=$ fruire $/ 3=$ quimice $/ 4=$ químicof

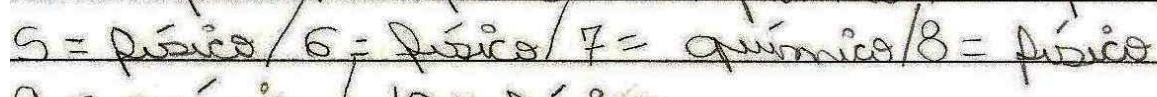

$g=$ química $10=$ písico

(a) U súlido vermeths

b) Silide vermuthe

c) Liaunde pratiado

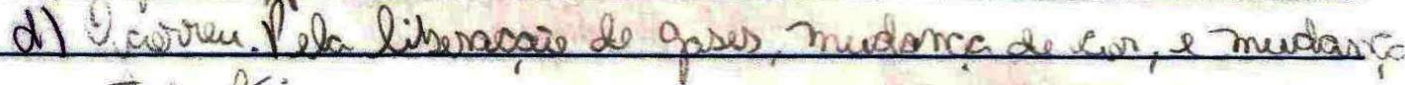
de estado físico.

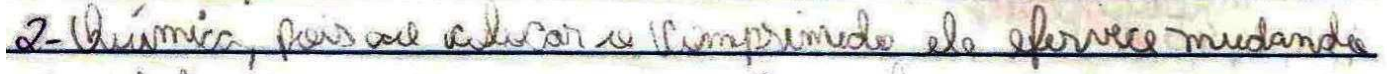

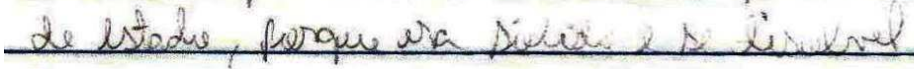

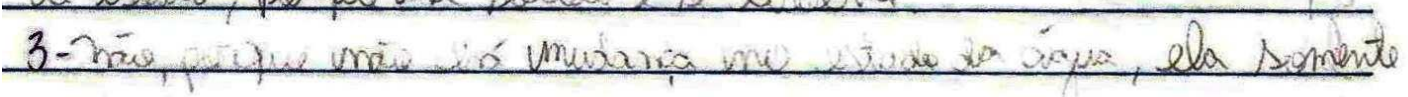
enwivones 
1-a) Aquerer um sólido vermelho no tubo de envaio.

b) Umsólido vermello

c) Liberaçä́ de um gás incolor e a formacáä de um líquido prateado.

d) Sim. Modifiore sua estrutura.

2- Reacáó fúsica. Há a tevidencia da liberacoio de gás) mas nor caso do fonrisal nä é um procisso quimico.

3- Não. Extá evaporando, mas nầ deino de set água.

4-1-Sransfermacáo da águar panar ogelo- processo químico. 2. Fritar onro- receesso químico.

3- Metameifose da lananta - procenso fisico

4- fecundarion de órulo- processo físico

5- tingimento do calele - proesso químico

6- cezimento do arrog- procenso qúsico

7- fermacáo/preparacáo do gelatina- processo químico

8 - usar drogas - proverso físico

9 - Pazer papel- precesso químico

10- desemvolvionento do sev hemano - processo físico

2. - Corr uma reacão quiñána pois só ocorre a mudanca no inicio e depois valta o normal. 3-Simp pais sob um gás e comeca a borbulhar, Iríco 4- As transformacaé são procestroquímico.

5 -

A) fésica

B) quvínuco

C) química

b) Fúsica

e) química

1) Fisica

g) quimico

h) química

i) Sisica 
(1) a) Pócinza com enocope

1) Pó amarilo, merio acunzentado

c) thicio suim, vermetho escuro, amaulo e relerde

D) istara un pó amarilo meio acementado; ie dypoes fueau en

lepindo verde, Vermetho e amarelo, com chevio ruim

(2) ocorre una uneacēo quémíca

(3) nāo, ror que a agúa só fica equente

(4) as inansfomacois são pracisso fisico

(5) a) thimíuca

B) quimica

C) qumico

b) firíca

il quemico

1) fusuro g) gumisio

hi quentico

i) Jusco.

2") Nearấ química puess s senrusal se musturas

com a água logo ocovreu uma jusä́ (alturacä). untura

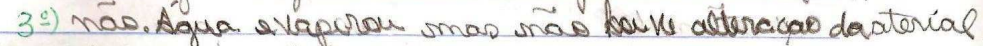

atomo"da água $H_{2}$. A água pode Ju-se vapo.

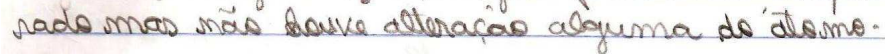

4.) testo 1-trans formacpio quimica

vda

lesto 2 - Juans formacá químsca

teste 3. puscesso júsico

tost 4 - thangformacas quimica

terts 5 - procerso fisico

tente 6 - thansformacas quimica

testo 7 - pucesso fisico

teste 8- vocusso fisico

testeg - procosso jírucs

teste 10 - turansformacas quimica

teste 11. transjormacas quínica

terte $12^{\circ}$ procerso fúsico

teste 13- procosido júsico

5.) a) jisico

b) procerso fúsico

c) quimice

d) procerso jísico

e) físecs

F) químias

G) fírico

H) quémico

i) Iusico 
(2) Reacã Quimita, pois Dão dois reagentes qué após cu mistura gera um produto, na qual podemos woó-lo, futo dussa ruacas quimica.

(3) La ila istá reacindo a e prociso que aquecimento, le assim liberando vapor apos funê.la.

\begin{tabular}{|c|c|c|}
\hline \multirow[t]{4}{*}{ (9) } & tintura de cabilo & \& u' um processo quimice, pais \\
\hline & 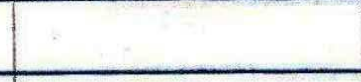 & - vidcal desse produte \\
\hline & & uo inidarnea de cev es mat \\
\hline & & - estado físico. \\
\hline \multicolumn{2}{|c|}{ ácule para Gerver } & - I reacōo fíbica \\
\hline & & poir nấ alturou, on criou \\
\hline & & um nove natual, wopnas \\
\hline & & dikerow vaper. \\
\hline
\end{tabular}

\begin{tabular}{|c|c|}
\hline fruta conservada. & $\rightarrow$ procerso hírico pansín osm \\
\hline por muinto terrupe. & alcemas partas quinucias, pois \\
\hline & u' p'seco por ter mudados a sua \\
\hline & Horna física, após ter fucado por \\
\hline & muito tempo em repoins poevrendo \\
\hline & - prouerso quimicio es ao mesmo \\
\hline & tempe o procurse proí̃o? \\
\hline
\end{tabular}




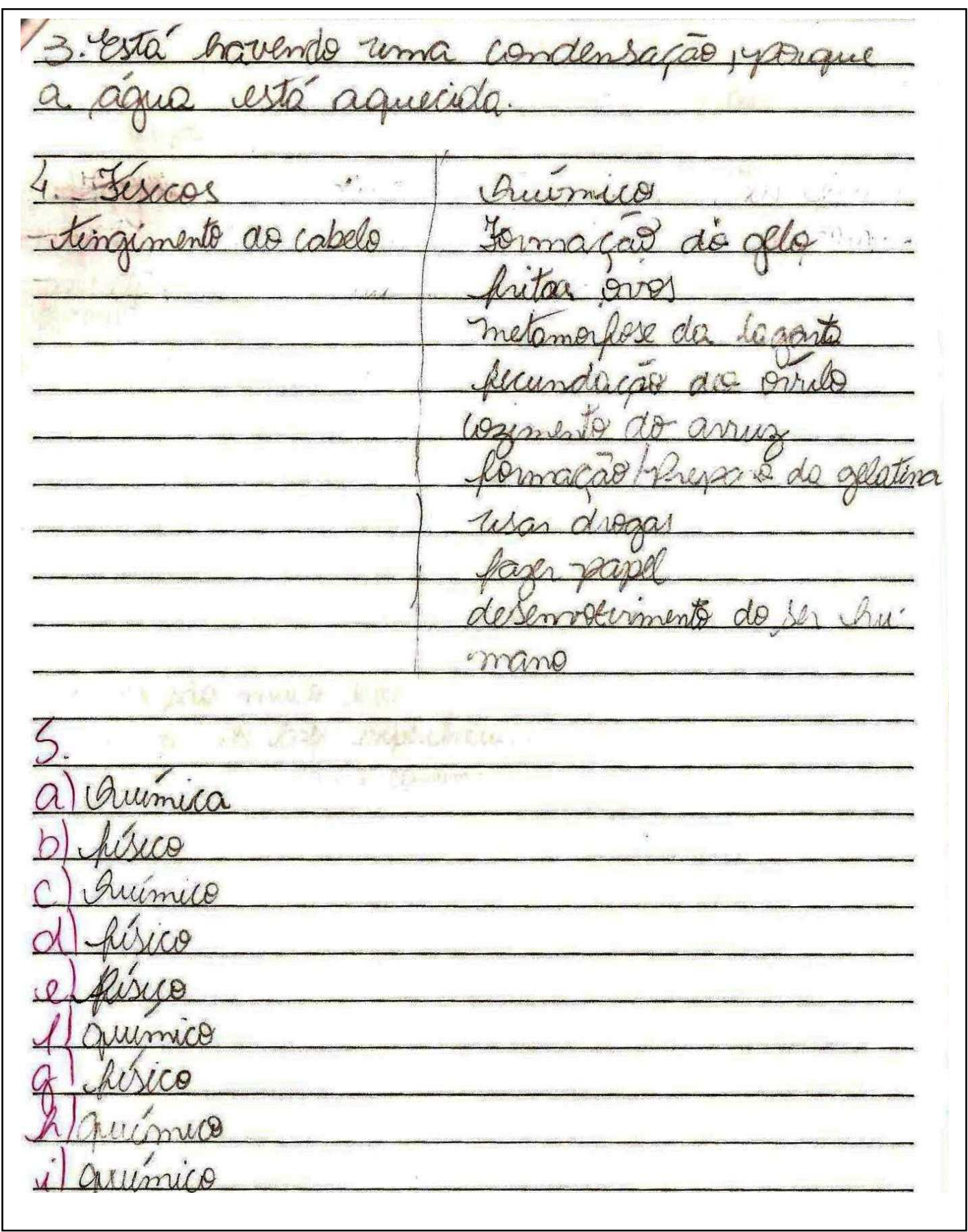

